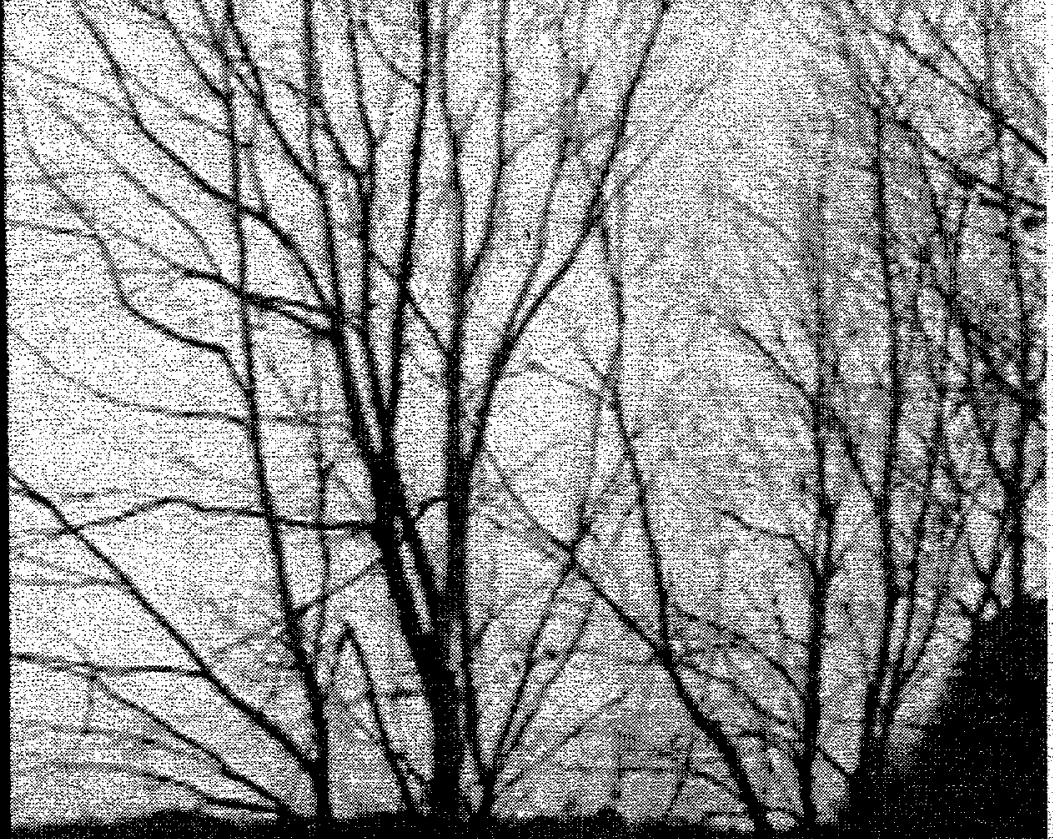

U.S. Department of Energy

\title{
Portsmouth
}

\author{
Annual \\ Environmental Report \\ for 1995
}




\begin{tabular}{lll}
\hline Current System & Systeme International & Conversion \\
\hline curie (Ci) & becquerel (Bq) & $1 \mathrm{Ci}=3.7 \times 10^{10} \mathrm{~Bq}$ \\
rad (radiation absorbed dose) & gray (Gy) & $1 \mathrm{rad}=0.01 \mathrm{~Gy}$ \\
rem (roentgen equivalent man) & sievert (Sv) & 1 rem $=0.01 \mathrm{~Sv}$ \\
\hline
\end{tabular}

Fractions and multiples of units

\begin{tabular}{cccccc}
\hline Multiple & Decimal equivalent & Prefix & Symbol & Report format \\
\hline $10^{6}$ & $1,000,000$ & mega- & kilo- & M & E +06 \\
$10^{3}$ & 1,000 & hecto- & k & h \\
$10^{2}$ & 100 & deka & h & E+03 \\
10 & 10 & deci- & da & E+01 \\
$10^{-1}$ & 0.1 & centi- & d & E-01 \\
$10^{-2}$ & 0.01 & milli- & c & E-02 \\
$10^{-3}$ & 0.001 & micro & m & E-03 \\
$10^{-6}$ & 0.000001 & nano & u & E-06 \\
$10^{-9}$ & 0.000000001 & pico- & n & E-09 \\
$10^{-12}$ & 0.000000000001 & fento- & p & E-12 \\
$10^{-15}$ & 0.000000000000001 & atto- & a & E-15 \\
$10^{-18}$ & 0.000000000000000001 & & E-18 \\
& & & & & \\
\hline
\end{tabular}

This report has been reproduced directly from the best available copy, and is available to DOE and DOE contractors from the Office of Scientific and Technical Information, P.O. Box 62, Oak Ridge, TN 37831; prices available from (423) 576-8401. It is available to the public from the National Technical Information Service, U.S. Department of Commerce, 5285 Port Royal Rd., Springfield, VA 22161.

On the Cover : A view of the X-611A Lime Sludge Lagoon Environmental Restoration Project. (PORTS Photo 96-041-93) 
POEF-LMES-85

\section{U.S. DEPARTMENT OF ENERGY PORTSMOUTH ANNUAL ENVIRONMENTAL REPORT FOR 1995}

Date Published: April 1997

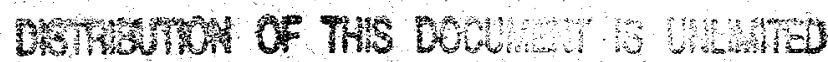

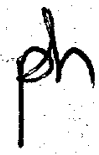

Prepared by

Environmental Compliance Division

Portsmouth Site

LOCKHEED MARTIN ENERGY SYSTEMS, INC.

P.O. Box 628

Piketon, Ohio 45661

for the

U.S. DEPARTMENT OF ENERGY

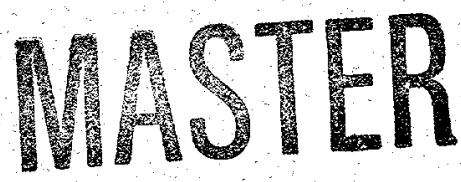
under contract no. DE-AC05-84OR21400 



\section{DISCLAMMER}

Portions of this document may be illegible in electronic image products. Images are produced from the best available original document. 


\section{DISCLAIMER}

This report was prepared as an account of work sponsored by an agency of the United States Government. Neither the United States Government nor any agency thereof, nor any of their employees, make any warranty, express or implied, or assumes any legal liability or responsibility for the accuracy, completeness, or usefulness of any information, apparatus, product, or process disclosed, or represents that its use would not infringe privately owned rights. Reference herein to any specific commercial product, process, or service by trade name, trademark, manufacturer, or otherwise does not necessarily constitute or imply its endorsement, recommendation, or favoring by the United States Government or any agency thereof. The views and opinions of authors expressed herein do not necessarily state or reflect those of the United States Government or any agency thereof. 


\section{Contents}

List of Figures

vii

List of Tables

ix

Executive Summary

$\mathbf{x i}$

Acronyms and Abbreviations

$\mathrm{xxi}$

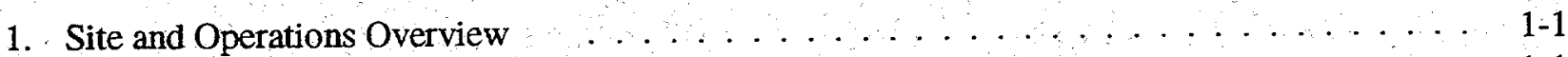

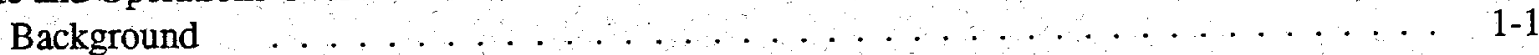

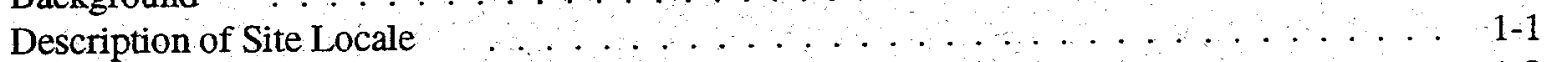

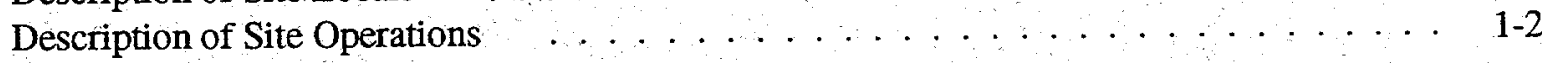

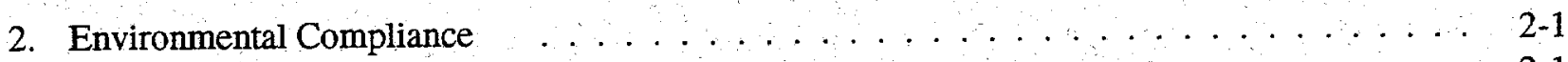

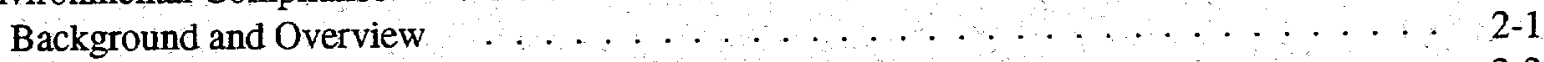

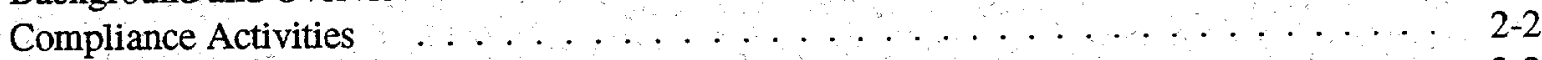

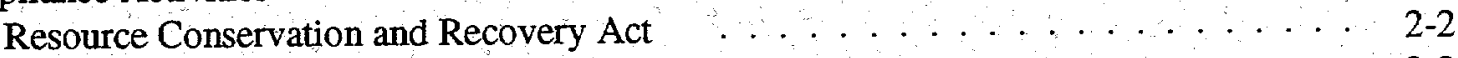

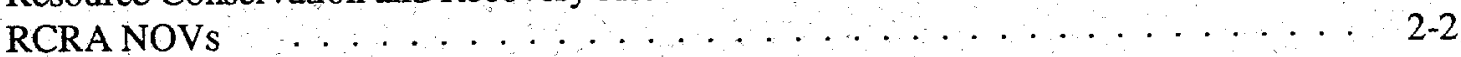

Ohio Consent Decree and USEPA Administrative Consent Order $\ldots \ldots \ldots \ldots$

Federal Facilities Compliance Act $\ldots \ldots \ldots \ldots \ldots \ldots \ldots \ldots$

Comprehensive Environmental Response, Compensation, and

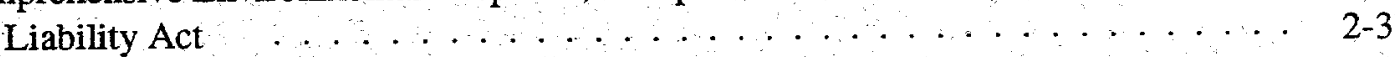

Emergency Planning and Community Right-To-Know Act $\quad \ldots \ldots \ldots \ldots$

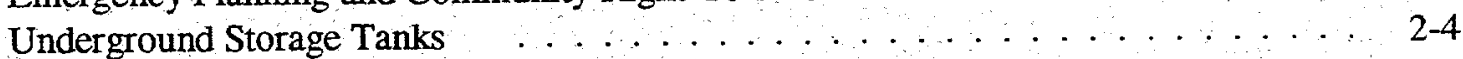

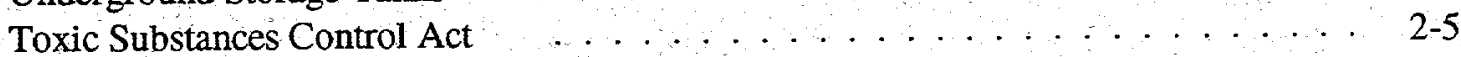

Federal Facilities Compliance Agreement $\quad \ldots \ldots \ldots \ldots \ldots \ldots \ldots$

Federal Insecticide, Fungicide, and Rodenticide Act $\ldots \ldots \ldots 2-6$

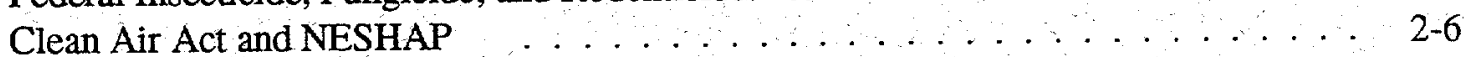

Clean Water Act $\quad \ldots \ldots \ldots \ldots \ldots \ldots \ldots \ldots \ldots \ldots \ldots \ldots$

National Environmental Policy Act $\quad \ldots \ldots \ldots \ldots \ldots . \ldots \ldots$

Other Environmental Acts and Federal Regulations $\quad \ldots \ldots \ldots \ldots \ldots$

Ohio Agreement in Principle $\quad \ldots \ldots \ldots \ldots \ldots \ldots \ldots \ldots \ldots \ldots$

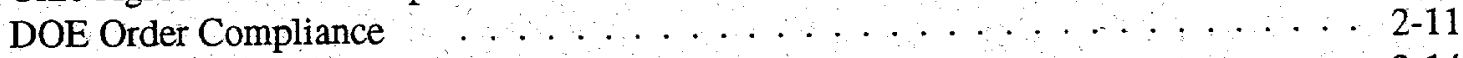

Occurrences Reported to Regulatory Agencies $\ldots \ldots \ldots \ldots \ldots$

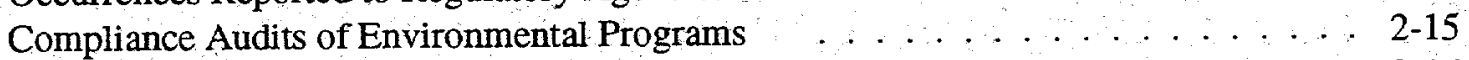

Environmental Permits $\quad \ldots \ldots \ldots \ldots \ldots \ldots \ldots \ldots \ldots \ldots \ldots \ldots \ldots \ldots \ldots$

Clean Air Act Permit Status $\quad \ldots \ldots \ldots \ldots \ldots \ldots \ldots \ldots$

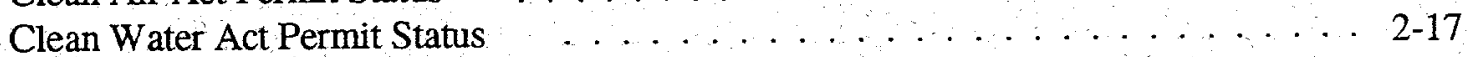

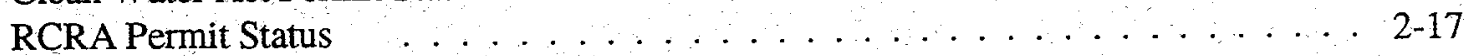

X-735 Industrial Solid Waste Landfill Permit Status $\quad \ldots \ldots \ldots \ldots \ldots$

3. Environmental Program Information $\ldots \ldots \ldots \ldots \ldots \ldots \ldots \ldots \ldots \ldots \ldots \ldots$

Environmental Monitoring Program $\quad \ldots \ldots \ldots \ldots \ldots \ldots \ldots \ldots \ldots \ldots \ldots \ldots \ldots \ldots$ 
Goals

Rationale

Environmental Monitoring Program Changes in $1995 \ldots \ldots \ldots$. . . . . . . . . . .

Environmental Quality

Waste Management Program

Environmental Restoration Program

Waste Minimization and Pollution Prevention Program

Environmental Training Program

Information Exchange Program

Public Awareness Program

Ohio Agreement in Principle

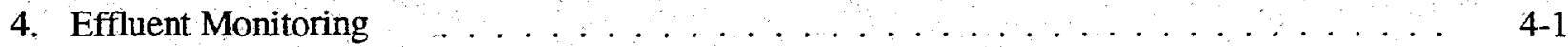

Introduction

Airborne Discharges

Radiological Airborne Discharges

Nonradiological Airborne Discharges

Liquid Discharges

Background

Radiological Liquid Discharges

Nonradiological Liquid Discharges

5. Dose

Introduction

Applicable Regulations

Radiological Regulations

Chemical Regulations

Dose Calculation

Radiological Dose Calculation

Chemical Dose Calculation

Dose Calculation Results

Radiological Dose Results

6. Groundwater

Introduction

Groundwater Hydrology

Geological and Hydrogeological Setting

Topography

Stratigraphy

Geologic History

Groundwater Hydrogeology

Uses of Groundwater in the Vicinity:

Applicable Monitoring Standards

State and Federal Laws and Regulations _ . . . . . . . . . . . . . $6-8$

DOE Orders

Ohio Consent Decree and USEPA Administrative Consent

Order 
Groundwater Monitoring at DOE/PORTS $\ldots \ldots \ldots \ldots \ldots \ldots \ldots \ldots$

Detection Monitoring . . . . . . . . . $6 \ldots \ldots \ldots .6 \ldots$

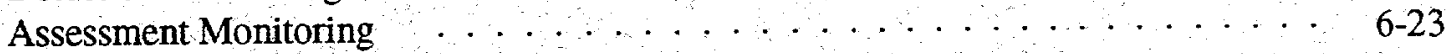

Groundwater Surveillance Monitoring $\ldots \ldots \ldots \ldots \ldots \ldots \ldots$

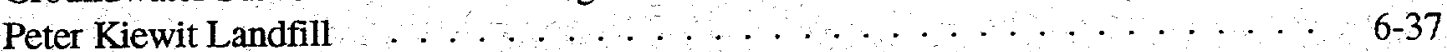

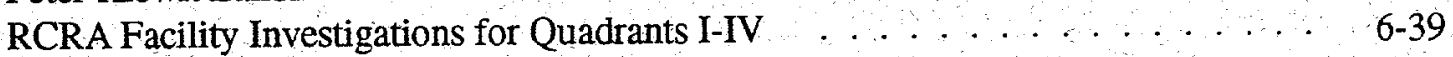

Groundwater Treatment Units $\ldots \ldots \ldots \ldots \ldots \ldots 6 . \ldots \ldots \ldots$

Background Sampling $\ldots \ldots \ldots \ldots \ldots \ldots \ldots \ldots \ldots \ldots \ldots$

Groundwater Monitoring Results $\ldots \ldots \ldots \ldots \ldots \ldots$

RCRA Units . . . . . . . . . . . . . . . . 644

Surface Water ....................... 6.50

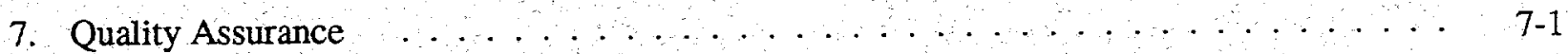

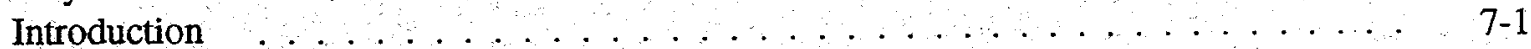

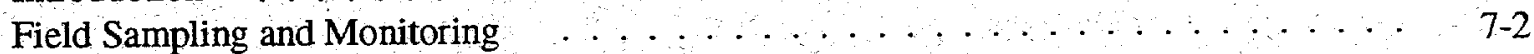

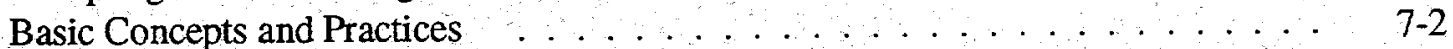

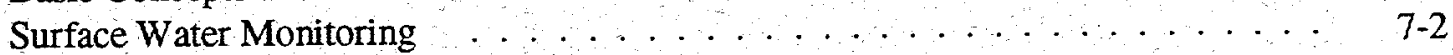

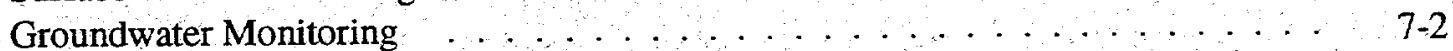

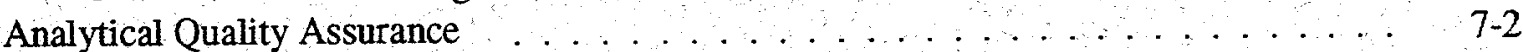

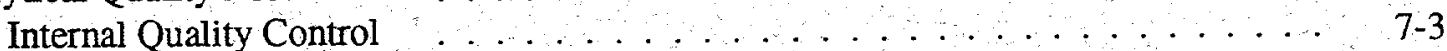

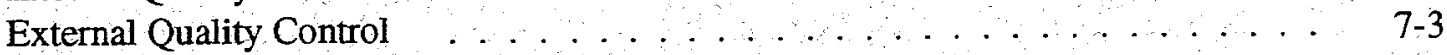

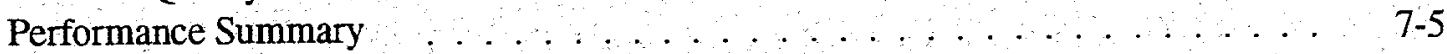

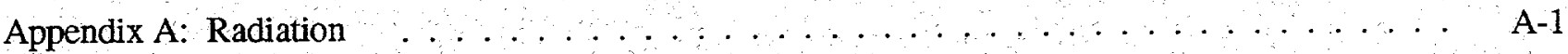

Appendix B: Environmental Permits $\quad \ldots \ldots \ldots \ldots \ldots \ldots \ldots \ldots \ldots \ldots \ldots$

Appendix C: Chemical Release Data $\ldots \ldots \ldots \ldots \ldots \ldots \ldots \ldots \ldots \ldots \ldots$

Appendix D: Radionuclide and Chemical Nomenclature $\ldots \ldots \ldots \ldots \ldots \ldots$

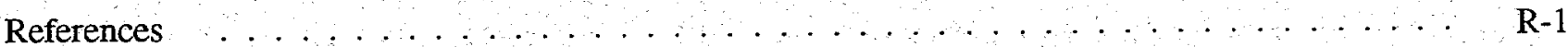

Glossary $\ldots \ldots \ldots \ldots \ldots \ldots \ldots \ldots \ldots \ldots \ldots \ldots \ldots \ldots \ldots \ldots \ldots \ldots \ldots \ldots \ldots \ldots \ldots$ 



\section{List of Figures}

Figure

Page

1 DOE/PORTS is one of two U.S. government-owned, contractor-managed uranium enrichment facilities in operation $\ldots \ldots \ldots \ldots \ldots$

$2 \quad$ Airborne radionuclides discharged at DOE/PORTS, $1991-1995 \ldots \ldots \ldots \ldots$

$3 \quad$ Waterborne radionuclides discharged at DOEJPORTS, $1991-1995 \ldots \ldots \ldots$ xiv

$4 \quad$ Maximum predicted individual EDEs from airborne radionuclides

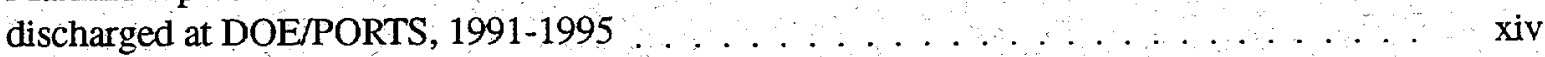

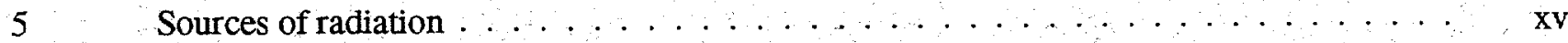

$6 \quad$ Average dose from terrestrial radiation in the United States $\ldots \ldots \ldots \ldots$

$7 \quad$ Comparison of dose from various common radiation sources $\ldots \ldots \ldots \ldots$ xvi

$1.1 \quad$ Location of DOE/PORTS within the state of Ohio $\ldots \ldots \ldots \ldots \ldots \ldots \ldots$

$1.2 \quad$ Location of DOE/PORTS in relation to the geographic region $\ldots \ldots \ldots \ldots \ldots$

4.1 Total curies of uranium discharged to air from DOE sources, $1991-1995 \ldots \ldots \ldots$

$4.2 \quad$ Total kilograms of uranium discharged to air from DOE sources, $1991-1995 \ldots \ldots \ldots$. . . . .

$4.3 \quad$ Total curies of technetium discharged to air from DOE sources, 1991-1995 . . . .

4.4 Major wastewater sources and systems at DOE/PORTS _ $\ldots \ldots \ldots \ldots \ldots$

$4.5 \quad$ NPDES water sampling locations at DOE/PORTS $\ldots \ldots \ldots \ldots \ldots \ldots \ldots$

4.6 Flow diagram for outfall $015(\mathrm{X}-624$ carbon filtration facility) $\ldots \ldots \ldots \ldots$

4.7 Flow diagram for outfalls 006,007 , and 008 (X-611A notth, middle,

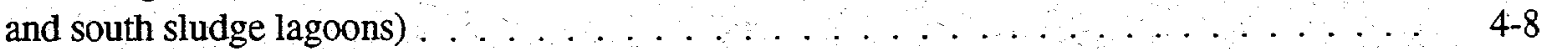

4.8 Flow diagram for outfalls 012 and 013 (X-2230M holding pond and

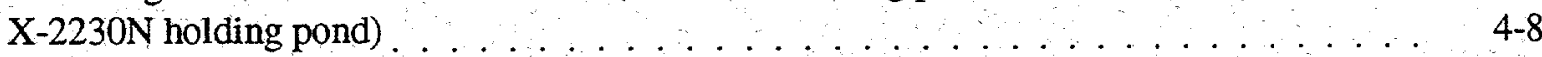

6.1 Typical monitoring well construction $\ldots \ldots \ldots \ldots \ldots \ldots \ldots \ldots \ldots \ldots \ldots \ldots \ldots \ldots$

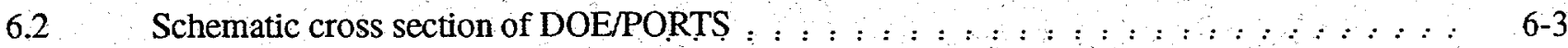


$6.3 \quad$ RCRA interim status land disposal unit locations at DOE/PORTS $\ldots \ldots \ldots \ldots$. . . . . . .

$6.4 \quad$ Solid waste land disposal unit locations at DOE/PORTS $\ldots \ldots \ldots \ldots$. . . . . . . . . .

$6.5 \quad X-735$ landfill monitoring well locations $\ldots \ldots \ldots \ldots \ldots \ldots \ldots \ldots \ldots \ldots$

$6.6 \quad \mathrm{X}-701 \mathrm{C}$ neutralization pit monitoring well locations, $1995 \ldots \ldots \ldots \ldots \ldots \ldots$

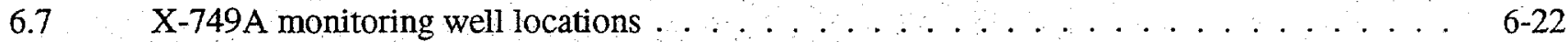

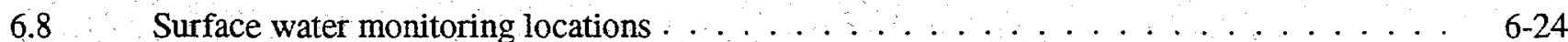

$6.9 \quad \mathrm{X}$-701B holding pond - extent of TCE concentration, $1995 \ldots \ldots \ldots \ldots$

$6.10 \quad \mathrm{X}-231 \mathrm{~B}$ southwest oil biodegradation plot monitoring well locations

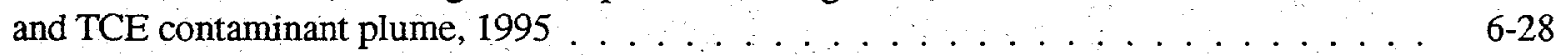

6.11 X-616 groundwater monitoring well locations - extent of dissolved

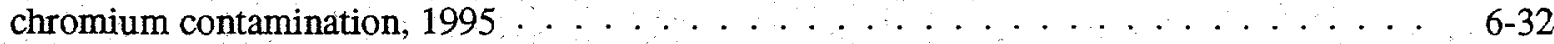

6.12 X-749 groundwater monitoring well locations -- extent of TCE

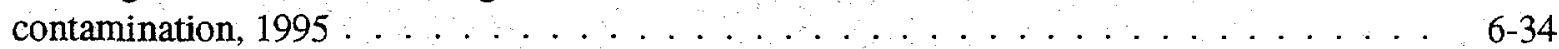

$6.13 \quad$ Exit-pathway monitoring locations at DOE/PORTS $\ldots \ldots \ldots \ldots \ldots$

$6.14 \quad$ Portsmouth off-site sampling locations $\ldots \ldots \ldots \ldots \ldots \ldots \ldots \ldots \ldots \ldots \ldots \ldots \ldots$

$6.15 \quad$ Baseline well monitoring locations at DOE/PORTS $\ldots \ldots \ldots \ldots$

$6.16 \quad$ RFI quadrants and associated drainages at DOE/PORTS $\ldots \ldots \ldots 6-42$

$6.17 \quad \mathrm{X}$-701B holding pond trends in TCE concentrations at selected wells . . . . . . $6-45$

$6.18 \quad \mathrm{X}-749$ contaminated materials disposal trends in TCE concentrations . . . . . . . $6-47$

$6.19 \quad \mathrm{X}-231 \mathrm{~B}$ southwest oil biodegradation plot trends in TCE concentrations . . . . . $6-48$

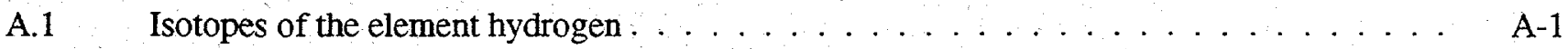

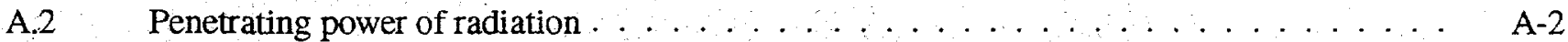

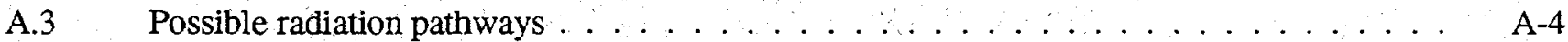




\section{List of Tables}

Table

Page

2.1 RCRA facility closure status of DOE/PORTS for $1995 \ldots \ldots \ldots \ldots \ldots$

2.2 Environmental audits and inspections at DOE/PORTS for $1995 \ldots \ldots \ldots$

2.3 DOE/PORTS environmental permits for $1995 \ldots \ldots \ldots \ldots \ldots \ldots \ldots$

4.1 Radionuclide releases to air from DOE activities at the Portsmouth site in $1995 \ldots$

6.1 Stratigraphy in the vicinity of DOE/PORTS

6.2 Analyte analysis required for groundwater monitoring at RCRA units, the industrial landfills, surface water locations, and the $\mathrm{X}-701 \mathrm{C}$ neutralization pit at DOE/PORTS .

7.1 Performance summary of the Portsmouth analytical laboratory external quality

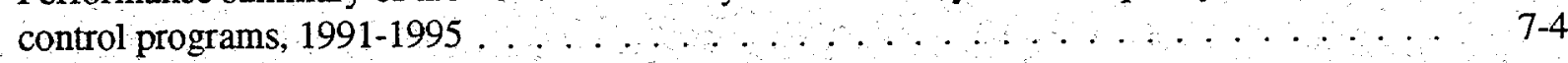

A.1 Comparison and description of various dose levels $\ldots \ldots \ldots \ldots \ldots \ldots$ A-6

B.1 DOEPORTS environmental permits $\ldots \ldots \ldots \ldots \ldots \ldots \ldots \ldots \ldots \ldots \ldots$

C.1 DOE/PORTS toxic chemical release inventory for $1995 \ldots \ldots \ldots \ldots \ldots \ldots$

D.1 Nomenclature and half-life for radionuclides $\ldots \ldots \ldots \ldots \ldots \ldots \ldots \ldots$

D. Nomenclature for elements and chemical constituents $\ldots \ldots \ldots \ldots \ldots \ldots \ldots$ 



\section{Executive Summary}

\section{ABOUT DOE/PORTS}

The Portsmouth plant is one of two U.S. Department of Energy (DOE)-owned, contractor-managed uranium enrichment facilities in operation (see Figure 1). As of July 1, 1993, responsibility for implementing environmental compliance at the facility was split between DOE, as site owner, and the United States Enrichment Corporation (USEC), a government-owned corporation formed by the National Energy Policy Act of 1992, to take over the nation's uranium enrichment business. The management contractor for DOE is Lockheed Martin Energy Systems (formerly Martin Marietta Energy Systems), which is responsible for waste management, environmental restoration, removal of highly enriched uranium (HEU), and operation of nonleased facilities at the Portsmouth Gaseous Diffusion Plant (DOE/PORTS). Lockheed Martin Utility Services (formerly Martin Marietta Utility Services) provides management services for USEC. The Nuclear Regulatory Commission is scheduled to assume direct oversight of USEC operations in 1997. Until then, DOE is providing oversight of nuclear safety and safeguards and security.

DOE/PORTS is located on about six square miles in Pike County, Ohio. The County has approximately 24,250 residents. The total population within 50 miles of the plant is about 900,000 .

The main process at the Portsmouth facility has been the separation of uranium isotopes through gaseous diffusion. Uranium is no longer enriched by DOE at DOE/PORTS. The uranium enrichment production operation facilities at the site are leased to USEC and are managed and operated by Lockheed Martin Utility Services.

PORTS PHOTO 94-286-2

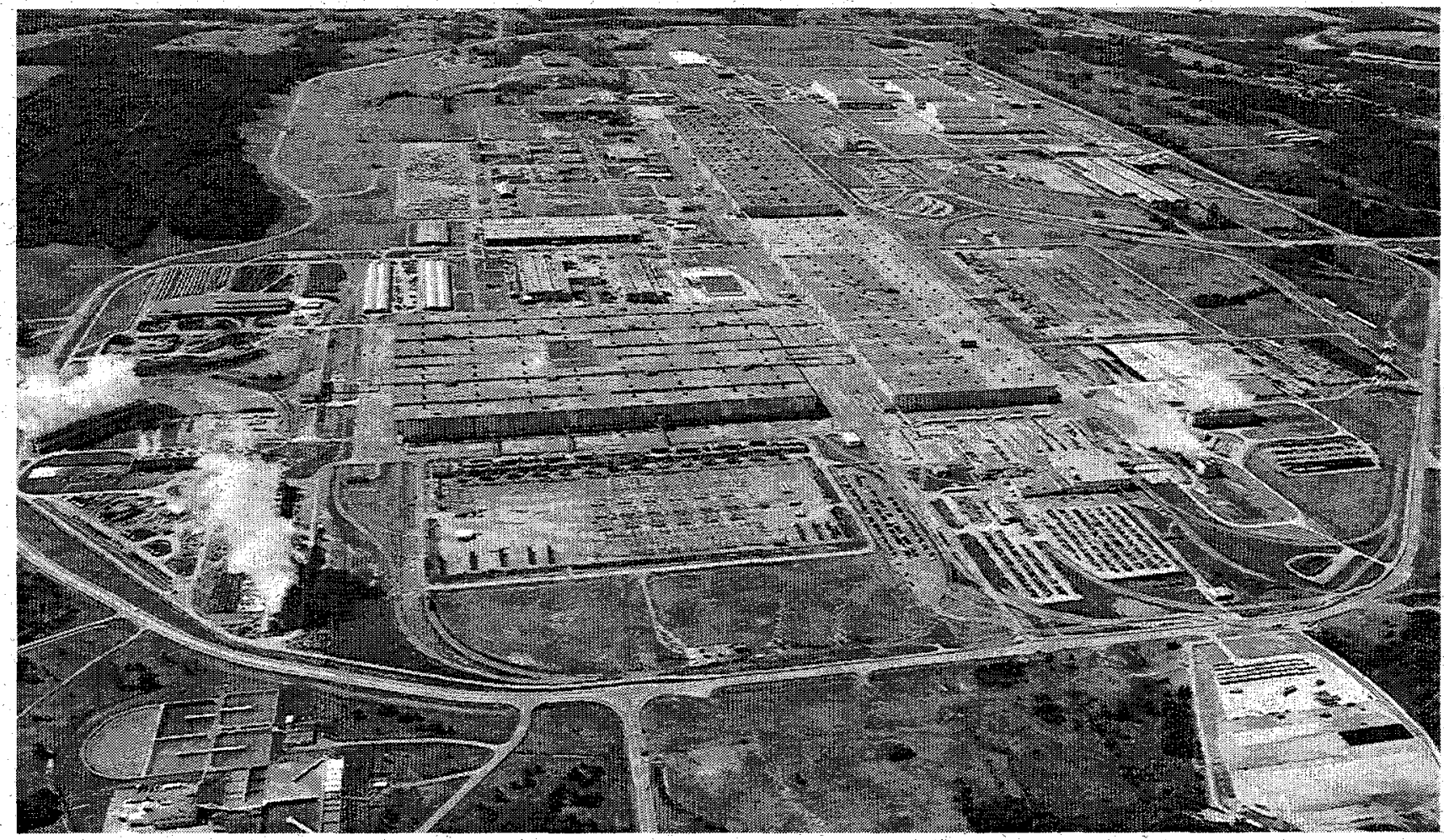

Fig. 1. DOE/PORTS is one of two U.S. government-owned, contractor-managed uranium enrichment facilities in operation. The other facility is in Paducah, Kentucky. 


\section{SCOPE AND PURPOSE}

This report summarizes the 1995 environmental monitoring of DOE activities at the Portsmouth Gaseous Diffusion Plant and its environs. This report consists of two separate documents: a discussion of compliance status, data, and environmental impacts (this document); and a volume of detailed data that is available on request. The objectives of this report are to

- report compliance status during 1995 ,

- provide information about the site and DOE operations,

- report 1995 monitoring data for the installation and its environs that may have been affected by DOE operations on the site,

- document information on input and assumptions used in calculations,

- provide trend analyses (where appropriate) to indicate increases and decreases in environmental impact, and

- provide general information on quality assurance for the environmental monitoring program for DOE operations.

\section{Compliance Status}

Several federal, state, and local agencies are responsible for enforcing environmental regulations at DOE/PORTS. As of July 1, 1993, responsibility for ensuring compliance was split between DOE, as site owner responsible for waste management, environmental restoration, removal of HEU, and operation of nonleased facilities, and USEC. The Nuclear Regulatory Commission (NRC) is scheduled to assume direct oversight of USEC operations in 1997. In the interim, DOE is providing oversight until the NRC assumes regulatory responsibility.

Although much progress has been made toward achieving full regulatory compliance at DOE/ PORTS, much remains to be accomplished. Ongoing self-assessments of compliance status continue to identify environmental issues. These issues are discussed frequently with regulatory agencies to ensure that appropriate actions are taken to achieve compliance.

The Ohio Hazardous Waste Facility Board issued a Resource Conservation and Recovery Act (RCRA) Part B permit to DOE allowing storage of hazardous waste in buildings X-7725 and X-326. To supplement the site RCRA Facility Investigation (RFI) report, DOE met the regulatory milestone for submittal of the air RFI report to the U.S. Environmental Protection Agency (USEPA) and Ohio Environmental Protection Agency (Ohio EPA). No RCRA Notices of Violation (NOV) were issued to DOE by the Ohio EPA in 1995. There are currently five outstanding violations from previous audits: (1) failure to make hazardous waste determinations regarding depleted uranium hexafluoride cylinders and lithium hydroxide containers stored at DOE/PORTS; (2) storage of hazardous waste in the X-700 tank 7 for more than 90 days; (3) failure to conduct tank assessments on the X-700 tanks 6,7 , and 8 and the X-740 and X-750 tanks; (4) lack of secondary containment for five tanks listed in item 3; and (5) lack of a hazardous waste permit for the X-700 tank 7. Efforts are under way to negotiate a director's Findings and Orders with the Ohio EPA to address the first item, and to negotiate a Judicial Order with Ohio EPA for the other four violations. In the meantime, the $X-700$ tanks 6,7 and 8 and the $X-740$ and X-750 tanks have been closed.

In 1995 the Ohio EPA issued a director's Final Findings and Orders for DOE/PORTS treatment plan for mixed wastes. This plan was previously submitted as required by the 1992 Federal Facilities Compliance Act. 
In 1995 DOE/PORTS reported nine occurrences to regulatory agencies. Of these, seven were National Pollutant Discharge Elimination System (NPDES) occurrences, involving 11 permit exceedences reported to the Ohio EPA. Another occurrence involved the release of PCB rinse water, and the last documented the release of a small amount of chlorine trifluoride gas. No violations of air permit or National Emission Standards for Hazardous Air Pollutants (NESHAP) limits occurred in 1995 at DOE/PORTS.

\section{RADIONUCLIDE AND CHEMICAL RELEASES}

Environmental monitoring systems at Portsmouth include emission monitoring networks for air and surface water discharges. Specific emission monitoring networks include a network of three continuous vent samplers on the major radionuclide and fluoride emission sources and a network of nine sampling locations for plant discharges to local surface waters.

\section{Airborne Releases}

The release of pollutants into the atmosphere from numerous point and non-point sources at DOE/ PORTS is regulated by permits from the state of Ohio and the USEPA. These pollutants include standard industrial pollutants such as gaseous fluorides, gasoline and diesel fuel vapors, cleaning solvent vapors, and process coolants (chlorofluorocarbons), as well as small amounts of radionuclides. Airborne radionuclides are considered the main source of any radiation dose that might be received by the public from plant operations.

A total of $0.0343 \mathrm{Ci}\left(1.22 \times 10^{9} \mathrm{~Bq}\right)$ of radionuclides was released to the air in $1995,71.2 \%$ of which was technetium- 99 $\left.{ }^{99} \mathrm{Tc}\right)$, a weak beta emitter, and $28.8 \%$ of which consisted of uranium isotopes, all alpha emitters. The remaining emissions consisted of the short-lived uranium daughters. The five-year trend for airborne radionuclide emissions is shown in Figure 2.

Historically, uranium has accounted for 75 to almost $90 \%$ of the public dose from Portsmouth site emissions. Consequently, the

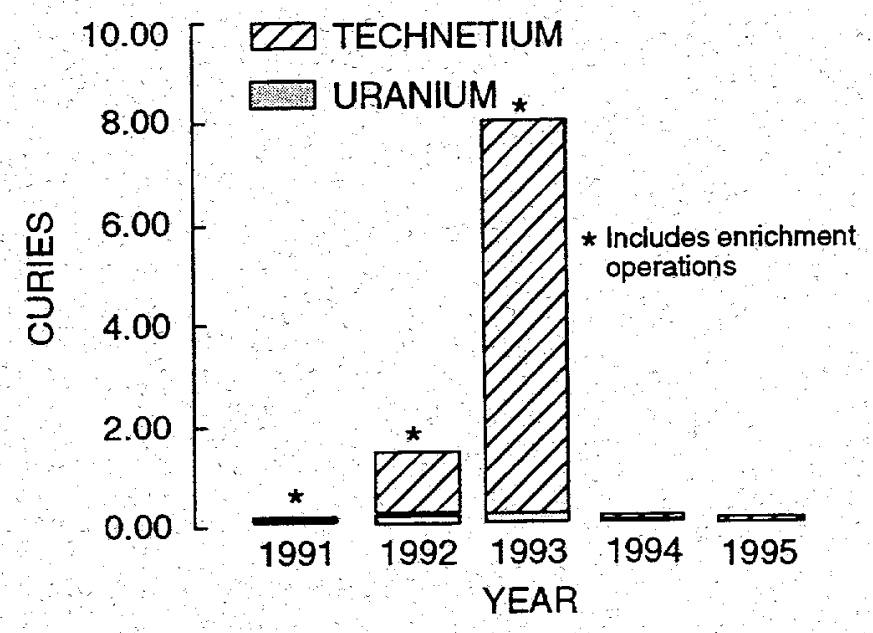

Fig. 2. Airborne radionuclides discharged at DOE/PORTS, 1991-1995. emission control systems on the cascade are optimized to reduce uranium emissions first and technetium emissions second. For the future, it is expected that mass emissions (kilograms) of uranium will remain about the same as levels seen from 1991 through 1995, but that the activity emissions (curies) of uranium should decrease after 1994 because of the absence of highly-enriched uranium in the emissions. 


\section{Waterborne Releases}

Treated effluents discharge to surface streams that pass through the reservation or directly to the Scioto River. Nonradiological plant-site liquid effluents related to DOE operations are regulated by the

NPDES and are routinely monitored. Radiological

EX SUM-F3-H2O-RAD.FH4

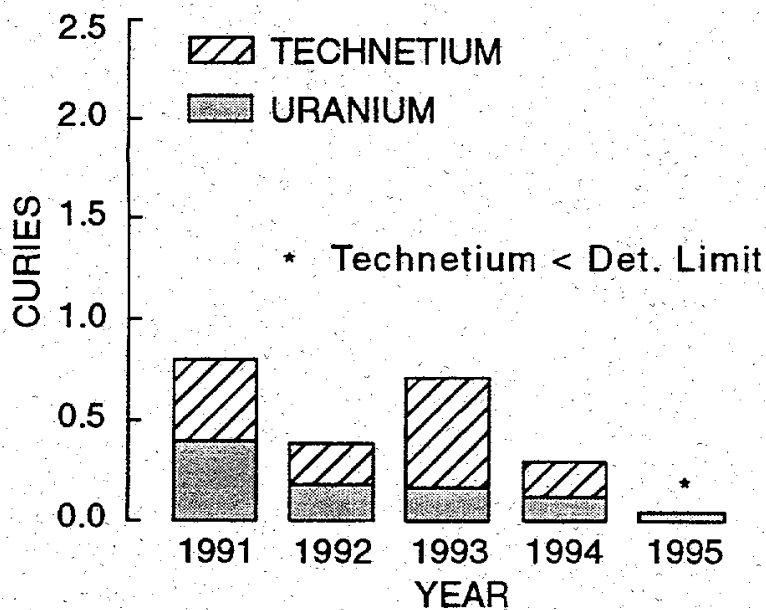

Fig. 3. Waterborne radionuclides discharged at DOE/PORTS, 1991-1995. analyses are also performed at NPDES sampling locations.

There are five radionuclides present in Portsmouth site releases that must be accounted for in the source term and dose assessment. Four of these are isotopes of uranium $\left({ }^{234} \mathrm{U},{ }^{235} \mathrm{U},{ }^{236} \mathrm{U}\right.$, and $\left.{ }^{238} \mathrm{U}\right)$ and the fifth is ${ }^{99} \mathrm{Tc}$. In addition, DOE/PORTS also accounts for three short-lived uranium daughters $\left({ }^{234} \mathrm{Th},{ }^{234 \mathrm{~m}} \mathrm{~Pa}\right.$, and ${ }^{231} \mathrm{Th}$ ), which are obviously present but do not add any significant contribution to the public dose. All of the uranium isotopes are alpha emitters; technetium is a weak beta emitter. The three uranium daughters are all beta or beta-gamma emitters.

A total of $0.002 \mathrm{Ci}\left(7.1 \times 10^{7} \mathrm{~Bq}\right)$ of radionuclides was released to surface water in 1995, essentially all of which was uranium isotopes. Technetium contamination was not detected in water samples

during 1995. This represents a decrease in uranium and technetium emissions from 1994. The five-year trend for waterborne radionuclide releases is shown in Figure 3. Total radiological releases to surface waters were well below all applicable USEPA and DOE standards.

Nonradiological releases to surface waters are best summarized by the extent of compliance with the plant NPDES permit limits. The NPDES compliance rate for those outfalls that are DOE's responsibility was $97.0 \%$ for 1995.

\section{RADIATION DOSE TO THE PUBLIC}

The calculated maximum potential 50-year committed effective dose equivalent (CEDE) to any individual from DOE/PORTS operations during 1995 was 0.13 mrem/year, much lower than the applicable USEPA standard of $10 \mathrm{mrem} / \mathrm{year}$ from National Emission Standards for Hazardous Air Pollutants and the DOE standard of $100 \mathrm{mrem} / \mathrm{year}$ from all sources. A comparison of maximum potential CEDEs resulting from airborne emissions during the last five

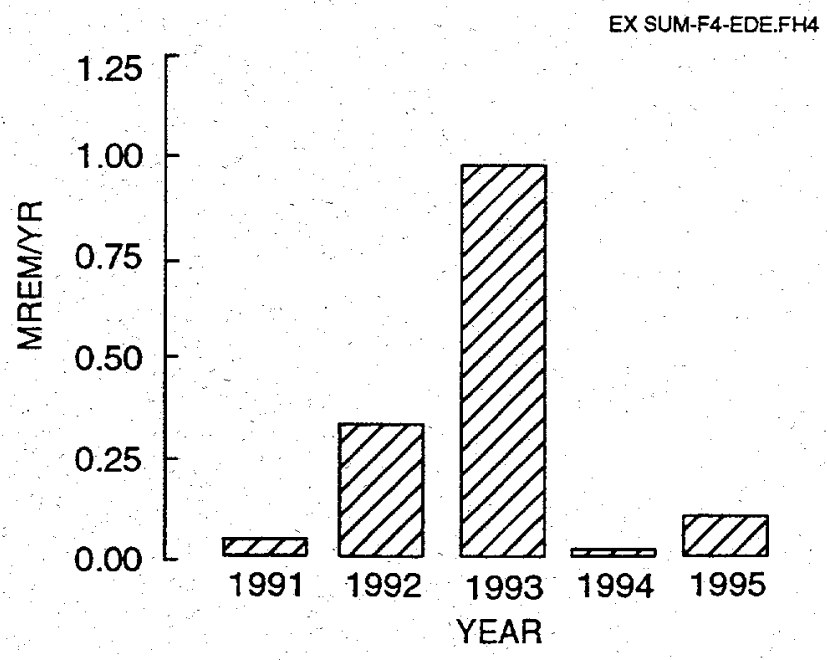

Fig. 4. Maximum predicted individual EDEs from airborne radionuclides discharged at DOE/PORTS, 1991-1995. 
years is shown in Figure 4. The calculated population dose (collective EDE) from airborne radionuclides was 0.02 person-rem/year to the nearest community (Piketon) and 1.2 person-rem/year to the total population within $80 \mathrm{~km}$ ( 50 miles) of the site. None of the potential doses calculated resulting from DOE/PORTS operations is significant to public health.

\section{Comparison of Dose Levels}

The dose received by a given individual can vary widely from year to year depending on numerous factors. The average individual in the United States receives a dose from natural exposure that is more than 200 times higher than he or she receives from nuclear industry operations (see Figure 5).

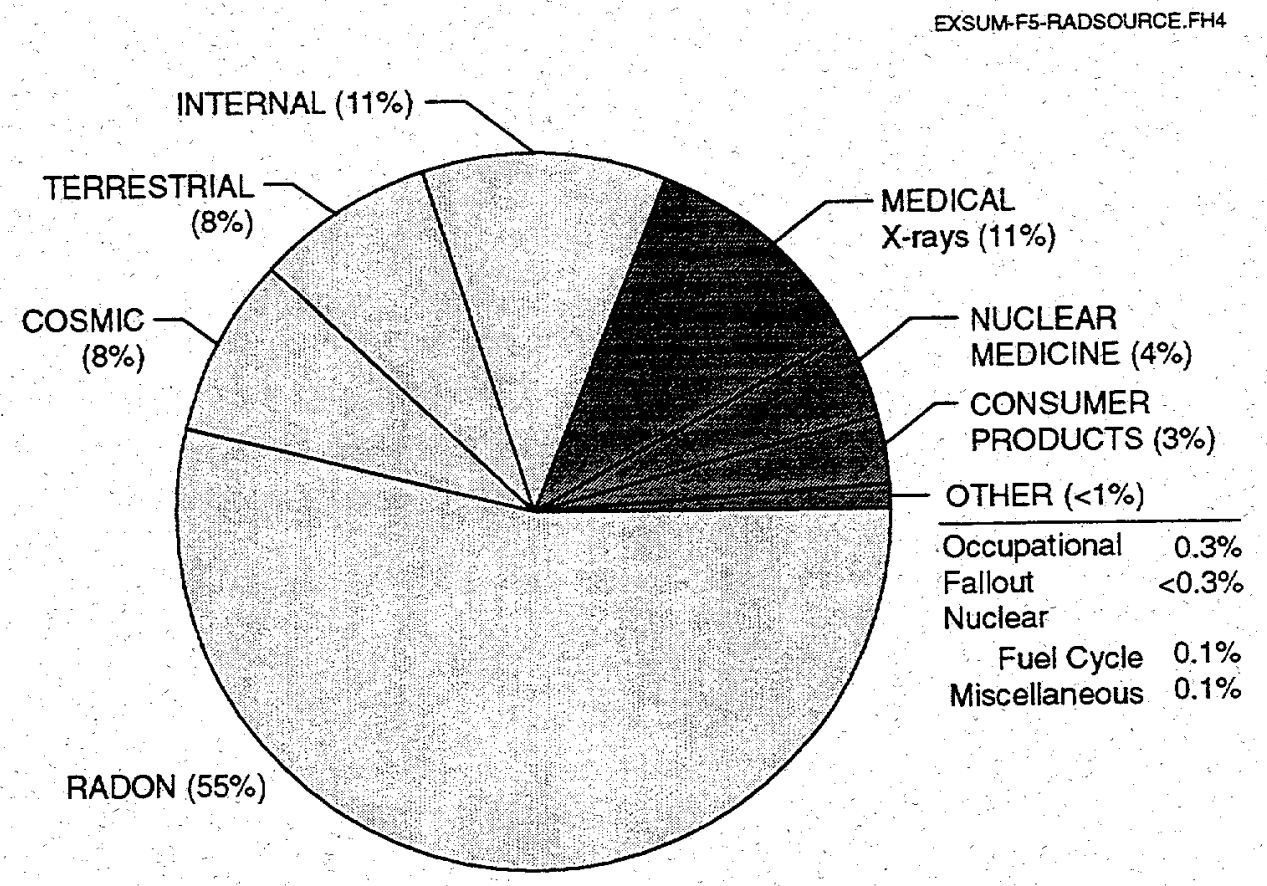

NATURAL $(82 \%)$

HUMAN MADE (18\%)

Fig. 5. Sources of radiation.

The average dose caused by background radiation also varies widely. In the United States, the average is about $300 \mathrm{mrem}$ per year; however, some people in other parts of the world receive a dose more than four times this amount. For example, in some areas of Brazil the dose to inhabitants can be more than 2000 mrem per year from background radiation. These variations are caused by several factors, most notably the type and amount of radionuclides in the soil (see Figure 6).

This diversity in background radiation, not human-made radiation, is responsible for the large differences in the dose to average individuals. Because people living in areas with high levels of background 


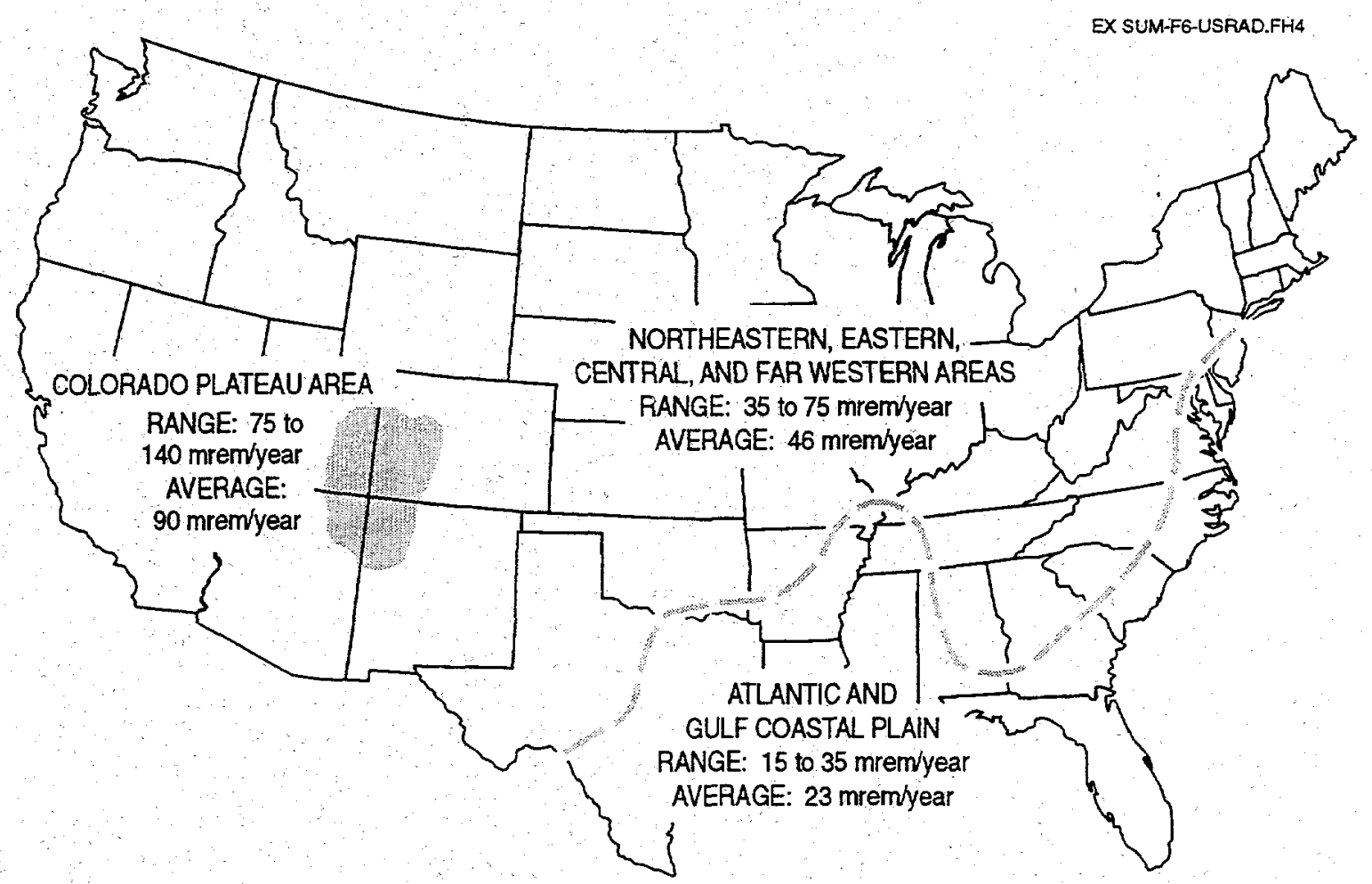

Fig. 6. Average dose from terrestrial radiation in the United States.

radiation do so without proven harm, it is assumed by most in the scientific community that the extremely small variations in dose caused by DOE/PORTS releases have inconsequential, if any, effect on humans. See Figure 7 for a comparison of various dose levels.

EX SUM F7-COMPDOSE.FHA

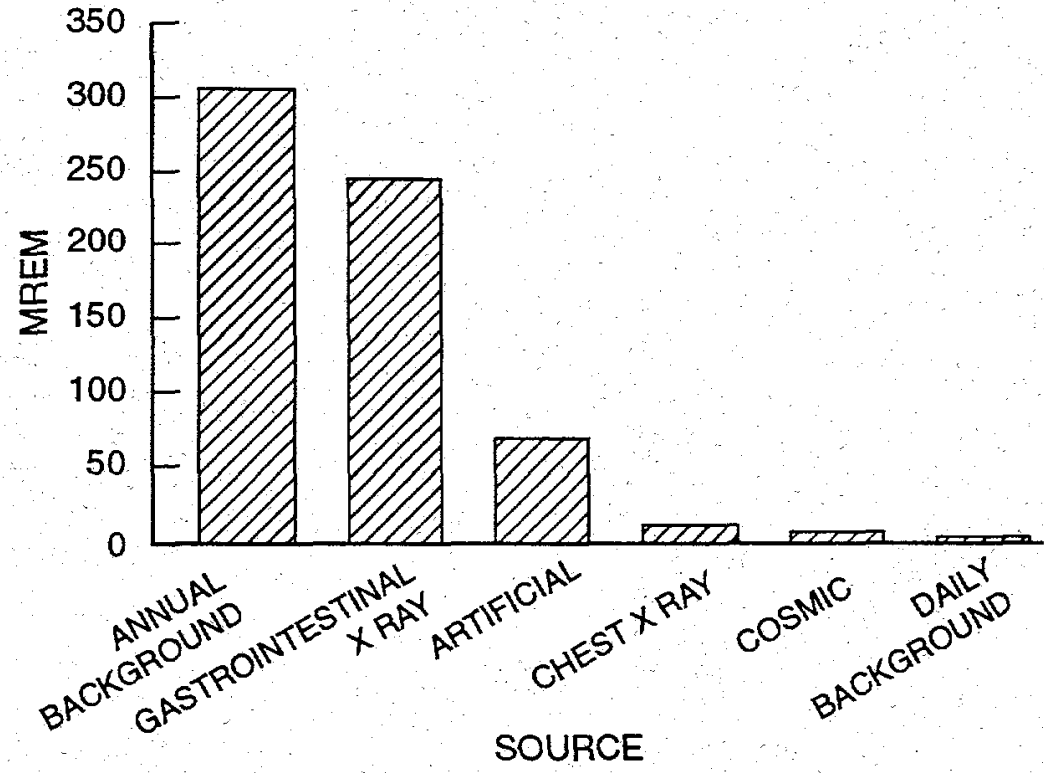

Fig. 7. Comparison of dose from various common radiation sources.
Everyone who works at DOE/PORTS remains committed to working safely, with regard to each other, the public, and the environment. This goal will be accomplished by keeping emissions as low as reasonably achievable, enhancing the strict safety controls that are already in place, and by using state-of-the-art technology to complete environmental remediation projects in the most cost-effective and efficient manner possible. 


\section{GROUNDWATER MONITORING}

The groundwater monitoring program at DOE/PORTS includes assessment monitoring and surface water monitoring associated with four RCRA land disposal units, detection monitoring associated with a sanitary landfill and a neutralization pit, and off-site monitoring of residential water sources (i.e., cisterns, springs, and wells).

The RCRA assessment monitoring program is based on results of a groundwater quality assessment completed in 1989 (Groundwater Quality Assessment of Four RCRA Units) and approved closure/post closure plans. Routine monitoring for a list of approved analytes is accomplished by sampling wells installed in the Gallia sand and the Berea sandstone. Sampling locations include 27 wells at the X-701B surface impoundment, 29 wells at the $X-749$ landfill, 15 wells at the X-616 chromium sludge surface impoundments, and 15 wells at the $\mathrm{X}-231 \mathrm{~B}$ land treatment area. In addition, points of groundwater discharge to surface water associated with these units are monitored at Little Beaver Creek, Big Run Creek, the southwest drainage ditch, the west drainage ditch, and the north holding pond.

Detection monitoring at the X-735 RCRA landfill is accomplished by sampling 13 groundwater monitoring wells on the perimeter of the landfill. Detection monitoring is also conducted at three wells surrounding the $\mathrm{X}-701 \mathrm{C}$ neutralization pit.

The RCRA facility investigations for Quadrants I through IV were completed in accordance with the requirements and schedules specified in the consent decree issued by the State of Ohio on August 29, 1989, and with the RCRA, Section 3008(h), Administrative Consent Order issued by USEPA Region V in 1989 and updated on August 11, 1994. During the RCRA facility investigations, two new groundwater plumes contaminated with volatile organic compounds were delineated: the Quadrant I investigative area (near the X-710 laboratory) and the Quadrant II area (near the X-700 chemical cleaning facility and the X-705 decontamination buildings).

The primary groundwater contaminant is trichloroethene (TCE) and its breakdown compounds. The drinking water maximum contaminant level (MCL) for TCE is $5 \mu \mathrm{g} / \mathrm{L}$; this $\mathrm{MCL}$ is exceeded at each of the plumes. The maximum TCE values for each plume are

- X-701B surface impoundment $-487,000 \mu \mathrm{g} / \mathrm{L}(1995)$,

- X-749 landfill $-5,100 \mu \mathrm{g} / \mathrm{L}(1995)$

- X-231B land treatment area-1,970 $\mu \mathrm{g} / \mathrm{L}(1995)$,

- Quadrant I investigative area-1,600 $\mu \mathrm{g} / \mathrm{L}$ (RFI, Phase I [1990] and Phase II [1992-93]),

- Quadrant II investigative area-3,700 $\mathrm{g} / \mathrm{L}$ (RFI, Phase I [1990] and Phase II [1992-93])

\section{QUALITY ASSURANCE AND QUALITY CONTROL}

When monitoring releases and measuring radiation in the environment; the reliability of the data is of the utmost importance. To ensure that the monitoring and measurement results are accurate, DOE/PORTS has a quality assurance and quality control program that is based on guidelines from the USEPA, the American Society for Testing and Materials, and other federal and state agencies. Portsmouth staff administer numerous quality control programs to ensure reliability of the data on a day-to-day basis. DOE/PORTS also participates actively in quality control programs administered by agencies outside the site, such as the USEPA and the National Institute of Occupational Safety and Health. These agencies prepare and distribute test samples for participating laboratories to analyze. The agencies then compile and evaluate the results and report to each laboratory on the accuracy of that laboratory's analyses. In 1995 the Portsmouth laboratory performed over 2,000 external control measurements, with $98.1 \%$ of the results being acceptable. 


\section{RESTORING THE ENVIRONMENT AND MANAGING WASTE}

Environmental restoration and waste management activities are carried out to protect the local population, improve the quality of the environment, and comply with federal and state regulations.

- Environmental restoration is the cleanup of wastes in the environment that originated from activities on the reservation.

- Waste management is the control of wastes, including their destruction or permanent storage.

\section{Environmental Restoration}

Environmental restoration is the process of cleaning up inactive waste sites and facilities to ensure that risks to human health and the environment are either eliminated or reduced to safe levels. DOE established the Environmental Restoration Program to find, analyze, and correct site contamination problems as quickly and inexpensively as possible. This task may be accomplished by removing, stabilizing, or treating hazardous substances. The federal law that addresses the restoration of inactive waste sites is the Resource Conservation and Recovery Act (or RCRA). This legislation includes identification of waste sites with the need for cleanup because of increased risk to public health or the environment. The DOE/PORTS Environmental Restoration Program was developed in 1989 and was granted an initial budget of 13.8 million dollars. Since then, annual program expenditures have grown to 50 to 60 million dollars.

\section{Waste Management}

The DOE/PORTS Waste Management Program directs the safe storage, treatment, and disposal of waste generated from operations and from environmental restoration projects. The main goal is to ensure that waste materials do not migrate into the environment.

Waste management requirements are varied and often complex because of the variety of wastes generated by DOE/PORTS activities. DOE orders and Ohio EPA, USEPA, and Ohio Department of Health regulations must be satisfied to ensure compliance of waste management activities. Supplemental policies have been implemented for management of radioactive, hazardous (chemical), and mixed (radioactive and hazardous) wastes. These policies include

- minimizing wastes;

- characterizing and certifying wastes before they are stored, processed, treated, or disposed of; and

- pursuing volume reduction and use of on-site storage when safe and cost-effective until a final disposal option is identified.

\section{OTHER ENVIRONMENTAL PROGRAMS AND ISSUES}

\section{Ecological Risk Assessment}

In the summer and fall of 1993, DOE initiated the preparation of a baseline ecological risk assessment for DOE/PORTS, including a wetland survey, a threatened and endangered plant survey, a threatened and endangered animal survey, and a bat survey. The wetland survey identified a number of areas considered to be wetland or emergent wetland; these areas were delineated and mapped in April 1994. The threatened and 
endangered plant survey and the bat survey were completed in the fall of 1994. Endangered animal survey results indicated the presence of several state-listed and possibly one federally listed threatened and endangered species within the reservation boundary. The final reports were submitted to DOE, the USEPA, and the Ohio EPA.

\section{COMMUNITY PARTICIPATION}

A comprehensive community relations and public participation program on the DOE Program has been established since early 1990 . The purpose of the program is to conduct a proactive public involvement program, with outreach components, to foster a spirit of openness and credibility among local citizens and various segments of the public. The program is also geared to provide the public with opportunities to become involved in decisions affecting environmental issues at the site:

DOE opened a public Environmental Information Center in February 1993 in an effort to provide public access to all documents used to drive decisions on remedial actions being taken at the plant. The information center has a full-time staff and is located about 10 miles north of the plant at 505 West Emmitt Avenue, Suite 3, Waverly, Ohio 45690. The center's hours are 10 a.m. to 4 p.m., Monday, Tuesday, Wednesday, and Friday, and 9 a.m. to 12 p.m. on Thursday, or after hours by appointment (614-947-5093).

A group of about 45 key stakeholders, composed of elected officials, community leaders, environmentalists, and other individuals who have expressed an interest in the DOE Program, is targeted for information and input on current activities and those actions under consideration at the plant site. Semiannual public update meetings are also held, as well as public workshops on specific topics to keep the public informed and to receive their comments and questions. Periodically, fact sheets about major projects are written for the public, and semiannual newsletters are printed and distributed to more than 4000 recipients, including the community relations mailing list, neighbors within two-miles of the plant site, and all plant site employees and retirees.

Points of contact have been established for the public to obtain information or direct questions regarding the DOE Program. The deputy site manager for DOE is the primary point of contact at $614-897$ 5510. The Lockheed Martin Energy Systems site manager and the Public Affairs manager also provide information on the program.

\section{REFERENCE}

Geraghty and Miller. 1989. Groundwater Quality Assessment of Four RCRA Units. Dublin, Ohio. 



\section{Acronyms and Abbreviations}

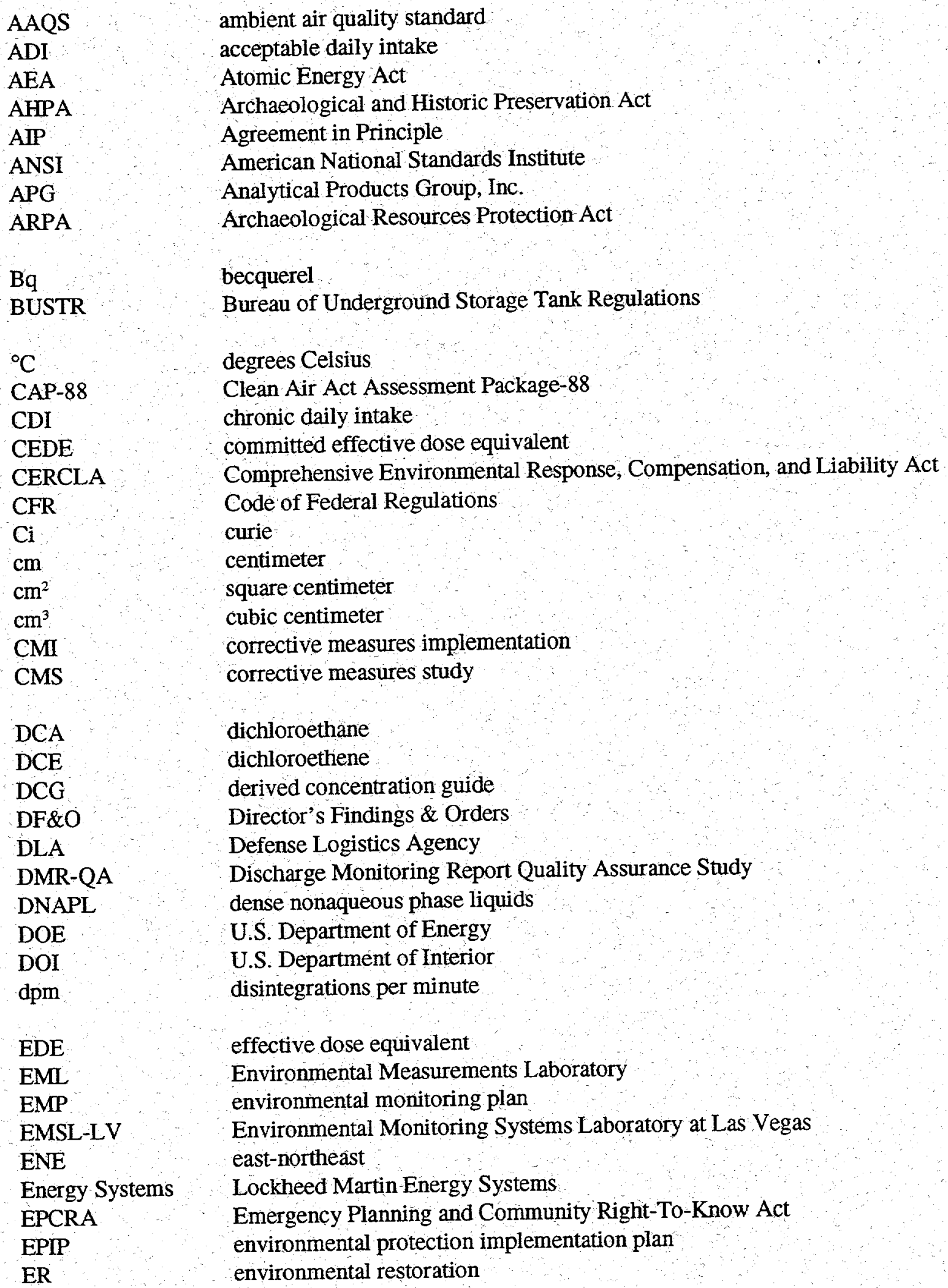


${ }^{\circ} \mathrm{F}$

FERC

FFCA

FFCact

Fm.

$\mathrm{ft}$

$\mathrm{ft}^{3}$

$\mathrm{g}$

gal

GCEP

GWPP

GWPPMP

GWPS

GWQA

HASA

HEU

$\mathrm{HF}$

HSWA

IRM

in.

ISW

$\mathrm{kg}$

$\mathrm{km}$

$\mathrm{km}^{2}$

L

Ib

LDR

$\mathrm{LiF}$

$\mathrm{LiOH}$

LLW

m

$\mathrm{m}^{2}$

$\mathrm{m}^{3}$

MAPEP

MCL

$\mathrm{mg}$

Mgd

MLd

$\mu \mathrm{Ci}$ degrees Fahrenheit

Federal Energy Regulatory Commission

federal facilities compliance agreement

Federal Facilities Compliance Act

formation

foot

cubic foot

gram

gallon

Gas Centrifuge Enrichment"Plant

groundwater protection program

groundwater protection program management plan

groundwater protection standard

groundwater quality assessment

high-assay sampling area

highly enriched uranium

hydrogen fluoride

Hazardous and Solid Waste Amendments of 1984

interim remedial measure

inch

industrial solid waste

kilogram

kilometer

square kilometer

liter

pound

land disposal restriction

lithium fluoride

lithium hydroxide

low-level waste

meter

square meter

cubic meter

Mixed Analyte Performance Evaluation Program

maximum contaminant level

milligram

million gallons per day

million liters per day

microcurie 
$\mu \mathrm{g}$

$\mu \mathrm{m}$

$\mu \mathrm{rad}$

mile $^{2}$

$\mathrm{mL}$

$\mathrm{mm}$.

mrem

MSDS

MSR

NEPA

NESHAP

NGVD

NIOSH

NIST.

NOV

NPDES

NRC

OAC

OANG

ODH

Ohio EMA

Ohio EPA

$\mathrm{Pa}$

PA

PCB

pCi

PET

$\mathrm{ppb}$.

ppm

PTI

PTO

QA

QC

qt

RCRA

RCW

REIRS

RFI

RQ

RW microgram

micron

microrad

square mile

milliliter

millimeter

millirem

material safety data sheet

maintenance service request

National Environmental Policy Act

National Emission Standards for Hazardous Air Pollutants

national geodetic vertical datum of 1929

National Institute for Occupational Safety and Health

National Institute for Standards and Technology

notice of violation

National Pollutant Discharge Elimination System

Nuclear Regulatory Commission

Ohio Administrative Code

Ohio Army National Guard

Ohio Department of Health

Ohio Emergency Management Agency

Ohio Environmental Protection Agency

protactinium

programmatic agreement

polychlorinated biphenyl

picocurie

Proficiency Environmental Testing Program

part per billion

part per million

permit to install

permit to operate

quality assurance

quality control

quart

Resource Conservation and Recovery Act

recirculating cooling water

Radiation Exposure Information Reporting System

RCRA facility investigation

reportable quantity

routine water 
SARA

SHPO

SWMU

Tc

TCA

TCE

TCL/TAL

TEDE

Th

TLD

TOC

TSCA

TSS

U

$\mathrm{UF}_{6}$

USEC

USEPA

UST

Utility Services

VOC

WP

WS
Superfund Amendments and Reauthorization Act

state historic preservation officer

solid waste management unit

technetium

trichloroethane

trichloroethene

target compound list/target analyte list

total effective dose equivalent

thorium

thermoluminescent dosimeter

total organic carbon

Toxic Substances Control Act

total suspended solids

uranium

uranium hexafluoride

United States Enrichment Corporation

U.S. Environmental Protection Agency

underground storage tank

Lockheed Martin Utility Services

volatile organic compound

water pollution performance evaluation

water supply 


\section{Site and Operations Overview}

\section{Abstract}

The purpose of this document is to summarize the status of compliance with environmental laws, regulations, and orders; effluent monitoring data; and environmental surveillance results associated with U.S. Department of Energy (DOE) activities at DOE/PORTS. DOE requires that environmental monitoring be conducted and documented for all of its facilities under the purview of DOE Order 5400.1, General Environmental Protection Program and DOE Order 5400.5, Radiation Protection of the Public and the Environment. DOE activities at DOE/PORTS are waste management, environmental restoration, removal of highly enriched uranium (HEU), and operation of nonleased facilities. Production facilities for the separation of uranium isotopes are leased to the United States Enrichment Corporation (USEC). USEC activities are not covered by this document.

\section{BACKGROUND}

DOE/PORTS is owned by the U.S. Department of Energy (DOE). Effective July 1, 1993, DOE leased the production facilities at the site to the United States Enrichment Corporation (USEC), which was established by the National Energy Policy Act of 1992. Lockheed Martin Utility Services (Utility Services) manages and operates the leased facilities for USEC. Lockheed Martin Energy Systems (Energy Systems) remains the management and operating contractor for DOE responsibilities at the site, which are primarily waste management, environmental restoration, removal of highly enriched uranium (HEU), and operation of nonleased facilities.

This document contains a summary of DOE-related environmental monitoring activities at DOE/ PORTS. Environmental monitoring consists of two major activities: effluent monitoring and environmental surveillance. Effluent monitoring is direct measurement or the collection and analysis of samples of liquid and gaseous discharges to the environment. Environmental surveillance is direct measurement or the collection and analysis of samples of air, water, and soil. Environmental monitoring is performed to characterize and quantify contaminants, assess radiation exposures of members of the public, demonstrate compliance with applicable standards and permit requirements, and detect and assess the effects (if any) of DOE activities on the local environment. Multiple samples are collected throughout the year and are analyzed for radioactivity, chemical content, and various physical attributes.

\section{DESCRIPTION OF SITE LOCALE}

DOE/PORTS is located in sparsely populated, rural Pike County, Ohio, on a 5.8-square-mile site (see Figure 1.1). The site is two miles east of the Scioto River valley in a small valley running parallel to and approximately $120 \mathrm{ft}$ above the Scioto River floodplain. Figure 1.2 depicts the plant site and its immediate environs.

Pike County has approximately 24,250 residents. Scattered rural development is typical; however, the county contains numerous small villages, such as Piketon, Wakefield, and Jasper, that lie within a few miles 


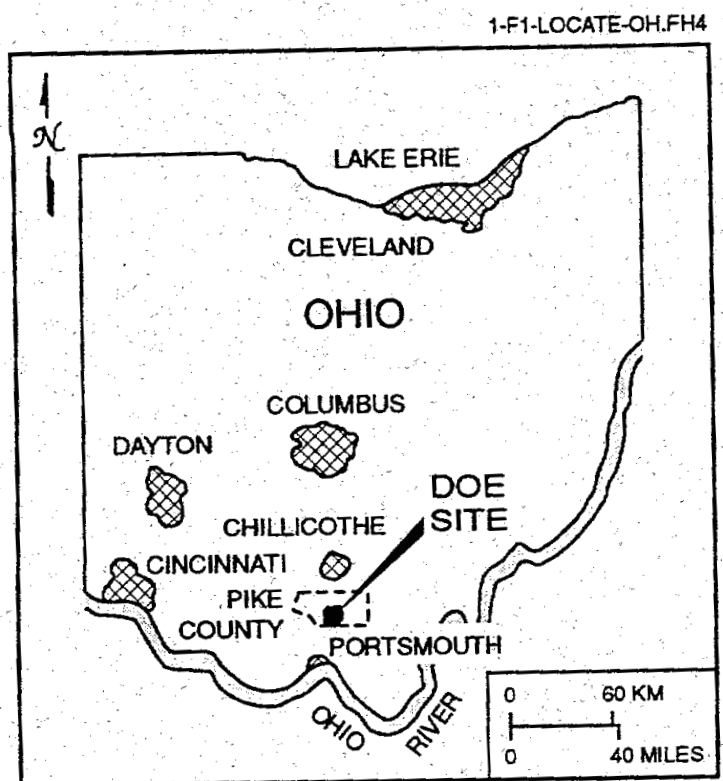

Fig. 1.1. Location of DOEPORTS within the state of Ohio.

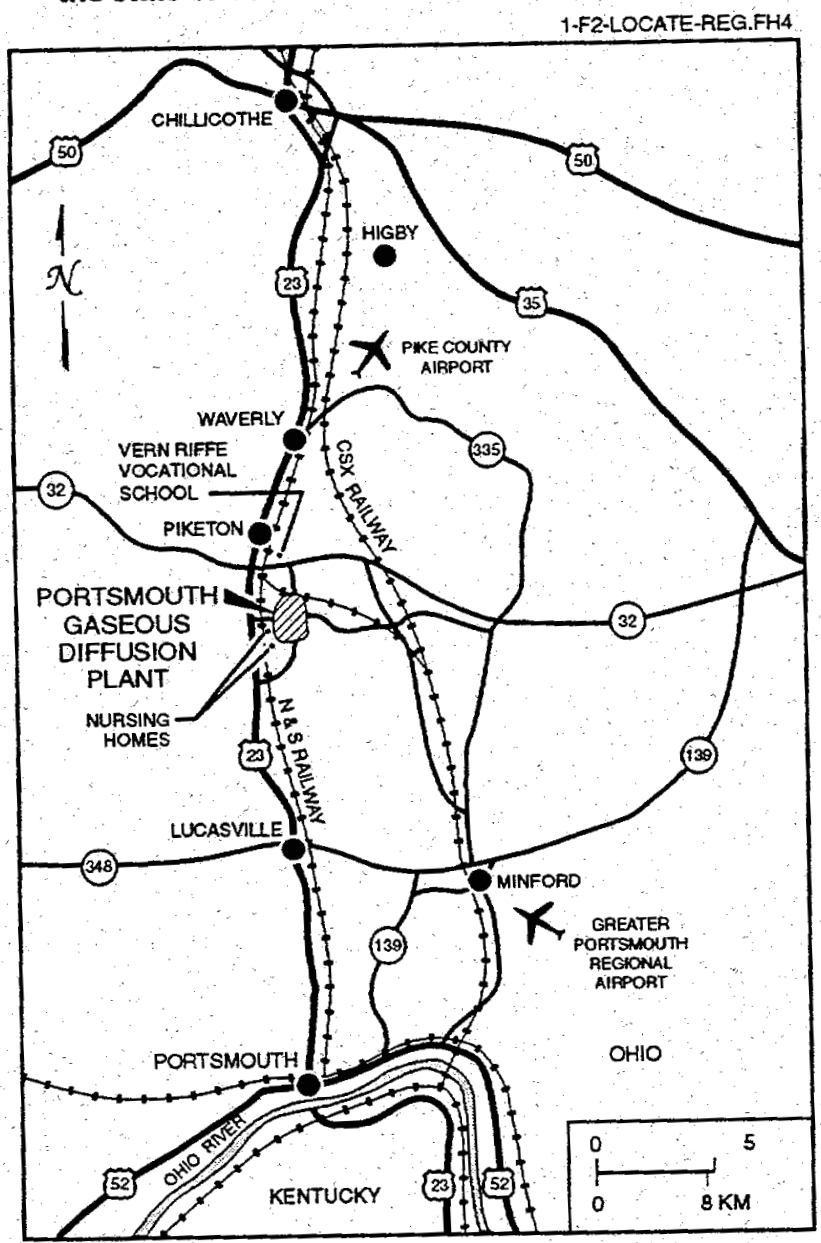

Fig. 1.2. Location of DOE/PORTS in relation to the geographic region. of the plant. The county's largest community, Waverly, is about 10 miles north of the plant site and has a population of about 4,500 residents. The nearest residential center in this area is Piketon, which is about five miles north of the plant on U.S. Route 23; its population is about 1,700 . Several residences are adjacent to the southern half of the eastern boundary and along Wakefield Mound Road (old U.S. 23), directly west of the plant. Two nursing homes, with a combined capacity of 60 persons, are located along Wakefield Mound Road.

Additional population centers within 50 miles of the plant are Portsmouth (population 22,249), 27 miles south; Chillicothe (population 21,923), 27 miles north; and Jackson (population $6,144), 18$ miles east. The total population of the area lying within a 50 -mile radius of the plant is approximately 900,000 (U.S. Department of Commerce 1991).

\section{DESCRIPTION OF SITE OPERATIONS}

DOE, through its managing contractor, Energy Systems, operates the waste management, environmental restoration, and highly enriched uranium removal programs at the plant, as well as other nonleased DOE property. The environmental restoration staff performs remedial investigations to define the nature and extent of contamination, evaluates the risks to public health and the environment, and determines the available alternatives from feasibility studies of potential remedial actions for sites under investigation. The goal of the environmental restoration program is to ensure that releases from past operations and waste management at DOE/ PORTS are thoroughly investigated and that appropriate remedial action is taken for the protection of human health and the environment.

\section{1-2 Site and Operations Overview}




\title{
2. Environmental Compliance
}

\begin{abstract}
Ongoing self-assessments are conducted at the Department of Energy (DOE) Portsmouth site to identify environmental issues. These issues are discussed frequently with regulatory agencies to ensure that appropriate actions are taken to achieve compliance.
\end{abstract}

\section{BACKGROUND AND OVERVIEW}

DOE/PORTS is required to operate in conformance with environmental requirements established by a number of federal and state statutes and regulations, executive orders, DOE orders, and compliance and settlement agreements. This section summarizes the plant's compliance status with regard to these various authorities.

Several federal, state, and local agencies are responsible for enforcing environmental regulations at DOE/PORTS. As of July 1, 1993, responsibility for implementing environmental compliance was divided between DOE, as site owner and operator of waste management and environmental restoration projects and other operations, and USEC, a government-owned corporation formed by the National Energy Policy Act of 1992 to assume the nation's uranium enrichment business. The management contractor for DOE is Energy Systems. A new subsidiary, Utility Services, was formed to provide management and operation services for USEC.

Under the terms of the lease between USEC and DOE, USEC assumed responsibility for compliance activities directly associated with uranium enrichment operations such as air emission permits for cascade vents and maintenance facilities, National Pollutant Discharge Elimination System (NPDES) compliance for the X-6619 sewage treatment plant and other leased facilities, and management of solid wastes generated by enrichment operations (with the exception of "legacy" wastes mentioned subsequently). DOE retains responsibility for the site Environmental Restoration Program; the Waste Management Program, including waste inventories that predate July 1, 1993, wastes generated by current DOE activities, and wastes containing legacy constituents, such as asbestos and polychlorinated biphenyls (PCBs); NPDES compliance at outfalls not leased to USEC; and air emission sources not leased to USEC. DOE also retains responsibility for HEU shutdown and operation of all nonleased facilities at DOE/PORTS. The Nuclear Regulatory Commission (NRC) is scheduled to assume direct oversight of USEC operations in 1997. In the interim, DOE is providing oversight until the NRC assumes regulatory authority.

Principal among other regulating agencies are the U.S. Environmental Protection Agency (USEPA) (both at Headquarters and Region V), the Ohio Environmental Protection Agency (Ohio EPA), the Ohio Department of Health $(\mathrm{ODH})$, and the Ohio State Fire Marshal's Office. These agencies issue permits, review compliance reports, participate in joint monitoring programs, inspect facilities and operations, and oversee compliance with applicable regulations.

Ongoing self-assessments of compliance status continue to identify environmental issues. These issues are discussed frequently with the regulatory agencies to ensure that appropriate actions are taken to achieve compliance. 



\section{COMPLIANCE ACTIVITIES}

\section{Resource Conservation and Recovery Act}

The Ohio Hazardous Waste Facility Board conducted a final hearing on July 21, 1995 approving the issuance of the Resource Conservation and Recovery Act (RCRA) Part B permit for storage of hazardous waste in the X-7725 and X-326 facilities. The Permit was issued to DOE/PORTS on August 21, 1995.

By December 31, 1995, certification of closure was received from the Ohio EPA for 10 RCRA facilities. Three additional units have been closed and are awaiting Ohio EPA certification. In July 1992, closure plans for the X-701C neutralization pit and the X-230J7 surface impoundment were submitted to the Ohio EPA. Per Ohio EPA request, closure plans for these two units were revised and resubmitted in late 1993. In 1995, DOE rescinded these two closure plans per Ohio EPA request. The Ohio EPA has designated each of these units as not requiring further action at this time. A closure plan was also submitted to the Ohio EPA for the X-344A neutralization pit in 1993 and amended in August 1995. The amendment documented risk-based closure levels for the X-344A Waste Neutralization Pit. Upon Ohio EPA approval of the risk-based closure plan, the closure certification was resubmitted in October 1995. Table 2.1 shows the current RCRA facility closure status.

Table 2.1. RCRA facility closure status at DOE/PORTS for 1995.

\begin{tabular}{|c|c|}
\hline Status & Facility \\
\hline Certification of closure received from the Ohio EPA & $\begin{array}{l}X-616 \text { surface impoundments } \\
X-705 \text { A incinerator } \\
X-749 \text { landfill (northern portion) } \\
X-749 \text { landfill (southern portion) } \\
X-750 \text { tank } \\
X-752 \text { container storage unit } \\
X-700 \text { tank } 6 \\
X-700 \text { tank } 7 \\
X-700 \text { tank } 8 \\
X-744 G(R) \text { container storage unit }\end{array}$ \\
\hline Closed and awaiting certification & $\begin{array}{l}X-744 G(U) \text { container storage unit } \\
\text { X-231B land treatment area } \\
\text { X-735 landfill (cells } 1-6)\end{array}$ \\
\hline Closure plans approved and closure under way & $\begin{array}{l}X-740 \text { tank } \\
X-740 \text { container storage unit } \\
X-744 Y \text { container storage yard }\end{array}$ \\
\hline Revised closure plans submitted to the Ohio EPA for review & $\begin{array}{l}X-701 B \text { holding pond } \\
X-701 C \text { neutralization pit } \\
X-230 J 7 \text { surface impoundment } \\
X-344 A \text { neutralization pit }\end{array}$ \\
\hline
\end{tabular}

\section{RCRA NOVs}

No Notices of Violation (NOVs) were issued to DOE/PORTS during 1995. There are currently five outstanding violations from previous audits. The five outstanding violations are:

- failure to make hazardous waste determinations regarding depleted $\mathrm{UF}_{6}$ cylinders and $\mathrm{LiOH}$,

- storage of hazardous waste in the X-700 tank number 7 for more than 90 days, 
- failure to conduct tank assessment of the X-700 tank numbers 6, 7, and 8 and the $X-740$ and X-750 tanks,

- lack of secondary containment for the five tanks listed above, and

- lack of a hazardous waste permit for X-700 tank number 7 .

Efforts are under way to negotiate a director's findings and orders with Ohio EPA for the depleted $\mathrm{UF}_{6}$ cylinders and LiOH, and to negotiate a judicial order with Ohio EPA for the remaining violations.

\section{Ohio Consent Decree and USEPA Administrative Consent Order}

A consent decree with the state of Ohio and an administrative consent order with the USEPA require the investigation and cleanup of releases to surface water and air; spills from past operations, including the elimination of groundwater contamination plumes; and solid waste management units (SWMUs), of which 77 have been identified. These 77 units are distributed over four areas (or quadrants) that are defined based on groundwater movement patterns. RCRA facility investigations (RFIs) for all quadrants have been completed, and reports have been submitted to the USEPA and the Ohio EPA.

The administrative consent order with the USEPA was revised on August 11, 1994, to incorporate those actions resolving NOVs issued by the USEPA in 1993 involving the Quadrant III RFI. The revision of the order also gave Ohio EPA day-to-day oversight of the cleanup work at DOE/PORTS. DOE agreed to pay a $\$ 50,000$ fine and conduct a supplemental environmental project costing a minimum of $\$ 1 \mathrm{M}$ or more. The proposed project will address the disposal of waste streams. Another requirement of the consent order, the regulatory milestone for submittal of the air RFI report to the USEPA and Ohio EPA on February 28, 1995, was met.

Director's Final Findings and Orders are being negotiated with the state of Ohio to address the management of depleted uranium hexafluoride $\left(\mathrm{UF}_{6}\right)$ and lithium hydroxide $(\mathrm{LiOH})$ stored at DOE/PORTS. In addition, a judicial order is being negotiated with the state of Ohio in order to resolve the outstanding noncompliances from previous RCRA inspections. These two agreements will settle the outstanding enforcement action by the state of Ohio. It is anticipated the two agreements will be finalized in 1996.

\section{Federal Facilities Compliance Act}

The Federal Facilities Compliance Act (FFC Act) was enacted by Congress in October 1992. Federal facilities are now required to develop and submit site treatment plans for treatment of mixed wastes. Approval authority for the site treatment plans has been transferred from the USEPA to the Ohio EPA. DOE/PORTS submitted a conceptual site treatment plan to the Ohio EPA in 1993 and a draft site treatment plan in 1994. The proposed site treatment plan was submitted in March 1995, and an amended proposed treatment plan in August 1995. A director's Final Findings and Orders was issued by Ohio EPA for the DOE/PORTS treatment plan on October 4, 1995.

\section{Comprehensive Environmental Response, Compensation, and Liability Act}

DOE/PORTS is not on the National Priorities List, and the USEPA and the Ohio EPA have chosen to oversee environmental remediation activities at DOE/PORTS under the provisions of RCRA. 
Reportable quantity (RQ) release reporting requirements for hazardous substances under the Comprehensive Environmental Response, Compensation, and Liability Act (CERCLA) Section 103 require notification to the National Response Center in the event of an RQ release. DOE/PORTS had no RQ releases of hazardous substances subject to CERCLA Section 103 notification requirements during 1995.

\section{Emergency Planning and Community Right-To-Know Act}

The Emergency Planning and Community Right-To-Know Act (EPCRA), also referred to as the Superfund Amendments and Reauthorization Act (SARA) Title III, requires reporting of emergency planning information, hazardous chemical inventories, and releases to the environment. EPCRA reports are submitted to federal, state, and local authorities.

EPCRA Section 304 requires reporting of off-site RQ releases to state and local authorities. EPCRA Sections 311 and 312 require provision of material safety data sheets (MSDSs) or a list of hazardous chemicals for which the MSDSs are required and annual submittal of hazardous chemical inventories, respectively, to state and local authorities. EPCRA Section 313 requires annual reporting of specified toxic chemical releases based on usage rate threshold quantities. The toxic chemical release inventory reports are sent annually to the USEPA and to the Ohio EPA.

DOE/PORTS had no RQ releases of hazardous chemicals subject to EPCRA Section 304 notification requirements during 1995. The Section 311 MSDS lists are frequently updated and provided to appropriate officials. The Section 312 inventory report for 1995 included the identity, location, storage information, and hazards associated with eight hazardous chemicals stored on unleased DOE properties. These eight hazardous chemicals were asphalt, calcium carbonate, diesel fuel, ethylene glycol, gasoline, lithium hydroxide, triuranium octaoxide, and uranium hexafluoride. Under EPCRA Section 313, four toxic chemicals, ethylene glycol, fluorine, hydrogen fluoride, and zinc, were released to the environment and were reported for 1995 from DOE held properties not leased to other establishments within the Portsmouth facility. The EPCRA Section 313 releases are summarized in Appendix $C$ of this report.

\section{Underground Storage Tanks}

The Underground Storage Tank (UST) Program is managed in accordance with the regulations of DOE, the USEPA, Ohio EPA, and the Ohio State Fire Marshal's Bureau of Underground Storage Tank Regulations (BUSTR). The BUSTR regulations are codified in the Ohio Administrative Code (OAC), Rule Chapter 1301:7-9. DOE/PORTS renewed the registration of 17 tanks with BUSTR in June 1995, including three that were listed as temporarily out of service and are empty or contain water. DOE leases 11 of the USTs at the site to USEC, and 1 to the Ohio Army National Guard. DOE has retained responsibility for environmental compliance for five of the USTs, three of which are temporarily out of service.

Tanks registered in 1994, but not included on the 1995 registration, include four tanks removed in 1994, one tank removed in 1995 (at the X-735A facility), and one tank which was discovered to be erroneously registered since 1988 . Additionally, two tanks (at the $X-7721$ facility) were deleted from the registry because it was determined that they never contained regulated substances, and are therefore not regulated by BUSTR.

The 4,000 gallon fiberglass tank located at the X-735A facility was removed in March 1995. A Closure Report documenting the removal operations was submitted to BUSTR in May 1995. In June 1995, DOE/PORTS received a letter from BUSTR indicating that "BUSTR requires no further action involving corrective actions for remediation under the regulatory framework" for the X-735A site.

\section{2-4 Environmental Compliance}


All DOE tanks are in compliance with current BUSTR regulations. Plans are being made to close DOE's three remaining out-of-service tanks. Additionally, according to current regulations, by December 22 , 1998, the remaining two USTs will be closed in order to meet current regulatory requirements.

\section{Toxic Substances Control Act}

The electrical power system at DOE/PORTS uses PCB transformers and large, high-voltage PCB capacitors to supply electricity to the enrichment cascade, as permitted under the Toxic Substances Control Act (TSCA). At the end of 1995, the site inventory of PCBs in electrical equipment (including spare equipment) was 168 PCB transformers and 11,110 large PCB capacitors.

PCBs that are not totally enclosed are in service at DOE/PORTS in duct gaskets. This use of PCBs is addressed in a federal facilities compliance agreement (FFCA) between DOE and the USEPA. The agreement required that troughs be installed under all motor exhaust duct gaskets to collect leaks of PCB oils. When leaks or spills of PCB material occur, they are managed in accordance with the FFCA.

DOE/PORTS operates several storage areas for PCB wastes. The storage areas meet all applicable requirements of 40 Code of Federal Regulations (CFR) 761.65 or the FFCA. All Portsmouth site solid PCB wastes are in long-term storage because of the lack of commercially available disposal facilities authorized to dispose of wastes containing both $\mathrm{PCBs}$ and radionuclides.

Other sections of TSCA have little or no impact on DOE/PORTS. Although friable asbestos is regulated under TSCA, the specific regulations applicable to the site are duplications of other state and federal regulations, specifically, the National Emission Standards for Hazardous Air Pollutants (NESHAP) and Occupational Safety and Health Administration regulations. DOE/PORTS also responds to USEPA requests for health and safety data as required, but because the site neither imports chemicals nor manufactures, processes, or distributes chemical substances for commercial purposes, such responses are generally simple negatives.

\section{Federal Facilities Compliance Agreement}

In February 1992, an FFCA between DOE and USEPA Headquarters that addresses PCB issues common to all three DOE uranium enrichment plants became effective. Several compliance issues were resolved. These issues included the use of PCBs in nontotally enclosed systems, storage of PCB-radioactive waste in accordance with nuclear criticality safety requirements, and storage of PCB-radioactive waste for longer than one year. As of the end of 1995, DOE/PORTS is in full compliance with the requirements and milestones of this FFCA.

A quarterly status report is compiled and submitted to DOE regarding progress toward the milestones specified in the FFCA. An annual compilation of the quarterly reports is submitted to the USEPA. In addition, DOE and USEPA representatives meet to resolve any unanticipated issues or uncertainties regarding the terms of the agreement. Two meetings were held in 1995, one in May and one in October, to discuss the FFCA status. The discussions in May addressed the schedule for gasket removal, annual progress at the sites, and a proposal associated with the characterization of process and support building wastes. At the October meeting, concurrence was granted by the USEPA formally documenting the proposal on the characterization of process and support building wastes. Additional comments and issues on the schedule for PCB gasket removal were also discussed during the October meeting. 


\section{Federal Insecticide, Fungicide, and Rodenticide Act}

No restricted-use pesticides are used by DOE/PORTS personnel. When application of a restricted-use pesticide is required, a certified contractor is used. Application of general-use pesticides by plant personnel is conducted according to product labeling; all product warnings and cautions are strictly obeyed. Application of pesticides by plant and contractor personnel must be approved by the plant pesticide coordinator.

\section{Clean Air Act and NESHAP}

\section{Ohio Permits To Operate}

Under $\mathrm{OAC} 3745-35$, any air contaminant source emitting more than $10 \mathrm{lb} / \mathrm{day}$ that is not permanently exempt requires the submission of a permit-to-operate application. As of the end of 1995, DOE PORTS had 14 state air permits to operate (PTOs), 17 registered sources ("registered" sources are listed by the Ohio EPA in lieu of receiving a formal permit), and 4 exempt sources. Of the 14 PTOs, nine are currently involved in an appeal with Ohio's Environmental Board of Review. No violations of air permit limits occurred during 1995.

\section{Clean Air Act, Title V, Permitting Program}

After an initial ruling that its submission was incomplete, the state of Ohio submitted a complete Title V program application to the USEPA on July 23,1994 . The USEPA approved Ohio's Title V Permitting Program on October 1, 1995. Ohio's Title V program is being implemented in essentially the same manner outlined in $40 \mathrm{CFR} 70$. Ohio will merge its major new source review program with the Title V program but will leave its minor new source review process separate. The USEPA's maximum achievable control technology rules will be adopted unchanged.

DOE operations at DOE/PORTS are not required to be permitted under the Title V program because DOE-related air emissions are below permitting thresholds for hazardous and criteria air pollutants. Radiological emissions subject to NESHAPS cannot by themselves cause a facility to become a Title V source.

\section{Clean Air Act, Title VI, Stratospheric Ozone Protection}

Several activities are proceeding to enable compliance with Title VI of the Clean Air Act amendments. As part of the Stratospheric Ozone Protection Plan, DOE has instituted a record-keeping system consisting of forms and labels to ensure compliance with the Title VI record-keeping and labeling requirements. These requirements affect all areas that use ozone-depleting substances in units or devices. The appliance service record and retrofit or retirement plan forms apply to those units with a capacity of more than $50 \mathrm{lb}$. The refrigeration equipment disposal log and associated appliance disposal label have been developed to be used by all units regardless of capacity. More than 140 air conditioning/refrigeration units and 30 motor vehicle air-conditioning units under DOE control have been identified. Maintenance and service of these units is conducted under contract. The contractor technicians who service the equipment have been properly trained in accordance with USEPA requirements. Additionally, DOE has verified that the technicians servicing the units have purchased approved recovery/recycling equipment and have submitted the equipment certifications to the USEPA.

\section{2-6 Environmental Compliance}




\section{NESHAP}

DOE gaseous radiological emissions were monitored at three active sources during 1995:

- X-326 top- and side-purge cascades,

- X-345 high-assay sampling area (HASA), and

- X-326 area 5 seal exhaust vent.

The radionuclides managed on site are the three natural uranium isotopes $\left({ }^{234} \mathrm{U}\right.$, ${ }^{235} \mathrm{U}$, and ${ }^{238} \mathrm{U}$ ) plus trace concentrations of the human-made radionuclides ${ }^{236} U$ and technetium- $99\left({ }^{99} \mathrm{Tc}\right)$ and the short-lived uranium daughters thorium-231 $\left({ }^{231} \mathrm{Th}\right)$, thorium-234 $\left({ }^{234} \mathrm{Th}\right)$, and protactinium-234 $\left({ }^{234 m} \mathrm{~Pa}\right)$. The uranium isotopes are all alpha radiation emitters, with the ${ }^{234} \mathrm{U}$ isotope accounting for the bulk of the alpha radiation released from the plant. The uranium daughters are all beta-gamma emitters. In general, the ${ }^{238} \mathrm{U}$ daughters ${ }^{(234} \mathrm{Th}$ and $\left.{ }^{234 m} \mathrm{~Pa}\right)$ dominate the ${ }^{235} \mathrm{U}$ daughter $\left({ }^{231} \mathrm{Th}\right)$. Technetium is a beta emitter that originally entered the process as a contaminant from reprocessed reactor fuel.

Gaseous radionuclide emissions are monitored and released continuously from the X-326 top- and side-purge cascades and the seal exhaust vents. Emissions from the X-345 HASA vent are intermittent.

DOE/PORTS is in compliance with the $10 \mathrm{mrem} /$ year radiological emission limit established by the USEPA; 1995 emissions from DOE activities were $0.005 \mathrm{mrem}$. The five most significant radionuclide emission sources are monitored by continuous vent samplers for radionuclides and fluorides. Stack tests for radionuclide emissions have been conducted on six minor sources. Emissions from other minor sources are estimated based on process knowledge and the emission factors in Appendix D of 40 CFR 61, "NESHAP."

On August 17-18, 1995, the USEPA conducted an inspection of DOE/PORTS for compliance with 40 CFR 61, Subpart H, "National Emission Standards for Emission of Radionuclides Other than Radon from Department of Energy Facilities." No actions were required as no violations were noted.

\section{Clean Water Act}

DOE was issued a new NPDES permit covering DOE activities and outfalls, effective September 1, 1995. This permit encompasses nine monitored outfalls, six of which are classified as point-source discharges to waters of the state. The remaining three outfalls are classified as internal outfalls, effluents from which go through another monitored outfall before reaching waters of the state.

Compliance rates (by individual parameter) at DOE outfalls ranged from $92 \%$ to $100 \%$. The overall DOE compliance rate for 1995 was $97 \%$. (The compliance rate is calculated by dividing the number of measurements that did not exceed the applicable permit limits by the total number of measurements made.) There were a total of 11 exceedences at DOE outfalls during 1995. The exceedences consisted of four total suspended solids, four oil and grease mass loading and three trichloroethene (TCE). High rainfall runoff routinely results in total-suspended-solids exceedences.

\section{National Environmental Policy Act}

The National Environmental Policy Act (NEPA) requires evaluation of the environmental impacts of activities at federal facilities and of activities funded with federal dollars. NEPA reviews are required for all projects to determine the potential for environmental impacts related to the following: 
- property (e.g., sites, buildings, structures, and objects) of historical, archaeological, or architectural significance, as officially designated by federal, state, or local governments, including those eligible for listing on the National Register of Historic Places;

- the potential habitat (including critical habitat) of federally listed endangered, threatened, proposed, or candidate species or of state-listed endangered and threatened species;

- federally listed endangered, threatened, proposed, or candidate species or state-listed endangered and threatened species;

- floodplains and wetlands;

- natural areas such as federally and state-designated wilderness areas, national parks, national natural landmarks, wild and scenic rivers, coastal zones, state and federal wildlife refuges, and marine sanctuaries;

- prime agricultural lands; and

- special sources of water (such as class I groundwater, sole-source aquifers, wellhead protection areas, and other water sources that are vital to a region).

Impacts to air, surface water, groundwater, biota, socioeconomics, environmental justice, and worker safety and health are also reviewed.

DOE/PORTS has a formal program dedicated to compliance with NEPA pursuant to DOE Order 451:1, National Environmental Policy Act Compliance Program. Restoration actions, waste management, enrichment facilities maintenance, and other activities are evaluated to determine the appropriate level of NEPA documentation. NEPA documents are produced by NEPA compliance program personnel and are submitted to DOE for evaluation and approval. (Note: environmental impact statements must be produced by an independent organization.) Routine operations and maintenance activities are evaluated to assess potential environmental impacts. Most activities performed on site qualify for categorical exclusion as defined in 10 CFR 1021, "NEPA Implementing Procedures," and as listed in Subpart D, Appendices (a) and (b). These activities are considered to have no significant individual or cumulative environmental impacts. In 1995, eight generic categorical exclusions were in effect for DOE/PORTS actions. An environmental assessment titled "Construction and Operations of an Industrial Solid Waste Landfill at Portsmouth Gaseous Diffusion Plant, Piketon, Ohio" was approved by DOE-Oak Ridge Operations in 1995. A revised environmental assessment titled "Modifications and Expansion of X-7725A Waste Accountability Facility for Storage of Polychlorinated Biphenyl Wastes of Portsmouth Gaseous Diffusion Plant, Piketon, Ohio" was submitted to DOE-Oak Ridge Operations for review and comment in 1995. Three individual categorical exclusions were approved for DOE/PORTS actions in 1995.

The quadrant-wide Cleanup Alternatives Study/Corrective Measures Study (CMS) reports were reviewed for compliance with NEPA in 1995. Each SWMU grouping and corrective measures alternatives were reviewed with preliminary NEPA determinations made and matrixed for each quadrant. This matrix will enable DOE/PORTS to quickly determine the level of NEPA documentation required for any alternative prior to preferred alternative selection by the regulators. Quarterly audits of Maintenance Service Requests (MSRs) were initiated in 1995 to determine and sustain compliance of maintenance actions with NEPA. No deficiencies were noted in 1995. 


\section{Other Environmental Acts and Federal Regulations}

\section{Endangered Species Act}

The Endangered Species Act of 1973, as amended, provides for the designation and protection of rare and threatened wildlife and plants. The Act also serves to protect ecosystems on which such species depend. Field surveys are performed, and mitigating measures are designed as needed. When appropriate, formal consultations with the U.S. Fish and Wildlife Service and the Ohio Department of Natural Resources are made. A threatened and endangered species habitat survey was completed in October 1994. A bat survey was completed in September 1994. No field surveys were completed in 1995.

\section{National Historic Preservation Act}

The National Historic Preservation Act of 1966 is the primary law governing the protection of cultural resources (archaeological and historical properties). Cultural resource reviews are conducted on a case-by-case basis, and consultations with the Ohio state historic preservation officer (SHPO) are made as required by Section 106 of the Act. Two cultural resource reviews were conducted in 1995 . One of the cultural resource reviews resulted in approval of a "Memorandum of Agreement" among the DOE, the Ohio SHPO and The Advisory Council on Historic Preservation. A draft programmatic agreement (PA) among the DOE, the Ohio SHPO, and The Advisory Council on Historic Preservation, concerning the management of historical and cultural properties at DOE/PORTS was submitted to the SHPO for review and comment in 1995.

\section{Archaeological and Historic Preservation Act, and Archaeological Resources Protection Act}

The Secretary of the Department of the Interior (DOI) is required to report to Congress on various federal archaeological activities by the Archaeological and Historic Preservation Act (AHPA) and by the Archaeological Resources Protection Act (ARPA), as amended. ARPA requires federal land managers to provide archaeology program information to the Secretary of the Interior for this report. The Department of the Interior Questionnaire on Fiscal Year 1994 Federal Archaeological Activities at the Portsmouth Gaseous Diffusion Plant was completed and submitted to DOE Headquarters for forwarding to the DOI in 1995 to satisfy this requirement.

\section{Farmland Protection Policy Act}

The Farmland Protection Policy Act of 1981 requires federal agencies to consider the effects of their proposed actions on prime farmiand. Prime farmland is generally defined as land that has the best combination of physical and chemical characteristics for producing crops of statewide or local importance. When required, prime farmland surveys are conducted, and consultations with the U.S. Department of Agriculture's Natural Resources Conservation Service are made. No prime farmland surveys were conducted at DOE/PORTS in 1995. 


\section{Title 10 CFR 1022, “Compliance with Floodplain/Wetlands Environmental Review Requirements"}

Title 10 CFR 1022 establishes policy and procedures for compliance with Executive Order 11988, "Floodplain Management," and Executive Order 11990, "Protection of Wetlands." Activities (other than routine maintenance) proposed within 100-year and 500-year floodplains or in wetlands first require that a notice of involvement be published in the Federal Register. A floodplain or wetland assessment is required by DOE. These assessments must discuss the effects of the proposed project on the floodplain or wetland and any alternatives or mitigating measures that would lessen adverse impacts. For floodplains, a floodplain statement of findings summarizing the floodplain assessment is also required by DOE and must be published in the Federal Register for public comment at least 15 days prior to beginning the project. A preliminary wetland survey of DOE/PORTS was completed in 1995. The preliminary wetland survey identified a number of areas considered wetlands or emergent wetlands.

\section{Ecological Risk Assessment}

In the summer and fall of 1993, DOE began preparing a baseline ecological risk assessment for DOE/ PORTS. Included as part of the risk assessment were a wetland survey, a threatened and endangered species habitat survey, a bat survey, fish community surveys, benthic macroinvertebrate community studies, a water toxicity testing task, sediment toxicity testing, soil toxicity testing, and fish tissue analyses. A préliminary wetland survey, which identified a number of areas considered wetlands or emergent wetlands, was completed in 1995.

\section{Ohio Agreement in Principle}

On October 26, 1993, an Agreement in Principle (AIP) became effective between DOE and the state of Ohio regarding joint oversight of the three DOE facilities in Ohio (Fernald Environmental Management Project, the Mound Plant, and DOE/PORTS). The AIP provides approximately $\$ 11 \mathrm{M}$ over a five-year period to the state to be used to review the environmental compliance and monitoring programs and data, supplement existing state and local emergency management programs, and promote better state and public understanding of DOE environmental activities at the three sites. The grant authorization was approved in early 1994 . The Ohio EPA is the lead state agency for the AIP, which includes the Ohio Department of Health and the Ohio Emergency Management Agency (Ohio EMA).

As part of the AIP program, the Ohio EPA participated in the taking of split samples on five occasions during 1995. Split water samples were taken of NPDES outfall waters and from naturally occurring water bodies near DOE/PORTS. Split sediment samples were taken of sediments found in the nearby streams and river formations. Also as part of the program, Ohio EMA participated in training and emergency management exercises for DOE/PORTS.

The AIP participants meet on a regular basis to discuss progress and the AIP in general. One such meeting was held at DOE/PORTS on November 30,1995 . The Ohio plan for oversight at DOE/PORTS is under revision. 


\section{DOE Order Compliance}

\section{DOE Order 5400.1, General Environmental Protection Program}

DOE Order 5400.1 provides direction for compliance with the USEPA and state and local environmental regulations, and establishes requirements for internal environmental protection programs. DOE/PORTS maintains compliance with federal, state, and local statutes through implementation of requirements found in the Clean Air Act, Clean Water Act, RCRA, TSCA, the Safe Drinking Water Act, and other appropriate statutes.

DOE/PORTS environmental protection programs mandate the creation of several environmental reports. These reports include the radioactive effluent and on-site discharge data report submitted annually to the Waste Information Systems Branch at Idaho National Engineering Laboratory; the five-year plan required by the Office of Management and Budget Circular A-106; the annual site environmental report; and reports of significant nonroutine releases of hazardous substances, consistent with DOE Order 232.1, Occurrence Reporting and Processing of Operations Information. An environmental protection implementation plan (EPIP) is required to be prepared and updated annually. The EPIP defines specific environmental objectives, including the means and schedules for accomplishing those objectives. An environmental monitoring plan (EMP) is to be prepared, reviewed annually; and updated every three years. The EMP defines a comprehensive system to provide effluent monitoring and environmental surveillance of effluents from DOE/ PORTS. The monitoring program includes all environmental media-surface water, groundwater, air, earth, and biological media. The EMP is designed to meet federal and state regulatory requirements as well as those internal to DOE/PORTS. In response to an August 1995 DOE audit of the environmental monitoring program, individual EMPs are being developed for DOE operations.

Quality assurance and data evaluation are primary considerations for DOE/PORTS monitoring, surveillance, sampling, and analytical activities. Independent data verification is conducted. This aspect of monitoring is targeted for increased attention in the future. Audits of monitoring and sampling activities by state and federal regulatory agencies have been positive, and no significant findings have been issued.

\section{Pollution Prevention and Waste Minimization}

Pollution prevention activities are administered at DOE/PORTS through the Pollution Prevention Awareness Program. The purpose of this program is to foster the philosophy that source reduction is preferred over reclamation, reuse, or recycling. Reclamation, reuse, or recycling is preferred over treatment, and treatment is preferred over disposal, the last resort in the pollution prevention hierarchy, as referenced in the Pollution Prevention Act of 1990. DOE participates in the voluntary "Ohio Prevention First" program, an initiative sponsored by the state of Ohio that promotes pollution prevention programs. The goal of the program is to incorporate pollution prevention into the decision-making process at every level throughout the organization. The program, required by DOE Order 5400.1, has been incorporated into the site Waste Minimization Program because both programs have compatible goals and program elements.

The Pollution Prevention Awareness Program consists of (1) pollution prevention awareness through newsletters, bulletins, and memoranda; (2) awards, recognition, and performance indicators; (3) information exchange; and (4) training. Other recognized pollution prevention measures are the Best Management Practices Plan and the Portsmouth Spill Prevention, Control, and Countermeasures Plan.

Waste minimization efforts include segregation of radioactive and nonradioactive wastes and reduction of radiological control areas, with an associated reduction in use of disposable and washable personal protective equipment. Mixed waste (hazardous waste mixed with radionuclides) minimization efforts 
include segregating hazardous wastes from radioactive contaminated wastes, reduction of absorbent cloth use in PCB spill cleanup, and material substitution. Procedures have been implemented requiring a waste management plan and project checklists that address pollution prevention and waste minimization practices. Nonhazardous waste minimization efforts include a sanitary waste recycling program that includes recycling aluminum cans, corrugated cardboard, office waste paper, and spent fluorescent light bulbs. Additionally, a computer software program has been purchased for tracking hazardous materials within DOE holdings at DOE/PORTS. This system will be instrumental in eliminating the most hazardous chemical products stored in inventory.

Proposed waste minimization projects include recycling lead acid batteries and scrap metal. The development of a site waste minimization team, continuation of waste minimization training for employees, and performing pollution prevention opportunity assessments on selected waste streams and activities are expected to identify additional waste minimization opportunities.

\section{Environmental Training}

Environmental training is a continuous process at DOE/PORTS. During 1995, training included environmental compliance, hazardous waste operations, and RCRA-generator training. Hazardous waste operations training is conducted at three levels, including a 24 -hour course, a 40 -hour course, and an 8-hour refresher course. This training satisfies occupational safety and health requirements specified in 29 CFR 1910.120, "Hazardous Waste Operations and Emergency Response." RCRA training courses are specific, dealing with hazardous waste generators and treatment, storage, and disposal operations. This training satisfies RCRA requirements specified in 40 CFR 265.16, "Personnel Training," and OAC-3745-54-16(D), "Personnel Training."

\section{Groundwater Protection Program}

\section{Scope of the Groundwater Protection Program}

DOE Order 5400.1 outlines requirements for groundwater monitoring at all DOE facilities and specifies the development of three individual documents relating to groundwater monitoring: an EMP (discussed previously), a groundwater protection program management plan (GWPPMP), and a groundwater monitoring plan. The GWPPMP formalizes and structures the DOE/PORTS groundwater protection program (GWPP) by identifying and assigning specific roles and responsibilities to the various staff within the plant who are matrixed to the program. The DOE/PORTS plan meets the requirements for a GWPPMP as described in DOE Order 5400.1. The contents of this plan have been updated and assembled to reflect the following scope:

- Define the purpose, policies, objectives, and history of the GWPPMP.

- Define regulations, requirements, and guidance applicable to groundwater monitoring at DOE Portsmouth.

- Provide a brief description of the hydrogeologic conditions and known groundwater contamination at DOE/PORTS.

- Describe the groundwater monitoring strategies used at DOE/PORTS to meet the applicable regulations and requirements.

- Define the organizational roles and responsibilities of the GWPP, including interfaces with other programs. 
- Define the documentation required for GWPP projects.

- Provide the most effective overall management possible for the GWPP.

The DOE/PORTS GWPPMP is a dynamic document that will be updated and revised routinely. The format allows updating of individual sections independent of the rest of the document. The plan as a whole will be reviewed annually and will be revised and reissued every three years. Sections that are revised between reissue dates will be numbered and dated. Where appropriate, the GWPPMP incorporates material by reference; all referenced materials are subject to annual review, revision, and reissue.

\section{Purpose, Policies, and Objectives of the DOE/PORTS GWPP}

The purpose of the DOE/PORTS GWPP is to characterize the hydrogeology and monitor the groundwater quality at DOE/PORTS and its environs. Related tasks are conducted primarily in support of (1) environmental surveillance activities, (2) land disposal units requiring groundwater monitoring under RCRA, (3) the Remedial Action Program, (4) UST monitoring, and (5) land disposal units requiring groundwater monitoring under state solid waste regulations (OAC-3745-27 and 3745-29). Support for this program is provided in many forms, including technical advice and assistance, well installation and development, sampling and analysis, data management, data interpretation, report preparation, regulatory negotiation, and implementation of monitoring and corrective actions.

\section{Groundwater Investigations at DOE/PORTS}

In 1994, DOE/PORTS revised and issued the four quadrant RFI reports, completed field activities and issued a draft report for an off-site soil and groundwater background study, and initiated the CMS process. Seven draft CMS reports (Quadrant I, Quadrant II, X-701B, Peter Kiewit landfill, X-749/X-120, X-611A, and $\mathrm{X}-705 \mathrm{~A}$ and $\mathrm{B}$ ) were submitted to the Ohio EPA and USEPA. After addressing regulatory comments, two draft CMS reports $(X-611 \mathrm{~A}$ and $\mathrm{X}-705 \mathrm{~A}$ and $\mathrm{B})$ were issued as final drafts.

In addition, construction activities for the $\mathrm{X}-749$ and Peter Kiewit landfill interim remedial measures were completed. At the southern boundary of the DOE/PORTS reservation, the installation of a subsurface barrier (in the unconsolidated soil and into the top $4 \mathrm{ft}$ of bedrock) was completed. This barrier will preclude continued southward migration of contaminated groundwater from the X-749 landfill. At the Peter Kiewit landfill, a groundwater interceptor trench was installed and Big Run Creek was relocated to prevent volatile organic contaminants (primarily vinyl chloride) from entering Big Run Creek.

A geologic and hydrogeologic reconnaissance was completed for property adjoining the DOE/PORTS southern boundary. A cone penetrometer was used to collect geologic data (four borings) and seven groundwater samples. In addition, six small-diameter piezometers (less than 2 in.) were installed on the property. Analytical results for the groundwater samples did not show volatile organic contamination on the property.

\section{DOE Order 5400.5, Radiation Protection of the Public and the Environment}

DOE Order 5400,5 provides guidance and establishes radiation protection standards and control practices designed to protect the public and the environment against undue radiological risk from operations of DOE and DOE contractors. The order requires that off-site radiation doses not exceed $100 \mathrm{mrem} / \mathrm{year}$ above background. In 1995, the total off-site dose from DOE/PORTS was $0.13 \mathrm{mrem} /$ year, including airborne emissions, consumption of locally produced foodstuffs (including fish caught in the Scioto River), and consumption of drinking water from the Scioto River. 
DOE/PORTS is also well below all applicable media-specific dose limits, such as the USEPA limit of $10 \mathrm{mrem} / \mathrm{year}$ from airborne emissions and the DOE derived concentration guides (DCGs) for specific nuclides in wastewater and storm water discharges (6.7\% of the USEPA limit and $0.67 \%$ of the DOE limit). DOE/PORTS conducts various modeling and dose assessment activities from samples and other information collected to address the potential for multiple-pathway exposures of the public. DOE/PORTS is in compliance with the requirements of this order.

\section{DOE Order 5820.2A, Radioactive Waste Management}

DOE Order 58.20.2A establishes policies, guidelines, and minimum requirements for managing radioactive waste and contaminated facilities.

All radioactive wastes generated at DOE/PORTS are classified as low-level waste (LLW) or mixed waste and are subject to DOE Order 5820.2A, Chapter III, "Management of Low-Level Waste." This order requires that all radioactive wastes be treated, stored, or disposed of at DOE facilities. Facilities have been identified for this purpose (e.g., DOE's Hanford facility in Richland, Washington), and procedures and protocols are being established to provide proper access to these facilities. DOE/PORTS has initiated shipments to Hanford. One waste stream has currently been approved under Handford's waste specification system. Additional approvals will be sought on a waste stream basis as required.

Commercial facilities are also available for treatment, storage, and disposal, and DOE has provided a method of approving use of these facilities for small quantities of waste. DOE/PORTS is proceeding to ship wastes under the recently negotiated nationwide contract between DOE and Envirocare of Utah, Inc., for disposal of mixed waste.

LCW is segregated into four primary waste types according to applicable treatment technology and/or regulatory requirements. These waste types are (1) burnables, (2) scrap metal, (3) other nonburnables, and (4) mixed (RCRA-LLW and PCB-LLW). Storage requirements for each of these waste types diminish the potential for environmental release. DOE/PORTS is in compliance with the requirements of this order.

\section{Occurrences Reported to Regulatory Agencies}

Because the potential exists to generate RQ releases from Portsmouth site operations, DOE/PORTS is required to evaluate spills and unanticipated releases to determine if such incidents are reportable as prescribed in 40 CFR 117.2, "Notice of discharge of a reportable quantity," 40 CFR 302.6, "Notification requirements," 40 CFR 355.40 , "Emergency release notification," 40 CFR 761.125, "Requirements for PCB spill cleanups," or Ohio NPDES permit conditions.

In 1995, DOE/PORTS reported nine occurrences to regulatory agencies. Of these occurrences, seven were NPDES occurrences involving 11 permit exceedences reported to the Ohio EPA for the months of March, April, May, September and October of 1995. On March 14, 1995, a PCB decontamination rinse water release of unknown quantity was discharged from a shower stall to the sewer and reported to the USEPA Office of Pesticide and Toxic Substance Branch and the National Response Center. On December 12, 1995 a chlorine trifluoride gas cylinder release was reported to the Pike County Sheriff's Office, the National Response Center, and the Ohio EPA. Subsequent investigation concluded that the actual release quantity (less than one pound) did not meet or exceed the reportable quantity threshold. 


\section{Compliance Audits of Environmental Programs}

During 1995, 12 audits, appraisals, or inspections of the DOE/PORTS programs were conducted. The audits, appraisals, or inspections are listed in Table 2.2 and are summarized as follows:

On April 11, 1995, the Federal Energy Regulatory Commission (FERC) conducted the annual dam stability inspection of the X-611A, X-611B, and X-230K "high risk" impoundments and the X-230K sludge drying bed. No unexpected findings were noted. While "high risk" impoundments require an annual inspection, all others require an inspection only once every five years. Since all impoundments at DOE/ PORTS were last inspected in 1991, next year all are due to be inspected again. On May 31, 1995, photographs and information pertaining to the inspection were provided to FERC.

On May 11, 1995, the Ohio EPA and the Pike County Health Department conducted a landfill compliance inspection of X-749A, X-749 (southern portion), and the X-735 industrial solid waste landfills. The inspection team was also provided a tour of the $\mathrm{X}-230 \mathrm{~K}$ project to become more familiar with the sludge issue. The inspection team was pleased with the condition of the areas inspected, and there were no findings.

Table 2.2. Environmental audits and inspections at DOEPORTS for 1995.

\begin{tabular}{lll}
\hline Date & \multicolumn{1}{c}{ Auditor } & \multicolumn{1}{c}{ Type } \\
\hline April 11 & $\begin{array}{l}\text { DOE/Federal Energy Regulatory } \\
\text { Commission }\end{array}$ & Annual dam and dike inspection \\
May 11 & Pike County Health Dept/Ohio EPA & Landfill compliance inspection \\
June 7 & Ohio EPA & Annual RCRA audit \\
June 21 & Ohio EPA & Annual NESHAP compliance inspection \\
July 31-August 9 & DOE (Oak Ridge Operations) & ES\&H and QA assessment \\
August 7-16 & internal & Integrated technical audit \\
August 17-18 & USEPA & NESHAP compliance inspection \\
September 7 & Pike County Health Dept & Quarterly landfill inspection \\
September 15 & Ohio EPA & Annual air emission source inspection \\
November 14 & BUSTR & UST inspection \\
November 16 & Ohio EPA & Closure certification inspection \\
December 29 & Pike County Health Dept & Quarterly landfill inspection \\
\hline
\end{tabular}

On June 7, 1995, the Ohio EPA conducted their unannounced annual RCRA compliance audit. DOE/ PORTS received no NOVs or negative observations as a result of this inspection.

The annual NPDES inspection was conducted by the Ohio EPA on June 21, 1995. No noncompliances were noted. Ohio EPA noted that DOE/PORTS was substantially in compliance with the terms and conditions of the permit at the time of the inspection.

A functional assessment of selected environmental, safety, health, and quality assurance areas at DOE was conducted by DOE Oak Ridge Operations technical representatives from July 31 through August 9, 1995. The assessment was part of the DOE/PORTS management assessment program and serves as an assessment of the management and operating contractor in this function area. The audit report included six issues.

The 1995 integrated technical audit of DOE/PORTS was conducted from August 7 through 16, 1995, by the Energy Systems Central Compliance Evaluation, and Policy staff. The audit report included nine findings, 21 observations, and three proficiencies.

On August 17-18, 1995, a representative from the USEPA, Region V, conducted a NESHAP compliance inspection of DOE/PORTS. The inspection was to confirm compliance and the closing of all 
concerns noted during the March 1993 USEPA compliance inspection. There were no findings, and USEPA made a number of very favorable comments including noting that DOE/PORTS is the first facility nationwide to demonstrate compliance without entering into a federal facilities compliance agreement.

On September 7, 1995, the quarterly landfill inspection was conducted by the Pike County Health Department No deficiencies were noted. A representative from the Ohio EPA also visited the site to obtain information about the landfill to aid his management team in deciding on the response to a call-in Permit to Install (PTI) exemption request submitted from DOE/PORTS to the Ohio EPA in April 1995.

On September 15, 1995, the Ohio EPA's Division of Air Pollution Control conducted the annual DOEJPORTS air compliance inspection. Areas inspected included the X-735 RCRA closure vent system, the $X-735$ industrial landfill refuse and asbestos handling, roadways and parking areas, and the inoperative $X-700$ contaminated water treatment systems. No discrepancies were noted.

On November 14, 1995, representatives from BUSTR visited DOEPORTS to review the current registration of underground storage tanks for accuracy and for a short tour of the site. The BUSTR representatives indicated that they would recommend that the Fire Marshal grant the request for a variance to extend the time period to remove the out-of-service tanks at X-751 from 12 months to approximately three years. On November 27, 1995, DOE/PORTS was notified by the Fire Marshal that the request for the variance was approved.

On November 16, 1995, the Ohio EPA visited DOE/PORTS to provide concurrence on the completion of the $\mathrm{X}-744 \mathrm{G}(\mathrm{U}), \mathrm{X}-744 \mathrm{~A}$, and the $\mathrm{X}-740$ closures. Ohio EPA indicated that closure certification approval for these projects, where applicable, would be forthcoming. Closure certification approval for X-700 tank number 7 has been forwarded from Ohio EPA Southeast District to Ohio EPA Headquarters in Columbus for final approval.

On December 29,1995 the Pike County Health Department conducted a quarterly inspection of the $\mathrm{X}-735$ Industrial Solid Waste Landfill. There were no deficiencies identified during the inspection.

\section{ENVIRONMENTAL PERMITS}

Table 2.3 lists the current environmental permit status for DOE/PORTS.

Table 2.3. DOERORTS environmental permits for 1995.

\begin{tabular}{lcc}
\hline Permits & No permits & No permits \\
& applied for & received \\
\hline Air (Clean Air Act) & 14 & $12(17)^{2}$ \\
NPDES (Clean Water Act) & 1 & 1 \\
NPDES Construction storm water & 4 & 4 \\
discharge permits & & \\
RCRA & 1 & 1 \\
X-735 sanitary landfill license & 1 & 1 \\
\hline
\end{tabular}

a Air sources registered by the Ohio EPA in lieu of formal permits to opera

\section{Clean Air Act Permit Status}

At the end of 1995, DOE had 14 permits to operate (PTOs), 17 registered sources, and 4 exempt sources. Nine PTOs are under the appeal process with the Ohio Environmental Board of Review.

\section{2-16 Environmental Compliance}





\section{Clean Water Act Permit Status}

A new NPDES permit was issued to DOE and became effective September 1, 1995. The permit addresses only DOE activities.

\section{RCRA Permit Status}

In March 1993, the Ohio EPA submitted the RCRA Part B permit application to the Ohio Hazardous Waste Facility Board On July 21, 1995, the Ohio Hazardous Waste Facility Board approved the DOE/ PORTS RCRA Part B permit. The permit was issued on August 21, 1995.

\section{Land Disposal Restriction Waste}

DOE/PORTS is currently storing RCRA hazardous waste and low-level radioactive RCRA mixed waste. The RCRA hazardous waste is subject to RCRA land ban provisions, which permit storage only to attain sufficient quantities to facilitate proper treatment, recycling, or disposal. Low-level radioactive RCRA waste (mixed waste) is also regulated under land disposal restriction (LDR); however, the FFC Act provides limited relief from LDR regulation. An October 4, 1995, Director's Final Findings and Orders (DF\&O) was issued by the Ohio EPA to implement the FFC Act; allowing storage of mixed waste beyond one year. The DF\&O provides for implementation of the PORTS approved Site Treatment Plan.

\section{X-735 Industrial Solid Waste Landfill Permit Status}

The X-735 Industrial Solid Waste (ISW) landfill is the only permitted solid waste facility at DOE $I$ PORTS and is in compliance with its permit for disposal of solid waste. A license to operate the landfill is obtained annually from Pike County, Ohio. Wastes accepted at the X-735 landfill include cafeteria wastes, industrial wastes, disinfected medical wastes (except drugs), construction and demolition debris, and asbestos (in designated locations). No hazardous wastes, TSCA wastes, or radioactive wastes are permitted in this facility. Asbestos disposal is conducted in accordance with NESHAP and OAC 3745-20, "Asbestos Handling-Demolition, Renovation, Disposal."

DOE/PORTS construction spoils area (X-736), located immediately west of the X-735 ISW landfill, is an operating landfill for materials not regulated as solid wastes by the state of Ohio. Materials of this type include certain construction and demolition debris that do not contain hazardous or toxic substances. 



\title{
3. Environmental Program Information
}

\begin{abstract}
The goal of the environmental programs at DOE/PORTS is to assess the effects of DOE operations at the site on the environment and public health and to maintain the quality of the surrounding environment. DOE/PORTS has an extensive environmental monitoring program that consists of radiological and nonradiological monitoring of liquid and gaseous discharges, ambient air, and groundwater. Monitoring is based on environmental regulations, critical pathways analyses, public concerns, and measurement capabilities. Other environmental programs at DOE/PORTS include waste management, environmental restoration, waste minimization and pollution prevention, training, information exchanges, and public and employee awareness.
\end{abstract}

\section{ENVIRONMENTAL MONITORING PROGRAM}

Because environmental restoration is a significant part of DOE/PORTS's primary mission, the environmental monitoring effort is directed toward collecting and analyzing samples for compliance with regulatory requirements. Radioactive materials are regulated at the point of discharge and are monitored as they disperse into the surrounding environment. However, most radionuclides are released in such small amounts that it is not possible to detect them after they disperse into a medium, such as water, soil, or vegetation. For this reason; mathematical models are uséd to estimate the transport and dispersion of radionuclides into the environment. Basically, this involves monitoring the source of the contamination (i.e., the discharge stack or pipe) where higher concentrations than those found in a sampling medium may be readily obtained. Modeling can then be used to calculate the expected concentrations of contaminants in environmental media.

These models are also used to help optimize the effectiveness of the existing radiological monitoring program. For example, predictions based on models can be very beneficial in choosing the best locations for measuring devices and in identifying important pathways and contaminants. Modeling contributes to the best use of resources available for sampling and analysis and helps to verify that a sampling network is performing adequately.

Extensive monitoring is also conducted for nonradioactive contaminants. The nonradiological monitoring program is designed to ensure that the physical and chemical properties of atmospheric and liquid discharges comply with state and federal standards. Monitoring of atmospheric releases is designed to ensure compliance with permits issued by the Ohio EPA. Monitoring requirements for liquid effluents vary at each outfall, or discharge point, depending on the type of facility and the known characteristics of the wastewater.

\section{Goals}

The environmental monitoring program is designed for the assessment of DOE/PORTS operations on the environment and public health. This is accomplished through the collection and analysis of samples. The results are compared with defined standards. These results are used to gauge the environmental impact of DOE/PORTS operations and to set priorities for further environmental improvements. 


\section{Rationale}

The justification for choosing certain environmental media to be sampled, specific sampling locations, sampling frequencies, and parameters is referred to as the rationale. Environmental regulations, critical pathways analyses, public concerns, and measurement capabilities must all be considered in the rationale for the establishment of a successful environmental monitoring program. The rationale for the establishment of DOE/PORTS environmental monitoring program is found in the Environmental Monitoring Plan for the Portsmouth Gaseous Diffusion Plant (MMES 1994), which was distributed in November 1996. It was revised to address only DOE/PORTS activities.

\section{Environmental Regulations}

Numerous state and federal regulations that encompass radiological and nonradiological programs are drivers for much of the monitoring conducted at DOE/PORTS. These regulations include NESHAP, NPDES, RCRA, and NEPA. Compliance with these regulations involves a number of regulators, including the USEPA and the Ohio EPA, which oversee various site activities to help ensure compliance. In addition to these regulations are DOE orders in the 5400 series, in particular 5400.1, General Environmental Protection Program, and 5400.5, Radiation Protection of the Public and the Environment. A complete discussion of the site's compliance activities is in Section 2 of this report, "Environmental Compliance."

Acceptable levels of contaminants are generally specified in regulations or permits relating to nonradioactive substances. Regulations relating to radioactive materials generally include limits for exposure to the public. As discussed in Section 5, "Dose," DOE/PORTS uses USEPA-approved mathematical models to estimate the dispersion of radioactive contaminants in the environment and resulting exposures to the off-site population.

\section{Critical Pathways Analyses}

Individuals can be exposed to airborne and liquid releases of radioactive and chemical materials through various routes. These routes are referred to as pathways. Environmental reports were examined to determine which radionuclides and exposure pathways are most important in terms of the quantity of radionuclides released, the dose received by the maximally exposed individual, and the collective dose received by the population as a whole. This type of analysis, called a critical pathways analysis, is a good indicator for determining which radionuclides and pathways at a particular site deserve the most attention. Critical pathways analyses have been used historically at DOE/PORTS as input for the environmental monitoring program.

The following sections summarize the results of a critical pathways analysis of DOE/PORTS operations. The analysis includes radionuclide releases to the atmosphere and surface water, which are the principal media that could transport radioactive contaminants from the site.

\section{Air}

Air provides a potential exposure pathway to humans for radionuclides released into the atmosphere. Therefore, air sampling is conducted to evaluate the potential dose to local populations. Monitoring measures include radiological and nonradiological air emissions from individual buildings and specific facility locations. This information is used to help protect the health and safety of DOE/PORTS workers and the general public and to demonstrate compliance with state and federal air quality regulations.

\section{3-2 Environmental Program Information}




\section{Surface Water}

Surface waters at DOE/PORTS are analyzed to ensure compliance with water quality standards, establish background water quality, evaluate the potential for contaminant releases, and to comply with monitoring regulations and permits.

\section{Summary of Radionuclides}

The three natural uranium isotopes $\left({ }^{234} \mathrm{U},{ }^{235} \mathrm{U}\right.$, and ${ }^{238} \mathrm{U}$ ), and technetium ( ${ }^{99} \mathrm{Tc}$ ), are potentially significant when calculating the radiation dose received by the public around DOE/PORTS. Each of these radionuclides has a half-life that exceeds 200,000 years; consequently, the sampling frequency does not need to allow for radioactive decay. The types of radiation emitted vary from one radionuclide to the next. The predominance of beta and alpha emitters indicates the importance of internal exposures resulting from possible ingestion or inhalation of radionuclides.

\section{Important Pathways for Radionuclides from DOE/PORTS}

Exposure to radioactive materials could occur from releases to the atmosphere, surface water, or groundwater. In addition, a dose could be received through direct external inradiation by radiation emanating from buildings and other objects (e.g., depleted uranium drum and burial areas) located within plant and reservation boundaries. Doses are estimated for all potentially significant exposure pathways relevant to the exposure modes just described.

\section{Implications of Pathway Analysis for Environmental Monitoring}

Models used to assess any environmental impact relating to the transport of radionuclides and chemicals, and human exposures to these substances released from DOE/PORTS are appropriate for the situation encountered. Those pathways of exposure to the most-exposed individual and to the entire population residing within 50 miles of DOE/PORTS are evaluated.

Each assessment is documented. A file is created that contains the results of each calculation, a description of models used, a description of any computer codes used to implement the models, and a complete list of the values and sources of all input data and assumptions used. Surface water and groundwater modeling are conducted as necessary to conform with applicable requirements of the state government and of the regional USEPA office.

\section{Public Concerns}

Although the actual amount of a radiological material or a chemical substance released is of great concern to the public, its effect on the environment and public health is of even greater concern. Such concern can arise when a release could be transported to neighborhoods or schools. Concern can also exist for releases of long-lived radionuclides that remain in the environment for many years.

\section{Measurement Capabilities}

Many of the radioactive and nonradioactive materials released from DOE activities exist in such low concentrations in the environment that they cannot be measured readily. Thus, measurement capabilities 
become determining factors in the rationale for monitoring certain materials. In these cases, modeling, as previously discussed, can be used to estimate concentration levels.

\section{Environmental Monitoring Program Changes in 1995}

Environmental monitoring practices are re-evaluated as new methods and the need for monitoring evolve. Types of measurements and their frequencies are reviewed routinely, and monitoring locations are sometimes changed. The primary change in the environmental monitoring program in 1995 was that DOE was issued an NPDES permit governing only DOE outfalls.

Following issuance of the DOE NPDES permit, a new Environmental Monitoring Plan for DOE Activities has been formulated. The plan, required by DOE Order 5400.1, was distributed in November 1996. The plan documents DOE effluent monitoring and environmental surveillance activities conducted at DOE/ PORTS. The plan also includes the rationale and design criteria for the environmental monitoring program, the frequency of monitoring and analysis, specific analytical and sampling procedures, quality assurance requirements, and guidance on preparing and distributing reports.

\section{ENVIRONMENTAL QUALITY}

Maintaining the quality of the environment at DOE/PORTS and in the surrounding communities. requires programs that involve several site departments and organizations. These programs are extensive and varied, involving not only site personnel but also members of the general public. Activities include waste management, environmental restoration (ER), waste minimization and pollution prevention, environmental training, and information exchange and public awareness programs.

\section{Waste Management Program}

The DOE/PORTS Waste Management Program directs the safe storage, treatment, and disposal of waste generated by past and present operations and from current ER projects. The primary objective is to ensure that waste materials do not migrate into the environment. Waste managed under the program is divided into six categories: low-level radioactive, hazardous, mixed, PCB and PCB-radioactive, asbestos, and conventional sanitary waste:

- Low-level radioactive waste-radioactive waste not classified as high level or transuranic and that does not contain any components regulated by RCRA or TSCA.

- Hazardous waste - waste that contains one or more of the wastes listed under RCRA or that exhibits one or more of the four RCRA hazardous characteristics: ignitability, corrosivity, reactivity, and toxicity.

- Mixed waste - waste containing both hazardous and radioactive components. Mixed waste is subject to RCRA, which governs the hazardous components, and to additional regulations that govern the radioactive components.

- $P C B$ and PCB-radioactive wastes - waste containing PCBs, a class of synthetic organic chemicals including 209 known isomers, each with from one to 10 chlorine atoms on a biphenyl ring. Under TSCA regulations, PCB manufacturing was prohibited after 1978. However, continued use of PCBs is allowed, provided that the use does not pose a risk to human health or the environment. Disposal of all PCB materials is regulated. 
- Asbestos waste-friable asbestos materials from renovation and demolition activities.

- Sanitary waste - waste that is neither radioactive nor hazardous. Solid sanitary waste is basically refuse and is disposed in landfills. Liquid sanitary waste includes sewage and industrial waste treated at the DOE/PORTS sewage treatment plant.

Waste management requirements are varied and are sometimes complex because of the variety of waste streams generated by DOE/PORTS activities. DOE Orders, Ohio EPA, USEPA, and Ohio Department of Health regulations must be satisfied to ensure compliance for waste management activities. Supplemental policies have been implemented for management of radioactive, hazardous, and mixed wastes. These policies include

- minimizing wastes;

- characterizing and certifying wastes before they are stored, processed, treated, or disposed; and

- pursuing volume reduction and use of on-site storage when safe and cost-effective until a final disposal option is identified.

\section{Environmental Restoration Program}

DOE established the.ER Program to find, analyze, and correct site contamination problems as quickly and cost-effectively as possible. The ER Program encompasses both inactive sites (remedial action) and active facilities (decontamination and decommissioning). Options for correcting or mitigating the contaminated sites and facilities include removal, containment, and treatment of contaminants.

The DOE/PORTS ER Program is designed to ensure that activities meet federal and state requirements (primarily RCRA) and DOE Orders. The Ohio EPA and USEPA oversee the DOE/PORTS ER Program through their respective agreements with DOE. The Ohio Consent Decree became effective August 29, 1989. The Administrative Consent Order, between the USEPA and DOE, became effective in 1989 and was revised on August 11,1994. These agreements establish a program of corrective actions to be taken and a schedule for their completion.

As required in these agreements, DOE/PORTS ER Program activities are conducted in accordance with the RCRA corrective action process, which consists of the following:

- Description of current conditions - to provide knowledge of the current environmental setting of the groundwater, surface water, soil, and air.

- RCRA facility assessment - to identify releases of contaminants and determine the need for further investigation.

- RCRA facility investigation - to determine the nature and extent of any contamination.

- Corrective measures study - to evaluate and select a remediation alternative.

- Corrective measures implementation - to implement the selected remediation measure.

- Interim remedial measures - to implement quick remediation or mitigation measures in advance of permanent action.

Because of the size of the facility and the nature of groundwater flow, DOE/PORTS was divided into four quadrants for investigation and cleanup.

The DOE/PORTS ER Program was developed in 1989 and was granted an initial budget of $\$ 13.8 \mathrm{M}$. Since then, annual program expenditures have grown to as much as $\$ 50 \mathrm{M}-\$ 60 \mathrm{M}$. RFIs have been completed for all quadrants, and CMSs have been submitted to the agencies. As a result of potential threats to human health and the environment, five interim remedial measures (IRMs) were implemented. 


\section{Waste Minimization and Pollution Prevention Program}

DOEJPORTS has combined its waste minimization and pollution prevention efforts to consolidate related activities. Objectives of the DOE/PORTS Waste Minimization and Pollution Prevention Program include

- fostering a philosophy to conserve resources and create a minimum of waste and pollution;

- promoting the use of nonhazardous materials in plant operations to minimize potential risks to human health and the environment;

- reducing or eliminating the generation of wastes through material substitution, product reformulation, process modification, improved housekeeping, and on-site closed-loop recycling; and

- complying with federal and state regulations and DOE policies and requirements for waste minimization.

The DOE/PORTS Waste Minimization and Pollution Prevention Program continues activities to achieve the waste minimization objectives. Typical projects include

- maintaining a comprehensive waste tracking and reporting system;

- evaluating all plant processes and activities to identify waste minimization opportunities (e.g., conducting process waste assessments and identifying procedures that are barriers to waste minimization);

- maintaining an effective plant-wide waste minimization training program;

- maintaining a waste minimization and pollution prevention awareness promotional campaign; and

- providing a waste minimization and pollution prevention information exchange network.

\section{Environmental Training Program}

DOE/PORTS provides environmental training to increase employee awareness of environmental activities and to enhance the knowledge and qualifications of personnel performing tasks associated with environmental assessment, planning, and restoration. The program includes on- and off-site classroom instruction, on-the-job training, seminars, and specialized workshops and courses. Environmental training conducted or prepared by DOE/PORTS includes

- hazardous waste site training for workers;

- hazardous waste site training for managers/supervisors;

- RCRA training for treatment-, storage-, and disposal-facility workers;

- environmental laws and regulations training; and

- water/wastewater treatment training.

\section{Information Exchange Program}

To improve and update its environmental monitoring and research programs, DOE/PORTS exchanges information within the site and with other DOE facilities and other sources of information. 


\section{Technical Information Exchange}

DOE/PORTS representatives attend both DOE-sponsored and independent technical information exchange workshops such as the annual DOE Model Conference, quarterly multi-plant task team meetings, and professional conferences.

\section{Public Awareness Program}

A comprehensive community relations and public participation program on the ER and Waste Management programs has been established since early 1990. The purpose of the program is to conduct a proactive public involvement program, with outreach components, to foster a spirit of openness and credibility among local citizens, elected officials, business, media, and various segments of the public. The program is also geared to provide the public with opportunities to become involved in the decisions affecting environmental issues at the plant.

DOE/PORTS opened a public Environmental Information Center in February 1993 in an effort to provide public access to all documents used to make decisions on remedial actions being taken at the plant. The information center has a full-time staff and is located about 10 miles north of the plant at 505 West Emmitt Avenue, Suite 3, Waverly, Ohio 45690 . The center's hours are 10 a.m. to 4 p.m., Monday, Tuesday, Wednesday, and Friday, and 9 a.m. to 12 p.m. on Thursday, or after hours by appointment (614-947-5093).

A group of about 45 key stakeholders, composed of elected officials, community leaders, environmentalists, and other individuals who have expressed an interest in the ER and Waste Management programs, is targeted for information and input on current activities and those actions under consideration at the plant. Semiannual public update meetings and public workshops on specific topics are also held to keep the public informed and to receive their comments and questions. Periodically, fact sheets about major projects are written for the public. Semiannual newsletters are printed and distributed to more than 4,000 recipients, including the community relations mailing list, neighbors within two miles of the plant, and all plant employees and retirees.

Points of contact have been established for the public to obtain information or direct questions regarding the ER and Waste Management programs. The DOE Deputy Site Manager is the primary point of contact (614-897-5510). The Energy Systems site manager and the public affairs manager also provide information on the program.

\section{Ohio Agreement in Principle}

The Ohio AIP is a program originated by DOE in which DOE contributes funding to state agencies for resident state personnel to oversee environmental compliance of DOE activities at the three DOE facilities within the state of Ohio (the Fernald Environmental Management Project near Cincinnati; the Mound Plant, Miamisburg; and DOE/PORTS, Piketon). The lead state agency for AIP is the Ohio EPA. Ohio EMA and ODH also participate in the AIP program. 



\title{
4. Effluent Monitoring
}

\begin{abstract}
Environmental monitoring at DOE/PORTS is conducted to assess the impact of plant operations on the surrounding environment. The DOE/PORTS environmental monitoring program includes direct monitoring of air, surface water, and groundwater. Samples are analyzed for radiological contaminants as well as potentially harmful nonradiological pollutants. Monitoring is confined to National Pollutant Discharge Elimination System (NPDES), groundwater and air sampling conducted within the plant boundaries. The release of airborne pollutants from DOE/PORTS is regulated by permits from the state of Ohio and the U.S. Environmental Protection Agency. The majority of liquid effluents from DOE/PORTS are regulated by the NPDES. A total of $0.002 \mathrm{Ci}$ of radioactivity was released to surface water from DOE/PORTS outfalls in 1995. These levels represent a decrease in uranium and technetium emissions from 1994. For nonradiological releases, overall compliance with the NPDES permit limits was $97 \%$. Results for 1995 indicate that DOE/PORTS operations did not have a significant environmental impact outside the reservation boundaries.
\end{abstract}

\section{INTRODUCTION}

DOE/PORTS practices a progressive environmental strategy for pollution control in compliance with requirements of the Clean Air Act and the Clean Water Act. This strategy uses modern pollution abatement technology followed by continual review of treatment facility performance to meet current regulations regarding airborne and liquid effluents in the most cost-effective manner. DOE/PORTS has maintained an environmental monitoring network since 1964. DOE/PORTS activities have historically contributed minimal pollutants to the environment.

\section{AIRBORNE DISCHARGES}

This section briefly describes major radiological and nonradiological air emission sources and associated emission control and emission monitoring systems at DOE/PORTS, followed by a summary of the total annual emission data and a discussion of its significance.

\section{Radiological Airborne Discharges}

As a result of the formation of USEC, DOE leased the enrichment operations facilities at DOE PORTS to USEC. Under the terms of the lease, USEC assumed responsibility for most of the existing radionuclide point-source discharges. The primary source of radiological discharges to the air at DOE/PORTS is the uranium enrichment cascade itself, which could release radionuclides through USEC sources one and two (the top-side E-jet and Seal Exhaust 6) and DOE sources one and two (seal exhaust 5 and X-345). The X-345 HASA, formerly a cascade support facility, is now operated by DOE/PORTS as a continuously monitored source. This source is currently out of service but could become operational again if necessary. 


\section{Regulatory Requirements}

Airborne discharges of radionuclides from DOE/PORTS facilities are regulated by the USEPA under the Clean Air Act and NESHAP. These regulations set (1) an annual dose limit of $10 \mathrm{mrem} / \mathrm{year}$ to any member of the public as a result of airborne releases from DOE facilities and (2) certain minimum performance standards for demonstrating compliance with the dose limit.

Gaseous radionuclide discharges are also regulated, along with all other atmospheric pollutants, under the Ohio permit-to-operate regulations. However, Ohio does not yet have any standards governing radionuclide emission limits and defers to the federal NESHAP program instead of acting on permit applications filed by DOE/PORTS.

In addition to these outside authorities, DOE regulates radionuclide emissions to all environmental media through DOE Orders 5400.1, General Environmental Protection Program, and 5400.5, Radiation Protection of the Public and the Environment (to be replaced by 10 CFR Part 834). DOE Order 5400.5 sets an annual dose limit of $100 \mathrm{mrem} /$ year to any member of the public. Unlike the NESHAP limit, the DOE limit includes the impacts of radioactivity releases from a facility through all pathways.

DOE Order 440.1, Worker Protection Management for DOE Federal and Contractor Employees, DOE Order 441.1, Department of Energy Radiological Health and Safety Policy, and 10 CFR Part 835, Occupational Radiation Protection, require DOE facilities to establish effluent monitoring programs sufficient to ensure that no unrecognized environmental impact is occurring as a result of DOE operations. The details of the DOE/PORTS environmental monitoring program will be documented in the Environmental Monitoring Plan for the Portsmouth Gaseous Diffusion Plant, which is discussed in detail in Section 2, "Environmental Compliance."

\section{Radiological Airborne Sample Collection and Analytical Procedure}

Gaseous radionuclide and fluoride emissions from the purge cascade vents, the X-345 HASA vent, seal exhaust 5, seal exhaust 6 and the top-side E-jet vents are sampled continuously. Only a percentage of the seal exhaust 6 and top-side E-jet emissions are from DOE. The continuous vent samplers draw a flowproportional sample of the vent stream through two small alumina traps in series by way of an isokinetic probe. The primary sample traps are replaced weekly, and the secondary traps are replaced quarterly.

A waste stream analysis was performed to determine what radionuclides are present on site. These radionuclides are the naturally occurring uranium isotopes ${ }^{234} \mathrm{U},{ }^{235} \mathrm{U}$, and ${ }^{238} \mathrm{U}$; two trace impurities from recycled uranium, ${ }^{236} \mathrm{U}$ and ${ }^{99} \mathrm{Tc}$; and equilibrium concentrations of short-lived uranium daughters. Alumina from the sampler is analyzed for total uranium, ${ }^{235} \mathrm{U}$, and technetium. The ratio of ${ }^{235} \mathrm{U}$ to total uranium (i.e., the "assay") and the process data are used to calculate the fractions of ${ }^{234} U$ and ${ }^{236} U$ in emissions. Because of their short half-lives, uranium daughter emissions cannot be reliably measured in weekly samples and are assumed to be in equilibrium with their parent nuclides. The uranium daughters included in the equilibrium calculations are the thorium and protactinium isotopes ${ }^{234} \mathrm{Th}$, ${ }^{231} \mathrm{Th}$, and ${ }^{234 m} \mathrm{~Pa}$.

\section{Radiological Airborne Results}

Radionuclide emissions from DOE/PORTS (Table 4.1) had no significant impact on public health or the environment. Total radionuclide emissions from the site increased in 1995 because of the addition of emission estimates from unmonitored sources. In 1995, DOE/PORTS included emission estimates using the factors for emissions from unmonitored sources in the calculation of the effective dose equivalent (EDE), found in Appendix D of this document. The conservative estimates accounted for the majority of the increase in the dose. There were no unplanned releases during 1995. DOE/PORTS emissions still remain well below 
the applicable USEPA standard and far below the levels listed as safe by national and international regulatory bodies such as the Occupational Safety and Health Administration, the NRC, and the International Committee on Radiation Protection.

Table 4.1. Radionuclide releases to air from DOE activities at the Portsmouth site in $1995^{\circ}$.

\begin{tabular}{|c|c|}
\hline Radionuclide & $\mathrm{Ci} /$ year $^{\mathrm{b}}$ \\
\hline${ }^{234} \mathrm{U}$ & 0.00895 \\
\hline${ }^{235} \mathrm{U}$ & 0.000734 \\
\hline${ }^{236} \mathrm{U}$ & $8.93 \mathrm{E}-7^{\mathrm{c}}$ \\
\hline${ }^{238} \mathrm{U}$ & 0.000192 \\
\hline Total uranium & 0.0097 \\
\hline${ }^{99} \mathrm{Tc}$ & 0.0147 \\
\hline Uranium daughters & 0.00059 \\
\hline
\end{tabular}

aexcludes USEC activity releases

$1 \mathrm{Ci}=3.7 \mathrm{E} 10 \mathrm{~Bq}$

${ }^{c}=0.000000893$

Historically, uranium has accounted for $75 \%$ to almost $90 \%$ of the public dose from DOE/PORTS emissions. Consequently, the emission control systems on the cascade are optimized to reduce uranium emissions first and technetium emissions second. Figures 4.1 through 4.3 show DOE/PORTS emission levels for uranium and technetium over the last five years. Figures 4.1 and 4.2 show uranium emissions in curies (a measure of radioactivity) and kilograms (a measure of mass), respectively. Emissions of uranium isotopes from DOE sources during 1995 were $0.0097 \mathrm{Ci}$, which is equivalent to $0.686 \mathrm{~kg}(1.6 \mathrm{lb})$. Both figures are included because uranium is a mixture of three different isotopes $\left({ }^{236} \mathrm{U}\right.$ is a trace contaminant) with widely varying specific activities, producing varying levels of curies per kilogram. Because of this, $1 \mathrm{Ci}$ of uranium can weigh from 20 to $6,600 \mathrm{lb}$, depending on the proportions of isotopes present. For the future, it is expected that mass emissions (kilograms) of uranium will remain about the same as levels seen from 1989 through 1995, and that the activity emissions (curies) of uranium should continue to decrease after 1993 because of the absence of highly enriched uranium in the emissions.

Emissions of uranium daughters have ranged from 0.002 to $0.028 \mathrm{Ci} /$ year since 1986 and have never had a significant impact on the environment or public health. Emissions from DOE/PORTS sources during 1995 were $0.0006 \mathrm{Ci}$.

Figure 4.3 shows technetium emissions in curies. Because only one isotope of technetium is present at DOE PORTS, a figure showing mass emissions would provide no information not found in Figure 4.3. Mass emissions of technetium from DOE/PORTS sources in 1995 were $0.864 \mathrm{~g}$ $(0.002 \mathrm{lb})$, which is equivalent to $0.0240 \mathrm{Ci}$.

\section{Nonradiological Airborne Discharges}

DOE/PORTS operations also release various nonradiological substances to the atmosphere. Fluorides are

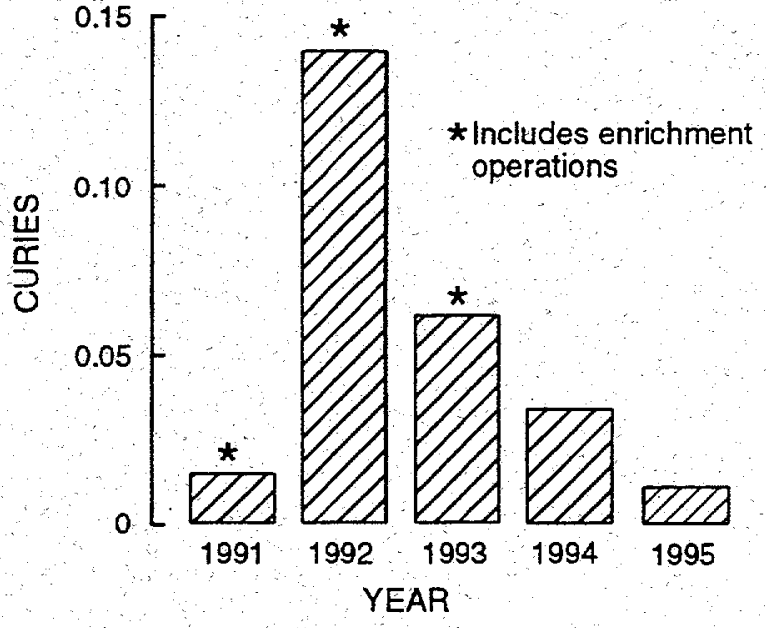

Fig. 4.1. Total curies of uranium discharged to air from DOE sources, $1991-1995\left(1 \mathrm{Ci}=3.7 \times 10^{10} \mathrm{~Bq}\right)$. 


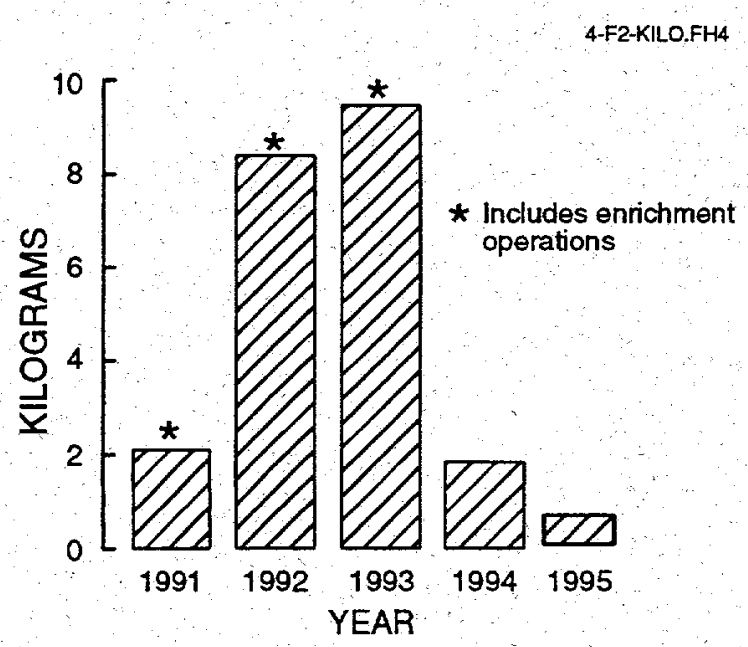

Fig 4.2. Total kilograms of uranium discharged to air from DOE sources, 1991-1995.

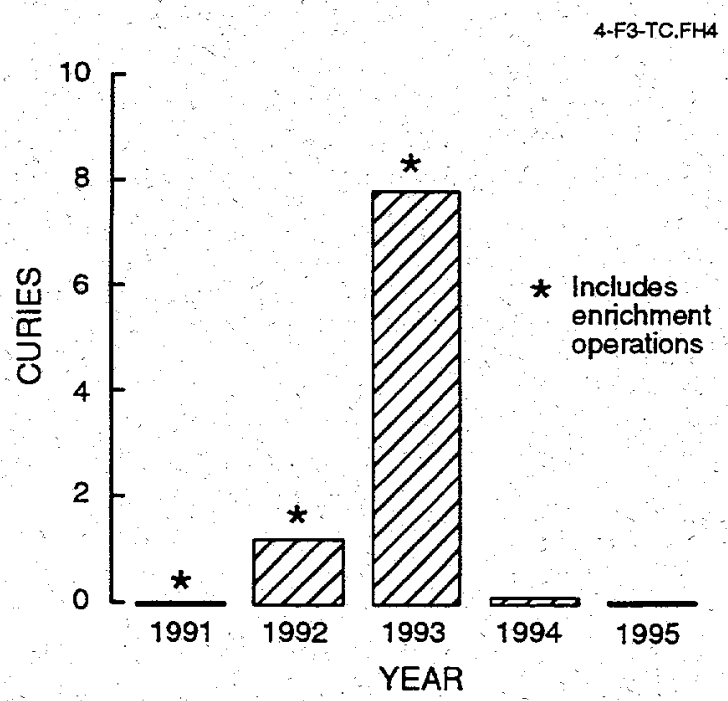

Fig. 4.3. Total curies of technetium discharged to air from DOE sources, 1991-1995 (1 Ci = 3.7 × 10 10 Bq). present in the cascade vents as various reactive fluoride gases, including $\mathrm{UF}_{6}$ and hydrogen fluoride (HF). These emissions are monitored directly with the continuous vent samplers. In addition, several types of airborne emissions are calculated from process data or from purchasing records. All of these emissions are now the responsibility of USEC.

\section{Regulatory Requirements}

Discharges to the atmosphere are regulated under the Ohio permit-to-operate regulations. Under Ohio regulations, the Ohio EPA can "register" small emission sources rather than issue a formal permit. Permits to operate must be renewed every three years and set out explicit numerical limits on emission rates or operating restrictions and on monitoring and reporting requirements. A registration is valid until revoked by the Ohio EPA and presumes that the registered source is too small to have a significant environmental impact. Most of the nonradiological sources at DOE/PORTS are either registered or are expected to be registered when the Ohio EPA acts on the submitted applications.

\section{Background}

DOE/PORTS operates numerous small sources of criteria (or conventional) air pollutants. Air pollutants emitted from DOE/PORTS include chlorine, hydrogen fluoride (HF), methanol, assorted solvents, and coolants. The amounts of these chemicals emitted are estimated for annual reports to the USEPA as required under Section 313 of SARA and are incorporated in this report.

Another air pollutant present at DOE/PORTS is asbestos released by renovation or demolition of plant facilities. Asbestos emissions are not included under Section 313 of SARA, and no quantified emission level is available. Asbestos emissions are controlled by a system of work practices supervised by the Industrial Hygiene Department. The amount of asbestos removed and disposed of is reported quarterly to the Ohio EPA.

\section{LIQUID DISCHARGES}

This section briefly describes major water discharge sources and associated control and monitoring systems at DOE/PORTS that are DOE responsibilities. A summary of total annual radiological and nonradiological discharges and a discussion of the significance of the data and of any anomalies follow.

Existing DOE/PORTS collection and treatment facilities are discussed in this section together with facility improvements, new treatment facilities, and studies to improve performance. Varieties of hazardous liquid wastes - uranium contaminated as well as noncontaminated - result from operations associated with remediation activities. Major DOE wastewater sources and systems are shown in Figure 4.4.

\section{4-4 Effluent Monitoring}




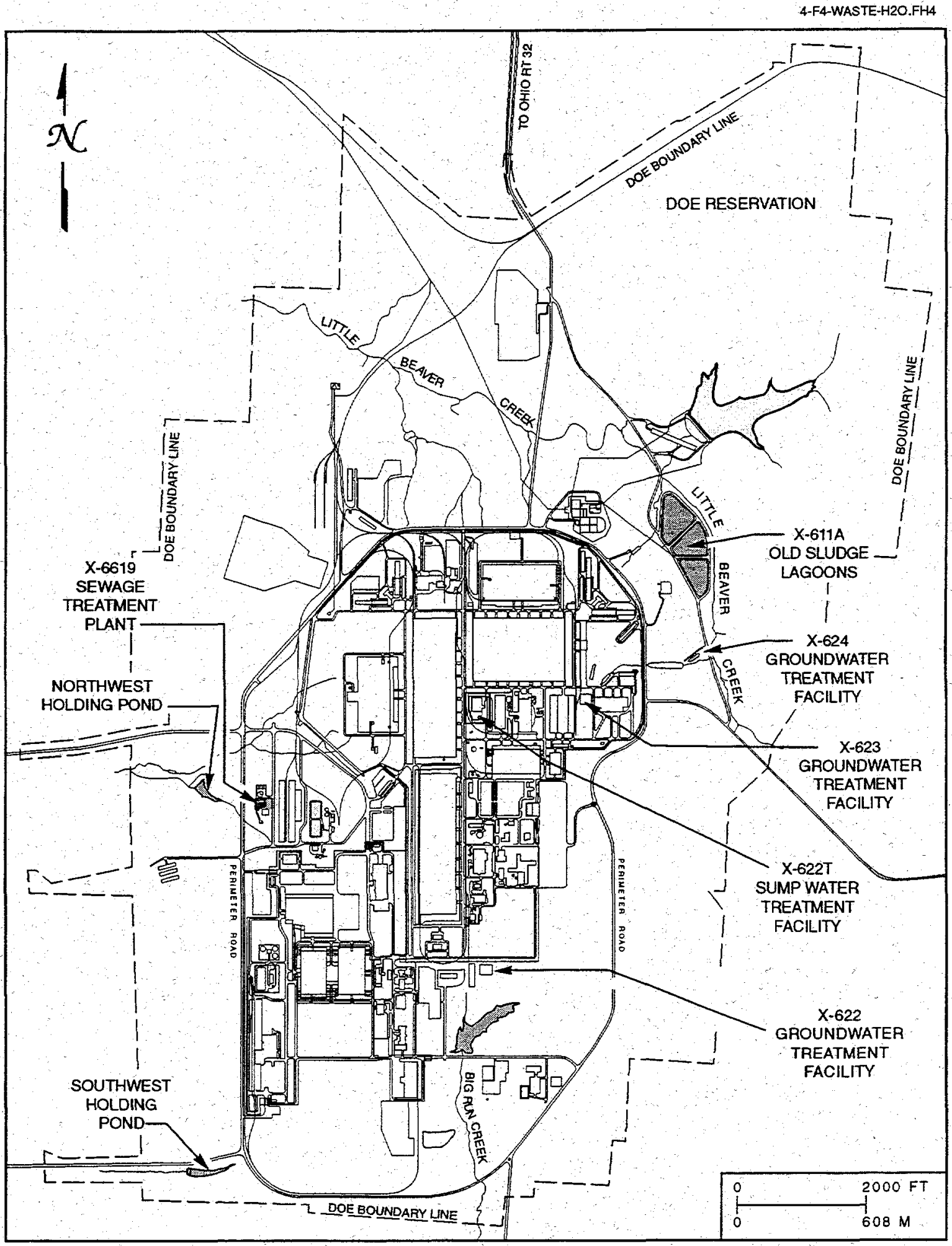

Fig 4.4. Major wastewater sources and systems at DOE/PORTS. 


\section{Background}

The quality of surface waters at DOE/PORTS is affected by wastewater discharges and groundwater transport of contaminants from land disposal of waste. Although bedrock characteristics differ somewhat among the watersheds of these surface waters, the observed differences in water chemistry are attributed to different contaminant loadings rather than geologic variation. Water quality, radioactivity, and flow measurements are made at a number of stations operated by DOE. Water samples are collected and analyzed at various intervals (weekly, monthly, etc.) for radiological and nonradiological parameters.

Liquid plant effluents are regulated by the NPDES permit, issued September 1, 1995, and discharged to surface streams that pass through the reservation to the Scioto River. A brief description of these discharge points, or outfalls, is provided in the following paragraphs. The locations of the NPDES-permitted outfalls that are the responsibility of DOE are shown in Figure 4.5.

NPDES 609 (X-624 carbon filtration facility-this outfall number was changed to 015 in the new permit) - This facility provides for removal of volatile organic compounds (VOCs) from contaminated groundwater originating from the X-701B plume interceptor trench. These groundwater interceptor trenches were constructed to control the migration of VOC-contaminated groundwater toward Little Beaver Creek. A flow diagram for outfall 609 is shown in Figure 4.6.

NPDES 606 (X-701E/X-623 carbon filtration facility-this outfall number was changed to 610 in the new permit)-These facilities (X-623 replaced the X-701E in June 1994) provide for removal of VOCs from contaminated groundwater originating from site remediation activities and from miscellaneous well development and purge waters. Treated water is discharged to the sanitary sewer and then to USEC outfall 003.

NPDES 607 (X-700 air stripper)-The X-700 air stripper was constructed to remove VOCs from contaminated groundwater originating from the X-701B site remediation activities. This outfall was removed from the new permit.

NPDES 608 (X-622 groundwater treatment facility - - This facility provides for removal of VOCs from contaminated groundwater originating from X-231B, X-749, and Peter Kiewit landfill site remediation activities.

NPDES 611 (X-611/X-705 sump water treatment facility)-This facility provides for the removal of VOC's from decontamination water from the X-705 decontamination facility. Treated water is discharged to the sanitary sewer then to USEC outfall 003.

NPDES 006 (X-611A north sludge lagoon), NPDES 007 (X-611A middle sludge lagoon), and NPDES 008 (X-611A south sludge lagoon)-These lagoons once received lime sludge from the plant water-softening process and are filled to capacity. The lagoons now receive water from rainfall. Discharges from these facilities are rare and occur only during periods of excessive rainfall. Flow diagrams for outfalls 006, 007, and 008 are shown in Figure 4.7.

NPDES 012 [X-2230M holding pond, formerly Gas Centrifuge Enrichment Plant (GCEP) 001]-The $\mathrm{X}-2230 \mathrm{M}$ holding pond provides a quiescent zone for settling of suspended solids, dissipation of chlorine, and containment of oil with effluent baffling. This outfall was renamed outfall 012 by the Ohio EPA on September 23, 1991.

NPDES 013 (X-2230N holding pond, formerly GCEP 002)-The X-2230N holding pond provides a quiescent zone for settling of suspended solids, dissipation of chlorine, and containment of oil with effluent baffling. This outfall was renamed outfall 013 by the Ohio EPA on September 23, 1991.

\section{4-6 Effluent Monitoring}




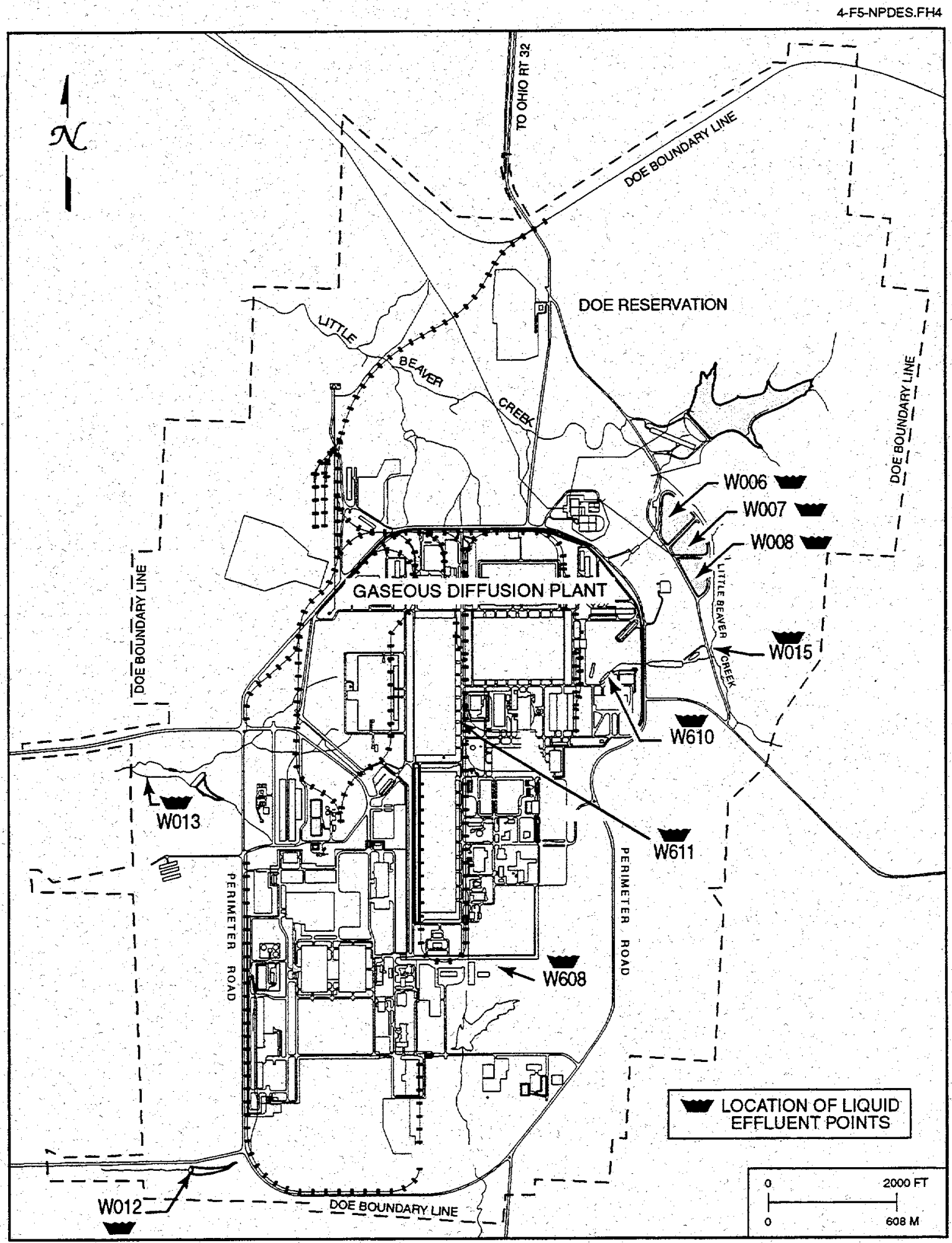

Fig 4.5. NPDES water sampling locations at DOE/PORTS. 


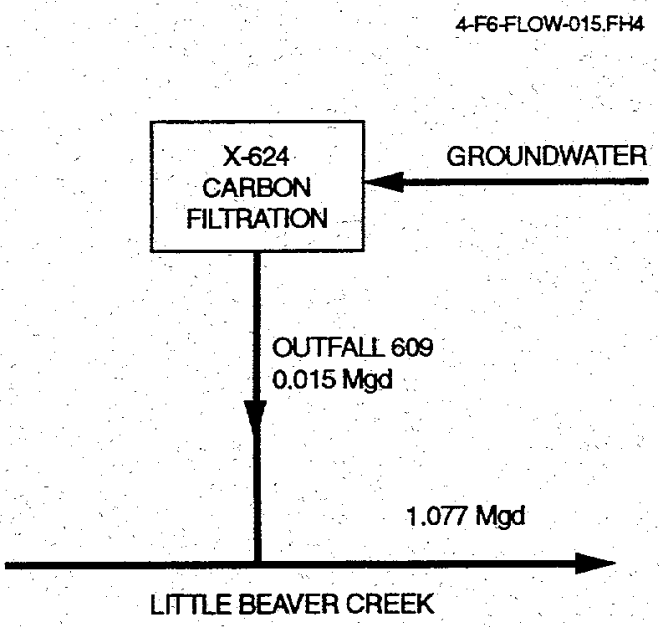

Fig. 4.6. Flow diagram for outfall 015 (X-624 carbon filtration facility).

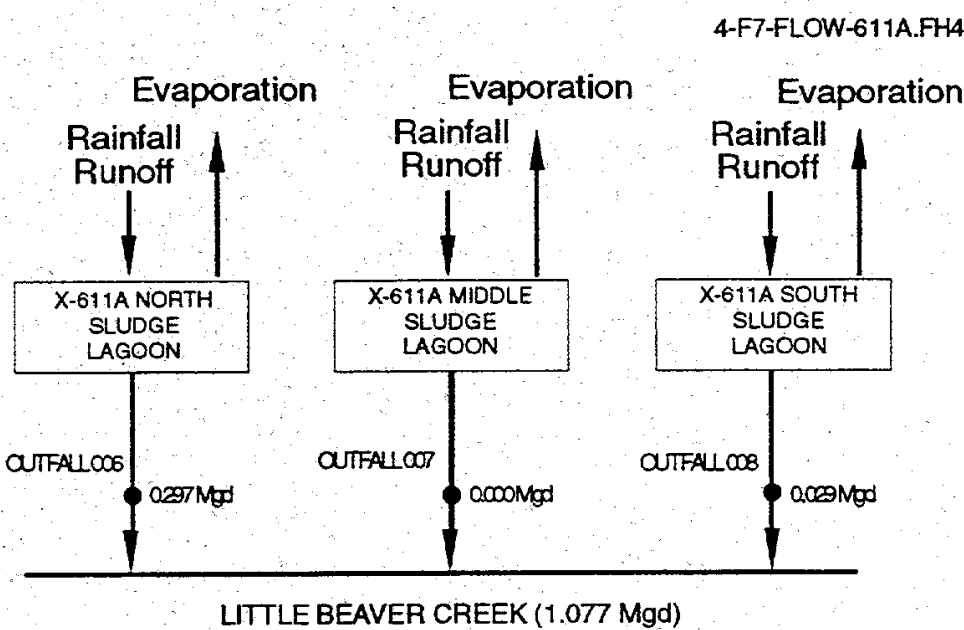

Fig. 4.7. Flow diagram for outfalls 006,007 , and 008 (X-611A north, middle, and south sludge lagoons).

NPDES 014 (holding pond not constructed, formerly GCEP 003)-A holding pond originally planned and designated as outfall 003 was not constructed because of significant changes in area topography. The Portsmouth NPDES permit issued September 23; 1991, limits discharges to this outfall to storm water only and requires no routine monitoring. This outfall was removed from the permit issued September 1, 1995.

A flow diagram for NPDES outfalls 012 and 013 is shown in Figure 4.8.

\section{Radiological Liquid Discharges}

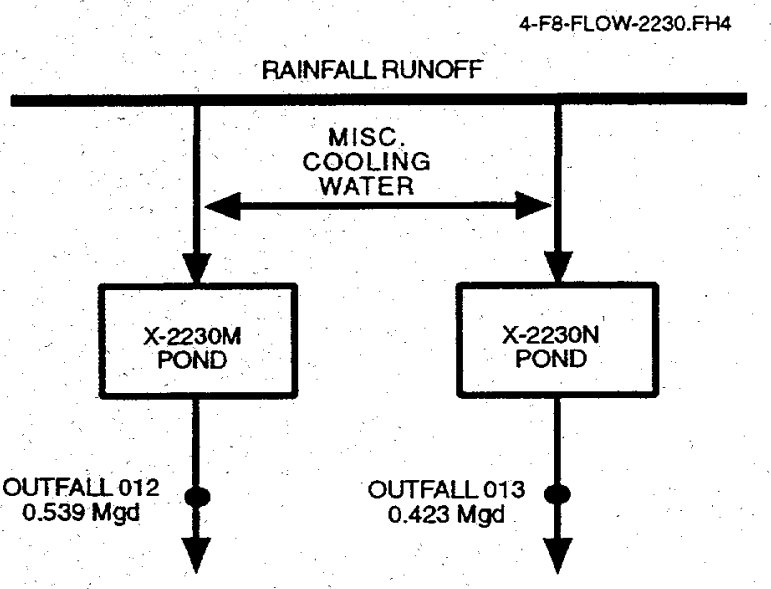

Fig. 4.8. Flow diagram for outfalls 012 and 013 (X-2230M holding pond and X-2230 N holding pond).

Virtually all radiological liquid discharges from DOE activities come from remediation activities. The exceptions are trace concentrations of naturally occurring uranium in storm water runoff. The locations of remediation activities are dispersed throughout DOE/PORTS and may be discharged from any of the NPDES outfalls.

\section{Rádiological Liquid Sample Collection and Analytical Procedure}

DOE external outfalls $(012,013$ and 015$)$ are monitored by taking grab samples in compliance with NPDES, Aliquots from these samples are analyzed for total uranium concentrations, gross alpha, gross beta, and ${ }^{99} \mathrm{Tc}$-beta radioactivity. The ratio of alpha activity to total uranium is used along with process data to calculate the proportions of the individual uranium isotopes. 


\section{Radiological Liquid Results}

Liquid radiological discharges from DOE/PORTS had no significant impact on public health or the environment. Total radionuclide discharges from DOE/PORTS sources in 1995 totaled $0.801 \mathrm{~kg}$. A total of $0.002 \mathrm{Ci}$ of uranium was discharged in 1995 from DOE/PORTS sources. All samples taken for technetium during 1995 from DOE sources were below the limit of detection. No unplanned releases to surface water occurred during 1995.

The secondary standard for multiple nuclides is that the sum of the fractional DCG values shall not exceed 1.0. In 1995, DOE/PORTS discharges remained well below the applicable DOE standard (100 mrem/ year) and far below the levels listed as safe by national and international regulatory bodies such as the Occupational Safety and Health Administration, the NRC, and the International Committee on Radiation Protection (5 rem/year).

\section{Nonradiological Liquid Discharges}

DOE/PORTS operations also release various nonradiological substances to surface waters. In addition, a shallow groundwater aquifer under DOE/PORTS discharges to local surface waters on all four sides of the plant, although not always within the reservation boundary.

\section{Regulatory Requirements}

Nonradiological discharges to surface waters are regulated by the DOE/PORTS NPDES permit issued under the authority of the Clean Water Act. The Ohio EPA has regulatory authority for the Clean Water Act at DOE/PORTS; however, the Ohio EPA did not become active in administering NPDES permits to federal facilities until early 1983 . In a letter dated May 25, 1983, from the Ohio EPA, DOE/PORTS was advised to begin sending monthly self-monitoring NPDES reports directly to the Ohio EPA beginning with the August 1983 report. A revision of the DOE/PORTS NPDES permit was issued on September 23, 1991, and additional modifications were issued on December 12, 1991; June 1, 1993; September 3, 1993; and April 1, 1994. This permit expired on July 29, 1994. In January 1994, DOE submitted an application for a new permit to the Ohio EPA. A new NPDES permit was issued for DOE outfalls and became effective September 1, 1995.

\section{Nonradiological Liquid Sample Collection and Analytical Procedure}

Sampling of nonradioactive constituents is regulated under the DOE/PORTS NPDES permit. Analyses are performed in accordance with 40 CFR 136.

\section{Nonradiological Liquid Results}

The 1995 NPDES compliance rate for DOE outfalls was $97 \%$. Compliance rates for individual parameters ranged from $92 \%$ to $100 \%$.

Data from the three discharge points from the X-611A lime sludge lagoons (NPDES 006, 007, and 008) indicated that there were two exceedences of the measured parameters, although the flow at these outfalls is too infrequent to calculate a useful compliance rate. In 1995, only 14 samples were obtained for all three outfalls.

At the X-2230M holding pond (NPDES 012), two exceedences of the total suspended solids (TSS) and two exceedences of oil and grease limits resulted in a compliance rate of $97 \%$. Exceedences were determined to be caused by heavy rainfall/snowmelt. The compliance rate for all other parameters was $100 \%$. 
Two exceedences of oil and grease limits at the X-2230N holding pond (NPDES 013) resulted in compliance rates of $92 \%$. The exceedences were attributed to heavy rainfall/snowmelt and high ambient temperatures. The compliance rate for all other parameters was $100 \%$.

The X-701E/X-623 carbon filtration facility (NPDES 606-now 610) had two exceedences of TCE effluent limits. The X-623 facility became operational in October 1995, and the exceedences are attributed to startup operations.

The X-700 air stripper (NPDES 607) was not used during 1995 and subsequently was removed from the permit.

At the X-622 groundwater treatment facility (NPDES 608), one exceedence of the monthly average concentration of 1,2-trans-dichloroethene resulted in a compliance rate of $92 \%$ for this parameter.

The X-624 carbon filtration facility (NPDES 609-now 015) had one TCE exceedence for a compliance rate of $97 \%$. 


\title{
5. Dose
}

\begin{abstract}
Potential impacts on human health from DOE/PORTS operations are calculated based on environmental monitoring and surveillance data. The maximum potential effective dose equivalent that a person living off site could receive from airborne radiological releases from DOE activities at the Portsmouth site is $0.005 \mathrm{mrem}$. This potential dose is less than the 1994 effective dose equivalent for DOE/PORTS $(0.066 \mathrm{mrem})$ and is well below the $10 \mathrm{mrem} /$ year limit set by the U.S. Environmental Protection Agency, the $100 \mathrm{mrem} /$ year limit set by DOE, and the $300 \mathrm{mrem} / \mathrm{year}$ (approximate) dose the average person in the United States receives from natural sources of radiation. Chemical releases were also well below applicable standards, and dose calculations show that any potential chemical doses to the public would be minute and would not have any adverse health effects.
\end{abstract}

\section{INTRODUCTION}

Previous sections of this report characterize and quantify radiological and chemical releases from DOE/PORTS operations during 1995 (Section 4). This section evaluates the potential impacts (i.e., dose) on human health based on the data presented in Section 4.

\section{APPLICABLE REGULATIONS}

\section{Radiological Regulations}

Airborne releases of radionuclides from DOE facilities are regulated by the USEPA under the Clean Air Act and NESHAP. These regulations set an annual dose limit of $10 \mathrm{mrem} / \mathrm{year}$ to any member of the public as a result of airborne releases from DOE nuclear facilities, as well as setting performance standards for demonstrating compliance with the dose limit. Airborne radionuclide discharges are also regulated, along with all other atmospheric pollutants, under the Ohio permit-to-operate regulations. However, Ohio does not yet have standards governing radionuclide emission limits and therefore defers to the federal NESHAP regulations.

DOE regulates radionuclide emissions to all environmental media through DOE Orders 5400.1 , General Environmental Protection Program, and 5400.5, Radiation Protection of the Public and the Environment. DOE Order 5400.5 sets an annual dose limit of 100 mrem/year to any member of the public. The DOE limit includes all radionuclide releases from a facility, unlike the NESHAP limit.

\section{Chemical Regulations}

Airborne discharges of chemical agents are regulated under the Ohio permit-to-operate regulations issued under the state equivalent of the Clean Air-Act. Enforceable limits on emissions listed in these permits are based on maintaining normal ambient air concentrations within ambient air quality standards (i.e., the limits are not directly enforceable on individual sources). 
Liquid discharges are regulated by the NPDES permit issued under the Clean Water Act. Enforceable limits in the permit are based on maintaining appropriate water quality in receiving streams.

\section{DOSE CALCULATION}

Small quantities of radionuclides were released to the environment from DOE/PORTS operations during 1995. This section summarizes estimates of the potential consequences of the releases and describes the methods used to make the estimates.

\section{Radiological Dose Calculation}

\section{Terminology}

Most consequences associated with radionuclides released to the environment are caused by interactions between human tissue and various types of radiation emitted by the radionuclides. These interactions involve the transfer of energy from radiation to tissue, possibly resulting in tissue damage. Radiation may come from radionuclides outside the body (in or on environmental media or objects) or from radionuclides deposited inside the body (by inhalation, ingestion, and, in a few cases, absorption through the skin). Exposures to radiation from radionuclides outside the body are called external exposures; exposures to radiation from radionuclides inside the body are called internal exposures. This distinction is important because exter$\mathrm{nal}$ exposure occurs only as long as a person is near the external radionuclide; simply leaving the area of the source will stop the exposure. Internal exposure continues as long as the radionuclide remains inside the body.

A number of specialized units have been defined for characterizing exposures to ionizing radiation. Because the damage associated with such exposures results primarily from the deposition of radiant energy in tissue, the units are defined in terms of the amount of incident radiant energy absorbed by tissue and of the biological consequences of that absorbed energy. These units include the following:

- Absorbed dose - a physical quantity that defines the amount of incident radiant energy absorbed per unit mass of an irradiated material; its unit of measure is the rad. The absorbed dose depends on the type and energy of the incident radiation and on the atomic number of the absorbing material.

- Dose equivalent - a quantity that expresses the biological effectiveness of an absorbed dose in a specified human organ or tissue; its unit of measure is the rem. The dose equivalent is numerically equal to the absorbed dose multiplied by modifying factors that relate the absorbed dose to biological effects. In this report, the term "dose equivalent" is often shortened to "dose."

- Effective dose equivalent (EDE) - a risk-equivalent dose equivalent that can be used to estimate healtheffect risks to exposed persons; it is a weighted sum of dose equivalents to specified organs. The weighing factors and identification of these specific organs have been published by the International Commission on Radiological Protection (ICRP 1977, ICRP 1978).

- Committed (effective) dose equivalent (CEDE) - the total (effective) dose equivalent that will be received over a specified time period (in this document calculations are based on a 50-year period) because of radionuclides taken into the body during the current year.

- Collective committed (effective) dose equivalent - the sum of committed (effective) dose equivalents to all individuals in an exposed population. The unit of measure is the person-rem. The collective dose is also frequently called the "population dose."

- Dose conversion factor - the dose equivalent received from exposure to a unit quantity of a radionuclide by a specific exposure pathway. Two types of dose conversion factors exist. One type gives the commit- 
ted dose equivalent (rem) resulting from intake (by inhalation and ingestion) of a unit activity [1.0 $\mu \mathrm{Ci}$ ( $37 \mathrm{~Bq})]$ of a radionuclide. The second type gives the dose equivalent rate $(\mathrm{mrem})$ per unit activity [1.0 $\mu \mathrm{Ci}(37 \mathrm{~Bq})]$ of a radionuclide in a unit $\left(\mathrm{cm}^{3}\right.$ or $\left.\mathrm{cm}^{2}\right)$ of an environmental compartment (air or ground surface).

- Total effective dose equivalent (TEDE) - the sum of the EDE for external exposures and the CEDE for internal exposure.

\section{Dose Calculation for Airborne Radionuclides}

Characterizing the consequences of radionuclides released to the atmosphere by site activities during 1995 was accomplished by calculating EDEs to the maximally exposed person (a hypothetical individual who is assumed to reside at the most exposed point on the plant boundary) and to the entire population (approximately 918,000) residing within 50 miles of the plant. Dose calculations were made using the Clean Air Act Assessment Package-88 (CAP-88) of computer codes (Beres 1990), which was developed under sponsorship of the USEPA for use in demonstrating compliance with NESHAP concerning radionuclides (40 CFR 61). This package contains the most recently approved version of the AIRDOS-EPA and DARTAB computer codes and of the ALLRAD88 radionuclide data file. The AIRDOS-EPA computer code implements a steadystate, Gaussian plume, atmospheric dispersion model to calculate concentrations of radionuclides in the air and on the ground; it uses NRC Regulatory Guide 1.109 food-chain models to calculate radionuclide concentrations in foodstuffs (e.g., vegetables, meat, and milk) and subsequent intakes by individuals. The concentrations and human intakes are used by the USEPA's latest version of the DARTAB computer code to calculate EDEs to humans from radionuclides released to the atmosphere. The dose calculations use the dose conversion factors contained in the ALLRAD88 data file.

Radionuclide release data were modeled for three release points. The radionuclide release inventory is detailed in Section 4, "Effluent Monitoring." Meteorological data used in the calculations consisted of joint frequency distributions of wind direction, wind speed, and atmospheric stability that were prepared from data collected during 1995 at the 40-m station on the DOE/PORTS meteorological tower. Rainfall during 1995 was 41.3 in., the average air temperature was $53^{\circ} \mathrm{F}$, and the average mixing layer height was $6,562 \mathrm{ft}$.

The dose calculations assumed that each person remained unprotected, at home (actually outside the house) during the entire year and obtained food according to the rural pattern defined in the NESHAP background documents (USEPA $1989 \mathrm{~b}$ ). This pattern specifies that $70 \%$ of the vegetables and produce, $44.2 \%$ of the meat, and $39.9 \%$ of the milk consumed by each person are produced in the local area (e.g., in a home garden). The remaining portion of each food is assumed to be produced within 50 miles of DOE/PORTS. For collective EDE estimates, production of beef, milk, and crops within 50 miles of DOE/PORTS was calculated using the state-specific production rates provided with CAP-88.

\section{Dose Calculation for Waterborne Radionuclides}

Water is sampled at all plant outfalls and in the receiving streams. Sample results for the Scioto River show no significant difference in radionuclide concentrations between upstream and downstream locations (see Section 4, "Effluent Monitoring").

\section{Dose Calculation for Radionuclides in Other Environmental Media}

The CAP-88 computer codes calculate doses from ingestion of meat, milk, and vegetables containing radionuclides that were released to the atmosphere. Using the conservative food consumption pattern de- 
scribed in the previous sections, about $62 \%$ of the maximum individual EDE and $81 \%$ of the collective EDE result from ingestion of foodstuffs.

\section{Calculation of Radiological Dose to Aquatic Biota}

DOE Order 5400.5, Chapter II, sets an absorbed dose rate limit of $1 \mathrm{rad} /$ day to native aquatic organisms. To demonstrate compliance with this limit, absorbed dose rates to crustacea, mollusks, and fish were calculated using the CRITR2 computer code and measured (annual average) radionuclide concentrations in the Scioto River. CRITR2 estimates dose rates from internally deposited radionuclides, from immersion in water, and from sediment irradiation (Baker and Sold at 1993).

\section{Chemical Dose Calculation}

Varying amounts of chemicals were released to the environment from DOE/PORTS operations during 1995. This section contains estimates of potential human exposure to these chemicals and compares the exposures to acceptable levels of exposure as defined by federal standards and regulations.

\section{Terminology}

Terms pertinent to discussion of chemical exposure include the following:

- Acceptable daily intake (ADI)-intake of a chemical (measured in milligrams per day) that is not anticipated to result in any adverse health effects over a lifetime of exposure. ADIs are calculated from several different federal standards and regulations.

- Ambient air quality standard (AAQS) - national or state standard for maximum concentration of an airborne pollutant that is not expected to adversely affect the public health (primary AAQS) or the public welfare (secondary AAQS).

- Chronic daily intake (CDI) -intake of a chemical (expressed in milligrams per day) from drinking $2 \mathrm{~L}$ ( 2 qt) of surface water per day.

- Maximum contaminant level (MCL) - maximum concentration legally allowable in drinking water under USEPA national interim primary and national primary drinking water regulations that apply to all community or public water systems.

- Maximum-contaminant-level goal-maximum concentration desirable in drinking water. USEPA national secondary drinking water regulations that apply to public water systems.

- NPDES - permit program that includes effluent standards, monitoring requirements, and conditions for discharge.

- Reference dose - an estimate of the daily exposure to the human population, including sensitive individuals, that is likely to be without an appreciable risk of harmful effects during a lifetime.

\section{Dose Calculation for Waterborne Chemicals}

The USEPA has set ADI standards for some chemicals in the form of maximum contaminant levels and maximum-contaminant-level goals (in milligrams per liter), which were converted to ADI values by multiplying by the average daily adult water intake of $2 \mathrm{~L} \mathrm{(} 2 \mathrm{qt})$. Drinking water regulations and standards apply to community or public water systems and thus are conservative when applied to surface water.

\section{5-4 Dose}


For chemicals for which maximum contaminant levels or maximum-contaminant-level goals were not available, ADIs were calculated from oral reference doses. These values are available from the USEPA Integrated Risk Information System (USEPA 1991). For noncarcinogenic chemicals, daily exposure to the reference dose (in milligrams per kilograms per day) should result in no adverse effect over a lifetime. ADIs were calculated from reference doses by multiplying by $70 \mathrm{~kg}$, the average human body weight.

Outfalls are not readily accessible to the general public; therefore, ingestion of water directly from outfalls is unlikely. Although it is possible for a member of the public to ingest water from either Big Beaver Creek or Big Run Creek, both of these water bodies run through active agricultural operations (i.e., farms and cattle pastures) along their entire length between DOE/PORTS and the Scioto River and are classified as unsuitable for use as potable water sources because of agricultural runoff. Consequently, the first realistic location for a member of the public to be routinely exposed to liquid discharges is the Scioto River. In fact, there are no identified drinking water intakes in the Scioto River downstream of DOE/PORTS either.

Sampling data for eight metals and two organic chemicals are available for NPDES outfall stations. (Not all chemicals were measured at each outfall.) Annual average values of the sampling data (in micrograms per liter) were multiplied by $2 \mathrm{~L}$ to estimate routine daily intake levels. Much of the sampling data for individual chemicals were reported as "less-than" $(<)$ values, indicating that concentrations were below the limits of detection of the analytical methods used. Because average sample concentrations were reported as less-than values, the CDIs are also reported as less-than values. The CDIs were compared with the ADIs to establish whether ingestion of water could result in an exposure above the ADI. CDIADI ratios of less than 1 indicate an acceptable level of risk; CDU/ADI ratios greater than 1 could indicate an unacceptable risk or the need for further study.

\section{Calculation of Direct Exposure to Chemicals}

Direct exposure to chemicals does not represent a likely pathway of exposure at DOE/PORTS. For airborne releases, concentrations off-site are too small to present problems through the skin exposure pathway. For water releases, outfalls are generally located within areas of the site that are not readily accessible to the general public. Although exposures for consumption of drinking water at the discharge sites were calculated, public exposure to water from the area of the discharge on a daily basis is highly unlikely.

\section{DOSE CALCULATION RESULTS}

\section{Radiological Dose Results}

The Radiation Exposure Information Reporting System (REIRS) report is an electronic file created annually to comply with DOE Order 5484.1. This report contains exposure results for all monitored individuals at DOE/PORTS, which includes visitors, with a positive exposure during the previous calendar year. The 1995 REIRS Report indicated that there were no visitors with a positive exposure.

Federal regulation 10 CFR 835 requires that a visitor report be sent to all individuals visiting DOE/ PORTS who have been monitored for external and/or internal exposure to radiation or radioactive material: Any member of the public exposed to radiation or radioactive material during direct on-site access at a DOE site or facility shall not exceed 100 mrem TEDE in a year.

The average TEDE in 1995 for all employees and subcontractors was $0.87 \mathrm{mrem}$, with the highest TEDE being 69 mrem. 


\section{Airborne Radionuclide Results}

The maximum potential EDE to an off-site individual from 1995 radiological releases from DOE/ PORTS is 0.005 mrem, which is well below the 10-mrem NESHAP limit applicable to DOE/PORTS and the approximate 300 -mrem dose per year that the average individual in the United States receives from natural sources of radiation. It is unlikely that any one person would be exposed to maximum doses from both airborne and liquid effluents because the points of maximum exposure are on opposite sides of the plant. Furthermore, no one is known to draw drinking water from the Scioto River downstream of the plant.

The collective EDE to the entire population around DOE/PORTS in 1995 was 1.2 person-rem, which is a minute fraction of the approximately 276,000 person-rem that this population received from natural sources of radiation during 1995. The collective EDE to the nearest community, Piketon, was calculated to be approximately 0.02 person-rem. 


\section{Groundwater}

\section{Abstract}

The purpose of groundwater monitoring at DOE/PORTS is to characterize the hydrogeology and monitor groundwater quality at the plant and its environs. More than 600 monitoring wells are used to track the flow of groundwater and to measure any contaminants present both on- and off-site. Groundwater monitoring extends to surface water that receives direct input from groundwater sources. Off-site sampling is conducted to assess the effects of the Portsmouth operations on nearby public and residential water supplies.

\section{INTRODUCTION}

Groundwater monitoring activities include effluent surveillance monitoring, synoptic groundwater level measurements, and other types of monitoring of (1) RCRA units, (2) solid waste disposal units, (3) special investigation or monitoring units, (4) groundwater treatment units, and (5) RFI quadrant location units.

\section{GROUNDWATER HYDROLOGY}

A portion of precipitation accumulates as groundwater by soaking into the ground, infiltrating soil and rock. The accumulation of groundwater in pore spaces in sediments and bedrock creates sources of usable water, which flows in response to external forces. Groundwater may eventually reappear at the surface in springs, swamps, stream and river beds, or pumped wells. Thus, the primary input to groundwater is recharge from rainwater, and the output of groundwater is discharge to springs, swamps, rivers, streams, and wells.

Surface water percolates downward into soil through the pore spaces between sediment grains. The smaller the pore spaces, the slower the flow of water through sediment. Permeability is the ease with which water moves through the pore spaces and cracks in a given material and is largely determined by the volume and size of the pore spaces and how well connected the pore spaces are.

As water infiltrates the earth, it travels down through the vadose, or unsaturated, zone. Here the pore spaces are filled partly with water and partly with air. Water moving down through the unsaturated zone will eventually reach the saturated zone, where the pore spaces are completely filled with water. The boundary between unsaturated and saturated zones is known as the water table, the elevation of which generally follows, in subtle form, the contour of the surface topography. Springs, swamps, and beds of streams and rivers are outcrops of the water table.

The unit of measurement for permeability most commonly used in the study of hydrology or hydrogeology is hydraulic conductivity, which indicates the speed (or velocity) at which groundwater flows through a particular kind of rock or soil. The water pressure at a particular location, called the hydraulic head, is for the most part a result of the elevation of the water table at that location. The hydraulic head varies from location to location because the elevation of the water table is not level but normally mimics the surface of the ground, although in a subdued fashion. Variations in the hydraulic head create a hydraulic gradient and are the driving force for movement of groundwater through the saturated zone. In addition to hydraulic conductivity, the actual groundwater velocity at a particular location depends on the hydraulic gradient and the porosity of the earth materials at that location. 
The flow of groundwater and the position of the water table may be complicated by variations in the hydraulic conductivity. Because earth materials have greatly varying permeability, groundwater flowing through subsurface strata does not travel at a constant rate or without impediment. Strata that transmit water easily (such as those composed primarily of sand) are called aquifers, and strata that restrict water movement (such as clay and shale layers) are called aquitards. An aquifer with an aquitard lying above and below it is a confined aquifer.

G-F1-MON-WELLFH4

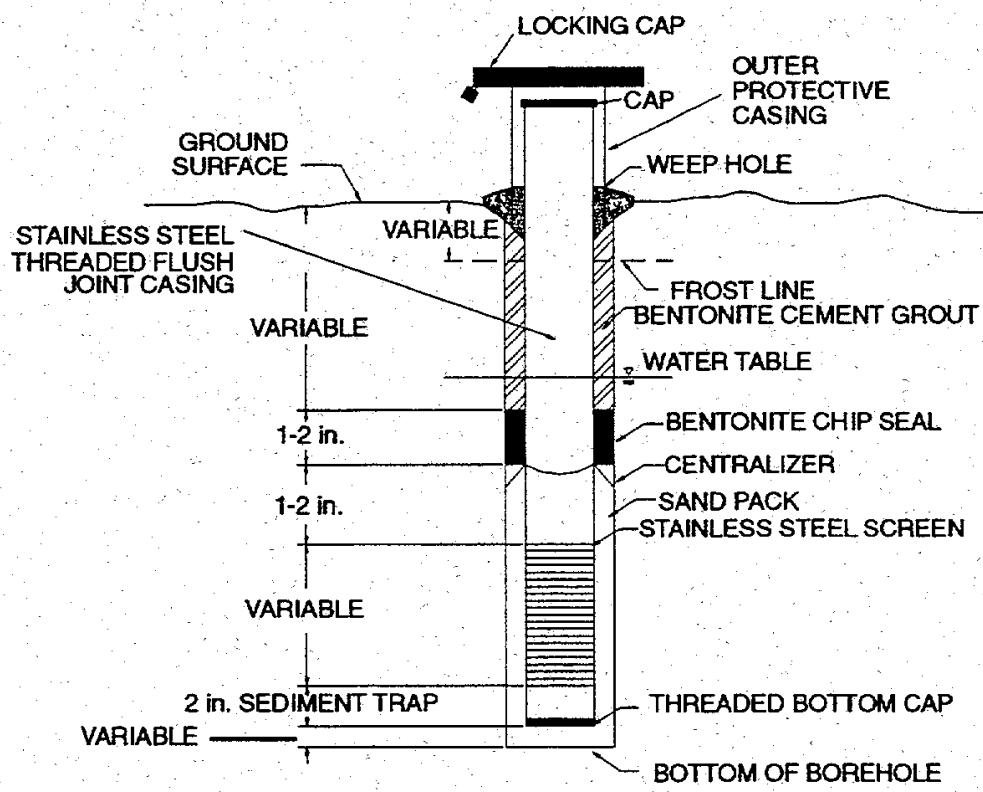

Fig. 6.1. Typical monitoring well construction.

Groundwater moves through aquifers in a downgradient direction. Because hydraulic head is not solely a function of elevation, downgradient is not necessarily synonymous with downhill. The downgradient direction has a horizontal and a vertical component, just as a household drain moves wastewater both horizontally and vertically, seeking the lowest point of exit. Aquitards deflect groundwater movement just as drainpipe walls control the direction of wastewater movement. In an aquifer constrained by aquitards, such as horizontal clay layers, the downgradient direction tends to be more horizontal than vertical.

Water infiltrating surficial soils is the primary pathway for potentially hazardous substances to enter an aquifer. Substances placed in the soil may be dissolved in rainwater, which moves them downward through the unsaturated zone to the water table. The water then flows downgradient toward a discharge point.

Monitoring wells are used extensively to assess the effect of operations on groundwater quality, generally to determine the effect of a specific site on nearby groundwater quality. Wells positioned to intercept groundwater flowing away from a site are called downgradient wells, and wells placed to intercept groundwater before it flows under a site are called upgradient wells. Any contamination of downgradient wells not present in upgradient wells at a site may be assumed to be a product of that site. Wells are drilled to various depths in the saturated zone downgradient of the area to be monitored. At the screen zone, the well casing is perforated to allow water to enter the well. Thus, the screen zone refers to the zone of subsurface strata where water is being sampled by the well. Figure 6.1 illustrates the construction of a monitoring well and the relationship between the screen zone and water elevation for wells screened below the water table. Water rises in the well casing to equilibrate with the hydraulic head of the water surrounding the screen zone of the well. The elevation of the water in the well is measured to determine the hydraulic head of the water in the monitored zone. By comparing water levels in adjacent wells screened in the same zone, the hydraulic gradient can be determined and thus the horizontal direction of groundwater flow can be predicted. Only wells screened in the same zones are considered when determining the horizontal gradient; wells screened above and below an aquitard can have different hydraulic heads, defining a vertical gradient.

Vertical groundwater movement is controlled by the hydraulic conductivity of the aquitards and the relative difference in hydraulic head of the water on either side of an aquitard. Vertical gradients can be determined by comparing the water levels between adjacent wells screened on either side of an aquitard. If the

\section{6-2 Groundwater}


water levels in deeper wells are higher than those in shallower wells, the vertical component of flow is upward. Conversely, if the water levels in deeper wells are lower than those in shallower wells, the vertical component of flow is downward.

Vertical and horizontal groundwater flow directions are determined in part by the permeability and continuity of geologic strata. To effectively monitor the movement of groundwater and any hazardous constituents it may contain, hydrogeologists at DOE/PORTS have undertaken many detailed studies of the geology of the strata beneath the site.

\section{GEOLOGICAL AND HYDROGEOLOGICAL SETTING}

DOE/PORTS is located near the northwestern boundary of the Appalachian Plateau physiographic province. The uppermost rock units in this region were deposited in an inland sea during the Paleozoic era. At the end of the Paleozoic era (approximately 230 million years ago), the region was uplifted and gently folded to form a shallow basin that parallels the Appalachian Mountains. Subsequent erosion of the uplifted sediments produced the deeply dissected; knobby terrain that characterizes the region. Glaciation during the Pleistocene era ( 2 million to 25,000 years ago) affected this region by changing the directions of streams, causing lakes to form and filling in valleys with lake and river sediments.

\section{Topography}

DOE/PORTS occupies an upland area of southern Ohio with an average land surface elevation of $670 \mathrm{ft}$ above mean sea level. The plant site sits in a mile-wide abandoned river valley $120 \mathrm{ft}$ above the Scioto River located to the west of the plant site. (See Figure 6.2).

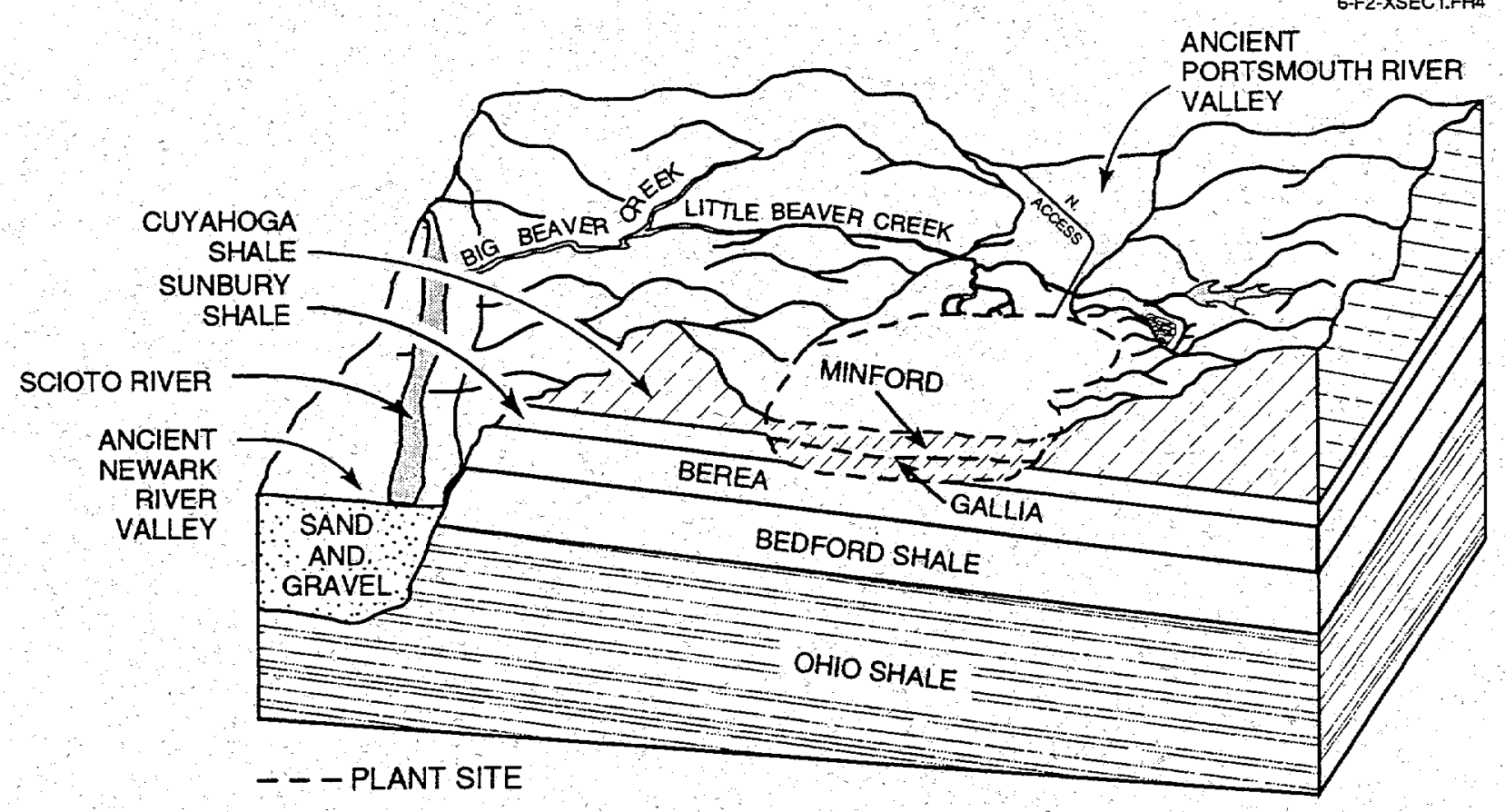

Fig. 6.2. Schematic cross section of DOEPORTS. 
The predominant landform in the site area is the relatively level, broad, filled valley, which is oriented north to south and is bounded on the east and west by deeply dissected ridges or low-lying hills. Another significant landform is the small valley formed by Little Beaver Creek; this creek flows in a northwesterly direction across the middle of the site, just north and east of the main industrialized area.

Other significant landforms consist of several small valleys formed by streams that have cut into the relatively level unconsolidated deposits under DOE/PORTS. One of these valleys is that of a northwestwardly flowing stream, the west drainage ditch, which is near the west-central area of the plant. Two more streams are located in the southern portion of the industrialized area. In the southeast portion of the site, a southerly flowing stream, Big Run Creek, is situated in a relatively broad, gently sloping valley. An unnamed southwesterly flowing stream in the southwest portion of the site has formed a narrow, steep-walled valley.

In much of the industrialized area of DOE/PORTS, the original topography was modified for construction of buildings and other facility components.

\section{Stratigraphy}

The surficial material over much of the industrialized area of DOE/PORTS is fill material removed from the higher elevations of the site. The material is composed of varying proportions of the unconsolidated geologic materials that are described in the following paragraphs (see Table 6.1).

Table 6.1. Stratigraphy in the vicinity of DOE/PORTS.

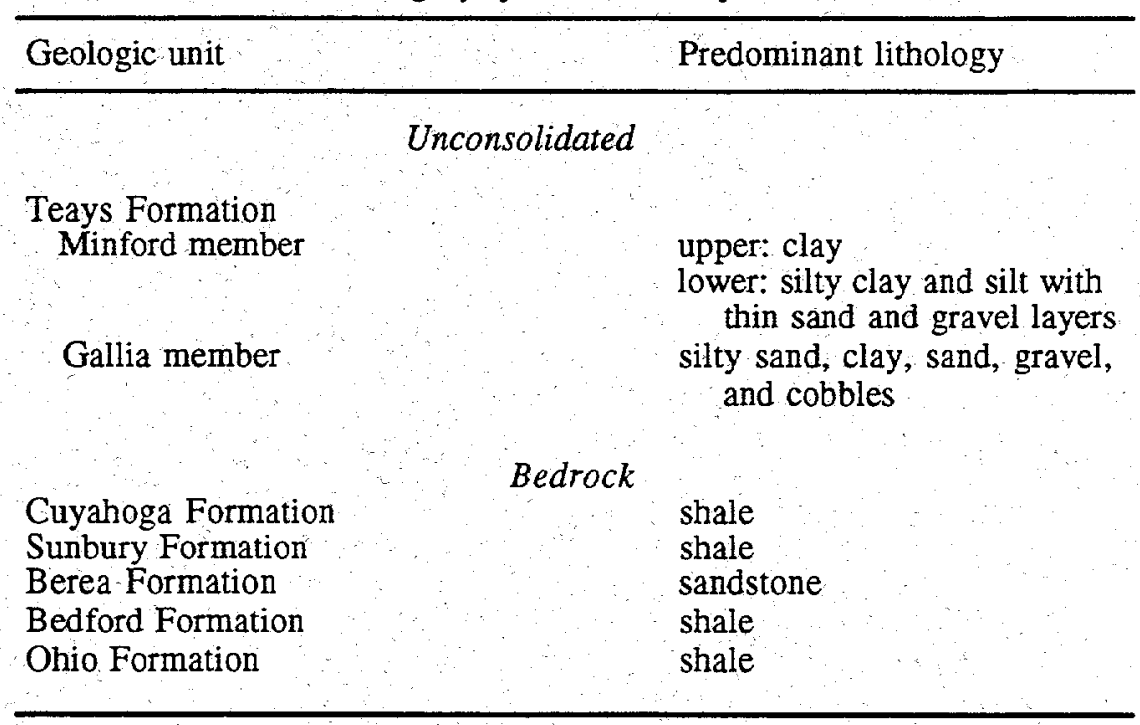

The geologic materials of DOE/PORTS consist of unconsolidated lacustrine (lake) and fluvial (river) deposits that overlie the regional consolidated bedrock. The unconsolidated deposits were deposited during the recent glaciation. Rather than being deposited directly by the glaciers, the deposits were formed in dammed, preexisting river valleys and in valleys created by glacial runoff, features peripheral to the glaciers themselves. The unconsolidated deposits beneath DOE/PORTS are not continuous with the unconsolidated deposits in the Scioto River valley to the west. A bedrock ridge forms the western valley wall that separates the two groups of unconsolidated deposits. The consolidated bedrock deposits formed in a broad, continental sea about 400 million years ago.

The unconsolidated Teays Formation consists of two members: the Minford clay and silt and the Gallia sand. The consolidated bedrock is composed of the Cuyahoga, Sunbury, Berea, and Bedford Forma- 
tions. In the vicinity of DOE/PORTS, the Cuyahoga, Sunbury, and Bedford Formations are predominantly shales, whereas the Berea Formation is predominantly sandstone.

The Minford member of the Teays Formation is a lacustrine deposit consisting of two distinct units: an upper clay unit with silt and sand, and a lower silt unit composed of silty clay and very fine to fine-grained sand. Both units are continuous across DOE/PORTS. Across much of the facility, only the basal part of the clay unit is saturated, whereas the lower silt unit is usually completely saturated.

The Gallia member of the Teays Formation, commonly referred to as the Gallia sand, is a fluvial deposit underlying the Minford member at approximately $25 \mathrm{ft}$ below ground surface. The Gallia sand is discontinuous across the site and typically consists of red-brown, clayey, medium to coarse sand and gravel; it overlies bedrock and has a mean thickness of slightly more than $3 \mathrm{ft}$. The Gallia sand is usually poorly sorted, often containing silt and clay as well as numerous pebble-sized rock fragments. The Gallia sand is commonly absent near bedrock highs, such as the bedrock valley walls. The coarser sands and gravels usually occur near the base of the unit and were deposited as point bar and/or channel lag deposits. Contact between the Minford and Gallia members varies from gradational to sharp.

The Cuyahoga Formation, commonly referred to as the Cuyahoga shale, is the uppermost bedrock formation in the geographic area and is a moderately hard, thinly laminated shale with numerous sandstone laminations. The Formation is not found beneath the industrial portion of DOE/PORTS but does form hills surrounding the facility.

The Sunbury Formation, commonly referred to as the Sunbury shale, is the uppermost bedrock formation (where present) beneath the industrial portion of DOE/PORTS. The unit is composed of a competent, black, carbonaceous, fissile shale that is approximately $20 \mathrm{ft}$ thick on the eastern portion of the facility and is absent on the western portion.

The Berea Formation, commonly referred to as the Berea sandstone, is continuous beneath the industrial portion of DOE/PORTS. The Berea sandstone underlies the Sunbury shale on the eastern portion of the facility and underlies the unconsolidated Minford and Gallia members of the Teays Formation on the western portion of the facility. The Berea sandstone is approximately $30 \mathrm{ft}$ thick. A thin zone (1 to $3 \mathrm{in}$.) of sulfide mineralization occurs at the interface between the Sunbury shale and the Berea sandstone. The upper portion of the Berea Formation, approximately $20 \mathrm{ft}$ thick, is composed of a light-gray, hard, thickly bedded, fine-grained sandstone; the lower portion, approximately $10 \mathrm{ft}$ thick, has numerous interlayered shale laminations and is similar to the underlying Bedford Formation

The Bedford Formation, commonly referred to as the Bedford shale, is continuous beneath DOE/ PORTS and is also found everywhere beneath the Berea sandstone. The formation averages $100 \mathrm{ft}$ in thickness and consists of thinly bedded shale with interbeds and laminations of hard, gray, fine-grained sandstone and siltstone. In three boreholes that penetrated the Bedford, the sandstone interbeds at $570 \mathrm{ft}$ above the national geodetic vertical datum of 1929 (NGVD) were saturated with naturally occurring petroleum hydrocarbons.

\section{Geologic History}

Prior to glaciation, the major drainage system in southern Ohio was the Teays River system. The Teays flowed northwest and passed about $4.8 \mathrm{~km}$ (three miles) north of the area now occupied by DOE/ PORTS. Immediately north of the plant site, Big Beaver Creek occupies a portion of the valley of the extinct Teays River.

The Portsmouth River, a tributary of the Teays, flowed north across the area that is now occupied by DOE/PORTS. In that same area, the Portsmouth River eroded a valley through the Cuyahoga shale and the 
Sunbury shale and in localized areas may have eroded into the Berea sandstone. The Sunbury was eroded into a wedge that diminishes to the west and exposes the Berea bedrock on the western half of the site. As the Portsmouth River meandered through the valley, sand and gravel were deposited; these fluvial deposits formed the Gallia member of the Teays Formation. Subsequently, an advancing glacier blocked the northwestward flow of the Teays River, and a glacial lake, Lake Tight; filled the valleys of the Teays River and its tributaries. The Minford member of the Teays Formation was formed at this time as lacustrine silts and clays accumulated in the lake bed. These deposits are in two distinct stratigraphic units. The deepest unit is composed of relatively clean silts, indicative of shallow lake levels or overbank deposits; the upper unit is composed of a series of laminated clays that probably were deposited as Lake Tight increased in size and depth.

Eventually, Lake Tight overflowed its banks and initiated the "deep stage drainage"; the most significant deep stage stream in southern Ohio was the south-flowing Newark River. The Newark occupied the course of the present day Scioto River from the cities of Chillicothe to Portsmouth. As the glacier retreated, meltwater moved through the Newark River valley and partially backfilled it with outwash. The current drainage for the region, the Scioto River, is situated on a thick layer of outwash in the valley formed by the Newark River.

The geologic structure of the area is simple. The Mississippian strata dips gently to the east at approximately $30 \mathrm{ft} /$ mile $\left(0.3^{\circ}\right)$. A schematic cross section of the DOE/PORTS reservation and adjacent areas is presented in Figure 6.2. No known major or minor faults are in the area; however, two distinct joint sets (i.e., fractures) are present in outcrops of the Sunbury and Berea. Azimuths for joint sets are $\mathrm{N} 65^{\circ} \mathrm{E}$ and $\mathrm{N} 25^{\circ} \mathrm{W}$. Bedding plane fractures also have been identified.

Surface soils are composed of loess and colluvium and more recently deposited alluvium. During the initial grading of the site prior to plant construction, elevated areas were removed and used to fill depressions. In most cases the fill is indistinguishable from undisturbed Minford deposits.

\section{Groundwater Hydrogeology}

The unconsolidated and bedrock systems at DOE/PORTS each include a low- and high-permeability unit. The Gallia sand and the Berea sandstone are the transmissive units at DOE/PORTS. The Gallia sand has the highest hydraulic conductivity and is the primary groundwater migration pathway. The hydraulic conductivity of the Minford silt member is somewhat lower than that of the Gallia sand but is much higher than that of the Minford clay member. The Gallia sand and the saturated portion of the Minford silt member act as a single hydrogeologic unit: The Berea sandstone is a regional geologic unit, and its relatively high hydraulic conductivity makes it the second lithologic unit with transmissive properties. The Minford clay member and the Sunbury shale exhibit lower hydraulic conductivities. The Minford clay member forms a semiconfining layer for the Gallia sand. The Sunbury shale, where more than $4 \mathrm{ft}$ thick, forms a confining layer for the Minford silt member and the Berea sandstone.

Based on numerous laboratory tests, the average hydraulic conductivity for the Minford clay is $2.3 \times 10^{-4} \mathrm{ft} /$ day and for the Minford silt is $4.3 \times 10^{-3} \mathrm{ft}$ day. The vertical hydraulic conductivities of Minford clay and Minford silt are approximately an order of magnitude lower than their horizontal hydraulic conductivities. The hydraulic conductivity determined by single-well tests of the Gallia sand ranged from 0.11 to $150 \mathrm{ft} /$ day with a mean value of $3.4 \mathrm{ft} /$ day. The hydraulic conductivity of the Sunbury shale, based on modeling, ranges from $1.6 \times 10^{-4}$ to $9.6 \times 10^{-4} \mathrm{ft} /$ day. The vertical hydraulic conductivity of the Sunbury shale is an order of magnitude lower than its horizontal hydraulic conductivity. The hydraulic conductivity determined by single-well tests of the Berea sandstone ranges from $4.5 \times 10^{-3}$ to $15 \mathrm{ft} /$ day with a mean value of $0.16 \mathrm{ft} /$ day. The higher hydraulic conductive results are from areas where the Sunbury shale is absent. 
The Bedford shale is the lowest confining layer in the groundwater flow system because of its massive thickness and shale composition.

The Minford silt member, the Gallia sand, and the Berea sandstone make up the uppermost aquifer. The Gallia sand is the primary aquifer, or water-bearing zone, because it has the highest hydraulic conductivity, but it is not present everywhere. The Minford silt member and the Berea sandstone have somewhat lower hydraulic conductivities than the Gallia sand. Because it is locally present, the Gallia sand is a local waterbearing unit.

Based on water-level measurements during August 1993, the average elevation of the Gallia sand potentiometric surface at DOE/PORTS ranges from more than $660 \mathrm{ft}$ above NGVD at the center of the facility to $620 \mathrm{ft}$ above NGVD on the south, east, and west and to $600 \mathrm{ft}$ above NGVD on the north. This results in a site-wide average water table depth of approximately 10 to $15 \mathrm{ft}$ below the surface. Many factors can affect water table depth at a particular location, including seasonal variations resulting from increased or decreased precipitation, topography, land use, thickness of the upper clay portion of the Minford member, presence of storm drains, and operation of groundwater remediation processes. Future construction activities or additional groundwater treatment facilities may also affect water table depth.

As previously discussed, DOE/PORTS is located in a valley. The industrialized portion of DOE/ PORTS is located in the central portion of the valley. Four creeks or drainage channels drain the facility: Little Beaver Creek drains the eastern and northern portion; Big Run Creek and the unnamed drainage channel drain the southern, southwestern, and western portion; and the west drainage ditch drains the western portion. All ultimately discharge to the Scioto River. All four creeks and drainage ditches dissect the unconsolidated Minford silt and clay and Gallia sand, the bedrock-forming Sunbury shale (where present), and the Berea sandstone before exiting the Portsmouth site. Because the elevation of the water table is above the elevations of the creeks and drainage ditches, groundwater discharges to them as base flow.

Groundwater flow-divides exist beneath DOE/PORTS where the groundwater flows toward one or another of these discharge locations. The groundwater divides in the Gallia sand and the Berea sandstone are located in approximately the same place. The locations vary throughout the year because of climatic conditions. Generally, the Berea sandstone and Gallia sand groundwater divides coincide. Migration of the groundwater divides in the Berea sandstone shows less seasonal variation than that of the Gallia sand.

The north-south trending groundwater divide for the Gallia sand runs from the southern DOE/PORTS boundary between Big Run Creek and the unnamed drainage ditch toward the southern part of the X-326 building, where it follows the east side of the $X-330$ building. This drainage divide ends near the northern side of the X-330 building. Groundwater flow north of this drainage divide is to the north toward Little Beaver Creek. The north-south trending drainage divide for the Berea sandstone is slightly displaced to the west of the Gallia groundwater drainage divide.

The east-west trending groundwater divide for the Gallia sand runs from the northwest corner of the $X-7725$ building toward the central portion of the $X-326$ building and then to the northern part of the $X-100$ building. The east-west trending groundwater divide for the Berea sandstone runs from the northwest corner of the X-7725 building toward the north side of the $X-326$ building and then runs due east.

There are over 600 monitoring wells and piezometers (an instrument used to measure fluid pressure) at DOE/PORTS. Of these, approximately 100 monitoring wells and 13 surface water monitoring locations are sampled routinely, while approximately 300 monitoring wells are used for quarterly water level measurements or non-routine sampling activities. 


\section{USES OF GROUNDWATER IN THE VICINITY}

Groundwater is used as a domestic, municipal, and industrial water supply in the vicinity of DOE/ PORTS. Most municipal and industrial water supplies in Pike County are developed from the Scioto River Valley buried aquifer, which is where the largest towns and virtually all industry are located. Groundwater in the Berea sandstone and Gallia sand formations that underlie the Portsmouth site are not used as domestic, municipal, or industrial water supplies. Domestic water supplies are obtained from either unconsolidated deposits in preglacial valleys, major tributaries to the Scioto River Valley, or from fractured bedrock encountered during drilling.

DOE/PORTS is the largest industrial user of water in the vicinity and obtains its water from the $X$ $608, X-605 G$, and X-6609 water supply well fields, which are next to the Scioto River south of Piketon. The wells tap the Scioto River Valley buried aquifer. Total groundwater production averages 13 million gal/day.

Contaminants in the groundwater beneath DOE/PORTS do not affect the quality of the water in the Scioto River Valley buried aquifer.

\section{APPLICABLE MONITORING STANDARDS}

Many state and federal laws and regulations, as well as DOE orders and directives, establish standards and requirements governing groundwater monitoring activities at DOE/PORTS. State and federal regulations, DOE orders, and guidance documents relevant to groundwater monitoring at DOE/PORTS are described in the following sections.

\section{State and Federal Laws and Regulations}

RCRA, with its accompanying regulations, is the primary federal law establishing groundwater monitoring requirements, although CERCLA also contains certain requirements. The USEPA promulgates and enforces federal groundwater monitoring regulations. DOE/PORTS is located in USEPA Region V, which is headquartered in Chicago and encompasses the midwestern states.

The Ohio EPA promulgates and enforces state groundwater monitoring regulations, which must be consistent with federal regulations. DOE/PORTS is located within the jurisdiction of the Ohio EPA Southeast District Office in Logan, Ohio. The Ohio EPA is authorized to manage the RCRA and Hazardous and Solid Waste Amendment (HSWA) program in Ohio, excluding the authority to issue interim status corrective orders. The Ohio EPA has primary enforcement authority for RCRA requirements within Ohio.

State and federal regulations governing groundwater monitoring at DOE/PORTS are briefly described in the following sections.

\section{Title 40, Code of Federal Regulations, Part 265, Subpart F; Part 264, Subpart F; and Corresponding State Regulations}

RCRA groundwater monitoring requirements have been established in phases. Initial requirements, or interim status requirements, are prescribed by Title 40, Code of Federal Regulations, Part 265 (40 CFR 265) and Ohio Administrative Code (OAC) 3745-65-90 through -94. Interim status groundwater monitoring requirements are applied to all authorized interim status hazardous waste management units. Basically, the 
40 CFR 265 standards require that a facility (1) monitor for detection of contaminants in groundwater;

(2) prepare a groundwater quality assessment plan to be implemented in the event contaminants are discovered; and (3) monitor to assess the extent of contamination, as required by the groundwater quality assessment plan. Groundwater monitoring requirements are to continue through the post-closure period of the facility. Upon receipt of their final administrative permit, issued pursuant to a RCRA permit application, facilities must meet the more stringent standards prescribed in 40 CFR 264, Subpart F, and OAC 3745-54-90 through 99.

\section{Closure and Post-Closure Care Requirements}

Closure and post-closure care include requirements for groundwater monitoring. Federal closure and post-closure interim status requirements are found in 40 CFR 265, Subpart G. Corresponding state regulations are in OAC 3745-66. Final standards, which apply upon issuance of the final administrative permit, are found in 40 CFR 264, Subpart G. Corresponding state regulations are in OAC 3745-55.

\section{Underground Storage Tank (UST) Requirements}

Groundwater monitoring is required in certain instances for USTs. Technical standards and corrective action requirements for owners and operators of USTs can be found in 40 CFR 280, Subparts D, E, F, and G. Corresponding state regulations can be found in OAC 1301:7-9-07, 7-9-12,7-9-13, and 7-9-14.

\section{Solid Waste Requirements}

Ohio Administrative Code 3745-27-10 and 3745-29-10 require groundwater monitoring for releases at solid waste disposal sites. The code includes detailed sampling and analysis plan requirements and requirements for monitoring well construction and installation. State solid waste groundwater monitoring requirements parallel those for hazardous waste.

\section{DOE Orders}

DOE orders contain basic legal requirements for DOE programs and operations. Several DOE orders contain references to groundwater protection or monitoring. Contaminated groundwater shall be managed or decontaminated under the procedures and requirements of DOE Order 5480.4 and the 5400 series. A list of the orders and a summary of these requirements follow.

\section{1, General Environmental Protection Program}

DOE Order 5400.1 states that "it is DOE policy to conduct the Department's operations in compliance with the letter and spirit of applicable environmental statutes, regulations, and standards." The order recognizes that where USEPA, state, and local environmental agencies "clearly exercise environmental protection authority through permitting and compliance administrative procedures applicable to DOE, they establish and regulate required performance for environmental protection." 
DOE Order 5400.1 defines environmental monitoring as consisting of effluent monitoring and environmental surveillance and establishes detailed requirements for both a groundwater protection management program and a groundwater monitoring program. The Groundwater Protection Program (GWPP) Management Plan must be reviewed annually and updated every three years. The plan should include

- documentation of the groundwater regime with respect to quantity and quality;

- design and implementation of a groundwater monitoring program to support resource management and comply with applicable environmental laws and regulations;

- a management program for groundwater protection and remediation, including specific Safe Drinking Water Act, RCRA, and CERCLA action;

- a summary and identification of areas that may be contaminated with hazardous substances;

- strategies for controlling sources of these contaminants;

- a remedial action program that is part of the site CERCLA program required by DOE Order 5400.4 ; and

- decontamination and decommissioning and other remedial programs contained in DOE directives.

A groundwater monitoring program is to be developed as part of any environmental monitoring plan and for the groundwater protection management program. The groundwater monitoring program shall conform with RCRA standards, where appropriate. Monitoring for radionuclides is to be conducted in accordance with DOE orders.

In addition to these general requirements, DOE Order 5400.1 also contains recommendations regarding monitoring well construction and location, groundwater sampling frequency, sampling and analytical methods, sample sizes, and methods of sample preservation.

\subsection{A, Environmental Compliance Issue Coordination}

This order requires coordination of environmental issues that are of significance to DOE, including groundwater protection.

\section{3, Hazardous and Radioactive Mixed Waste Management}

Under this order, DOE must manage hazardous and radioactive mixed waste according to the requirements of RCRA, including those of 40 CFR 264 and 265. "RCRA applies to the extent it is not inconsistent with the Atomic Energy Act (AEA). The radioactive component of radioactive mixed waste is subject to the requirements of DOE 5820.2A."

\section{4, Comprehensive Environmental Response, Compensation, and Liability Act Program}

This order requires that corrective actions under RCRA or state laws be performed in a manner that satisfies CERCLA requirements, where appropriate. 


\section{5, Radiation Protection of the Public and the Environment (to be replaced by 10 CFR 834, proposed)}

The purpose of this order is to protect the public and the environment from risk of radioactive contamination. The order establishes (1) a standard of high quality for DOE monitoring and surveillance programs, (2) authorized contamination limits for release of property, and (3) as-low-as-reasonably-achievable considerations. The order mandates that drinking water criteria be consistent with 40 CFR 141, "National Interim Primary Drinking Water Regulations." Derived concentration guidelines, or the concentration of radionuclides in water that under conditions of continuous exposure for one year by one exposure mode would result in an EDE of $100 \mathrm{mrem}$, are established. The order limits stormwater and sanitary sewer discharge of radioactive effluents to groundwater. Finally, the order states that long-term management of groundwater shall be in accordance with legally applicable federal and state standards.

\section{4, Environmental Protection, Safety, and Health Protection Standards}

This order specifies statutory and regulatory provisions that apply to DOE programs and operations.

\subsection{A, Management of Low-Level Waste}

This order establishes that environmental monitoring associated with low-level and mixed radioactive waste management activities shall be conducted in accordance with DOE Order 5400.1 and may include groundwater monitoring. The monitoring program must be able to measure

- operational effluent releases,

- migration of radionuclides,

- disposal unit subsidence, and

- changes in disposal facility and disposal site parameters that may affect long-term site performance.

Moreover, the monitoring program must be capable of detecting changing trends in time to apply appropriate corrective action measures.

This order also establishes policies and guidelines for decontamination and decommissioning of DOE facilities. Programs must follow all applicable federal, state, and local requirements.

Finally, this order requires that a waste management plan outline be prepared that discusses, among other items, the environmental monitoring programs at individual waste management facilities.

\section{Ohio Consent Decree and USEPA Administrative Consent Order}

The Ohio Consent Decree entered into on August 29, 1989, and the RCRA, Section 3008(h), Administrative Consent Order entered into with USEPA Region V on September 29,1989, outline requirements and schedules for the RFI at DOE/PORTS. These documents include specific dates and deliverables that must be 


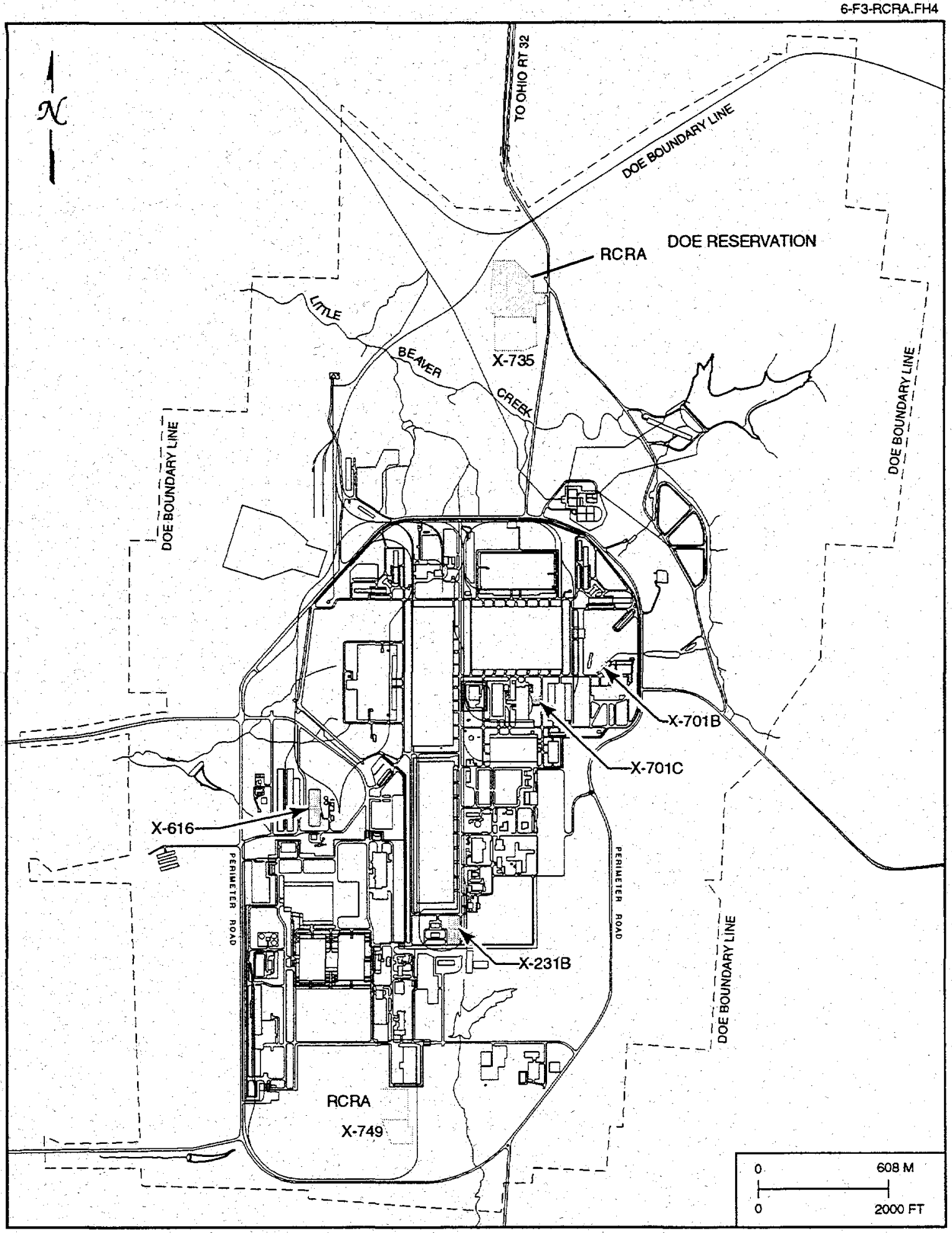

FIG. 6.3. RCRA interim status land disposal unit locations at DOEPORTS. 
followed throughout the RFI, the CMS, and corrective measures implementation (CMI). In addition, these documents include (1) specific interim remedial measures (IRMs): a site-wide environmental audit, TCE removal from groundwater at $X-701 B$, collection and analysis of a runoff sample at $X-749 ;$ (2) changes in environmental management practices, development of a PCB spill cleanup plan, and modifications of the site contingency plan and waste tracking system; (3) completion of groundwater quality assessments (GWQAs) at $\mathrm{X}-701 \mathrm{~B}, \mathrm{X}-749, \mathrm{X}-231 \mathrm{~B}$, and X-616.

Under the USEPA Administrative Consent Order, DOE/PORTS is to conduct a groundwater investigation to characterize any plumes of contamination at the facility. The language of the order parallels language of 40 CFR 264, Subpart F, and OAC 3745-54-90 through -99, requiring that groundwater protection standards be established for any groundwater contaminants found. The order also lists the four RCRA interim status units as hazardous waste disposal and storage areas. In addition, it identifies the X-231B, X-616, and X749 facilities as SWMUs.

The Ohio Consent Decree acknowledges receipt of the X-701B, X-749, X-231B and X-616 GWQA, as required under 40 CFR 265, Subpart F, and OAC 3745-55-90 through $-65-94$, and requires that a hydrogeologic investigation be conducted as part of the site investigation to determine the present and potential extent of groundwater contamination. Long-term disposition of contaminants will be evaluated when the investigation is complete. The decree labels the four RCRA interim status units as hazardous waste treatment, storage, and disposal areas but includes only X-701B in its list of waste units.

Both of these documents will serve as major sources of information and guidance throughout the RFI, CMS, and CMI. At this time, directives stipulated by both documents are consistent with groundwater investigations conducted at DOE/PORTS in response to the federal and state regulations and DOE orders. As such, the monitoring strategies presented in the following section will be limited to the specific regulations and/or DOE orders.

\section{Guidance Documents}

The RCRA Groundwater Monitoring Technical Enforcement Guidance Document (USEPA 1989a) and the Technical Guidance Manual for Hydrogeologic Investigations and Groundwater Monitoring (Ohio EPA 1995) are the applicable guidance documents used by DOE/PORTS GWPP.

\section{GROUNDWATER MONITORING AT DOE/PORTS}

DOE/PORTS has six RCRA interim status units (see Figure 6.3) at which groundwater monitoring is specified in 40 CFR 265.93, Subparts F and $G$, and OAC sections 3745-65 and 3745-66. Under these regulations, detection monitoring is performed at units where there has been no statistically significant exceedence

of threshold levels of groundwater indicator parameters at downgradient wells. These parameters are listed in Table 6.2. In the event of statistically significant exceedence of these parameters at downgradient wells, the groundwater contaminant plume associated with the unit is characterized during a GWQA, and assessment monitoring is performed on a quarterly basis.

Detection monitoring is being performed at two units: (1) the X-735 RCRA landfill and (2) the X$701 \mathrm{C}$ neutralization pit. Assessment monitoring is performed at four units: (1) the X-701B holding pond, (2) the $X-231 B$ southwest oil biodegradation plot, (3) the X-616 chromium sludge surface impoundments, and (4) the X-749 contaminated materials disposal facility (RCRA and industrial portions). 
Table 6.2. Analyte analysis required for groundwater monitoring at RCRA units, the industrial landfills, surface water locations, off-site locations, and the $X-701 C$ neutralization pit at DOE/PORTS.

\begin{tabular}{|c|c|c|c|c|c|c|c|c|c|}
\hline \multirow[t]{2}{*}{ Analyte } & \multicolumn{7}{|c|}{ Monitoring location } & \\
\hline & $X-701 B^{a}$ & X-749ab & $\mathrm{X}-231^{\mathrm{B} a}$ & $x-616=$ & $\mathrm{X}-735 a b$ & $\begin{array}{c}\text { Surface } \\
\text { water }\end{array}$ & Off-site & $\mathrm{X}-701 \mathrm{C}$ & $\mathrm{X}-749 \mathrm{~A}$ \\
\hline
\end{tabular}

Volatile organic compounds (Method 8240)

Acetone

Benzene

Bromodichloromethane

Bromoform

Bromomethane

2-butanone

Carbon disulfide

Carbon tetrachloride

Chlorobenzene

Chlorodibromomethane

Chioroethane

Chloroform

Dichlorobenzenes

1,1-dichloroethane

1,2-dichloroethane

1,1-dichloroethene

1,2-dichloroethene (cis/trans)

Ethyl benzene

Freon-113

Freon-114

4-methyl-2-pentanone

1,1,2;2-tetrachloroethane

Tetrachloroethene

Toluene

1,1,1-trichloroethane

1,1,2-trichloroethane

Trichloroethene

Trichlorofluoromethane

Vinyl chloride

Xylenes

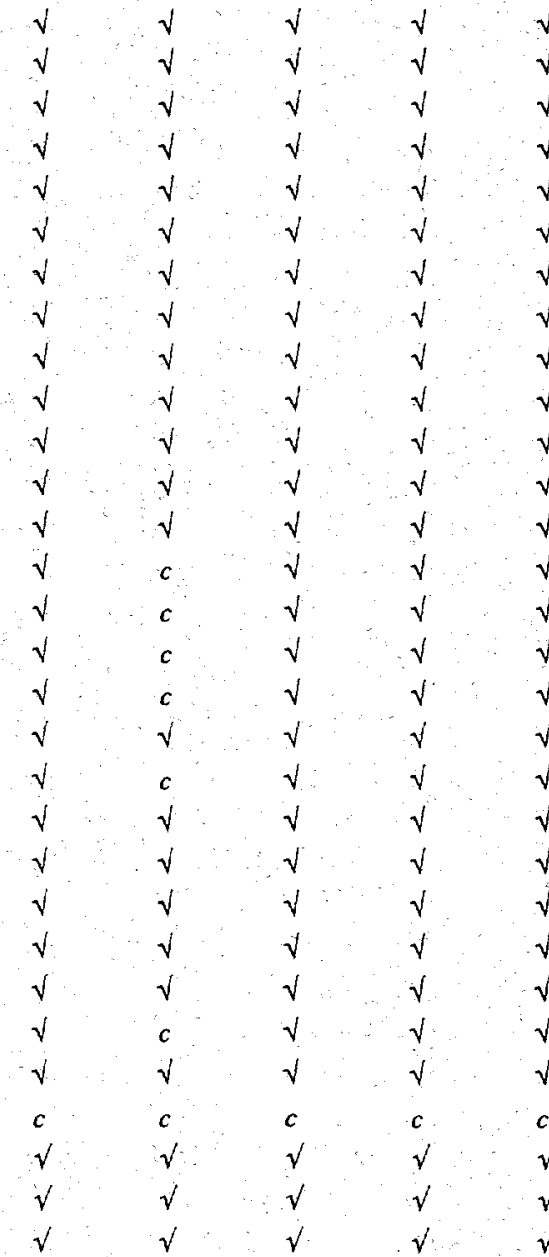

Radionuclide parameters

Gross alpha

Gross beta

Total uranium

Technetium beta

Transuranics

Isotopic uranium

$\begin{array}{lll}\sqrt{ } & \sqrt{ } \\ \sqrt{ } & \sqrt{ } \\ \sqrt{ } & \sqrt{ } \\ \sqrt{ } & \sqrt{ } \\ \sqrt{ } & \sqrt{ } \\ \sqrt{ } & \sqrt{ }\end{array}$

$\begin{array}{lllll}\sqrt{ } & \sqrt{ } & \sqrt{ } & \sqrt{ } \\ \sqrt{ } & \sqrt{ } & \sqrt{ } & \sqrt{ } \\ \sqrt{ } & \sqrt{ } & \sqrt{ } & \sqrt{ } \\ \sqrt{ } & \sqrt{ } & \sqrt{ } & \sqrt{ } \\ \sqrt{ } & & \sqrt{ } & \sqrt{ } \\ \sqrt{ } & & \sqrt{ } & \sqrt{ }\end{array}$

$\begin{array}{ll}\sqrt{ } & \sqrt{ } \\ \sqrt{ } & \sqrt{ } \\ \sqrt{ } & \sqrt{ } \\ \sqrt{ } & \sqrt{ }\end{array}$


Table 6.2. Analyte analysis required for groundwater monitoring at RCRA units, the industrial landfills, surface water locations, off-site locations, and the $X-701 C$ neutralization pit at DOE/PORTS (continued).

Analyte

Monitoring location

$\mathrm{X}-701 \mathrm{~B} a \mathrm{X}-749 a b$ X-231Ba X-616a X-735ab surface off-site $\mathrm{X}-701 \mathrm{C}$ W-749A

Metals

Arsenic

Barium

Cadmium

Chromium

Copper

Iron

Lead

Magnesium

Manganese

Mercury

Nickel

Potassium

Selenium

Silver

Sodium

Zine

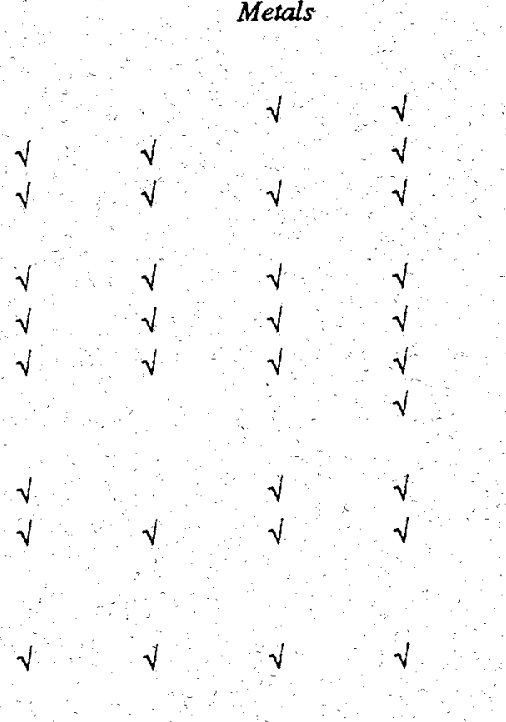

Ammonia

Nitrate

Nitrite

Chloride

Calcium

Sulfates

Phosphorus

Phenols

$\mathcal{J}$
$\sqrt{ }$
$\sqrt{ }$
$\sqrt{ }$
$\sqrt{ }$
$\sqrt{ }$
$\sqrt{ }$
$\sqrt{ }$
$\sqrt{ }$
$\sqrt{ }$
$\sqrt{ }$
$\sqrt{ }$
$\sqrt{ }$
$\sqrt{ }$
$\sqrt{ }$

Other chemical parameters

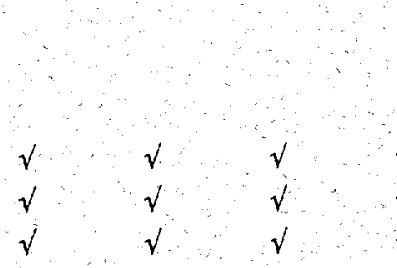

$\vdots$
$\sqrt{ }$
$\sqrt{ }$
$\sqrt{2}$

$\sqrt{ }$
$\sqrt{ }$
$\sqrt{ }$
$\sqrt{ }$
$\sqrt{ }$

Other physical paramesers

Total dissolyed solids

Total organic carbon

Chemical oxygen demand

Total alkalinity

Turbidity

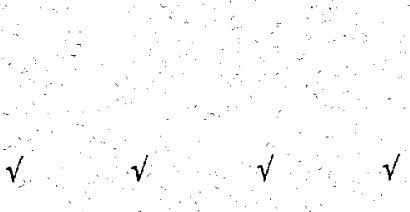

$\begin{array}{llll}\sqrt{ } & \sqrt{ } & \sqrt{ } \\ \sqrt{ } & \sqrt{ } & \sqrt{ } \\ \sqrt{ } & \sqrt{ } & \sqrt{ }\end{array}$

aRCRA unit.

bSolid Waste landfills

cPrimary volatile organic compounds of concern. 


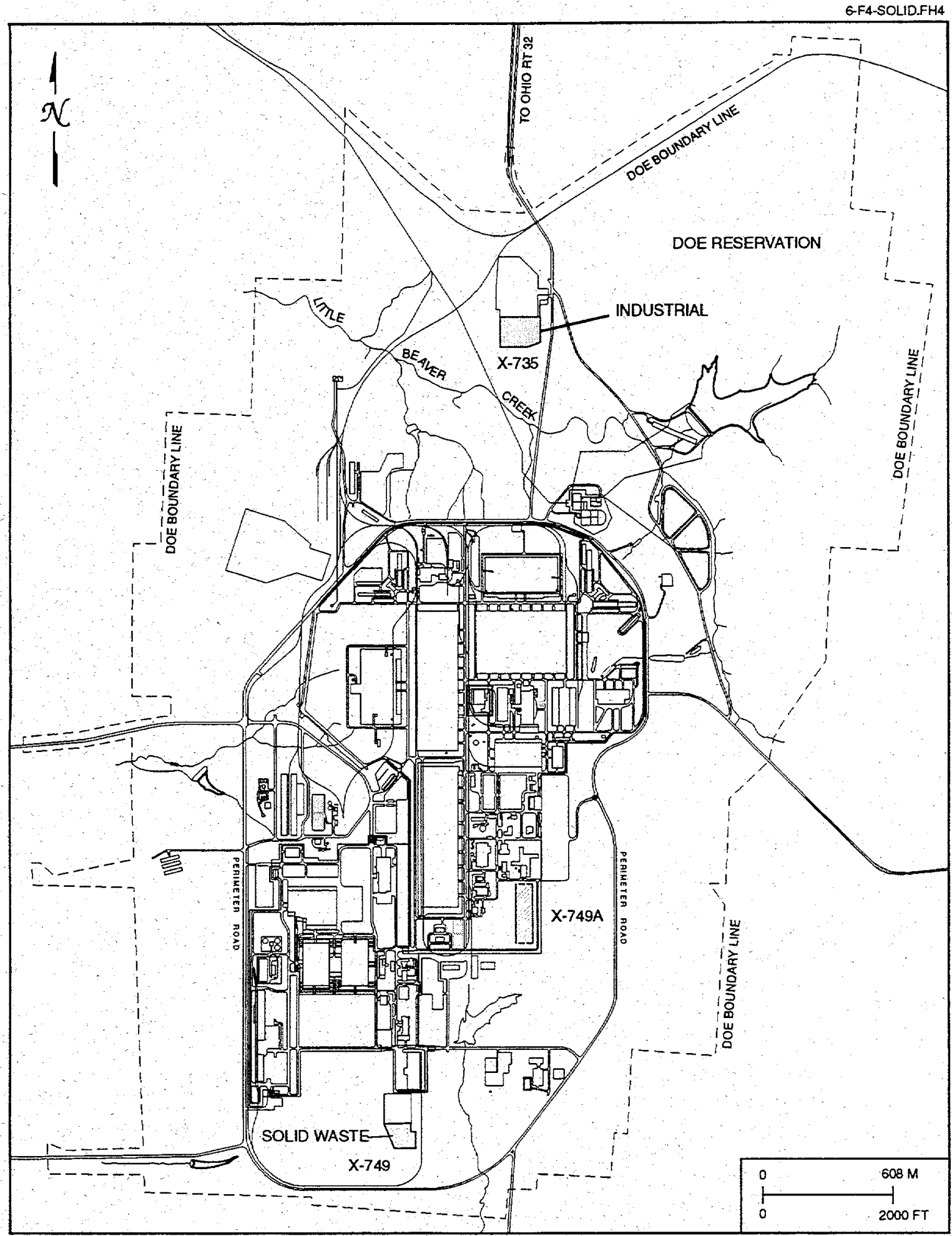

FIG. 6.4. Solid waste land disposal unit locations at DOE/PORTS. 
In addition to the RCRA interim status monitoring program, the solid waste regulations in OAC sections 3745-27 and 3745-29 require detection monitoring for the solid waste landfill units (see Figure 6.4): $X-749$ A classified materials disposal facility, X-735 industrial landfill, and X-749 contaminated materials disposal facility (southern portion). Because it is already included in the RCRA assessment monitoring program, detection monitoring required at the $X-749$ solid waste landfill is not being conducted.

The surveillance monitoring program at DOE/PORTS consists of perimeter exit pathway monitoring, off-site sampling, DOEJPORTS water supply well field sampling, and baseline monitoring. The purpose of perimeter exit pathway monitoring is to assess the effect of DOE/PORTS on regional groundwater quality and quantity. The off-site sampling and DOE/PORTS water supply well field sampling provide information to document any effect of DOE/PORTS operations on nearby residential and public water supplies. Baseline monitoring is conducted to establish baseline data.

\section{Detection Monitoring}

Detection monitoring is being performed at three units: (1) the X-735 landfill (RCRA and industrial solid waste portions), (2) the X-701C neutralization pit, and (3) the X-749A classified materials disposal facility.

\section{X-735 Landfill}

The X-735 landfill is located on the northern part of DOE/PORTS (see Figure 6.5). Initially, a total of 17.9 acres were approved for landfill use by the Ohio EPA and the Pike County Department of Health for the disposal of sanitary solid waste. An investigation conducted by DOE/PORTS indicated that wipe rags contaminated with solvents had inadvertently been disposed in cells one through six of the landfill. The Ohio EPA determined that these cells be closed as a RCRA hazardous waste landfill. The remaining three cells are regulated by solid waste regulations. Construction of a RCRA cap for the northern portion of X-735 began in 1994 and was completed in July 1995. The unit was certified closed in 1995.

The cells containing hazardous waste occupy the northern part of the landfill, and the cells that contain only industrial solid waste occupy the southern part. There is an undisturbed buffer between the two sections.

\section{Groundwater Investigations}

Until the second half of 1995 , when closure was completed, seven wells were used for detection monitoring for both portions of the landfill. These wells surround the perimeter of the entire landfill, including both the RCRA and the industrial solid waste portions. As part of the landfill closure project, six additional wells were installed in 1994 around the northern (RCRA) portion of the landfill. These six wells, along with all of the original seven wells, have been selected for detection monitoring of the northern and southern portion of the landfill. Samples were analyzed for the chemical parameters listed in Table 6.2. Detection monitoring of the RCRA portion will be conducted quarterly for the first year (beginning with the fourth quarter of 1995), then semiannually in subsequent years. Currently, four of the original seven wells, which bound the southern half of the landfill, are still used for semiannual detection monitoring of the industrial solid waste portion of the X-735 landfill. 


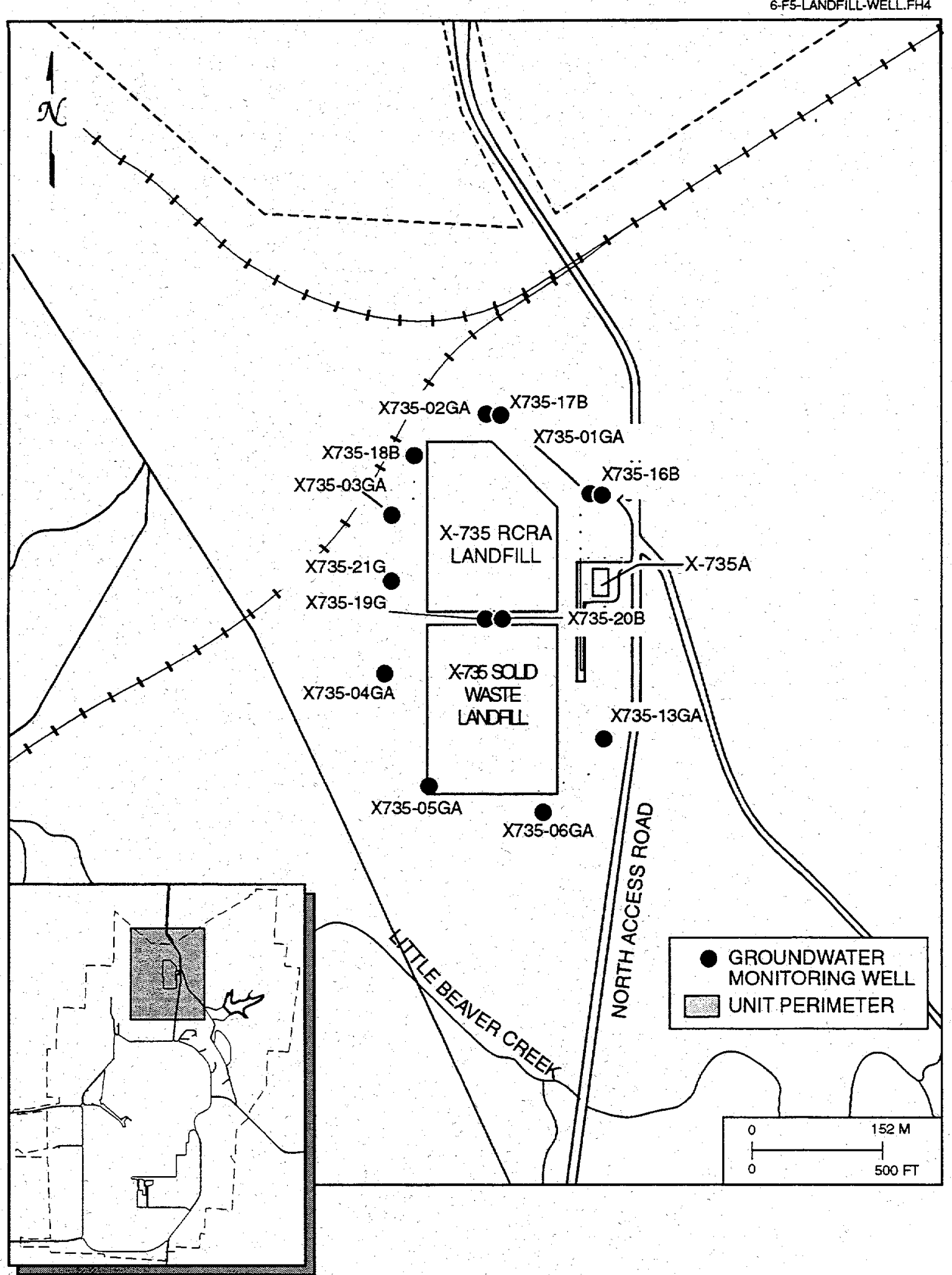

Fig. 6.5. X-735 landfill monitoring well locations. 


\section{Groundwater Flow}

The calculated hydraulic conductivity $(K)$ in the Gallia sand ranges from a high of 1,440 ftday to a low of $4.3 \mathrm{ft} /$ day. The arithmetic mean hydraulic conductivity value of $430 \mathrm{ft} /$ day is used in determining groundwater flow velocity for the Gallia sand. The calculated groundwater flow rates range from 1.7 to $3.4 \mathrm{ft} /$ day.

\section{Extent of Contamination}

Statistical analysis of the indicator parameters indicates that no contamination exists downgradient of the X-735 landfill. No volatile organic compounds (VOCs) have been detected. The VOC carbon disulfide $\left(\mathrm{CS}_{2}\right)$ has occasionally been detected, but it is believed to be the result of sampling- or laboratory-induced contamination.

\section{X-701C Neutralization Pit}

The X-701C neutralization pit unit consists of a neutralization pit and a pump pit. The dimensions of the neutralization pit are $25 \mathrm{ft}$ by $25 \mathrm{ft}$, with a depth of $18 \mathrm{ft}$. The floors and walls are constructed of concrete and lined with acid-proof brick. A sump in the bottom of the neutralization pit drains into the adjacent pump pit. The pump pit, which is constructed of concrete, has an area of about $81 \mathrm{ft}^{2}$ and is $9 \mathrm{ft}$ deep. Two feeder lines enter the $X-701 \mathrm{C}$ pit: an 8 -in. line from the $X-700$ chemical cleaning facility and a 4 -in. line from the $X$ $701 \mathrm{~A}$ lime house.

The X-701C neutralization pit has not been used since 1989. All lines leading into and out of the pit have been capped or rendered unusable. The only material that currently collects in the pit is precipitation through the pit's open top and groundwater that infiltrates the pit's sidewalls.

\section{Groundwater Investigations}

The vicinity of the X-701C neutralization pit was included in the seven-unit investigative area of the Quadrant II RFI conducted in 1991 and 1994. During 1995 groundwater detection monitoring, initiated in 1993 for this unit at three well locations (X701-68G, X701-69G, and X701-70G), continued on a semiannual basis. In August 1995, Ohio EPA instructed DOE to conduct an investigation designed to determine whether the $\mathrm{X}-701 \mathrm{C}$ neutralization pit is a continuing source of contamination to the surrounding groundwater. This investigation is scheduled to be conducted in 1996. If it is determined that the pit contributes to the contamination of the groundwater, the pit will be demolished and removed from the site.

\section{Groundwater Flow}

Groundwater flow in the vicinity of the X-701C neutralization pit is to the west toward the $X-700$ building (see Figure 6.6). Groundwater flow in this direction is caused by the pumping of sumps in the $X-700$ and $\mathrm{X}-705$ buildings, which has also caused a cone of depression centered under these buildings. This is a local reversal of groundwater flow direction. Without the pumping of these sumps, groundwater flow would 
6-FG-701CPITFFH

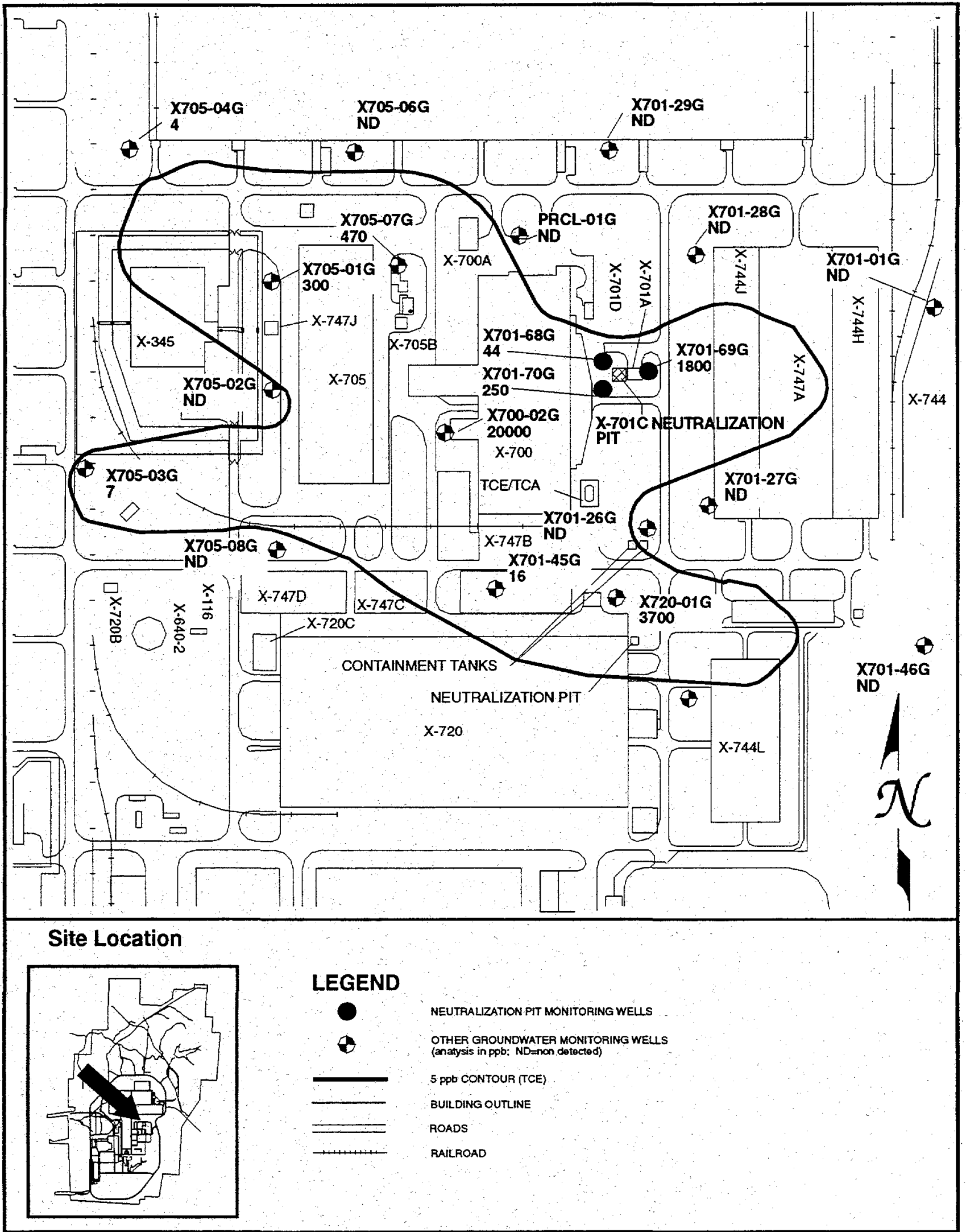

Fig 6.6. X-70tC neutralization pit monitoring well locations, 1995. 
be to the east toward Little Beaver Creek. With the induced groundwater flow direction, the upgradient well is X701-69G and downgradient wells are X701-68G and X701-70G.

The hydraulic conductivity of the Gallia sand in the vicinity of the X-701C neutralization pit is about $37 \mathrm{ft} /$ day. Calculated groundwater flow velocities range from 2.0 to $2.4 \mathrm{ft} /$ day.

\section{Extent of Contamination}

Results of the Quadrant II RFI indicate that the X-701C neutralization pit is located within a TCE groundwater plume centered under the X-700 chemical cleaning facility and the X-705 decontamination building. This plume is being investigated under the RCRA Corrective Action Program. The concentration of TCE in the groundwater surrounding the X-701C neutralization pit is shown in Figure 6.6.

\section{X-749A Classified Materials Disposal Facility}

The X-749A facility, a six-acre area located east of the X-231B southwest oil biodegradation plot, operated from 1953 through 1988. It was a disposal site for wastes classified under the Atomic Energy Act. Potential contaminants include PCBs, asbestos, radionuclides, and industrial trash. This unit underwent closure beginning in 1993. The first phase of the closure was the installation of a drainage system to collect surface water runoff. The drainage system effluent discharges via a USEC NPDES-permitted outfall. The second phase of the closure, construction of a multilayer cap, was completed in 1994.

\section{Groundwater Investigations}

The vicinity of X-749A was included in the "five unit" investigative area of the Quadrant I RFI conducted in 1991 and 1994. For the RFI, groundwater samples from nine wells were collected and analyzed. As of 1995, 12 monitoring wells have been installed at X-749A. The locations of these wells are shown in Figure 6.7. Eleven of these wells were sampled quarterly during the first half of 1995, and once during the second half, in accordance with the approved closure plan for X-749A. Sampling results indicate that X-749A is not a source for the "five unit" investigative area groundwater plume.

\section{Groundwater Flow}

In general, all of the DOE/PORTS monitoring wells, with the exception of a few bedrock wells, are completed in the Gallia sand, just above bedrock, with depths averaging 35 feet. The Gallia sand in the area of $\mathrm{X}-749 \mathrm{~A}$ is comprised of sand, rounded gravel, and weathered shale fragments. This coarse material ranges in thickness from zero to five feet, and in general, thins toward Big Run Creek. Below the sand and gravel deposit lies the dark gray to black Sunbury shale, whose thickness beneath X-749A is approximately $10 \mathrm{ft}$.

Groundwater at the site generally flows to the southeast, toward Big Run Creek where it may discharge. A quadrant-wide groundwater model constructed for the RFI yielded a calibrated hydraulic conductivity for the Minford and Gallia sand in the vicinity of X-749A of $0.73 \mathrm{ft} /$ day and $34 \mathrm{ft} /$ day, respectively. 


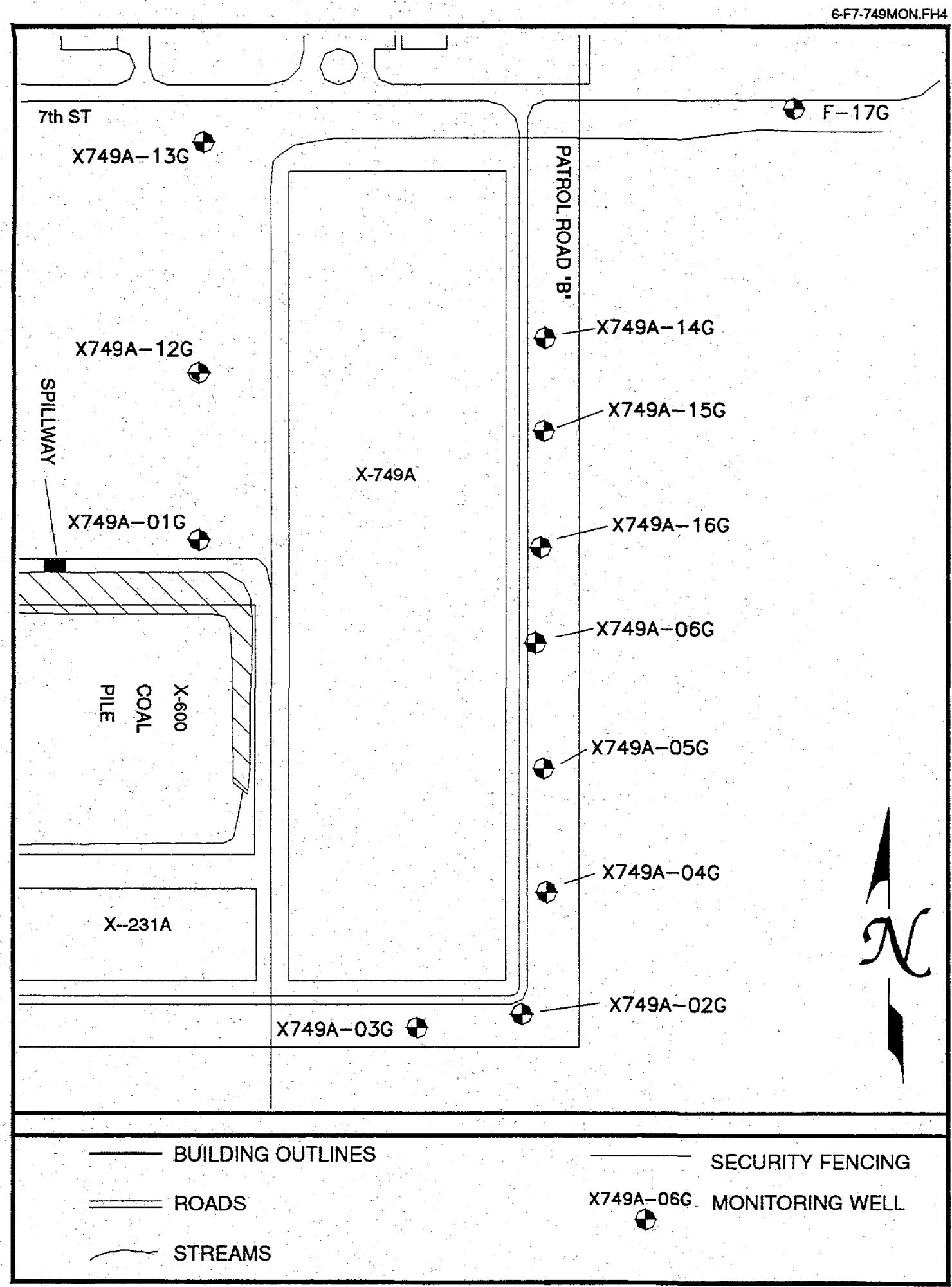

Fig. 6.7. X-749A monitoring well locations. 


\section{Extent of Contamination}

Statistical analysis of the indicator parameters for this site (technetium, uranium, total dissolved solids, specific conductance, $\mathrm{pH}$, and total organic carbon) indicates that no contamination exists downgradient of the X-749A disposal facility. No VOCs have been detected. Comparison of results from downgradient and upgradient wells indicates that no inorganics, metals, or radionuclides are leaching from $X$ 749A. However, contaminated groundwater (Quadrant I investigation area) is present west of X-749A. The mapped eastern edge of the contaminated groundwater is within $100 \mathrm{ft}$ of the western edge of X-749A.

\section{Assessment Monitoring}

Assessment monitoring is being performed on four RCRA units: (1) the X-701B holding pond, (2) the X-231B southwest oil biodegradation plot, (3) X-616 chromium sludge surface impoundments, and (4) X749 contaminated materials disposal facility. The contaminants are mainly VOCs [1,1,1-trichloroethane (TCA) and TCE] and low-energy beta emitters $\left({ }^{99} \mathrm{Tc}\right)$.

GWQAs for all four units were performed from 1988 to 1989. The GWQAs characterized the extent, rate of migration, and concentration of hazardous waste and hazardous waste constituents released from each unit. The investigation results indicated that several factors controlled groundwater flow and contaminant migration at the units: the thickness and hydraulic conductivity of the Gallia sand and Minford silt, the thickness and low vertical conductivity of the Sunbury shale, the presence of storm drains, and the low hydraulic conductivity of the Minford clay.

Groundwater assessment networks for these units are designed to evaluate contaminant concentrations and movement of indicator parameters. The networks consist of monitoring wells with well screens located in either the Gallia sand or Berea sandstone. Monitoring wells screened in the Gallia sand were installed in the centers of plumes, at the edges of plumes, and downgradient of plumes. Monitoring wells screened in the Berea sandstone were installed downgradient of plumes. Results obtained from chemical analyses of samples from these wells (1) indicate maximum concentrations of contaminants, (2) detect contaminants or quantify changes over time of the concentration of contaminants at the edges of plumes, (3) detect lateral migration of contaminants in the Gallia sand, and (4) detect downward migration of contaminants through the Sunbury shale and into the Berea sandstone.

Surface water monitoring is conducted in conjunction with groundwater monitoring to determine if the contaminated groundwater has reached surface water. Surface water monitoring sites and their associated discharge points (see Figure 6.8) are:

- Little Beaver Creek and East Drainage Ditch sample locations (LBC-SW01 to LBC-SW04 and EDDSW01), which assess X-701B and X-230J7 groundwater discharges.

- The unnamed drainage ditch at the southwest corner of Portsmouth (UND-SW01 and UND-SWO2) and Big Run Creek (BRC-SW01 and BRC-SW02) sample locations, which assess the X-749 groundwater discharges. Big Run Creek sample locations also provide assessment for the X-231B southwest oil biodegradation plot.

- West Drainage Ditch sample locations (WDD-SW01 to WDD-SW03), which assess X-616 groundwater discharges.

- The North Holding Pond sample location (NHP-SW01) which assesses additional groundwater discharges. 
6-F8-SURFACE-MON.FH4

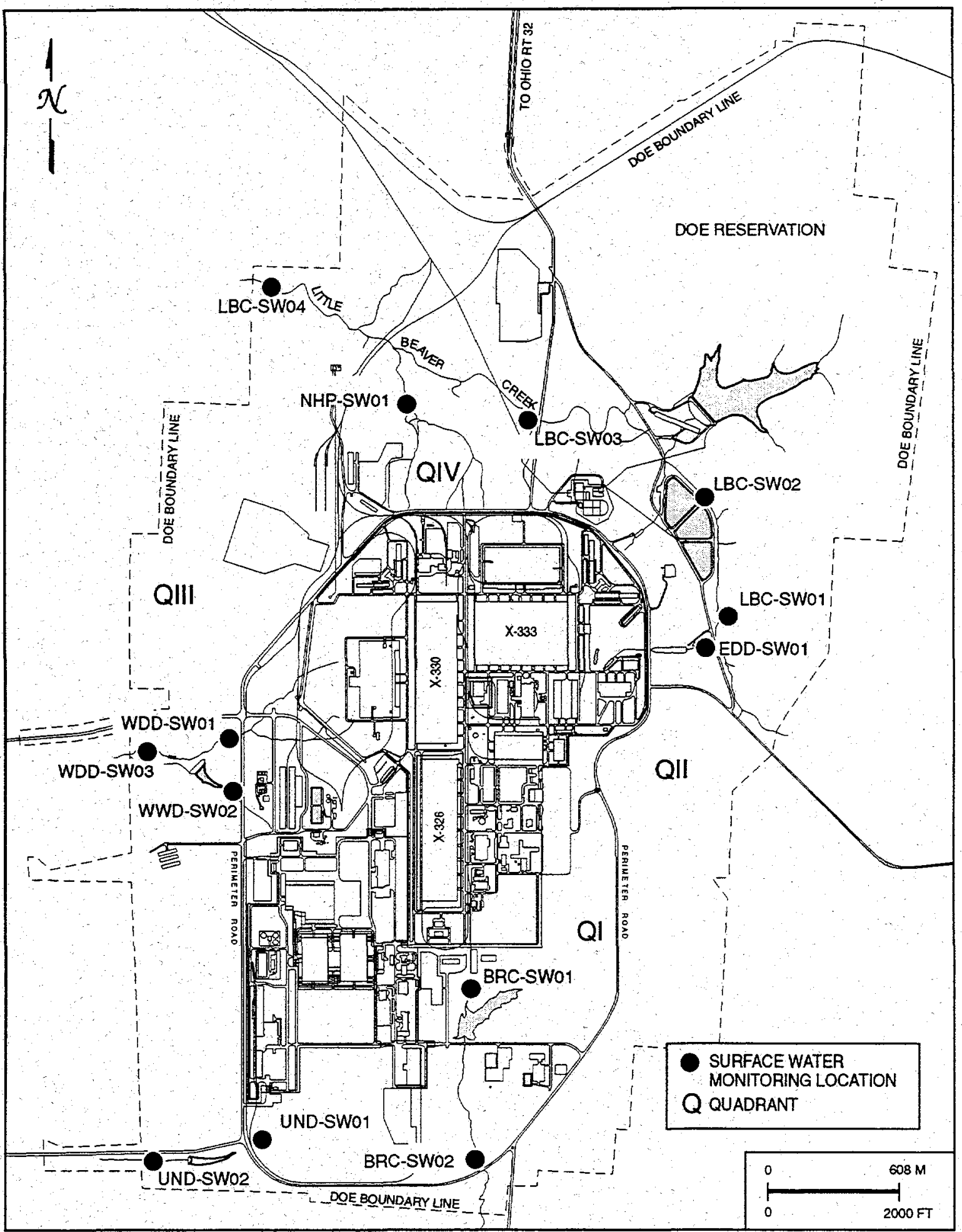

Fig. 6.8. Surface water monitoring locations. 


\section{X-701B Holding Pond}

The X-701B holding pond (see Figure 6.9) is a group of unlined ponds consisting of a holding pond and the east and west retention basins. The holding pond was used from the beginning of plant operation in 1954 until November 1988. The pond was designed for neutralization and settlement of acid waste from several sources, including the X-701C neutralization pit (which receives waste from the X-700 chemical cleaning building), the $X-705$ decontamination building, and the $X-720$ maintenance building. While most wastes discharged to the X-701B holding pond were acid wastes, degreasing solvents, including TCA and TCE, were also discharged to the pond.

Beginning in 1974 slaked lime was added to the waste streams to neutralize the acid and to induce precipitation of radionuclides. The accumulated sludge was dredged annually and placed in the east retention basin from 1974 to 1980 . After 1980 the sludge was placed in the west retention basin. Like the holding pond, these retention basins were unlined and did not have a leachate collection system.

\section{Groundwater Investigations}

Several groundwater investigations have occurred at this unit as well as installation of 74 groundwater monitoring wells: eight wells are screened in the Minford clay/silt, 57 in the Gallia sand, one in the Sunbury shale, and 8 in the Berea sandstone. Twenty-seven wells have been selected for quarterly assessment sampling. The samples are analyzed for parameters given in Table 6.2.

In 1995 a three-dimensional multiphase groundwater flow model was initiated to predict the volume and extent of dense nonaqueous phase liquids (DNAPLs) containing TCE in the subsurface. Preliminary results of the modeling efforts correlated well with the observed data. Additional model refinement is planned to be done in 1996. Final results will be used to evaluate potential remediation alternatives.

\section{Groundwater Flow}

The primary pattern of groundwater movement in the Minford clay/silt is vertically downward. Approximately $80 \%$ of the water entering the Minford clay/silt moves downward to the Gallia sand.

The primary pattern of groundwater movement in the Gallia sand is horizontal. Groundwater in the Gallia sand near X-701B holding pond flows radially from a groundwater mound located about $1,200 \mathrm{ft}$ north of the holding pond. Groundwater flows from the mound southward under the $\mathrm{X}-701 \mathrm{~B}$ holding pond and then turns eastward toward Little Beaver Creek. A groundwater divide is located just west of the holding pond, indicating that all groundwater in the X-701B holding pond area discharges either to Little Beaver Creek, the X-230J7 east holding pond, or the East Drainage Ditch (see Figure 6.9).

Calculated groundwater flow velocity ranges from 0.8 to $1.6 \mathrm{ft} /$ day. The hydraulic conductivity of the Gallia sand is higher near the X-701B holding pond and decreases toward Little Beaver Creek. The hydraulic gradient is lowest near the X-701B holding pond but increases in the same direction that the hydraulic conductivity decreases so that the groundwater velocity remains nearly constant.

Practically all inflow to the Sunbury shale migrates vertically downward to the Berea sandstone, although this is only $2.4 \%$ of the water that enters the Gallia sand. Groundwater flow velocities calculated for the Sunbury shale are much lower than those for the Gallia sand or Berea sandstone. This is consistent with field observation of thick, competent shale in the vicinity of the X-701B holding pond.

The groundwater flow direction in the Berea sandstone, toward Little Beaver Creek, is the same as it is for the other geologic units in the vicinity of the X-701B holding pond. However, groundwater in the Berea 
6-F9-701.FH4

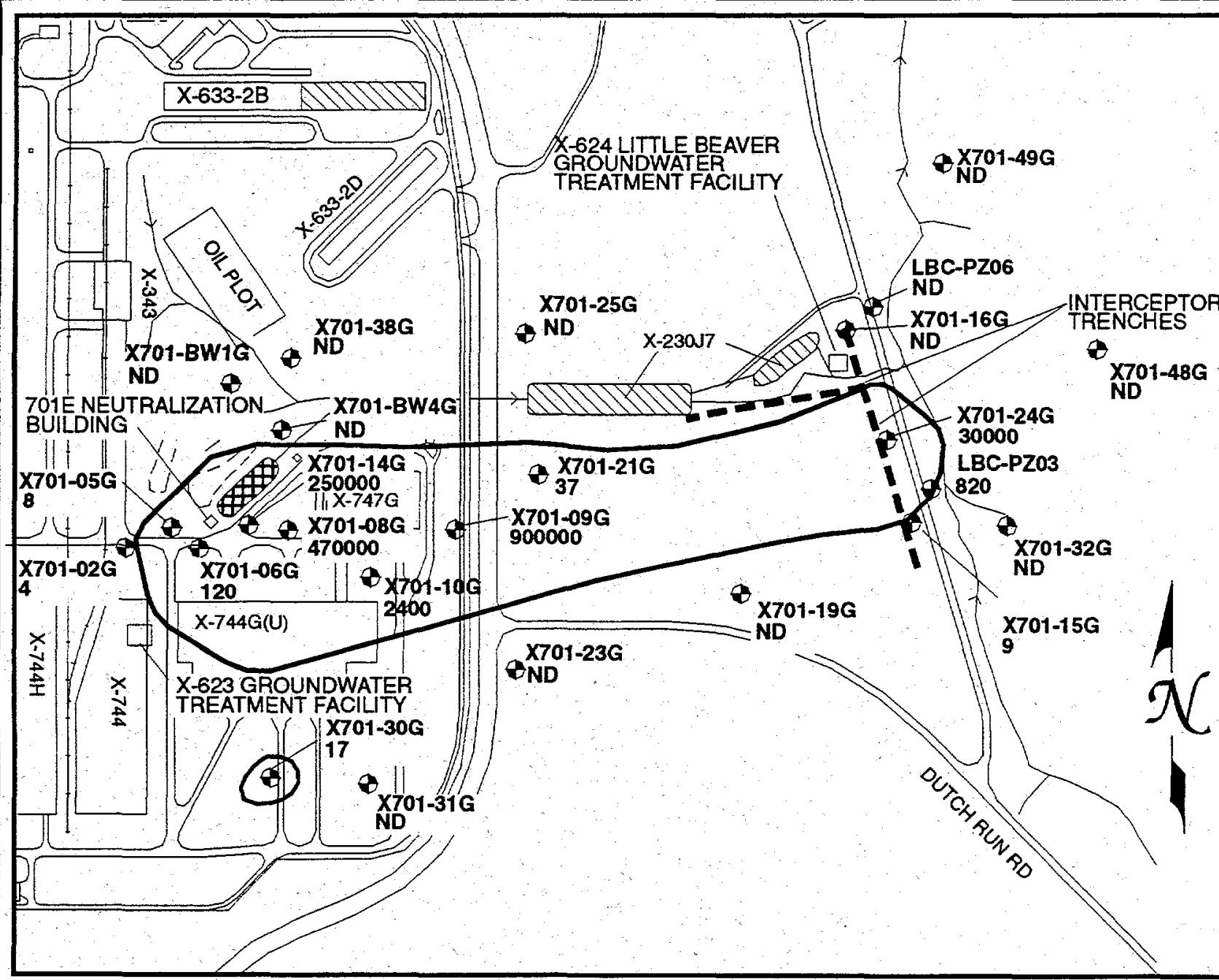

Site Location

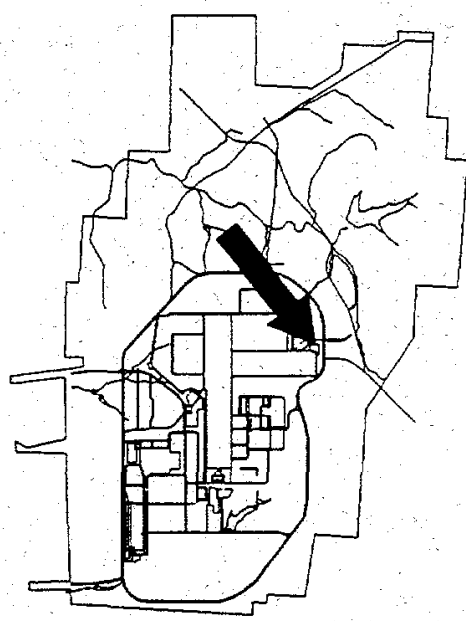

\section{LEGEND} $\begin{array}{ll}\text { GROUNDWATER MONITORING WELL } \\ \text { X701-23G } & \text { (anatysis in Ppt: NO=non detected) }\end{array}$

ND
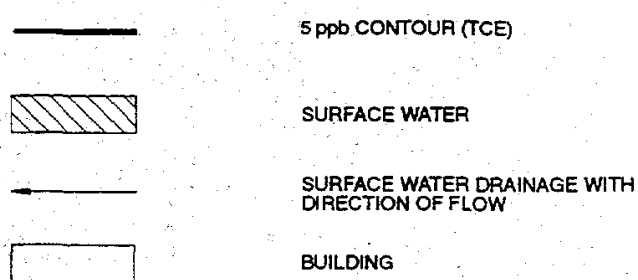

HAI X-701B HOLDING POND

m m INTERCEPTOR TAENCH

Fig 6.9. X-701B holding pond - extent of TCE concentration, 1995. 
sandstone does not discharge to Little Beaver Creek because the Sunbury shale is an upper confining bed for the Berea sandstone and the Berea sandstone is not exposed at the creek.

\section{Extent of Contamination}

Groundwater contamination in the Gallia sand is characterized by a long, narrow plume of mixed organic and radioactive constituents; the plume extends from the X-701B holding pond to Little Beaver Creek (Figure 6.9).

TCE has migrated farther than any other contaminant and defines the extent of contamination. Contaminant plumes for other constituents have a pattern similar to that for TCE. Other VOCs of concern at the X-701B holding pond include 1,1,1-TCA and 1,1-dichloroethene (DCE). The following is a summary of contaminant plume information:

- Contaminant migration is to the east (toward Little Beaver Creek), corresponding to the location of thick but narrow deposits of Gallia sand.

- Groundwater flow converges from both the north and south, forcing a narrowing of flow.

- Contamination has been detected in samples from Little Beaver Creek and the East Drainage Ditch.

- No contamination has been detected east of Little Beaver Creek.

- Small amounts of TCE have been detected in the Berea sandstone.

Qualitative evaluations of benthic fauna, conducted in 1991 and 1992, indicated that species of pollution-sensitive macroinvertebrates (e.g., Ephemeroptera, Trichoptera, and Plecoptera) were absent and that pollution-tolerant taxa (e.g., Diptera and Chironomidae) were abundant. Subsequent surface water sampling in the East Drainage Ditch revealed that the TCE plume from the X-701B holding pond was discharging into the East Drainage Ditch below the X-230J7 east monitoring facility holding pond embankment. As a result, further analysis of the groundwater flow regimes was conducted and an improved groundwater flow model was developed.

\section{Remediation Measures}

A T-shaped Interceptor trench (french drain) with extraction wells has been installed near Little Beaver Creek and the East Drainage Ditch to capture contaminated groundwater. The primary interceptor trench is situated parallel to the west bank of Little Beaver Creek and intercepts the TCE plume that could possibly enter Little Beaver Creek. The secondary interceptor trench is situated parallel to the south bank of the East Drainage Ditch and intercepts the TCE plume that could possibly enter the East Drainage Ditch. The interceptor trench location and the extent of the TCE contamination plume are shown in Figure 6.9. The lower part of the interceptor trench is backfilled with gravel to facilitate flow, while the upper part is backfilled with clean soil. The primary trench is $660 \mathrm{ft}$ long and has two extraction wells completed in the backfill; the secondary trench is $440 \mathrm{ft}$ long and intersects the primary trench.

\section{X-231B Southwest Oil Biodegradation Plot}

The X-231B southwest oil biodegradation plot was used from 1976 to 1983 for land application of waste oils and degreasing solvents and consists of two disposal plots, each surrounded by an elevated soil 
6-F10-231.FHA

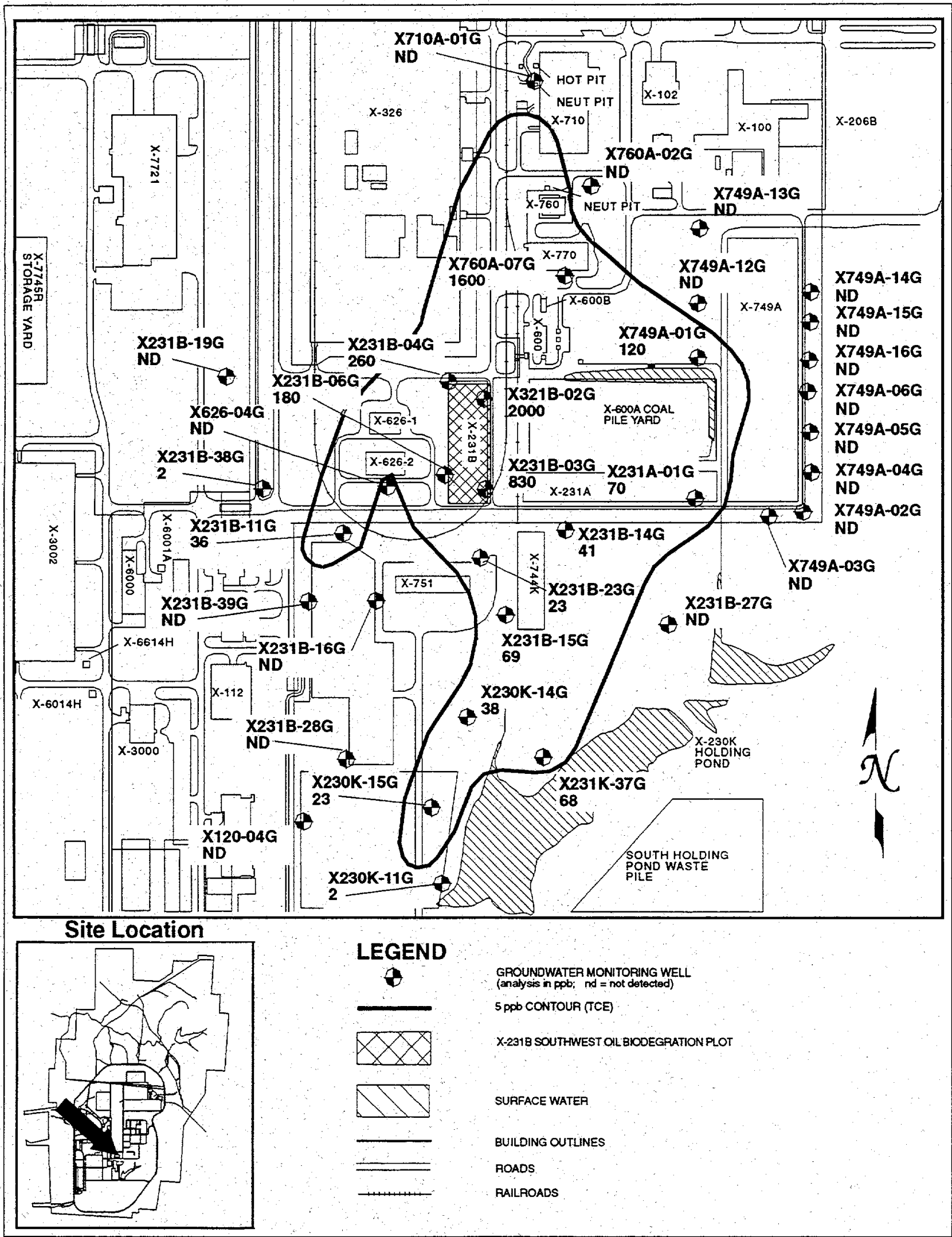

Fig. 6.10. X-231B southwest oil biodegradation plot monitoring well locations and TCE contaminant plume, 1995. 
berm. The plots were periodically fertilized and disced to enhance aeration and promote natural biological degradation of waste oil. Since ceasing operation in 1983, these plots have been remediated to remove the VOC contamination present in the soil. Assessment monitoring will continue until the unit requires no further action.

\section{Groundwater Investigations}

Since 1985 several groundwater investigations and installations of monitoring wells have occurred. At the completion of the GWQA investigation, 35 monitoring wells were installed in the vicinity of this unit (see Figure 6.10): three wells were screened in the Minford clay/silt, 25 in the Gallia sand, one in the Sunbury shale, and six in the Berea sandstone. Fifteen wells have been selected for quarterly assessment monitoring. Samples are analyzed for the chemical parameters listed in Table 6.2.

\section{Groundwater Flow}

The primary pattern of groundwater movement in the Minford clay/silt is vertically downward to the Gallia sand. Groundwater entering the Gallia sand at the X-231B southwest oil biodegradation plot flows laterally, primarily to the southeast toward the $\mathrm{X}-230 \mathrm{~K}$ south holding pond. Most groundwater remains in the Gallia sand and does not migrate downward into the Berea sandstone. The horizontal hydraulic gradient is very low because the $\mathrm{X}-231 \mathrm{~B}$ southwest oil biodegradation plot is located in an area where the bedrock is relatively flat; thick, permeable Gallia sand deposits are present; and the area is close to the east-west groundwater divide that runs through the Portsmouth site. The vertical hydraulic gradient from the Gallia sand to the Berea sandstone is steep and has an average potentiometric difference of 8 to $10 \mathrm{ft}$; approximately $1 \%$ of the water entering the Gallia sand migrates to the Berea sandstone.

The hydraulic conductivity of the Gallia sand is $41.0 \mathrm{ft} /$ day, and the average flow velocity is $1.2 \mathrm{ft}$ day. The Gallia sand is thin, generally less than $1.2 \mathrm{ft}$ thick, below the $\mathrm{X}-231 \mathrm{~B}$ southwest oil biodegradation plot: More extensive Gallia sand deposits occur to the southeast and east of the unit. The average groundwater velocity for the Gallia sand is approximately $2.0 \mathrm{ft}$ day.

The hydraulic conductivity of the Sunbury shale is significantly lower than the hydraulic conductivity of the Gallia sand. Therefore, the downward vertical migration of groundwater from the Gallia sand to the Berea sandstone is impeded.

Groundwater in the Berea sandstone flows to the southeast. The flow system is not similar to that in the Gallia sand because of the presence of relatively thick ( $8 \mathrm{ft}$ or more) Sunbury shale. Surface drainage influences the direction of groundwater flow in the Gallia sand but not in the Berea sandstone. The calculated average linear groundwater velocity for the Berea sandstone is $0.1 \mathrm{ft} / \mathrm{day}$.

Groundwater flow modeling predicts that groundwater movement from the $\mathrm{X}-231 \mathrm{~B}$ southwest oil biodegradation plot is slow and may eventually discharge to the $\mathrm{X}-230 \mathrm{~K}$ south holding pond (Figure 6.10 ).

\section{Extent of Contamination}

The VOC plumes at the X-231B southwest oil biodegradation plot are smaller in extent than those at the X-701B holding pond. The plumes are narrow and elongated in the north-south direction. The Gallia sand contamination plume at the X-231B southwest oil biodegradation plot extends about $1,000 \mathrm{ft}$ to the south toward the X-230K holding pond. The northern boundary of the TCE plume is near the south end of the 
X-710 building. The areal extent of the TCE plume encompasses the areal extent of all other VOC plumes associated with the X-231B oil biodegradation plot, and the levels of TCE are also higher than any other VOC.

\section{Remediation Measures}

As part of closure on this unit, three groundwater extraction wells were installed in the Gallia sand. These wells are located south of the unit and are aligned across the central portion of the TCE contaminant plume (shown in Figure 6.10). The extracted groundwater is treated by activated carbon filters at the X-622 south groundwater treatment facility.

In 1994 the $\mathrm{X}$-231B vadose zone was remediated using in situ thermal enhanced vapor extraction to remove VOCs. The process utilized an 8-ft diameter auger to mix the vadose soils. During the soil mixing, heated air was injected into the soils. The off-gas was collected in a 12-ft diameter shroud and transferred to a carbon adsorption filter. A vacuum was imparted on the shroud to collect and transfer the off-gases. Approximately $80 \%$ of the VOCs present in the vadose zone were removed by this treatment. An interim cap has been installed over the unit until final closure is accomplished. Assessment monitoring will continue at the X-231B southwest oil biodegradation plot until final closure and the initiation of post-closure monitoring.

\section{X-616 Chromium Sludge Surface Impoundments}

The X-616 chromium sludge surface impoundments consist of two unlined lagoons that were used from 1976 to 1985 for storage of sludge generated by treatment of recirculating cooling water blowdown from the DOE/PORTS process cooling system. A hexavalent chromium-based corrosion inhibitor was used in the cooling water system. The chromium in the blowdown was reduced to a trivalent chromium at the X-616 impoundments by adding sulfur dioxide to the water, which produced sulfurous acid $\left(\mathrm{H}_{2} \mathrm{SO}_{3}\right)$. The resulting chromium hydroxide sludge was then precipitated in a clarifier by $\mathrm{pH}$ adjustment with slaked lime and a polymer coagulant. The sludge was pumped to the X-616 impoundments, where it was stored.

From February to May 1987, treated process effluent from the X-700 chemical cleaning facility, via the X-701C neutralization pit, was diverted to the X-616 surface impoundments to reduce the high concentration of suspended solids discharged from the X-701B holding pond. In addition, chlorinated organic solvents were discovered in the X-700 chemical cleaning facility basement sump that discharges to the X-701C neutralization pit.

This unit was certified closed in 1993, and semiannual post-closure monitoring has been conducted since 1994. Closure activities at the X-616 impoundments included dewatering, removing the chromium sludge, and backfilling the ponds with clean fill.

\section{Groundwater Investigations}

Since 1978 groundwater investigations have been conducted, and monitoring wells have been installed at the X-616 chromium sludge surface impoundments. During the GWQA study for the X-616 impoundments, 22 groundwater monitoring wells were sampled. Some VOCs were found in isolated wells at concentrations below $10 \mathrm{ppb}$. In November 1989, four wells were sampled for RCRA Appendix IX analytes 
and elevated levels of total chromium were detected. In 1990 quarterly sampling for chromium was conducted at 12 wells. The results indicated that some total chromium results exceeded regulatory limits. Upon completion of the GWQA, 28 monitoring wells were installed in the vicinity: three in the Minford clay/silt, 20 in the Gallia sand, and five in the Berea sandstone (Figure 6.11).

During this time, the X-616 chromium sludge surface impoundments were undergoing a clean closure according to RCRA requirements. A review of all groundwater data showed that TCE had been detected at low levels (less than $30 \mathrm{ppb}$ ) in monitoring wells not included in the 12-well monitoring network; therefore, a clean closure could not be certified. Two wells at which TCE had been detected were added to the monitoring well network. When TCE was detected in these two wells, an adjacent well was added to the monitoring well network.

During the 1995 post-closure monitoring program, 15 wells were monitored. Samples were analyzed for the chemical parameters listed in Table 6.2.

\section{Groundwater Flow}

At the X-616 chromium sludge surface impoundments, the Gallia sand is 4 to $6 \mathrm{ft}$ thick, and it thins in all directions away from the surface impoundments. The Sunbury shale is absent under the X-616 surface impoundments, so the Gallia sand overlies the Berea sandstone. Hydraulic conductivity in the Gallia sand is about $3.5 \mathrm{ft} /$ day, and groundwater velocity ranges from 0.02 to $0.04 \mathrm{ft} /$ day. Before closure, groundwater flow, from the site was reported as being radial. Since closure, groundwater flow in the Gallia sand has changed to a predominantly west-northwest direction toward local drainage channels of the west drainage ditch.

Groundwater flow in the Berea sandstone is primarily to the northwest. Groundwater in both the Gallia sand and the Berea sandstone flows away from the X-616 impoundments through two forks of the west drainage ditch to the $X-230 J 5$ holding pond. The average Berea sandstone hydraulic conductivity in the vicinity of the $X-616$ surface impoundments is $0.35 \mathrm{ft} /$ day, which is higher than that measured at the other assessment monitoring units. Because the Sunbury Shale is absent, the Gallia and Berea are in direct hydrologic communication. Groundwater flow modeling predicts that groundwater from both the Gallia sand and the Berea Sandstone discharges to the West Drainage Ditch, with an estimated groundwater travel time in excess of 30 years for both.

\section{Extent of Contamination}

MCLs and action levels were established for X-616. The only significant VOC measurement in 1995 was TCE, which exceeded the MCL in only one well; however, this result is a decrease from 1994. Metals were monitored for levels in excess of their MCLs. The most significant metal measurement in 1995 was dissolved chromium, which exceeded the MCL in only one well (Figure 6.11); however, this result is also a decrease from 1994. The overall results of post-closure monitoring at X-616, indicate that since closure, contamination has decreased at locations exceeding the $\mathrm{MCL}$, while contamination remains well below the $\mathrm{MCL}$ at all other locations.

\section{X-749 Contaminated Materials Disposal Facility}

Operation of the X-749 contaminated materials disposal facility began in the 1950 s. No detailed records of wastes deposited in the yard were kept until after 1976. Records kept from 1976 to 1990 indicate 


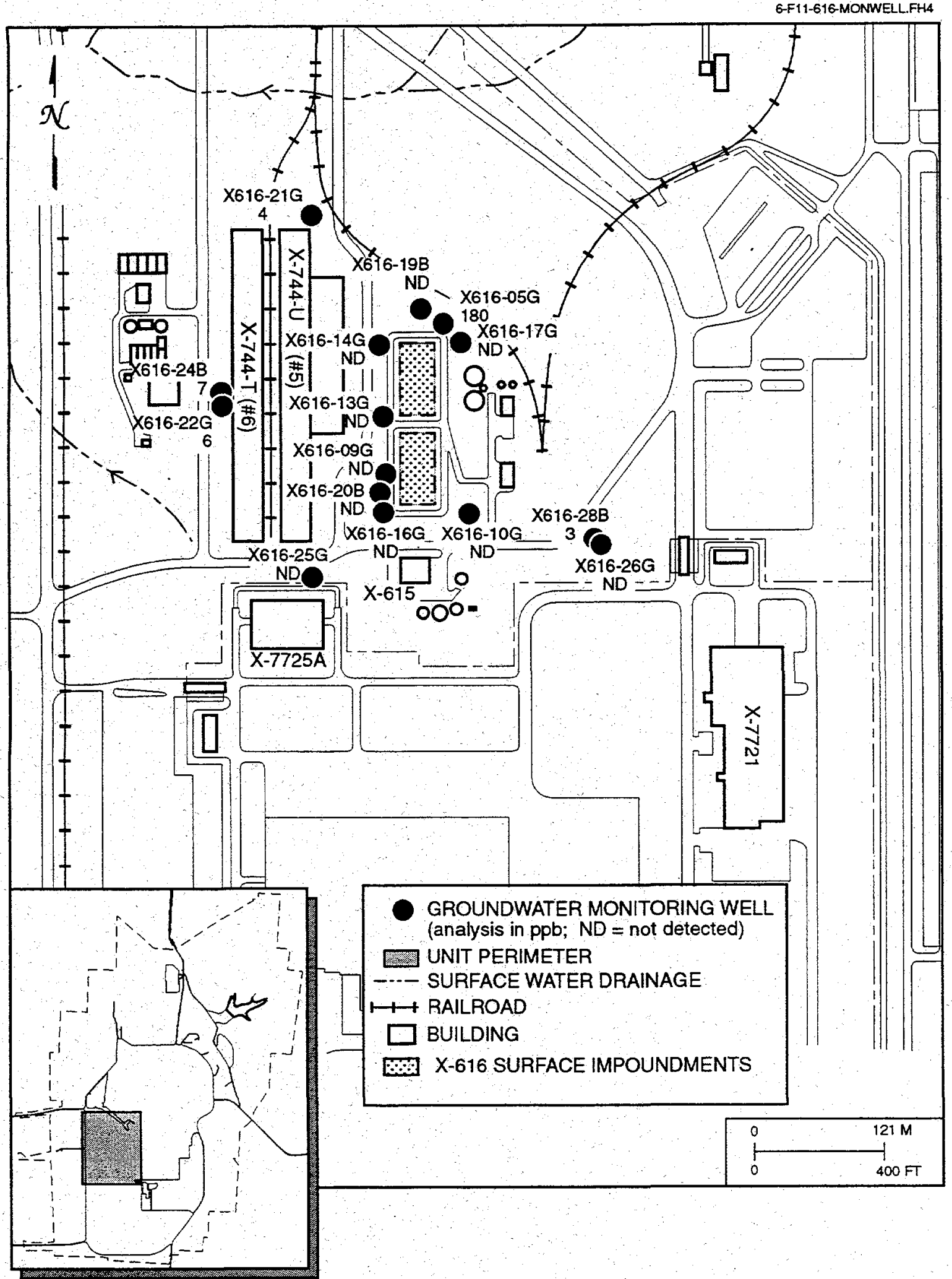

Fig. 6.11. X-616 groundwater monitoring well locations - extent of dissolved chromium contamination, 1995. 
that deposited wastes consisted of $85 \%$ scrap materials and $15 \%$ containerized solids. Typically, wastes were placed in trenches approximately 12 to $15 \mathrm{ft}$ deep and were then covered with earth. The X-749 contaminated materials disposal facility was closed in 1992 in accordance with RCRA requirements. Elements of the closure included

- installation of a multimedia cap,

- installation of a slurry wall along the north side and northwest corner of the unit,

- installation of subsurface groundwater drains on the northern half of the east side and the southwest corner of the unit, and

- one groundwater extraction well within each of the groundwater drains.

The slurry wall and subsurface drains extend down to bedrock. After collection, groundwater is pumped from the subsurface drains to an activated carbon filtration system at the X-622 south groundwater treatment facility (Figure 6.10), where the groundwater is treated. The decontaminated water is discharged through a USEC-leased NPDES-permitted outfall.

In 1994 an IRM subsurface diversion wall was completed across a portion of the facility's southern boundary (Figure 6.12). The diversion wall, which extends from the surface into the Sunbury Shale, precludes plume migration off plant property prior to the implementation of a final remedial measure.

\section{Groundwater Investigations}

Several groundwater investigations that included installation of groundwater monitoring wells have occurred at this unit. A total of 61 wells have been installed: five wells screened in the Minford clay/silt, 44 in the Gallia sand, one in the Sunbury shale, and 11 in the Berea sandstone (Figure 6.12).

In addition to quarterly assessment monitoring, field investigations were conducted in 1992 and 1993. The work included 75 Geoprobe borings, 21 piezometer or monitoring well installations, two synoptic water level measurements, 27 slug tests, continuous water level recording at three well clusters, groundwater sampling and analysis at 15 wells, digging of 12 test pits, and two pumping tests. This six-month long investigation defined the nature and extent of groundwater contamination and the hydrogeologic characteristics of the shallow water-bearing zone and provided data to support the evaluation and selection process for the closure alternative.

\section{Groundwater Flow}

The primary pattern of groundwater movement in the Minford clay/silt is vertically downward. Approximately $80 \%$ of the surface water entering the Minford clay/silt travels downward to the Gallia sand.

East of the X-749 contaminated materials disposal facility, near Big Run Creek, approximately $76 \%$ of the groundwater entering the Gallia sand flows horizontally, the remainder migrates vertically downward. The vertical component predominantly migrates directly to the Berea sandstone because the Sunbury shale is either thin or absent in this area and has been completely eroded by Big Run Creek.

The direction of horizontal flow is affected by the presence of groundwater-divides. North-south trending groundwater flow-divides are present in both the Gallia sand and the Berea sandstone. The divide in the Gallia sand is situated near the western boundary of the unit: groundwater flowing east from the divide migrates toward Big Run Creek; groundwater flowing to the west migrates toward the unnamed southwest drainage ditch and to the south toward the DOE/PORTS boundary. 


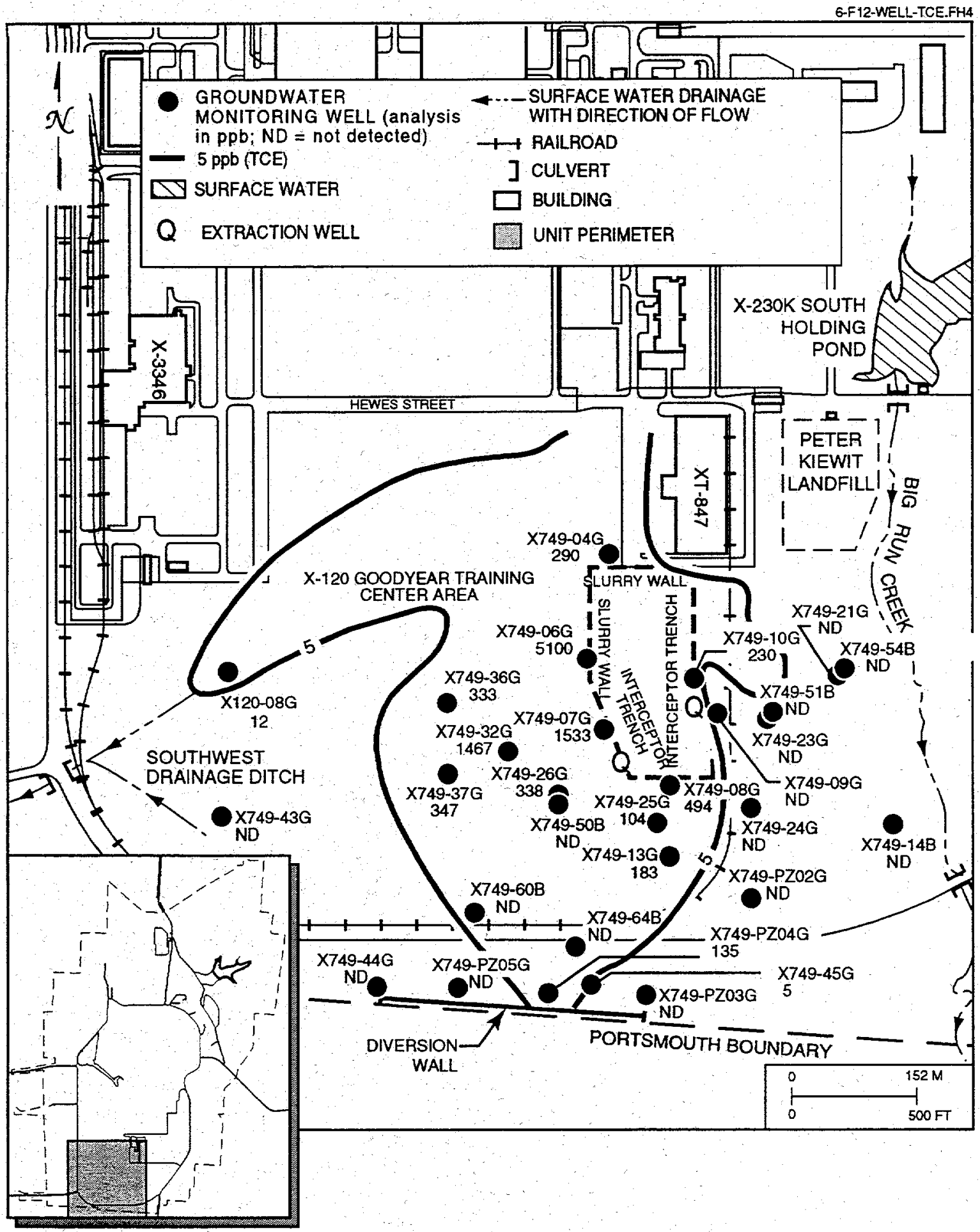

Fig. 6.12. X-749 groundwater monitoring well locations - extent of TCE contamination, 1995. 
Two pumping tests in the Gallia sand were conducted in 1993 at the X-749 contaminated materials disposal facility. Hydraulic conductivity values determined from pumping test data range from 4 to $6 \mathrm{ft} / \mathrm{day}$. Groundwater velocities calculated using these hydraulic conductivity values range from $0.06 \mathrm{ft} /$ day to less than $0.6 \mathrm{ft}$ day. Groundwater flow velocity is relatively constant in the Gallia sand throughout the area of this unit. A decrease in the hydraulic conductivity from the X-749 materials disposal facility toward Big Run Creek is compensated by a rapid drop in elevation over this same distance; this results in higher hydraulic gradients toward the east. Gallia sand potentiometric surface elevations average 8 to $15 \mathrm{ft}$ higher than those of the Berea sandstone. Hydraulic conductivity values for the Sunbury shale, when present, are significantly lower than those for the Gallia sand and Berea sandstone.

The direction of groundwater flow in the Berea sandstone is very similar to that observed for the Gallia sand, except that the north-south trending divide in the Berea sandstone is farther west than the Gallia sand divide. Flow east of the divide migrates toward Big Run Creek; flow west of the divide migrates toward the unnamed southwest drainage ditch. The average groundwater linear velocity in the Berea sandstone is $0.015 \mathrm{ft} / \mathrm{day}$. The area of higher Berea sandstone groundwater velocity is east of the $\mathrm{X}-749$ contaminated materials disposal facility, where the Sunbury shale has been eroded.

\section{Extent of Contamination}

Although 18 wells were originally selected for quarterly assessment sampling, 29 wells were monitored for the first and second quarters of 1995 because of apparent contaminant plume migration. Semiannual post closure monitoring began in the second half of 1995. Samples were analyzed for parameters listed in Table 6.2. The most extensive and most concentrated VOCs at the X-749 contaminated materials disposal facility were TCE and TCA. Other VOCs detected were DCA, DCE, 1,2-DCE, chloroform, and Freon-113. All contaminants were generally lower in concentration than TCE and were contained within the extent of the TCE plume.

The field work in 1992 and 1993 indicated that the TCE plume is closer to the Portsmouth site boundary than was anticipated. The Gallia sand contamination (see Figure 6.12) plume at the X-749 contaminated materials disposal facility extends about $1,500 \mathrm{ft}$ to the south-southwest, about $1,000 \mathrm{ft}$ to the south, and about $200 \mathrm{ft}$ to the southeast of the unit. The largest area of contamination extending to the south corresponds to the area where the Gallia sand deposits are thickest. In 1993 the X-749 IRM investigation was completed and the location of the southern edge of the VOC contamination plume was refined. TCE was detected within $55 \mathrm{ft}$ of the Portsmouth site boundary. A subsurface barrier was selected as the regulator-approved IRM. This subsurface barrier, installed in 1995 , diverts the southern migration of groundwater and contaminant transport.

\section{Groundwater Surveillance Monitoring}

The surveillance monitoring program at DOE/PORTS consists of perimeter exit pathway monitoring, off-site water supply sampling, and baseline monitoring. Perimeter monitoring assesses the effect of the facility on regional groundwater quality and quantity. Off-site sampling and the Portsmouth site water supply well field sampling provide information about any impact of DOE/PORTS operations on the quality of the drinking water supply. Baseline monitoring is conducted to establish baseline data. 


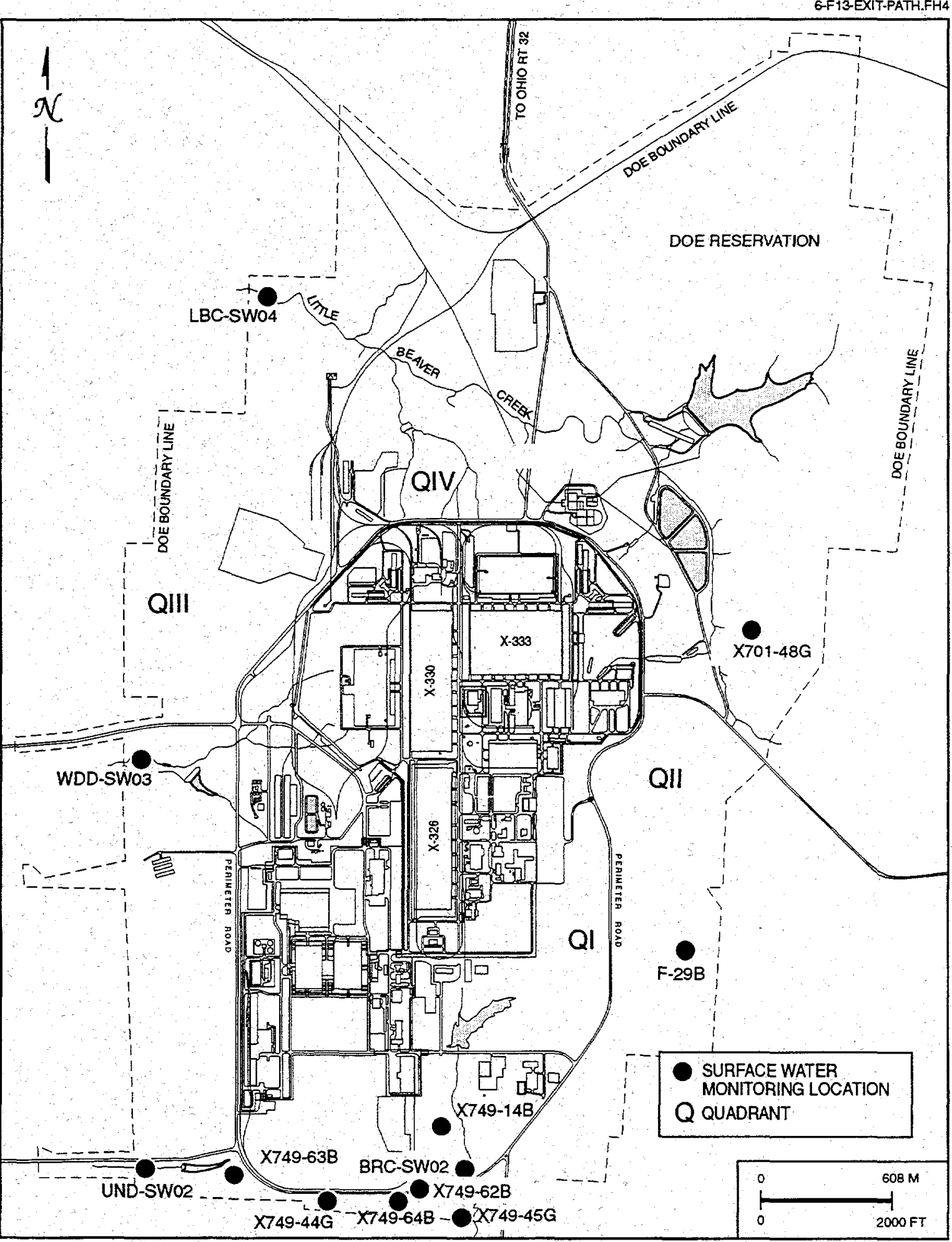

Fig. 6.13. Exit - pathway monitoring locations at DOE/PORTS. 


\section{Perimeter Exit Pathway Monitoring}

Groundwater investigations have determined that the Gallia sand is the primary hydrogeologic unit for contaminant migration at DOE/PORTS. The Gallia sand is not a regionally persistent unit because of the topography on which it was deposited, as well as its depositional environment. Selected locations on local streams and drainage channels near the reservation boundary are sampling points of the surveillance monitoring program because groundwater discharges to these surface waters. Monitoring wells near the reservation boundary are also used in the surveillance monitoring program. Figure 6.13 shows the sampling locations for exit pathway monitoring.

\section{Off-Site Sampling}

The purpose of the off-site sampling program is to ensure that drinking water sources have not been adversely affected by DOE/PORTS operations. Although this program may provide an indication of contaminant transport off-site, it should not be interpreted as an extension of the on-site groundwater monitoring program, which bears the responsibility for detecting contaminants and determining the rate and extent of contaminant movement. Because little is known about how residential wells were constructed and about the pumps used in residential wells, data from this program will not be used in hydrogeologic or geochemical investigations:

Currently, seven residents are participating in the program (see Figure 6.14 for sampling locations and Table 6.2 for the analytical parameters). All sampling for the residential program is conducted semiannually. Sampling locations are added or deleted as residents' requests and program requirements dictate. Typically, sampling locations are deleted when a resident obtains access to the public water supply. Sampling locations are added on request and if there is a probable hydrogeologic connection between DOE/PORTS and a resident's water supply. Residential sampling to date indicates that DOE/PORTS is not affecting residential water supplies.

\section{Baseline Monitoring}

Four well clusters, each composed of one well completed in the Gallia sand and one well completed in the Berea sandstone, are sampled semiannually to determine baseline water quality (Figure 6.15). Sampling is conducted to support the RCRA permit applications and to provide a comparison between on-site wells and off-site background water. In 1995, except for gross alpha and beta concentrations detected above the median background activity levels in one sample from well F-12B, no other contaminants were detected in the baseline monitoring wells.

\section{Peter Kiewit Landfill}

The Peter Kiewit landfill is located west of Big Run Creek just south of the X-230K holding pond (Figure 6.12). The landfill, opened in 1952, was used as the salvage yard, burn pit, and trash area during construction of DOE/PORTS. After the initial construction, the disposal site was operated as a sanitary landfill until 1968, when soil was distributed over the site and graded and the area was seeded with native 


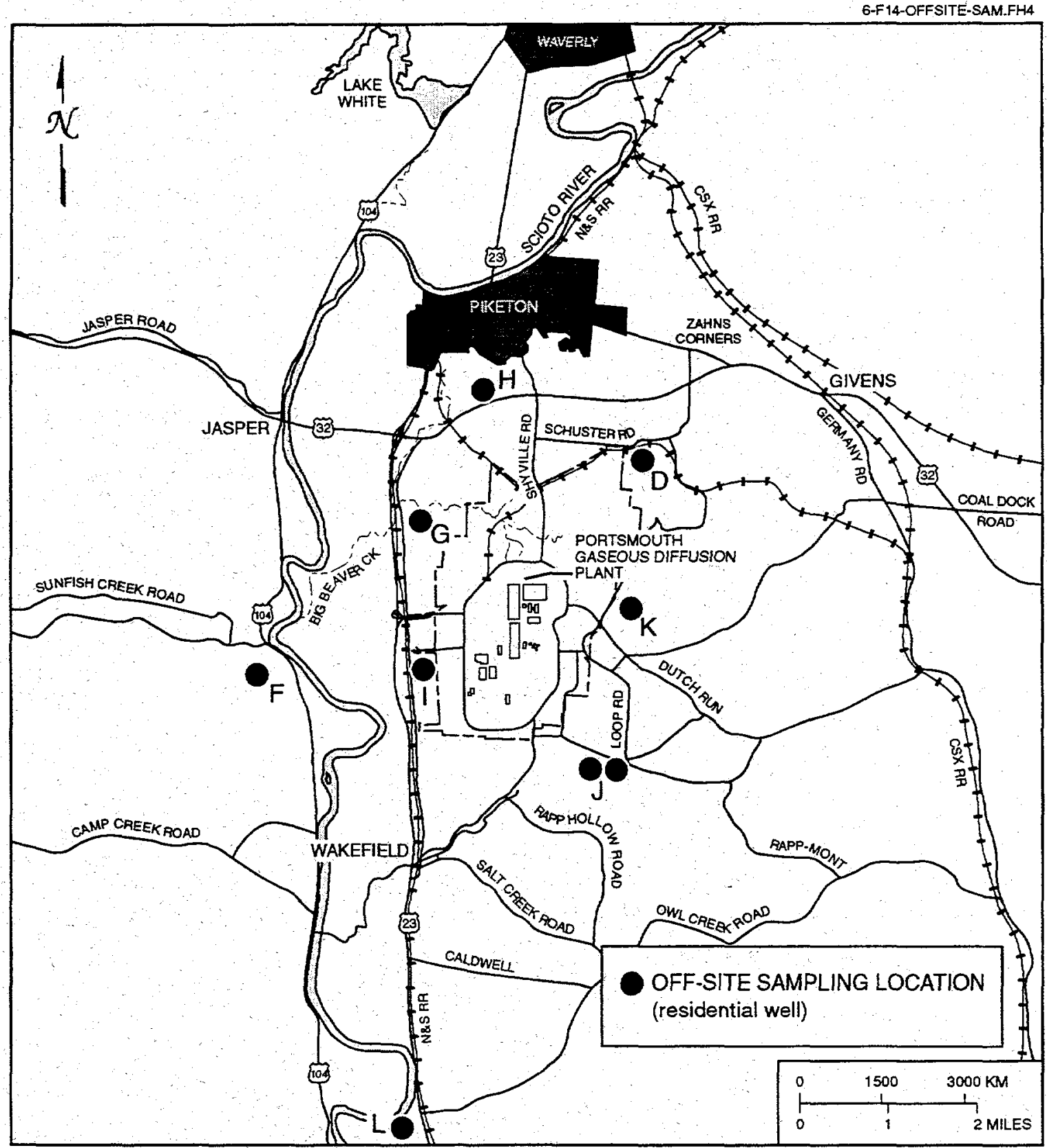

Fig. 6.14. Portsmouth off-site sampling locations. 
grasses. No manifests or records exist that characterize the material in the landfill. In addition, construction details and operation records are not available.

In 1994 the portion of Big Run Creek contiguous to the Peter Kiewit landfill was relocated to the east side of the creek valley. An interceptor trench was installed in the old Big. Run Creek channel to capture seeps emanating from the landfill. Contaminated water from the interceptor trench is processed at the X-622 groundwater treatment facility.

Two wells (Gallia well PK-12G and Berea well PK-13B) were installed in 1995 north of the seep zone to monitor the groundwater. Semiannual sampling results indicated that vinyl chloride (a VOC) was detected once in only one well (Berea) at a concentration of $4 \mathrm{ppb}$. The total uranium concentration ranged from 15 to $40 \mathrm{ppb}$ (Berea), and no technetium was detected.

\section{RCRA Facility Investigations for Quadrants I-IV}

The DOE/PORTS Consent Decree issued by the Ohio Attorney General's Office on August 29, 1989, and the RCRA, 3008(h), Consent Order issued by USEPA Region V on September 29, 1989, outline requirements and schedules for the RFI. These documents include specific dates and specifications for deliverables that must be complied with throughout the RFI, the CMS, and CMI.

Groundwater investigative activity is based on guidelines for a RCRA corrective action plan. However, because DOE/PORTS is large, complex, and resource intensive, the plan was implemented in four parts called "quadrants." The quadrants divide the plant site into four geographic areas based roughly on groundwater divides and drainage patterns. These quadrants (QI, QII, QIII, and QIV) and associated drainages are identified in Figure 6.16. Parallel efforts to provide comprehensive definitions of geology and the hydrologic flow systems provide cohesiveness to this four-part approach.

Field work for quadrants I (QI) and II (QII) was completed in fall 1991. During the QI and QII RFIs, 103 monitoring wells were installed and 149 soil borings were drilled. The QI and QII RFIs provided separate investigations of 34 SWMUs. The results and conclusions are included in the Quadrants I and II Draft Reports dated June 1994. Contaminated groundwater plumes were discovered emanating from the following units: (1) the X-120 Goodyear Training Center (Figure 6.12); (2) X-231A southeast oil biodegradation plot (Figure 6.10 ); (3) X-710 neutralization pit, X-710 "hot pit", and X-760 neutralization pit (Figure 6.10); and (4) the X700 chemical cleaning facility, X-705 decontamination building, and X-7.20 maintenance and stores building (Figure 6.6).

A total of 18 SWMUs were investigated in the QIII RFI. As part of the investigation, 14 wells were installed, 44 soil borings and 93 hand augers were completed, 36 sediment samples were taken, and two surface water sampling sites were monitored. Additional sampling was completed in 1994 to support the RFI and the CMS. The results and conclusions are included in the Quadrant III Draft Report dated November 1994.

A total of 24 SWMUs were investigated in the QIV RFI. As part of this investigation, 49 wells were installed, 80 soil borings and 85 hand augers were completed, and 85 sediment samples were collected. Additional sampling was completed in 1994 to support the RFI and the CMS. The results and conclusions are included in the Quadrant IV Draft Report dated November 1994.

\section{X-120 Goodyear Training Center Contaminant Plume}

The $\mathrm{X}-120$ Goodyear training center consisted of several utility and storage buildings used during construction of the Portsmouth site in the 1950 s and were subsequently removed. The plume associated with 


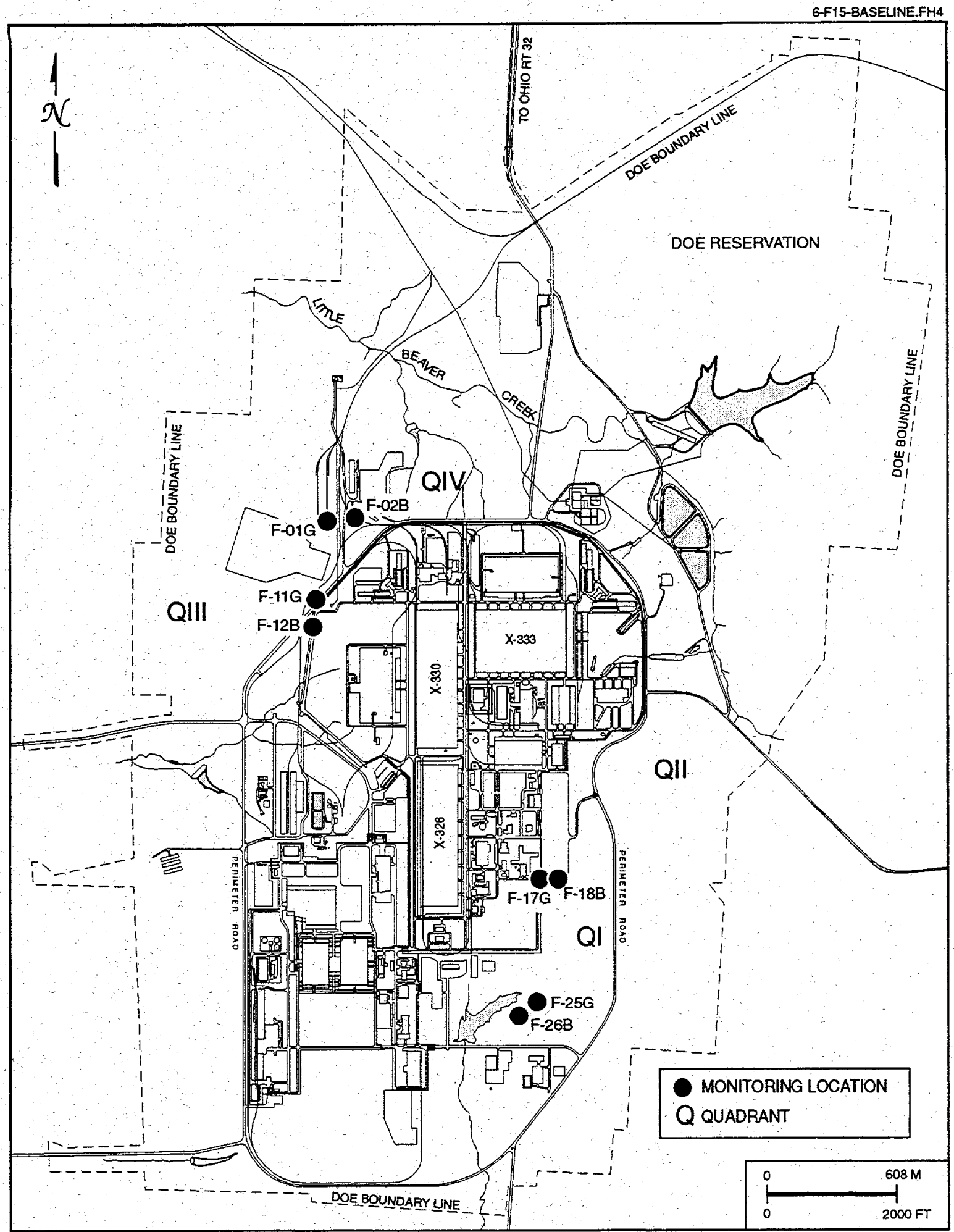

Fig. 6.15. Baseline well monitoring locations at DOEJPORTS. 
the X-120 Goodyear training center consists of TCE; $1,200 \mathrm{ppb}$ was the highest concentration detected. In 1989 TCE concentrations of 800 and $100 \mathrm{ppb}$ were detected in two groundwater wells at this location. Initially, this contamination was presumed to be associated with the X-749 contaminated materials disposal facility; however, results from the QI RFI indicated that the contamination is independent of the X-749 facility.

During the QI RFI, TCE was detected in four wells at concentrations ranging from 18 to $1,200 \mathrm{ppb}$. The long and narrow TCE contaminant plume associated with the X-120 facility originates south of Hewes Street and extends approximately $1,400 \mathrm{ft}$ to the southwest (Figure 6.12); the southeastern edge of the plume nearly converges with the plume emanating from the $\mathrm{X}-749$ contaminated materials disposal facility.

\section{X-120 Groundwater Treatment Facility (X-625X)}

The X-625X groundwater treatment facility building was constructed between June and November of 1995 at X-120 to investigate a new reactive barrier groundwater treatment technology (Figure 6.16). The X120 reactive barrier process will use a horizontal well designed to bring TCE-contaminated groundwater into contact with iron filings. The iron filings will react with the TCE, breaking it down into nonhazardous components. Once the breakdown occurs, the groundwater can be safely discharged into a nearby drainage ditch, monitored under DOE/PORTS's NPDES permit. Installation of the horizontal well is expected to be completed in 1996.

\section{X-231A Southeast Oil Degradation Area Contaminant Plume}

The plume associated with the $\mathrm{X}-231 \mathrm{~A}$ southeast oil degradation area is composed of TCE, TCA, DCE, and DCA. The highest VOC concentration is TCE at $120 \mathrm{ppb}$. All non-TCE contaminants are contained within the TCE plume. The TCE plume has a semicircular shape extending from the south side of X-231A area (Figure 6.10).

\section{X-710 Neutralization Pit, X-710 Hot Pit, and X-760 Neutralization Pit Contaminant Plume}

The plume associated with the $X-710$ neutralization pit, the $X-710$ hot pit, and the $X-760$ neutralization pit is composed mainly of TCE, with minor amounts of TCA and DCE. The highest level of TCE was $1,600 \mathrm{ppb}$, the highest level of DCE was $21 \mathrm{ppb}$, and the highest level of TCA was $5 \mathrm{ppb}$. Contaminants from these two units combine to form a single indistinguishable plume situated almost due south of the X-710 technical services building, under the $X-600 \mathrm{~A}$ coal pile yard, $X-621$ coal pile runoff treatment facility, and the $\mathrm{X}-749 \mathrm{~A}$ classified material burial grounds. This plume coalesces with the $\mathrm{X}-231 \mathrm{~B}$ southeast oil biodegradation area plume shown in Figure 6.10 . The $X-710$ neutralization pit and the $X-710$ hot pit are both located just north of well X231B-36G. VOC contamination was not detected in any Berea sandstone monitoring wells in this area. 


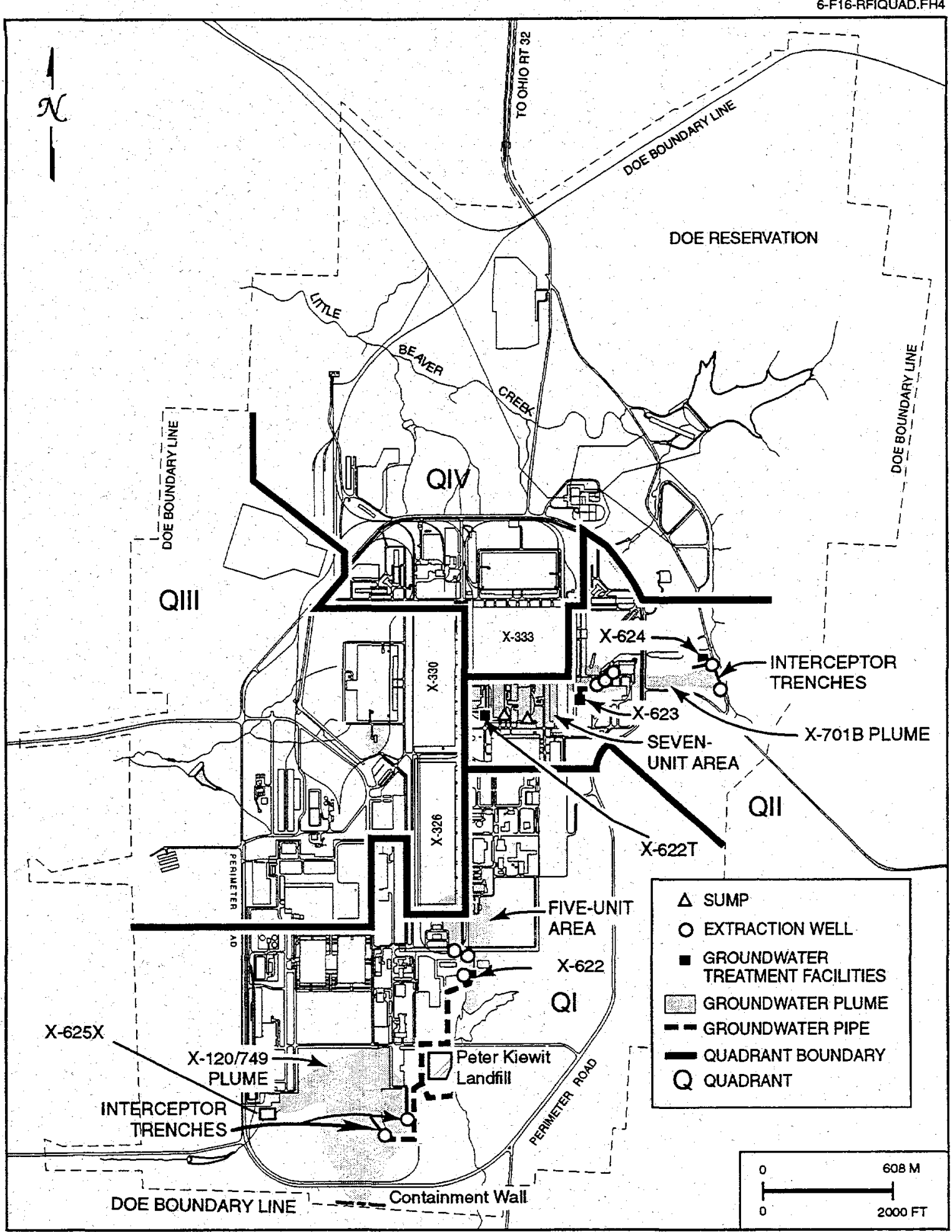

FIG. 6.16. RFI quadrants and associated drainages at DOE/PORTS. 


\section{X-700 Chemical Cleaning Facility, X-705 Decontamination Building, and X-720 Neutralization Pit Contaminant Plume}

The plume associated with the $X-700$ chemical cleaning facility, $X-700$ chemical and petroleum storage containment tanks, X-700 TCE/TCA outside storage tank, X-705 decontamination building, and the $X-720$ neutralization pit is composed primarily of TCE, with a maximum concentration of $19,000 \mathrm{ppb}$. Secondary VOC contaminants are TCA, DCE, chloroform, and methylene chloride. All VOC contaminant plumes are contained within the boundaries of the TCE plume.

\section{Groundwater Treatment Units}

In 1995 a combined total of approximately 18.7 million gallons of contaminated groundwater were treated at the X-622 south groundwater treatment facility (Figure 6.19), X-622T treatment trailer (Figure 6.6), the X-623 groundwater treatment facility (Figure 6.9), and the X-624 Little Beaver groundwater treatment facility (Figure 6.9). Approximately 100 gallons of TCE were removed from the groundwater, which represents a $20 \%$ decrease from 1994. All processed water is discharged through NPDES outfalls before exiting the Portsmouth site.

\section{X-622 South Groundwater Treatment Facility}

The groundwater treatment used at the X-622 south groundwater treatment facility is activated carbon and green sand filtration of the contaminated groundwater. TCE-contaminated groundwater from the X-231B southwest oil biodegradation plot, the X-749 contaminated materials disposal facility, and the Peter Kiewit groundwater collection system are processed at this treatment unit. In 1995 the unit processed approximately 5.9 million gallons of groundwater, and less than one gallon of TCE was removed.

\section{X-622T Groundwater Treatment Trailer}

At the $\mathrm{X}-622 \mathrm{~T}$ treatment trailer, activated carbon is used to treat contaminated groundwater from the $X-700$ chemical cleaning facility and the $X-705$ decontamination building. The $X-700$ and $X-705$ buildings are located above a VOC contaminant groundwater plume, and contaminated groundwater is extracted from sumps located in the basement of each building. In 1995, approximately 9.9 million gallons of groundwater were processed, and about 23 gallons of TCE were removed.

\section{X-623 Groundwater Treatment Facility}

The X-623 groundwater treatment facility consists of an air stripper with off-gas activated carbon filtration and aqueous phase activated carbon filtration. The $X-623$ groundwater treatment facility provides treatment for TCE-contaminated groundwater from the $X-701 \mathrm{~B}$ holding pond and three groundwater extraction wells in the $X-701 \mathrm{~B}$ plume area. The air stripping facility treated approximately 200 thousand gallons of water in 1995, and about 21 gallons of TCE were removed. 


\section{X-624 Little Beaver Groundwater Treatment Facility}

At the X-624 Little Beaver groundwater treatment facility, groundwater is treated via an air stripper with off-gas activated carbon filtration plus carbon filtration of the effluent water. This facility processes TCE-contaminated groundwater from the X-237 interceptor trench associated with the X-701B plume. In 1995 about 2.8 million gallons of groundwater were treated, and about 56 gallons of TCE were removed.

\section{Background Sampling}

The USEPA and the Ohio EPA have requested that background metal concentrations be determined from a statistically significant number of samples taken in off-site geologic and hydrogeologic settings similar to those existing on-site. The off-site background sampling was conducted in 1994. Based on the results of the background sampling, upper tolerance limits were proposed for total mobile metals in the Gallia and Berea groundwater. Upper tolerance limits represent the maximum concentration of naturally occurring constituents that could be expected (i.e., to a $95 \%$ confidence level, $95 \%$ of all possible sample measurements would be less than the upper tolerance limit).

\section{GROUNDWATER MONITORING RESULTS}

The results for groundwater monitoring activities at DOE/PORTS are discussed briefly under "Groundwater Monitoring at Portsmouth." However, for regularly scheduled compliance monitoring, a more detailed discussion of the results follows.

\section{RCRA Units}

The following DOE/PORTS RCRA units are included in detection monitoring or assessment monitoring. Historical trends of groundwater contamination are important because changes in groundwater contaminant values help indicate the direction and rate of contaminant migration. Of particular importance are wells that show significant increases or decreases in concentrations or contamination that occur in previously clean wells. A significant increase can be defined as an annual mean concentration that is at least two standard deviations higher than the previous year's mean.

\section{X-701B Holding Pond}

\section{VOC Contamination}

The primary VOC contaminant at X-701B is TCE, which is limited to the Gallia sand. All other contamination is contained within the extent of the TCE plume. Sampling results from wells at X-701B show that the french drain and extraction pumps installed near Little Beaver Creek in 1991 have also affected the contaminant migration plume near X-701B. Monitoring wells located near the edges of the existing contaminant plume show decreasing TCE concentrations in all but one well (see Figure 6.17). Upgradient monitoring wells are not showing an increase because the TCE sources are located within the plume outline. Groundwater 


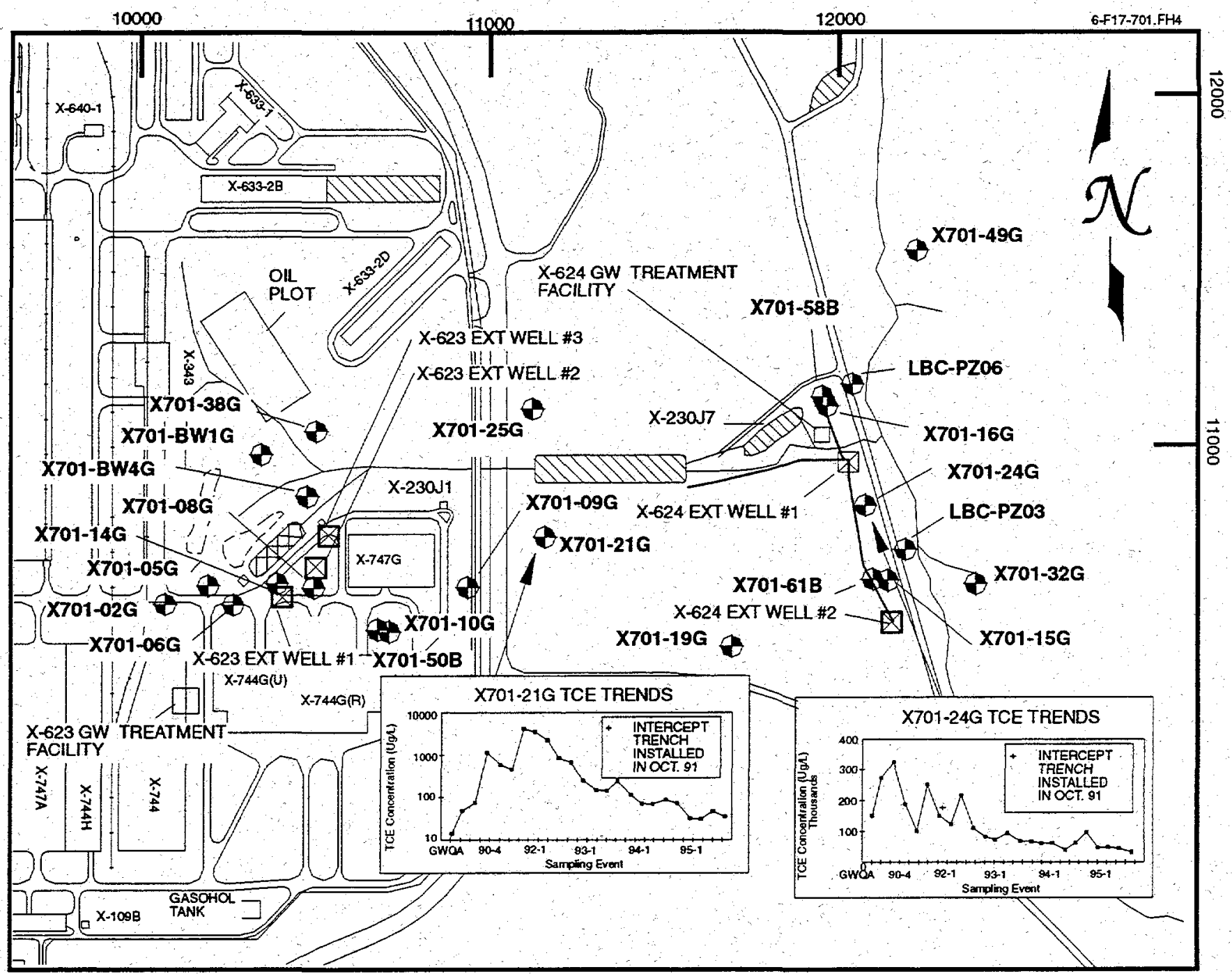

Site Location

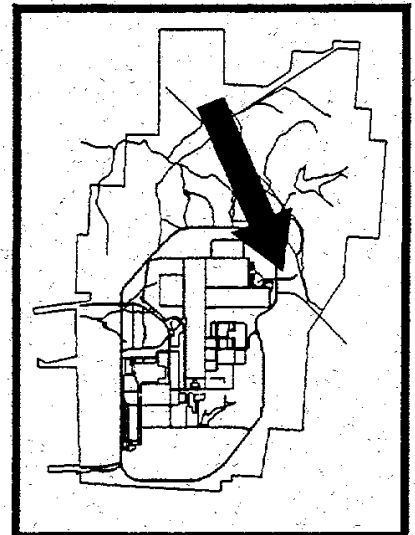

LEGEND

\begin{tabular}{ll}
\hline$X 17$ & $\begin{array}{l}\text { Interceptor trench } \\
\text { Water Bodies }\end{array}$ \\
\hline$\times 701-02 G$ & $\begin{array}{l}\text { Creeks, Streams } \\
\text { RCRA monitoring well }\end{array}$ \\
$\square$ & Extraction well \\
& RCRA unit
\end{tabular}

Fig 6.17. X-701B holding pond trends in TCE concentrations at selected wells. 
flow velocities and flow direction have remained constant since 1991 . Three of the X-701B wells had a significant change in TCE concentration (i.e., a 1995 mean concentration more than two standard deviations higher or lower than the 1994 mean concentration). The annual mean TCE concentration decreased at well X701-08G, which is near the center of the plume and at well X701-21G, which is downgradient of the source. There was an increase in the mean TCE concentration at well X701-10G. This may indicate movement of the center of the plume. TCE was not detected in groundwater samples from Berea monitoring wells. The fiveyear trend at wells X701-21G and 24G indicate that the mean TCE concentration continues to decrease over most of the area.

\section{Radiological Contamination}

Radiological results for 1995 were elevated over 1994 results in some of the Gallia wells located in the X-701B TCE plume (X701-06G, and X701-21G). An increase in annual mean gross beta activity was observed in well X701-06G, and technetium annual mean activity was higher in well X701-21G. Radiological results from Berea wells at X-701B showed little change from 1994.

\section{X-749 Contaminated Materials Disposal Facility}

\section{VOC Contamination}

VOC contamination in the Gallia at X-749 is composed primarily of TCE, TCA, DCE, DCA, Freon113 , chloroform, and vinyl chloride. TCE concentrations increased at X749-04G. TCE and TCA concentrations decreased at monitoring wells X749-10G, X749-25G, and X749-26G. Freon-113 concentrations increased at well X749-36G. DCA concentrations increased at wells X749-PZ04G, X749-10G, X749-13G, and X749-08G.

The only VOCs detected in the Berea were DCAs (maximum concentration of $7 \mathrm{ppb}$ ) at well X74950B. This result is similar to 1994 data, at which time it was suspected that limited cross-contamination from the Gallia could have occurred during installation of the well because the well is screened beneath the Gallia VOC plume. However, the annular seal of the well was investigated and found to be intact, so additional cross-contamination should not occur. Therefore, as concluded in last year's report, the VOC concentrations in this well are thought to be remnants of the original cross-contamination. The five-year trend in TCE concentrations at two X-749 wells is shown in Figure 6.18.

\section{Radiological Contamination}

In 1995 the gross beta activities for X749-08G, X749-13G, X749-25G, and X749-32G decreased. Technetium activities decreased in wells X749-06G and X749-32G. Uranium concentrations decreased in wells X749-PZ05G and X749-60B. Gross alpha concentrations increased in well X749-60B and decreased in well X749-PZ05G. The radionuclide results for the remaining Gallia wells were relatively unchanged from 1994; likewise, results of the Berea radiochemical analyses were similar to the 1994 results. 


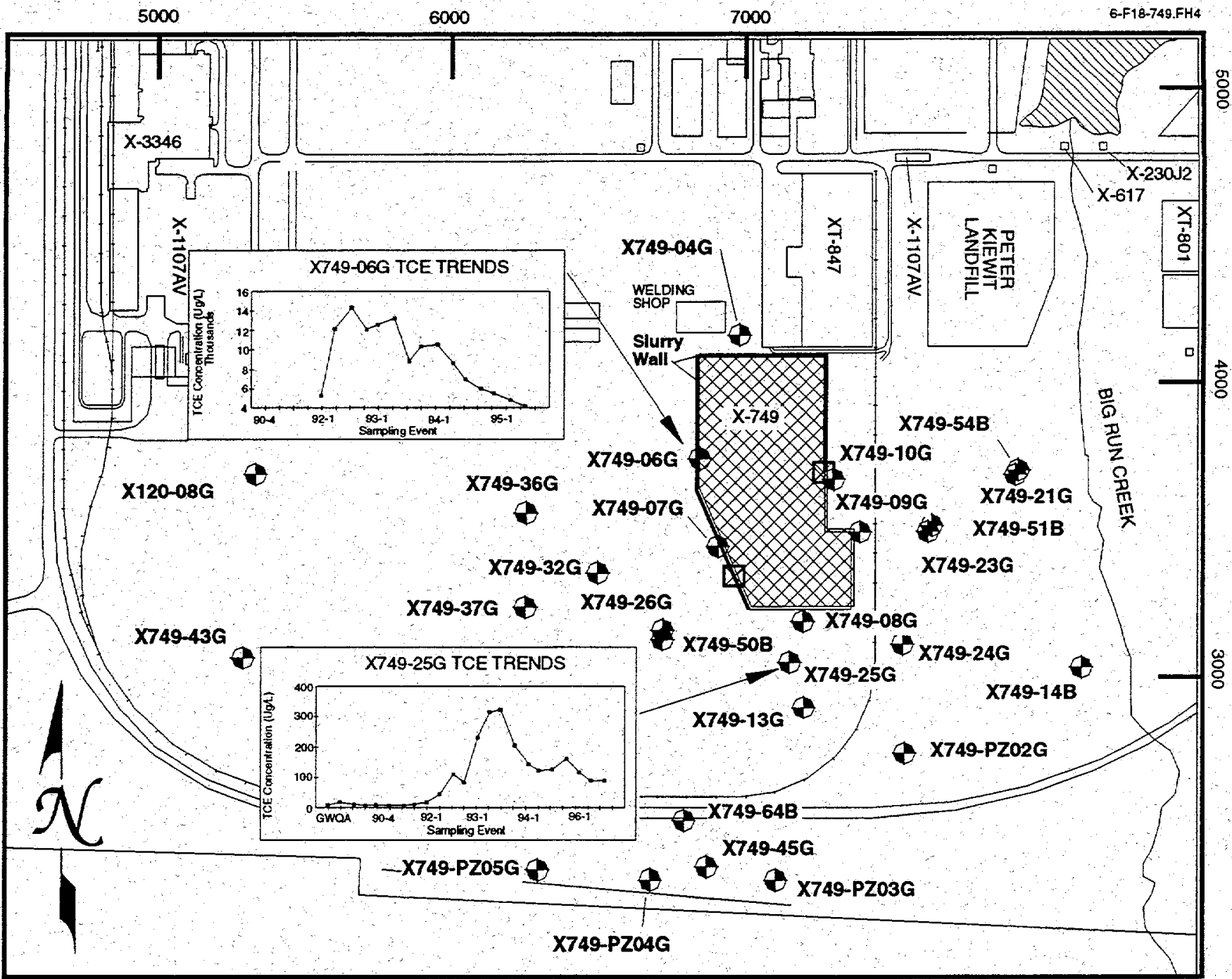

\section{Site Location}

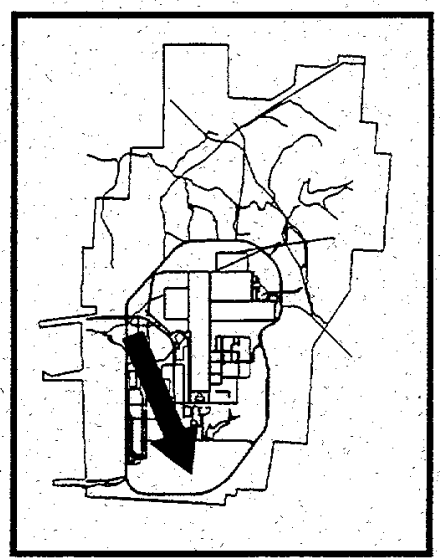

LEGEND

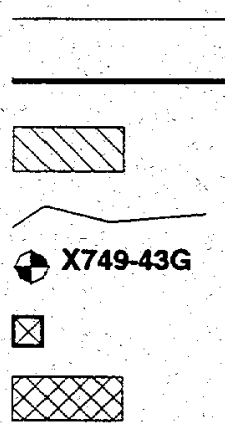

Interceptor trench

Slurry wall

Water bodies

Creeks Streams

RCAA monitoring well

Extraction well

RCRA unit

Fig 6.18. X-7.49 contaminated materials disposal facility trends in TCE concentrations. 


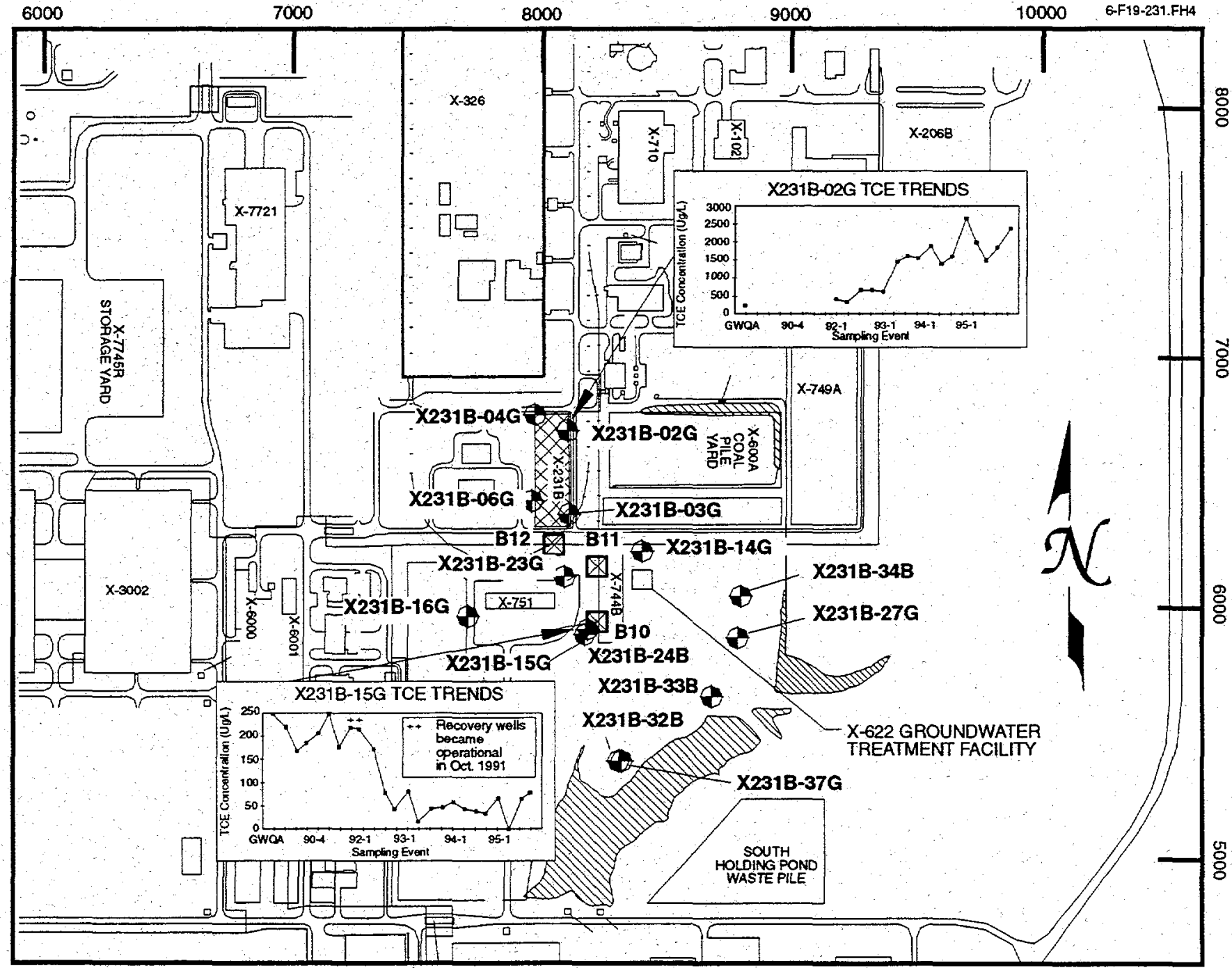

Site Location

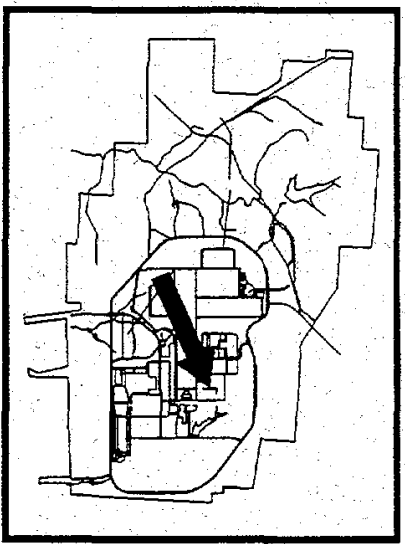

LEGEND
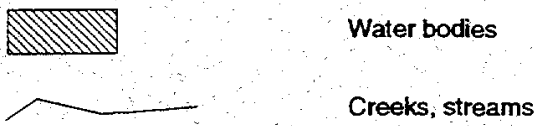

X231B-04G RCRA monitoring well

冈 Extraction well

XXXX RCRA unit

Fig 6.19. X-231B southwest oil biodegradation plot trends in TCE concentrations. 


\section{X-231B Southwest Oil Biodegradation Plot}

\section{VOC Contamination}

The primary VOC contaminant at X-231B is TCE; minor VOC constituents include TCA and DCE. In the Gallia, TCE concentrations increased significantly in 1995 in only one well, X231-04G. DCE and TCA concentrations decreased in well X231B-06G. The Berea wells at X-231B are not affected by VOC contamination. The five-year trend in TCE concentrations at two X-231B wells is shown in Figure 6.19.

\section{Radiological Contamination}

Radiological results for 1995 in Gallia wells were generally lower than 1994 values. Radiological results from Berea wells at X-231B showed higher uranium concentrations in well X231-34B.

\section{X-616 Chromium Sludge Surface Impoundments}

\section{VOC Contamination}

VOC contamination in the Gallia and Berea at X-616 wells is composed primarily of TCE and TCA. VOC contamination was detected in 1995 in both the Gallia sand and the Berea sandstone at three neighboring wells (X616-09G, X616-16G, and X616-20B). Compared to 1994 results, the TCE concentration decreased in well X616-09G. The small area of contamination appears to be centered near the southwest corner of the X-616 surface impoundment. The source of the VOCs may be the nonoperational X-615 sewage treatment unit or an associated adjacent sewage line.

\section{Metals Contamination}

Chromium was the primary contaminant of concern at X-616. Both dissolved chromium (filtered) and total chromium (unfiltered) samples are collected at X-616. In 1995 concentrations of dissolved chromium were generally the same as 1994, except for well X616-05G, which was significantly lower. 1995 concentration results for total chromium increased in wells X616-05G, X616-16G, X616-25G, and X616-19B. This trend in the Gallia is similar to that observed for VOCs.

\section{Radiological Contamination}

All radiological results for the $\mathrm{X}-616$ wells were below the proposed action levels. (Proposed action levels are listed in table footnotes in the DOE/PORTS Annual Report for 1995 Groundwater Monitoring, March 1996.)

\section{X-701C Neutralization Pit}

\section{VOC Contamination}

Results for 1995 show little change compared to 1994 . VOC contamination in the Gallia at X-701C wells is composed primarily of TCE. 


\section{Radiological Contamination}

Results for 1995 show little change compared to 1994 . Technetium and gross beta concentrations decreased slightly in well X701-70G.

\section{X-735 Landfill}

\section{voc Contamination}

Results for 1995 show little change compared to 1994. Except for one detection of carbon disulfide (a typical laboratory contaminant) in well X735-20B, no VOCs were detected in Gallia or Berea wells in X-735.

\section{Radiological Contamination}

Results for 1995 show little change compared to 1994. Except for uranium in well X735-19G, no radiological contamination was detected at concentrations above the proposed action levels.

\section{Metals Contamination}

Cadmium, chromium, lead, and nickel were detected above their MCLs. At one well, the detected dissolved cadmium concentration was $5.5 \mathrm{ppb}$; however, the total cadmium concentration was less than the detection limit $(2.9 \mathrm{ppb})$. These data are inconsistent but do indicate a release. Except for this cadmium result, the dissolved metal concentrations in the upgradient well are either comparable to the downgradient well, occurred in only one sampling event, or are higher than the downgradient well.

\section{Surface Water}

Surface water monitoring for Little Beaver Creek, the East Drainage Ditch, North Holding Pond, Big Run Creek, the unnamed southwest drainage ditch, and the West Drainage Ditch is conducted as part of assessment monitoring at X-701B, X-749, X-231B, and X-616. The results discussed in this section pertain only to surface water monitoring conducted in support of the DOE/PORTS GWPP.

\section{voc Contamination}

The concentration of VOCs (primarily TCE) in the East Drainage Ditch and Little Beaver Creek near the X-701B contaminant plume has decreased since the interceptor trench (X-237) for the plume was installed in October 1991. TCE has not been detected in Little Beaver Creek since the second quarter of 1994. At an unnamed southwest drainage ditch sampling site, UND-SW01, TCE was detected at a higher concentration than in 1994. TCE was not detected in Big Run Creek, the North Holding Pond, or the West Drainage Ditch in 1995 . 


\section{Radiological Contamination}

Radiological results for 1995 were below the proposed action levels for all surface water locations. There were no detectable technetium levels in any of the surface water locations. None of the surface water monitoring sites showed statistically significant changes for radiological results in 1995. 



\title{
7. Quality Assurance
}

\begin{abstract}
Quality assurance is an integral part of environmental surveillance at DOE/PORTS. Quality control (QC) is part of sampling and monitoring in the field as well as analytical work performed in the Portsmouth analytical laboratory. The Portsmouth analytical laboratory has its own internal QC program and participates in external QC programs administered by the U.S. Environmental Protection Agency, DOE, and commercial laboratories. Of the 2,146 external QC measurements made by the Portsmouth laboratory in 1995, 98.1\% of the results were acceptable. The Performance Assurance Division performs program assessment activities in the field and within facilities at regular intervals to further assure quality is built into the program and is maintained.
\end{abstract}

\section{INTRODUCTION}

Quality assurance (QA), an integral part of the environmental surveillance effort, requires systematic control of the processes involved in sampling the environment and in analyzing the samples. To achieve the desired level of competence, DOE/PORTS uses the following major types of planned and systematic controls:

- implementation of standard operating procedures for sample collection and analysis,

- surveyor and analyst training and qualification,

- implementation of sample tracking and chain-of-custody procedures to ensure traceability and integrity of samples and data,

- participation in external quality control (QC) programs,

- frequent calibration and routine maintenance of measuring and test equipment,

- maintenance of internal QC programs,

- implementation of good measurement techniques and good laboratory practices, and

- frequent assessment of field sampling, measurement activities, and laboratory processes.

Environmental sampling at DOE/PORTS is conducted by members of the Waste Management Division. Sampling plans and procedures are prepared, and appropriate sampling instruments or devices are selected in accordance with practices recommended by the USEPA, the American Society for Testing and Materials, or other authorities. Chain-of-custody documentation is prepared from the point of sampling. The samples remain in the custody of the sampling group until they are transferred to the sample custodian at the Portsmouth laboratory.

An administratively independent QA manager has general oversight responsibility for all phases of laboratory QA in the Portsmouth analytical laboratory. The QA manager is also responsible for the activities of the Laboratory Controls and Standards Group and administration of external and internal control programs. The Laboratory Controls and Standards Group generates internal QC samples using materials from the National Institute of Standards and Technology (NIST) or other reliable source materials. The samples are then submitted to the laboratories at an established frequency. Two laboratory statisticians provide support to the laboratory's QA efforts by performing statistical evaluations and administering the control chart program. Good measurement practices used by laboratory personnel include use of matrix spikes, matrix spike dupli- 
cates, replicate samples, check samples, and various other internal controls. The extensive internal QC program helps ensure reliability of the analytical data on a day-to-day basis.

Environmental Compliance personnel track and interpret analytical results. Responsibility for interpreting and tracking environmental data is divided because of the large amount of surveillance information generated. Data are reviewed when made available to ascertain compliance with applicable regulations. In some instances, remedial action may be warranted. The data are reviewed periodically for overall interpretation and, where relevant, for their interprogram relationships. Documentation of these efforts serves as a resource for future activity.

\section{FIELD SAMPLING AND MONITORING}

Personnel involved in field sampling and monitoring are properly trained. They use approved procedures developed from guidelines and regulations promulgated by DOE or other regulatory agencies exercising authority over DOE/PORTS activities. These procedures specify sampling protocol, sampling devices, and containers and preservatives to be used. Chain-of-custody procedures (used with all samples) are documented, and samples are controlled and protected from the point of collection to the generation of analytical results.

\section{Basic Concepts and Practices}

Because data generated from field sampling can be greatly influenced by the methods used to collect and transport the samples, it is imperative that a QA program be in place to ensure that the samples are collected properly and represent the conditions that exist in the environment at the time of sampling. The DOE/PORTS QA program mandates compliance with written sampling procedures, using clean sampling devices and containers, employing approved sample-preservation techniques, and submitting field blanks and duplicate samples. Chain-of-custody procedures are strictly followed to ensure that sample integrity is maintained. Samples are delivered to the laboratory as soon as practicable after collection to ensure sample integrity.

\section{Surface Water Monitoring}

Liquid effluent streams from DOE/PORTS are sampled and analyzed in compliance with the NPDES discharge permit. Written procedures are used as guides for both sampling and analysis of effluent streams. Flow and $\mathrm{pH}$ are measured and recorded at several discharge points.

\section{Groundwater Monitoring}

The DOE/PORTS groundwater monitoring program requires the use of disposable Teflon bailers to reduce the risk of cross-contamination of wells and samples. Written procedures are followed when collecting and analyzing samples. Field blanks and duplicate samples are also submitted to the laboratory to ensure that sampling techniques are not influencing the data being collected.

\section{ANALYTICAL QUALITY ASSURANCE}

The Portsmouth analytical laboratory continues a long tradition of QA and has a well-established QA program. Integral to this program are a highly trained, well-qualified staff; use of approved written procedures 
and current analytical methodology; availability of excellent equipment and facilities; well-established inhouse surveillance, noncompliance reporting, and corrective action programs; and routine use of accepted laboratory practices and measurement techniques. As part of the QA effort, the analytical laboratory maintains comprehensive internal QC programs, participates in a number of external QC programs; and extensively uses statistical interpretation to evaluate its performance.

The laboratory QA program is based on the QA/QC requirements mandated by the Ohio EPA, the USEPA, and DOE. Analyses are performed using USEPA-approved methods. Other reliable methods are used when USEPA methods are not available.

During 1994 the Portsmouth laboratory was reaccredited as an American Industrial Hygiene Association Industrial Hygiene Laboratory. In addition, the lab has maintained accreditation from NIST for bulk asbestos fiber analysis under the National Voluntary Laboratory Accreditation Program.

\section{Internal Quality Control}

Internal QC programs at the Portsmouth laboratory are the basis for ensuring reliable analytical results on a day-to-day and batch-to-batch basis. In accordance with USEPA expectations, the total QC effort in these programs averages from $10 \%$ to $20 \%$ of the total laboratory effort Internal QC programs, which include both known and blind controls, are routinely administered by the Laboratory Controls and Standards Group independently of the analytical laboratories. Statistical evaluation of the QC programs is performed by the laboratory statistician.

All analytical activities are supported by the routine use of either standard or reference materials from NIST, the USEPA, other DOE laboratories, or reliable commercial sources. QC is accomplished through the use of such standards or reference materials for instrument calibrations; preparation of known, blind, and double-blind controls; yield/efficiency determinations; and spike recoveries. Numerous process control charts maintained by the laboratory assist in assessing the adequacy of analytical programs and procedures. If serious deviations are noted, noncompliance reports are initiated, investigations are conducted, and corrective actions are implemented. QC data can be retrieved when necessary to support the analytical results.

\section{External Quality Control}

In addition to the internal QC programs, the Portsmouth laboratory regularly participates in external QC programs. These programs, which are administered by the USEPA, the National Institute of Occupational Safety and Health (NIOSH), DOE, NIST, and commercial laboratories, generate data that serve as a periodic indicator of performance. Results are usually characterized as being acceptable, marginal, or unacceptable. For purposes of the summary that follows, marginal results are included in the acceptable category. Unacceptable results in external control programs are investigated through either the surveillance program or the nonconformance reporting program, and corrective actions are implemented as warranted. A summary of the Portsmouth analytical laboratory's performance in external QC programs from 1991 through 1995 is shown in Table 7.1.

\section{Radiological Quality Control}

In 1995 the Portsmouth analytical laboratory participated in three external radiological QC programs: the USEPA Intercomparison Radionuclide Control Program, administered by the USEPA Environmental Monitoring Systems Laboratory at Las Vegas (EMSL-LV), the DOE Environmental Measurements Laboratory (EML) Radionuclide Quality Assessment Program, and the DOE Mixed Analyte Performance Evaluation 
Table 7.1. Performance summary of the Portsmouth analytical laboratory external quality control programs, 1991-1995.

\begin{tabular}{|c|c|c|c|c|}
\hline \multirow{2}{*}{ Program } & \multirow{2}{*}{ Year } & \multicolumn{3}{|c|}{ Number of measurements } \\
\hline & & Total & Acceptable/marginal (\%) & Unacceptable (\%) \\
\hline $\mathrm{PET}^{\mathrm{A}}$ & $\begin{array}{l}1991 \\
1992 \\
1993 \\
1994 \\
1995\end{array}$ & $\begin{array}{l}1271 \\
1583 \\
1772 \\
1659 \\
1468\end{array}$ & $\begin{array}{l}1243(98) \\
1564(99) \\
1752(99) \\
1631(98) \\
1447(99)\end{array}$ & $\begin{array}{l}28(2) \\
19(1) \\
20(1) \\
28(2) \\
21(1)\end{array}$ \\
\hline EMSL-LV & $\begin{array}{l}1991 \\
1992 \\
1993 \\
1994 \\
1995\end{array}$ & $\begin{array}{l}19 \\
19 \\
16 \\
16 \\
16\end{array}$ & $\begin{array}{l}17(90) \\
18(95) \\
12(75) \\
14(88) \\
16(100)\end{array}$ & $\begin{array}{c}2(10) \\
1(5) \\
4(25) \\
2(12) \\
0(0)\end{array}$ \\
\hline $\mathrm{EMI}^{\mathrm{c}}$ & $\begin{array}{l}1991 \\
1992 \\
1993 \\
1994 \\
1995\end{array}$ & $\begin{array}{l}42 \\
41 \\
60 \\
69 \\
71\end{array}$ & $\begin{array}{c}41(98) \\
41(100) \\
60(100) \\
66(96) \\
70(99)\end{array}$ & $\begin{array}{l}1(2) \\
0(0) \\
0(0) \\
3(4) \\
1(1)\end{array}$ \\
\hline$D M R-Q A^{d}$ & $\begin{array}{l}1991 \\
1992 \\
1993 \\
1994 \\
1995\end{array}$ & $\begin{array}{l}20 \\
19 \\
16 \\
17 \\
17\end{array}$ & $\begin{array}{l}19(95) \\
17(89) \\
15(94) \\
17(100) \\
17(100)\end{array}$ & $\begin{array}{l}1(5) \\
2(11) \\
1(6) \\
0(0) \\
0(0)\end{array}$ \\
\hline $\operatorname{PAT}^{e}$ & $\begin{array}{l}1991 \\
1992 \\
1993 \\
1994 \\
1995\end{array}$ & $\begin{array}{l}128 \\
128 \\
128 \\
128 \\
120\end{array}$ & $\begin{array}{c}120(94) \\
126(98) \\
128(100) \\
128(100) \\
112(93)\end{array}$ & $\begin{array}{l}8(6) \\
2(2) \\
0(0) \\
0(0) \\
8(7)\end{array}$ \\
\hline$w^{f}$ & $\begin{array}{l}1992 \\
1993 \\
1994 \\
1995\end{array}$ & $\begin{array}{c}97 \\
227^{\mathrm{h}} \\
243 \\
269\end{array}$ & $\begin{array}{l}82(85) \\
215(95) \\
228(88) \\
259(96)\end{array}$ & $\begin{array}{c}15(15)^{\mathrm{g}} \\
12(5) \\
15(12) \\
10(4)\end{array}$ \\
\hline ELPAT & $\begin{array}{l}1993 \\
1994 \\
1995\end{array}$ & $\begin{array}{l}48 \\
48 \\
48\end{array}$ & $\begin{array}{l}48(100) \\
48(100) \\
48(100)\end{array}$ & $\begin{array}{l}0(0) \\
0(0) \\
0(0)\end{array}$ \\
\hline MAPEP & 1995 & 43 & $42(98)$ & $1(2)$ \\
\hline REAL WORLD & 1995 & 94 & $93(99)$ & $1(1)$ \\
\hline Total & $\begin{array}{l}1991 \\
1992 \\
1993 \\
1994 \\
1995\end{array}$ & $\begin{array}{l}1480 \\
1887 \\
2267 \\
2180 \\
2146\end{array}$ & $\begin{array}{l}1440(97) \\
1848(98) \\
2230(98) \\
2130(98) \\
2105(98)\end{array}$ & $\begin{array}{l}40(3) \\
39(2) \\
37(2) \\
50(2) \\
41(2)\end{array}$ \\
\hline
\end{tabular}

${ }^{a}$ Proficiency Environmental Testing Program (Analytical Products Group, Inc.)

${ }^{\circ}$ Environmental Monitoring Systems Laboratory at Las Vegas (USEPA)

Environmental Measurements Laboratory (DOE).

Discharge Monitoring Report Quality Assurance Study (USEPA)

'Proficiency Analytical Testing Program (NIOSH).

'Water Pollution Performance Evaluation Study (USEPA).

${ }^{8}$ Eleven of the fifteen outliers occurred because of the cross-mixing of control solution vials for WP minerals prior to analysis.

"Excludes three "unusual results" not included in either acceptable or unacceptable categories.

${ }^{3}$ Environmental Lead Proficiency Analytical Testing Program (USEPA, NIOSH, American Industrial Hygiene Association).

${ }^{j}$ Mixed Analyte Performance Evaluation Program

${ }^{\mathrm{k}}$ Real World Matrix Evaluation Program

\section{7-4 Quality Assurance}


Program (MAPEP). In conjunction with the EMSL-LV, 16 analyses were performed on four parameters (alpha and beta activity, total uranium, and plutonium-239) in an aqueous matrix. All sample results were in the acceptable range. Various matrix samples such as water, air filters, soil, tissue, and vegetation are analyzed semiannually for a variety of radioactive isotopes as part of the EML program. In 1995 the Portsmouth laboratory performed a total of 71 analyses in the two rounds of this program (EML 569 and EML 576). The percentage of results in the acceptable range was $99 \%$. In 1995 the Portsmouth analytical laboratory participated in two MAPEP programs in which the percent of acceptable results was $97.7 \%$.

\section{Nonradiological Quality Control}

The Portsmouth laboratory participated in several nonradiological QC programs in 1995, including the Proficiency Environmental Testing Program, the Real World Matrix program, the USEPA Discharge Monitoring Report Quality Assurance Study (DMR-QA), the USEPA Water Pollution Performance Evaluation Study (WP), the NIOSH Proficiency Analytical Testing Program, and the NIOSH Environmental Lead Proficiency Analytical Testing Program.

The Proficiency Environmental Testing (PET) Program and the Real World Matrix program are commercial control programs for environmental analysis sponsored by Analytical Products Group, Inc. (APG), of Belpre, Ohio. For the PET program samples at two concentration levels representing a wide variety of environmental parameters are distributed monthly to laboratories nationwide. Results are statistically evaluated by APG and are issued to participating laboratories. The report includes two evaluations as a measure of performance for each analysis: percent recovery of the reference value (which is based on APG's reference value for the analyte) and deviation from the mean result of all reporting laboratories in the program (which provides a performance comparison with all participants). During 19951,447 analyses representing 76 analytes were performed; of the total results, $98.6 \%$ were deemed acceptable.

The USEPA conducts DMR-QA, a national QA program, in support of the NPDES program. All holders of major NPDES permits are required to participate. The USEPA furnishes QC samples and evaluates the results. During $1995100 \%$ of laboratory results for 17 analytes were deemed acceptable. In addition, results for two parameters ( $\mathrm{pH}$ and residual chlorine) analyzed by the sample group were also acceptable.

The USEPA WP Study includes a wide variety of organic, inorganic, and miscellaneous test parameters applicable to water pollution analyses. The test materials are prepared and distributed from the EMSL in Cincinnati. Results are evaluated by the participating laboratory's USEPA regional office. In rounds WP034 and WP035, the Portsmouth laboratory submitted 269 usable results, $96 \%$ of which were acceptable.

Laboratories nationwide participate in the NIOSH Proficiency Analytical Testing Program. Although its primary purpose is to support safety and health programs, this program includes a number of analyses that represent environmental concerns (i.e., metals, silica, asbestos, and organic solvents). The Portsmouth laboratory achieved 93\% acceptable results for the 120 results submitted during 1995.

The Environmental Lead Proficiency Analytical Testing Program, established in 1992, is a cooperative effort among NIOSH, the USEPA, and the American Industrial Hygiene Association to improve and evaluate the performance of laboratories involved in the analysis of lead in paint, dust, and soil matrices. During 1995 the Portsmouth laboratory participated in all four rounds $(010-013)$ of this program. Acceptability for the 48 results submitted was $100 \%$.

\section{Performance Summary}

During 1995 the Portsmouth laboratory performed 2,146 external control measurements, $98.1 \%$ of which were acceptable. In addition, a total of 21 independent assessments of both field and laboratory facilities were completed with no major findings issued. 



\section{Appendix A: Radiation}

This appendix gives basic facts about radiation. This information is intended as a basis for understanding the dose associated with releases from DOE/PORTS, not as a comprehensive discussion of radiation and its effects on the environment and biological systems. The McGraw-Hill dictionary defines radiation and radioactivity as follows.

radiation-1. The emission and propagation of waves transmitting energy through space or through some medium; for example, the emission and propagation of electromagnetic, sound, or elastic waves. 2 . The energy transmitted through space or some medium; when unqualified, usually refers to electromagnetic radiation. Also known as radiant energy. 3. A stream of particles, such as electrons, neutrons, protons, alpha particles, or high-energy photons, or a mixture of these (McGraw-Hill 1989).

radioactivity - A particular type of radiation emitted by a radioactive substance. such as alpha radioactivity (McGraw-Hill 1989).

Radiation occurs naturally; it was not invented, but rather, was discovered. People are constantly exposed to radiation. For example, radon in air, potassium in food and water, and uranium, thorium, and radium in the earth's crust are all sources of radiation. The following discussion describes important aspects of radiation, including atoms and isotopes; types, sources, and pathways of radiation; radiation measurement; and dose information.

\section{ATOMS AND ISOTOPES}

All matter is made up of atoms. An atom is "a unit of matter consisting of a single nucleus surrounded by a number of electrons equal to the number of protons in the nucleus" (ANS 1986). The number of protons in the nucleus determines an element's atomic number, or chemical identity. With the exception of hydrogen, the nucleus of each type of atom also contains at least one neutron. Unlike protons, the number of neutrons may vary among atoms of the same element. The number of neutrons and protons determines the atomic weight. Atoms of the same element with a different number of neutrons are called isotopes. In other words, isotopes have the same chemical properties but different atomic weights. Figure A.1 depicts isotopes of the element hydrogen. Another example is the element uranium, which has 92 protons; all isotopes of uranium, therefore, have 92 protons. However, each uranium isotope has a different number of neutrons. Uranium-238 (also denoted ${ }^{238} \mathrm{U}$ ) has 92 protons and 146 neutrons; uranium-239 has 92 protons and 147 neutrons; uranium240 has 92 protons and 148 neutrons.

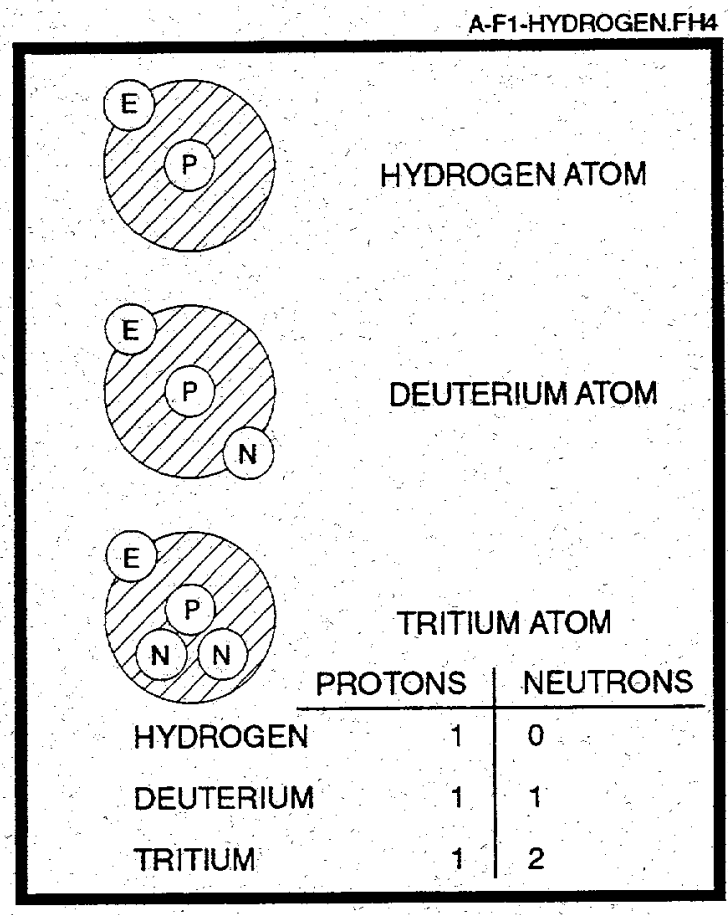

Fig. A.1. Isotopes of the element hydrogen. 
Some isotopes are stable, or nonradioactive; some are radioactive. Radioactive isotopes are called radioisotopes, or radionuclides. In an attempt to become stable, radionuclides "throw away," or emit, rays or particles. This emission of rays and particles is known as radioactive decay.

\section{RADIATION}

Radiation, or radiant energy, is energy in the form of waves or particles moving through space. Visible light, heat, radio waves, and alpha particles are examples of radiation. When people feel warmth from the sunlight, they are actually absorbing the radiant energy emitted by the sun.

Electromagnetic radiation is radiation in the form of electromagnetic waves; examples include gamma rays, ultraviolet light, and radio waves. Particulate radiation is radiation in the form of particles; examples include alpha and beta particles. Radiation also is characterized by the way in which it interacts with matter.

\section{Ionizing Radiation}

Normally, an atom has an equal number of protons and electrons; however, atoms can lose or gain electrons in a process known as ionization. Some forms of radiation can ionize atoms by "knocking" electrons off atoms. Examples of ionizing radiation include alpha, beta, and gamma radiation. Ionizing radiation is capable of changing the chemical state of matter and subsequently causing biological damage and thus is potentially harmful to human health. Figure A. 2 shows the penetrating potential of different types of ionizing radiation.

\section{Nonionizing Radiation}

\section{Nonionizing radiation} bounces off of or passes through matter without displacing electrons. Examples include visible light and radio waves. Currently, it is unclear whether nonionizing radiation is harmful to human health. In the discussion that follows; the term radiation is used to describe ionizing radiation.

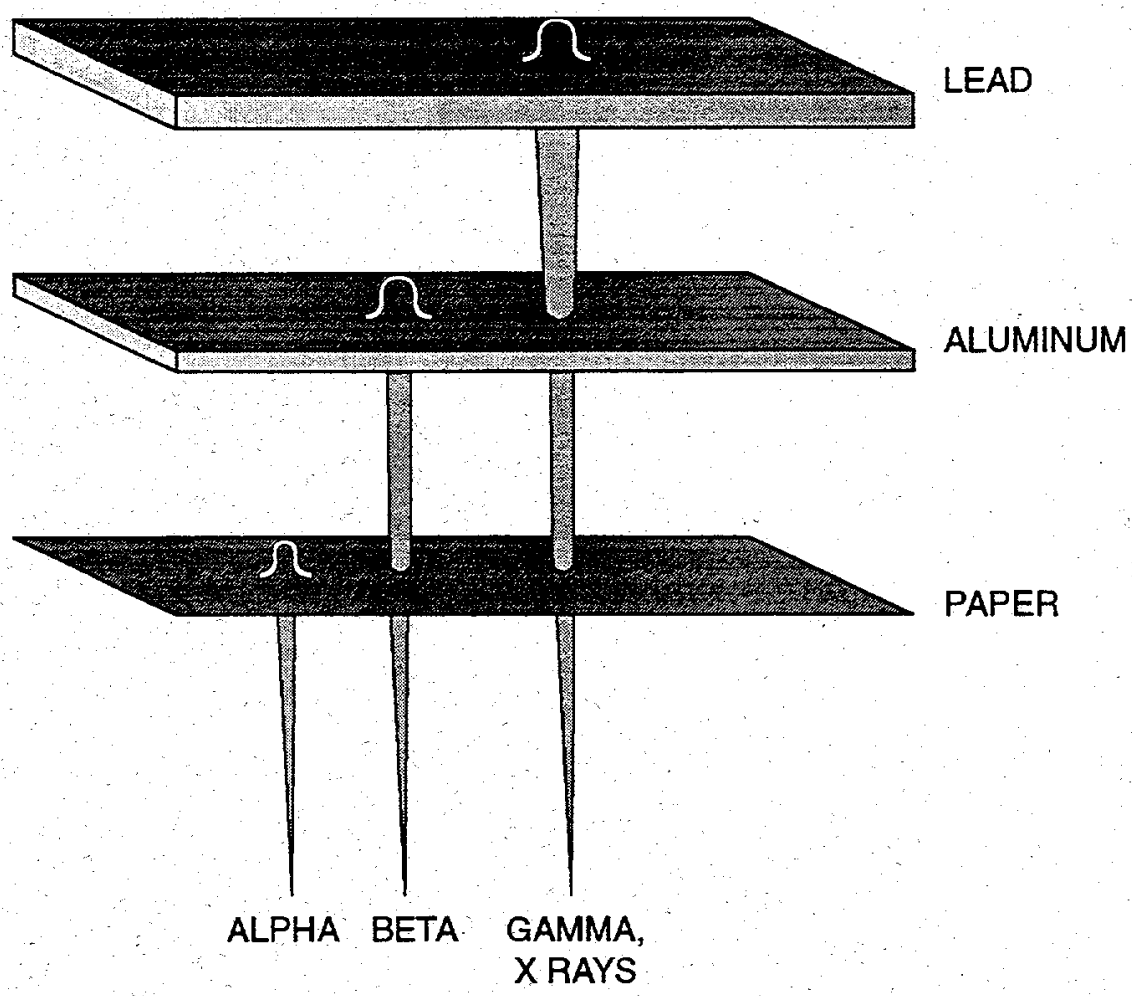

Fig. A.2. Penetrating power of radiation. 


\section{SOURCES OF RADIATION}

Radiation is everywhere. Most occurs naturally, but a small percentage is human made. Naturally occurring radiation is known as background radiation.

\section{Background Radiation}

Many materials are naturally radioactive. In fact, this naturally occurring radiation is the major source of radiation in the environment. Though people have little control over the amount of background radiation to which they are exposed, this exposure must be put into perspective. Background radiation remains relatively constant over time; background radiation present in the environment today is much the same as it was hundreds of years ago.

Sources of background radiation include uranium in the earth, radon in the air, and potassium in food. Background radiation is categorized as cosmic, terrestrial, or internal, depending on its origin.

\section{Cosmic Radiation}

Energetically charged particles from outer space continuously hit the earth's atmosphere. These particles and the secondary particles and photons they create are called cosmic radiation. Because the atmosphere provides some shielding against cosmic radiation, the intensity of this radiation increases with altitude above sea level. In other words, a person in Denver, Colorado, is exposed to more cosmic radiation than a person in Death Valley, California.

\section{Terrestrial Radiation}

Terrestrial radiation refers to radiation emitted from radioactive materials in the earth's rocks, soils, and minerals. Radon $(\mathrm{Rn})$; radon progeny, the relatively short-lived decay products of radium-235 $\left({ }^{235} \mathrm{Ra}\right)$; potassium $\left({ }^{40} \mathrm{~K}\right)$; isotopes of thorium (Th); and isotopes of uranium $(\mathrm{U})$ are the elements responsible for most terrestrial radiation.

\section{Internal Radiation}

Radioactive material in the environment enters the body through the air people breathe and the food they eat; it also can enter through an open wound. Natural radionuclides in the body include isotopes of uranium, thorium, radium, radon, polonium, bismuth, and lead in the ${ }^{238} \mathrm{U}$ and ${ }^{232} \mathrm{Th}$ decay series. In addition, the body contains isotopes of potassium $\left({ }^{40} \mathrm{~K}\right)$, rubidium $\left({ }^{87} \mathrm{Rb}\right)$, and carbon $\left({ }^{14} \mathrm{C}\right)$.

\section{Human-Made Radiation}

In addition to background radiation, there are human-made sources of radiation to which most people are exposed. Examples include consumer products, medical sources, and fallout from atmospheric atomic bomb tests. (Atmospheric testing of atomic weapons has been suspended.) Also, about one-half of $1 \%$ of the U.S. population performs work in which radiation in some form is present. 


\section{Consumer Products}

Some consumer products are sources of radiation. In some of these products, such as smoke detectors and airport $X$-ray baggage inspection systems, radiation is essential to the performance of the device. In other products, such as televisions and tobacco products, the radiation occurs incidentally to the product function.

\section{Medical Sources}

Radiation is an important tool of diagnostic medicine and treatment, and, in this use, is the main source of exposure to human-made radiation. Exposure is deliberate and directly beneficial to the patients exposed. Generally, medical exposures from diagnostic or therapeutic $X$ rays result from beams directed to specific areas of the body. Thus, all body organs generally are not irradiated uniformly. Radiation and radioactive materials are also used in a wide variety of pharmaceuticals and in the preparation of medical instruments, including the sterilization of heat-sensitive products such as plastic heart valves. Nuclear medicine examinations and treatment involve the internal administration of radioactive compounds, or radiopharmaceuticals, by injection, inhalation, consumption, or insertion. Even then, radionuclides are not distributed uniformly throughout the body.

\section{Other Sources}

Other sources of radiation include fallout from atmospheric atomic bomb tests; emissions of radioactive materials from nuclear facilities such as uranium mines, fuel processing plants, and nuclear power plants; emissions from mineral extraction facilities; and transportation of radioactive materials.

\section{PATHWAYS OF RADIATION}

Radiation and radioactive material in the environment can reach people through many routes. Potential routes for radiation are referred to as pathways. For example, radioactive material in the air could fall on a pasture. The grass could then be eaten by cows, and the radioactive material on the grass would show up in the cow's milk. People drinking the milk would thus be exposed to this radiation. Or, people could simply inhale the radioactive material in the air. The same events could occur with radioactive material in water. Fish living in the water would be exposed; people eating the fish would then be exposed to the radiation in the fish. Or, people swimming in the water would be exposed (see Figure A.3).

\section{MEASURING RADIATION}

To determine the possible effects of radiation on the environment and the health of people, the radiation must be measured. More precisely, its potential to cause damage must be determined.

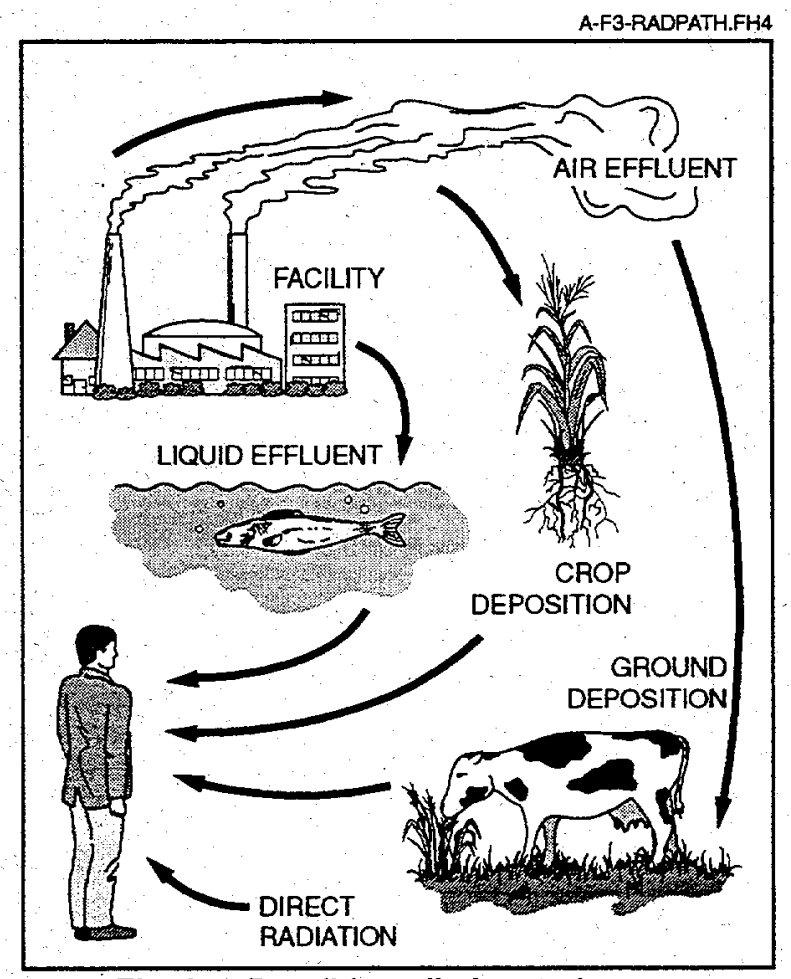

Fig. A.3. Possible radiation pathways. 


\section{Activity}

When measuring the amount of radiation in the environment, what is actually being measured is the rate of radioactive decay, or activity. The rate of decay varies widely among the various radioisotopes. For that reason, $1 \mathrm{~g}$ of a radioactive substance may contain the same amount of activity as several tons of another material. This activity is expressed in a unit of measure known as a curie (Ci). More specifically, $1 \mathrm{Ci}=$ $3.7 \mathrm{E}+10(37,000,000,000)$ atom disintegrations per second (dps). In the international system of units, $1 \mathrm{dps}=$ 1 becquerel $(\mathrm{Bq})$.

\section{Absorbed Dose}

The total amount of energy absorbed per unit mass as a result of exposure to radiation is expressed in a unit of measure known as a rad. In the international system of units, 100 rad equals 1 gray (Gy). However, in terms of human health, it is the effect of the absorbed energy that is important, not the actual amount.

\section{Dose Equivalent}

The measure of potential biological damage caused by exposure to and subsequent absorption of radiation is expressed in a unit of measure known as a rem. One rem of any type of radiation has the same total damaging effect. Because a rem represents a fairly large dose, dose is expressed as a millirem (mrem), or $1 / 1000$ of a rem. In the international system of units, 100 rem equals 1 sievert $(\mathrm{Sv}) ; 100$ mrem equals 1 millisievert (mSv).

\section{DOSE}

Many terms are used to report dose. Several factors are taken into account, including the amount of radiation absorbed, the organ absorbing the radiation, and the effect of the radiation over a 50-year period. The term "dose," in this report, includes the committed effective dose equivalent (CEDE) and the EDE attributable to penetrating radiation from sources external to the body.

Determining dose is an involved process using complex mathematical equations based on several factors, including the type of radiation, the rate of exposure, weather conditions, and typical diet. Basically, radiant energy is generated from radioactive decay, or activity. People absorb some of the energy to which they are exposed. This absorbed energy is calculated as part of an individual's dose. Whether radiation is natural or human made, its effects on people are the same.

\section{Comparison of Dose Levels}

A scale of dose levels is presented in Table A.1. Included is an example of the type of exposure that may cause such a dose or the special significance of such a dose. This information is intended to help the reader become familiar with the type of doses individuals may receive. 
Table A.1. Comparison and description of various dose levels.

Dose level

Description

$1 \mathrm{mrem}(0.01 \mathrm{mSv})$

2.5 mrem $(0.025 \mathrm{mSv})$

$10 \mathrm{mrem}(0.10 \mathrm{mSv})$

$46 \mathrm{mrem}(0.46 \mathrm{mSv})$

$50 \mathrm{mrem}(0.50 \mathrm{mSv})$

$66 \mathrm{mrem}(0.66 \mathrm{mSv})$

$100 \mathrm{mrem}(1.00 \mathrm{mSv})$

$110 \mathrm{mrem}(1.10 \mathrm{mSv})$

244 mrem $(2.44 \cdot \mathrm{mSv})$

300 mrem $(3.00 \mathrm{mSv})$

$1-5 \mathrm{rem}(0.01-0.05 \mathrm{~Sv})$

$5 \mathrm{rem}(0.05 \mathrm{~Sv})$

$10 \mathrm{rem}(0.10 \mathrm{~Sv})$

$25 \mathrm{rem}(0.25 \mathrm{~Sv})$

$75 \mathrm{rem}(0.75 \mathrm{~Sv})$

$50-600$ rem $(0.50-6.00 \mathrm{~Sv})$
Approximate daily dose from natural background radiation, including radon.

Cosmic dose to a person on a one-way airplane flight from New York to Los Angeles

Annual exposure limit, set by the USEPA, for exposures from airborne emissions from operations of nuclear fuel cycle facilities, including power plants and uranium mines and mills

Estimate of the largest dose any off-site person could have received from the March 28, 1979, Three Mile Island nuclear power plant accident

Average yearly dose from cosmic radiation received by people in the Portsmouth area

Average yearly dose to people in the United States from human-made sources

Annual limit of dose from all U.S. Department of Energy facilities to a member of the public who is not a radiation worker

Average occupational dose received by U.S. commercial radiation workers in 1980

Average dose from an upper gastrointestinal diagnostic X-ray series

Average yearly dose to people in the United States from all sources of natural background radiation

USEPA protective action guidelines state that public officials should take emergency action when the dose to a member of the public from a nuclear accident will likely reach this range

Annual limit for occupational exposure of radiation workers set by the U.S. Nuclear Regulatory Commission and the U.S. Department of Energy

The BEIR V report estimated that an acute dose at this level would result in a lifetime excess risk of death from cancer, caused by the radiation, of $0.8 \%$ (BEIR 1990)

USEPA guideline for voluntary maximum dose to emergency workers for non-lifesaving work during an emergency

USEPA guideline for maximum dose to emergency workers volunteering for lifesaving work

Doses in this range received over a short period of time will produce radiation sickness in varying degrees. At the lower end of this range, people are expected to recover completely, given proper medical attention. At the top of this range most people would die within 60 days.

Adapted from Savannah River Site Environmental Report for 1993, Summary Pamphlet, WSRC-TR-94-076, Westinghouse Savannah River Company, 1994. 


\section{Dose from Cosmic Radiation}

The average annual dose received by residents of the United States from cosmic radiation is about 27 mrem (0.27 mSv) (NCRP 1987). The average annual dose from cosmic radiation received by residents in the Portsmouth area is about $50 \mathrm{mrem}(0.50 \mathrm{mSv})$.

\section{Dose from Terrestrial Radiation}

The average annual dose received from terrestrial gamma radiation is about $28 \mathrm{mrem}(0.28 \mathrm{mSv})$ in the United States. This dose varies geographically across the country (NCRP 1987); typical reported values are $16 \mathrm{mrem}(0.16 \mathrm{mSv})$ at the Atlantic and Gulf coastal plains and $63 \mathrm{mrem}(0.63 \mathrm{mSv})$ at the eastern slopes of the Rocky Mountains.

\section{Dose from Internal Radiation}

Short-lived decay products of radon are the major contributors to the annual dose equivalent for internal radionuclides (mostly ${ }^{222} \mathrm{Rn}$ ). They contribute an average dose of about $200 \mathrm{mrem}(2.00 \mathrm{mSv})$ per year. This dose estimate is based on an average radon concentration of about $1 \mathrm{pCi} / \mathrm{L}(0.037 \mathrm{~Bq} / \mathrm{L})(\mathrm{NCRP}$ 1987).

The average dose from other internal radionuclides is about 39 mrem $(0.39 \mathrm{mSv})$ per year, most of which can be attributed to the naturally occurring isotope of potassium, ${ }^{40} \mathrm{~K}$. The concentration of radioactive potassium in human tissues is similar in all parts of the world (NCRP 1987).

\section{Dose from Consumer Products}

The U.S. average annual dose received by an individual from consumer products is about $10 \mathrm{mrem}$ (0.10 mSv) (NCRP 1987).

\section{Dose from Medical Sources}

Nuclear medicine examinations, which involve the internal administration of radiopharmaceuticals, generally account for the largest portion of the dose received from human-made sources. However, the radionuclides used in specific tests are not distributed uniformly throughout the body. In these cases, comparisons are made using the concept of EDE, which relates exposure of organs or body parts to one effective whole-body dose. The average annual EDE from medical examinations is $53 \mathrm{mrem}(0.53 \mathrm{mSv})$, including 39 mrem $(0.39 \mathrm{mSv})$ for diagnostic X-rays and $14 \mathrm{mrem}(0.14 \mathrm{mSv})$ for nuclear medicine procedures (NCRP 1989). The actual doses received by individuals who complete such medical exams are much higher than these values, but not everyone receives such exams each year (NCRP 1989).

\section{Dose from Other Sources}

Small doses received by individuals occur as a result of radioactive fallout from atmospheric atomic bomb tests, emissions of radioactive materials from nuclear facilities, emissions from certain mineral extraction facilities, and transportation of radioactive materials. The combination of these sources contributes less than $1 \mathrm{mrem}(0.01 \mathrm{mSv})$ per year to the average dose to an individual (NCRP 1987). 
A comprehensive U.S. Environmental protection Agency (USEPA) report of 1984 projected the average occupational dose to monitored radiation workers in medicine, industry, the nuclear fuel cycle, government, and miscellaneous industries to be $105 \mathrm{mrem}(1.05 \mathrm{mSv})$ per year for 1985 , down slightly from 110 mrem (1.10 mSv) per year in 1980 (Kumazawa et al. 1984). 


\section{Appendix B: Environmental Permits}

Table B.1. DOE/PORTS environmental permits.

\begin{tabular}{|c|c|c|c|c|}
\hline Permitted unit & Source No. & Issue Date & $\begin{array}{l}\text { Expiration } \\
\text { Date }\end{array}$ & Status \\
\hline \multicolumn{5}{|c|}{ Air permits } \\
\hline $\begin{array}{l}X-735 \text { Landfill roads and } \\
\text { parking areas }\end{array}$ & $\mathrm{F} 002$ & $2 / 8 / 93$ & $2 / 8 / 96$ & \multirow{3}{*}{$\begin{array}{l}\text { Renewal PTO applied for. } \\
\text { Awaiting action by Ohio EPA. } \\
\text { Renewal PTO applied for. } \\
\text { Awaiting action by Ohio EPA } \\
\text { Appealed }\end{array}$} \\
\hline $\begin{array}{l}X-735 \text { Refuse and asbestos } \\
\text { handling }\end{array}$ & F001 & $2 / 8 / 93$ & $2 / 8 / 96$ & \\
\hline Mobile drum dumper & $\mathrm{P} 026$ & $11 / 3 / 95$ & $11 / 3 / 98$ & \\
\hline Chrome sludge repacking & $\mathrm{P} 025$ & $11 / 3 / 95$ & $11 / 3 / 98$ & Appealed \\
\hline$X-326$ Seal exhaust-Area 5 & P010 & $11 / 3 / 95$ & $11 / 3 / 98$ & Appealed (transfer to USEC) \\
\hline $\begin{array}{l}\text { X-7725 Hydraulic drum } \\
\text { dumper }\end{array}$ & $\mathrm{P} 024$ & $11 / 17 / 95$ & $11 / 17 / 98$ & Appealed \\
\hline $\begin{array}{l}X-624 \text { Groundwater } \\
\text { treatment facility }\end{array}$ & P019 & $11 / 17 / 95$ & $11 / 17 / 98$ & Appealed (resend PTO) \\
\hline $\begin{array}{l}X-345 \text { Sampling glovebox } \\
\text { vent }\end{array}$ & P009 & $11 / 17 / 95$ & $11 / 17 / 98$ & Appealed \\
\hline $\begin{array}{l}\text { X-345 Laboratory fume } \\
\text { hood }\end{array}$ & P006 & $11 / 17 / 95$ & $11 / 17 / 98$ & Appealed \\
\hline $\begin{array}{l}X-345 \text { High-Assay } \\
\text { sampling area }\end{array}$ & P008 & $11 / 17 / 95$ & $11 / 17 / 98$ & Appealed \\
\hline 1446 Glovebox & $\mathrm{P} 007$ & $11 / 17 / 95$ & $11 / 17 / 98$ & Appealed \\
\hline $\begin{array}{l}X-735 \text { Landfill cap \& } \\
\text { venting system }\end{array}$ & $\mathrm{P} 023$ & $5 / 26 / 95$ & $5 / 26 / 98$ & Active \\
\hline $\mathrm{X}-326$ Glovebox & $\mathrm{P} 022$ & $5 / 5 / 95$ & $5 / 5 / 98$ & Active \\
\hline \multicolumn{5}{|c|}{ Wastewater permits } \\
\hline NPDES (DOE) & & $9 / 1 / 95$ & $9 / 1 / 00$ & Active \\
\hline \multicolumn{5}{|c|}{ Hazardous waste permits } \\
\hline RCRA, Part B & & $8 / 21 / 95$ & $8 / 21 / 00$ & Active \\
\hline
\end{tabular}




\section{Appendix C: Chemical Release Data}

Table C.1. DOE/PORTS toxic chemical release inventory for 1995.

\begin{tabular}{|c|c|c|c|c|}
\hline Chemical & Type of release & $\begin{array}{c}\text { Release } \\
\text { quantity (lb) }\end{array}$ & Release sources & Basis of estimate \\
\hline Ethylene Glycol & Air: fugitive & 3 & Cooling System & Mass balance \\
\hline Fluorine & Air: stack & 1300 & $\begin{array}{l}\text { HEU Purge cascade } \\
\text { operations }\end{array}$ & Mass balance \\
\hline Hydrogen fluoride & Air: stack & 570 & $\begin{array}{l}\text { HEU Purge cascade } \\
\text { operations }\end{array}$ & Mass balance \\
\hline Zinc & $\begin{array}{l}\text { Water: } \\
\text { West drainage } \\
\text { ditch } \\
\text { Southwest drainage } \\
\text { ditch } \\
\text { GCEP pond surface } \\
\text { impoundment }\end{array}$ & $\begin{array}{l}53 \\
53 \\
47\end{array}$ & $\begin{array}{l}\text { Water treatment } \\
\text { Water treatment } \\
\text { Water treatment }\end{array}$ & $\begin{array}{l}\text { Monitoring data } \\
\text { Monitoring data } \\
\text { Mass balance }\end{array}$ \\
\hline
\end{tabular}




\section{Appendix D: Radionuclide and Chemical Nomenclature}

Table D.1. Nomenclature and half-life for radionuclides.

\begin{tabular}{lll}
\hline Radionuclide & Symbol & Half-life \\
\hline Bismuth-210 & ${ }^{110} \mathrm{Bi}$ & 5.01 days \\
Bismuth-214 & ${ }^{214} \mathrm{Bi}$ & 19.7 minutes \\
Lead-206 & ${ }^{206} \mathrm{~Pb}$ & Stable \\
\hline Lead-210 & ${ }^{10} \mathrm{~Pb}$ & 21 years \\
Lead-214 & ${ }^{214} \mathrm{~Pb}$ & 26.8 minutes \\
Polonium-210 & ${ }^{210} \mathrm{Po}$ & 138.9 days \\
Polonium-214 & ${ }^{114} \mathrm{Po}$ & 164 microseconds \\
Polonium-218 & ${ }^{18} \mathrm{Po}$ & 3.05 minutes \\
Potassium-40 & ${ }^{40} \mathrm{~K}$ & $1,260,000,000$ years \\
Protactinium-234m & ${ }^{234 \mathrm{~m}} \mathrm{~Pa}$ & 1.17 minutes \\
Radium-226 & ${ }^{226} \mathrm{Ra}$ & 1,602 years \\
Radon-222 & ${ }^{222} \mathrm{Rn}$ & 3.821 days \\
Technetium-99 & ${ }^{99} \mathrm{Tc}$ & 212,000 years \\
Thorium-230 & ${ }^{230} \mathrm{Th}$ & 80,000 years \\
Thorium-231 & ${ }^{231} \mathrm{Th}$ & 25,5 hours \\
Thorium-234 & ${ }^{234} \mathrm{Th}$ & 24.1 days \\
Uranium-234 & ${ }^{234} \mathrm{U}$ & 247,000 years \\
Uranium-235 & ${ }^{235} \mathrm{U}$ & $710,000,000$ years \\
Uranium-236 & ${ }^{236} \mathrm{U}$ & $23,900,000$ years \\
Uranium-238 & ${ }^{238} \mathrm{U}$ & $4,510,000,000$ years \\
\hline & & \\
\hline
\end{tabular}


Table D.2. Nomenclature for elements and chemical constituents.

\begin{tabular}{|c|c|}
\hline Constituent & Symbol \\
\hline Aluminum & $\mathrm{Al}$ \\
\hline Ammonia & $\mathrm{NH}_{3}$ \\
\hline Antimony & $\mathrm{Sb}$ \\
\hline Arsenic & As \\
\hline Barium & $\mathrm{Ba}$ \\
\hline Beryllium & $\mathrm{Be}$ \\
\hline Cadmium & $\mathrm{Cd}$ \\
\hline Calcium & $\mathrm{Ca}$ \\
\hline Calcium carbonate & $\mathrm{CaCO}_{3}$ \\
\hline Carbon & $\mathrm{C}$ \\
\hline Chlorine & $\mathrm{Cl}$ \\
\hline Chromium & $\mathrm{Cr}$ \\
\hline Chromium, hexavalent & $\mathrm{Cr}_{6+}$ \\
\hline Cobalt & $\mathrm{Co}$ \\
\hline Copper & $\mathrm{Cu}$ \\
\hline Fluorine & $F$ \\
\hline Hydrogen fluoride & $\mathrm{HF}$ \\
\hline Iron & $\mathrm{Fe}$ \\
\hline Lead & $\mathrm{Pb}$ \\
\hline Lithium & $\mathrm{Li}$ \\
\hline Magnesium & $\mathrm{Mg}$ \\
\hline Manganese & $\mathrm{Mn}$ \\
\hline Mercury & $\mathrm{Hg}$ \\
\hline Nickel & $\mathrm{Ni}$ \\
\hline Nitrogen & $\mathbf{N}$ \\
\hline Nitrate & $\mathrm{NO}_{3}$ \\
\hline Nitrite & $\mathrm{NO}_{2}$ \\
\hline Oxygen & $\mathrm{O}$ \\
\hline Ozone & $\mathrm{O}_{3}$ \\
\hline Phosphorus & $\mathrm{P}$ \\
\hline Phosphate & $\mathrm{PO}_{4}$ \\
\hline Potassium & $\mathrm{K}$ \\
\hline Radium & $\mathrm{Ra}$ \\
\hline Radon & $\mathrm{Rn}$ \\
\hline Selenium & $\mathrm{Se}$ \\
\hline Silver & $\mathrm{Ag}$ \\
\hline Sodium & $\mathrm{Na}$. \\
\hline Sulfate & $\mathrm{SO}_{4}$ \\
\hline Sulfur dioxide & $\mathrm{SO}_{2}$ \\
\hline Thorium & Th \\
\hline Uranium & $\mathrm{U}$ \\
\hline Zinc & $\mathrm{Zn}$ \\
\hline
\end{tabular}




\section{References}

American Nuclear Society (ANS). 1986. Glossary of Terms in Nuclear Science and Technology, American Nuclear Society.

American National Standards Institute (ANSI). 1975. Performance Testing and Procedural Specificationsfor Thermoluminescent Dosimetry (Environmental Applications), New York, N.Y.

Baker, D. A., and J. K. Soldat. 1993. "Methods for Estimating Doses to Organisms from Radioactive Materials Released into the Aquatic Environment," PNL-8150, Pacific Northwest Laboratories, Richland, Wash.

Beres, D. A. 1990. The Clean Air Act Assessment Package-1988 (CAP-88): A Dose and Risk Assessment Methodology for Radionuclide Emissions to Air, SC\&A, Inc., McLean, Va.

BEIR. 1990. Health Effects of Exposure to Low Levels of lonizing Radiation, Committee on the Biological Effects of Ionizing Radiations (BEIR V), National Research Council, National Academy of Sciences, National Academy Press, Washington, D.C.

Geraghty and Miller. 1989. Groundwater Quality Assessment of Four RCRA Units. Dublin, Ohio.

International Commission on Radiological Protection (ICRP). 1977. Annals of the ICRP I,

ICRP Publication 26, Pergamion, Oxford, N.Y.

1978. Publication 30, Pergamon, Oxford, N.Y.

Kumazawa S., et al. 1984. Occupational Exposure to lonizing Radiation in the United States: A Comprehensive Review for the Year 1980 and a Summary of Trends for the Years 1960-1985, EPA/520/1-8-005, U.S. Government Printing Office, Washington, D.C.

Martin Marietta Energy Systems (MMES). March 31, 1994. Environmental Monitoring Plan for the Portsmouth Gaseous Diffusion Plant, POEF-EW-1 1 .

McGraw-Hill. 1989. McGraw-Hill Dictionary of Scientific and Technical Terms, 4th ed., McGraw-Hill, Inc., New York.

National Council on Radiation Protection (NCRP). 1987. Ionizing Radiation Exposure of the Population of the United States, NCRP Report No. 93, National Council on Radiation Protection and Measurements, Washington, D.C.

1989. Exposure of the U.S. Population from Diagnostic Medical Radiation, NCRP Report No.

100, National Council on Radiation Protection and Measurements, Bethesda, Md.

Nuclear Regulatory Commission. 1969. National Register of Historic Places, Washington, D.C.

U.S. Environmental Protection Agency (USEPA). September 1989a. RCRA Groundwater Monitoring

Technical Enforcement Guidance Document, OSWER-9950.1, USEPA.

1989b. Risk Assessment Guidance for Superfund: Human Health Evaluation Manual, Part A (Interim

Final), Washington, D.C.

1991. Integrated Risk Information System (IRIS) (data base), Washington, D.C. 


\section{Glossary}

absorption-The process by which the number and energy of particles or photons entering a body of matter is reduced by interaction with the matter.

activity - See radioactivity.

aliquot - The quantity of sample being used for analysis that is representative of a larger quantity (e.g., 5 aliquots of 15 in the sample).

alpha particle $A$ positively charged particle emitted from the nucleus of an atom having the same charge and mass as that of a helium nucleus (two protons and two neutrons).

ambient air - The atmosphere around people, plants, and structures.

analytical detection limit-The lowest reasonably accurate concentration of an analyte that can be detected; this value varies depending on the method, instrument, and dilution used.

analyte-A constituent or parameter being analyzed.

aquifer-A saturated, permeable geologic unit that can transmit significant quantities of water under ordinary hydraulic gradients.

aquitard-A geologic unit that inhibits the flow of water.

ash-Inorganic residue remaining after ignition of combustible substances.

assimilate-To take up or absorb.

atom-Smallest particle of an element capable of entering into a chemical reaction.

beta particle-A negatively charged particle emitted from the nucleus of an atom. It has a mass and charge equal to those of an electron.

biota - The animal and plant life of a particular region considered as a total ecological entity.

CERCLA-reportable release-A release to the environment that exceeds reportable quantities as defined by CERCLA (Comprehensive Environmental Response, Compensation, and Liability Act).

chain of custody-A form that documents sample collection, transport, analysis, and disposal.

$\mathrm{Ci}$-See curie.

closure-Control of a hazardous waste management facility under Resource Conservation and Recovery Act requirements. 
compliance-Fulfillment of applicable requirements of a plan or schedule ordered or approved by government authority.

concentration - The amount of a substance contained in a unit volume or mass of a sample.

conductivity - A measure of water's capacity to convey an electric current. This property is related to the total concentration of the ionized substances in water and the temperature at which the measurement is made.

confluence-The point at which two or more streams meet; the point where a tributary joins the main stream.

contamination-Deposition of unwanted material on the surfaces of structures, areas, objects, or personnel.

control limits-A statistical tool used to define the bounds of virtually all values produced by a system in statistical control.

cosmic radiation-Ionizing radiation with very high energies that originates outside the earth's atmosphere. Cosmic radiation is one contributor to natural background radiation.

curie (Ci) - A unit of radioactivity. One curie is defined as $3.7 \times 10^{10}$ (37 billion) disintegrations per second. Several fractions and multiples of the curie are commonly used:

kilocurie $(\mathbf{k C i})-10^{3} \mathrm{Ci}$, one thousand curies; $3.7 \times 10^{13}$ disintegrations per second. millicurie $(\mathrm{mCi})-10^{-3} \mathrm{Ci}$, one-thousandth of a curie; $3.7 \times 10^{7}$ disintegrations per second. microcurie $(\mu \mathrm{Ci})-10^{-6} \mathrm{Ci}$, one-millionth of a curie; $3.7 \times 10^{4}$ disintegrations per second. picocurie $(\mathbf{p C i})-10^{-12} \mathrm{Ci}$, one-trillionth of a curie; 0.037 disintegrations per second.

daughter-A nuclide formed by the radioactive decay of a parent nuclide.

DCG-See derived concentration guide.

decay, radioactive - The spontaneous transformation of one radionuclide into a different radioactive or nonradioactive nuclide or into a different energy state of the same radionuclide .

decontamination and decommissioning-See Environmental Restoration.

dense nonaqueous phase liquid (DNAPL) - The liquid phase of chlorinated organic solvents. These liquids are denser than water and include commonly used industrial compounds such as tetrachloroethene and trichloroethene.

derived concentration guide (DCG) - The concentration of a radionuclide in air or water that under conditions of continuous exposure for one year by one exposure mode (i.e., ingestion of water, submersion in air, or inhalation) would result in either an effective dose equivalent of $0.1 \mathrm{rem}$ ( $1 \mathrm{mSv}$ ) or a dose equivalent of 5 rem $(50 \mathrm{mSv})$ to any tissue, including skin and the lens of the eye. The guidelines for radionuclides in air and water are given in DOE Order 5400.5, Radiation Protection of the Public and the Environment.

detector-Material or device (instrument) that is sensitive to radiation and can produce a signal suitable for measurement or analysis. 
disintegration, nuclear-A spontaneous nuclear transformation (radioactivity) characterized by the emission of energy and/or mass from the nucleus of an atom.

DNAPL - See dense nonaqueous phase liquid.

dose- The energy imparted to matter by ionizing radiation. The unit of absorbed dose is the rad, equal to 0.01 joules per kilogram in any medium.

absorbed dose - The quantity of radiation energy absorbed by an organ divided by the organ's mass. Absorbed dose is expressed in units of rad (or gray) ( $1 \mathrm{rad}=0.01 \mathrm{~Gy})$.

dose equivalent - The product of the absorbed dose (rad) in tissue and a quality factor. Dose equivalent is expressed in units of rem (or sievert) $(1 \mathrm{rem}=0.01 \mathrm{~Sv}$ ).

committed dose equivalent-The calculated total dose equivalent to a tissue or organ over a 50 -year period after known intake of a radionuclide into the body. Contributions from external dose are not included. Committed dose equivalent is expressed in units of rem (or sievert).

committed effective dose equivalent - The sum of the committed dose equivalents to various tissues in the body, each multiplied by the appropriate weighting factor. Committed effective dose equivalent is expressed in units of rem (or sievert).

effective dose equivalent - The sum of the dose equivalents received by all organs or tissues of the body after each one has been multiplied by an appropriate weighting factor. The effective dose equivalent includes the committed effective dose equivalent from internal deposition of radionuclides and the effective dose equivalent attributable to sources external to the body.

collective dose equivalent/collective effective dose equivalent - The sums of the dose equivalents or effective dose equivalents of all individuals in an exposed population within a 50 -mile $(80-\mathrm{km})$ radius expressed in units of person-rem (or person-sievert). When the collective dose equivalent of interest is for a specific organ, the units would be organ-rem (or organ-sievert). The 50-mile distance is measured from a point located centrally with respect to major facilities or DOE program activities.

dosimeter-A portable detection device for measuring the total accumulated exposure to ionizing radiation.

dosimetry - The theory and application of principles and techniques involved in the measurement and recording of radiation doses. Its practical aspect is concerned with using various types of radiation instruments to make measurements.

downgradient - In the direction of decreasing hydrostatic head.

downgradient well - $\mathrm{A}$ well that is installed hydraulically downgradient of a site and that may be capable of detecting migration of contaminants from a site.

drinking water standards (DWS) - Federal primary drinking water standards, both proposed and final, as set forth by the U.S. Environmental Protection Agency.

DWS--See drinking water standards.

effluent - A liquid or gaseous waste discharge to the environment. 
effluent monitoring - The collection and analysis of samples or measurements of liquid and gaseous effluents for purposes of characterizing and quantifying the release of contaminants, assessing radiation exposures of members of the public, and demonstrating compliance with applicable standards.

Environmental Restoration-A DOE program that directs the assessment and cleanup of its sites (remediation) and facilities (decontamination and decommissioning) contaminated with waste as a result of nuclearrelated activities

exposure (radiation)-The incidence of radiation on living or inanimate material by accident or intent. Background exposure is the exposure to natural background ionizing radiation. Occupational exposure is that exposure to ionizing radiation that takes place at a person's workplace. Population exposure is the exposure to the total number of persons who inhabit an area.

external radiation - Exposure to ionizing radiation when the radiation source is located outside the body.

fauna-The population of animals at a given area, environment, formation, or time span.

fecal coliform-The coliform group comprises all of the aerobic, non-spore-forming, rod-shaped bacteria. The test determines the presence or absence of coliform organisms.

flora-The population of plants at a given area, environment, formation, or time span.

formation-A mappable unit of consolidated or unconsolidated geologic material of a characteristic lithology or assemblage of lithologies.

gamma ray-High-energy, short-wavelength electromagnetic radiation emitted from the nucleus of an excited atom. Gamma rays are identical to X-rays except for the source of the emission.

gamma spectrometry - A system consisting of a detector, associated electronics, and a multichannel analyzer that is used to analyze samples for gamma-emitting radionuclides.

Gaussian puff/plume model-A computer-simulated atmospheric dispersion of a release using a Gaussian (normal) statistical distribution to determine concentrations in air.

Geiger-Mueller (GM) counter-A highly sensitive, gas-filled radiation detector that operates at voltages sufficiently high to produce ionization. The counter is used primarily in the detection of gamma radiation and beta emission. It is named for Hans Geiger and W. Mueller, who invented it in 1928.

grab sample-A sample collected instantaneously with a glass or plastic bottle placed below the water surface to collect surface water samples (also called dip samples).

groundwater, unconfined-Groundwater exposed to the unsaturated zone.

half-life, radiological-The time required for half of a given number of atoms of a specific radionuclide to decay. Each nuclide has a unique half-life.

hydrology - The science dealing with the properties, distribution, and circulation of natural water systems.

\section{G-4 Glossary}


hydrogeology - Hydraulic aspects of site geology.

in situ-In its original place, field measurements taken without removing the sample from its origin; remediation performed while the contaminated media (e.g., groundwater) remains below the surface.

interim remedial measure (IRM)--Cleanup activities initiated after it has been determined that contamination or waste disposal practices pose an immediate threat to human health and/or the environment. These measures are implemented until a more permanent solution can be made.

internal dose factor - A factor used to convert intakes of radionuclides to dose equivalents.

internal radiation-Occurs when natural radionuclides enter the body by ingestion of foods, milk, or water or by inhalation. Radon is the major contributor to the annual dose equivalent for internal radionuclides.

ion-An atom or compound that carries an electrical charge.

irradiation-Exposure to radiation.

isotopes - Forms of an element having the same number of protons but differing numbers of neutrons in their nuclei.

long-lived isotope - A radionuclide that decays at such a slow rate that a quantity of it will exist for an extended period (half-life is greater than three years).

short-lived isotope - A radionuclide that decays so rapidly that a given quantity is transformed almost completely into decay products within a short period (half-life is two days or less).

LLD-See lower limit of detection.

lower limit of detection (LLD) - The smallest concentration or amount of analyte that can be reliably detected in a sample at a $95 \%$ confidence level.

maximally exposed individual - A hypothetical individual who remains in an uncontrolled area and would, when all potential routes of exposure from a facility's operations are considered, receive the greatest possible dose equivalent.

migration-The transfer or movement of a material through air, soil, or groundwater.

milliroentgen ( $\mathbf{m R}$ ) - A measure of X-ray or gamma radiation. The unit is one-thousandth of a roentgen.

minimum detectable concentration-The smallest amount or concentration of a radionuclide that can be distinguished in a sample by a given measurement system at a preselected counting time and at given confidence level.

monitoring-Process whereby the quantity and quality of factors that can affect the environment or human health are measured periodically to regulate and control potential impacts.

mrem-The dose equivalent that is one-thousandth of a rem. 
natural radiation-Radiation from cosmic and other naturally occurring radionuclide (such as radon) sources in the environment.

nuclide - An atom specified by its atomic weight, atomic number, and energy state. A radionuclide is a radioactive nuclide.

outcrop-A place where groundwater is discharged to the surface. Springs, swamps, and beds of streams and rivers are the outcrops of the water table.

outfall-The point of conveyance (e.g., drain or pipe) of wastewater or other effluents into a ditch, pond, or river.

part per billion (ppb)-A unit measure of concentration equivalent to the weight/volume ratio expressed as $\mathrm{g} / \mathrm{L}$ or $\mathrm{ng} / \mathrm{mL}$.

part per million (ppm) - A unit measure of concentration equivalent to the weight/volume ratio expressed as $\mathrm{mg} / \mathrm{L}$.

person-rem-Collective dose to a population group. For example, a dose of 1 rem to 10 individuals results in a collective dose of 10 person-rem.

$\mathrm{pH}-\mathrm{A}$ measure of the hydrogen ion concentration in an aqueous solution. Acidic solutions have a pH from 0 to 7 , neutral solutions have a $\mathrm{pH}$ equal to 7 , and basic solutions have a $\mathrm{pH}$ from 7 to 14 .

piezometer-An instrument used to measure the potentiometric surface of the groundwater; also, a well designed for this purpose.

ppb-See part per billion.

ppm-See part per million.

process water - Water used within a system process.

process sewer-Pipe or drain, generally located underground, used to carry off process water or waste matter.

purge-To remove water before sampling, generally by pumping or bailing.

QA--See quality assurance.

QC-See quality control.

quality assurance (QA) - Any action in environmental monitoring to ensure the reliability of monitoring and measurement data:

quality control (QC) - The routine application of procedures within environmental monitoring to obtain the required standards of performance in monitoring and measurement processes.

\section{G-6 Glossary}


quality factor-The factor by which the absorbed dose (rad) is multiplied to obtain a quantity that expresses, on a common scale for all ionizing radiation, the biological damage to exposed persons. A quality factor is used because some types of radiation, such as alpha particles, are more biologically damaging than others.

rad-The unit of absorbed dose deposited in a volume of material.

radiation detection instruments - Devices that detect and record the characteristics of ionizing radiation.

radioactivity - The spontaneous emission of radiation, generally alpha or beta particles or gamma rays, from the nucleus of an unstable isotope.

radioisotopes-Radioactive isotopes.

radionuclide - An unstable nuclide capable of spontaneous transformation into other nuclides by changing its nuclear configuration or energy level. This transformation is accompanied by the emission of photons or particles.

RCRA--See Resource Conservation and Recovery Act.

reference material-A material or substance with one or more properties that is sufficiently well established and used to calibrate an apparatus, to assess a measurement method, or to assign values to materials.

release - Any discharge to the environment. Environment is broadly defined as any water, land, or ambient air.

rem-The unit of dose equivalent (absorbed dose in rads times the radiation quality factor). Dose equivalent is frequently reported in units of millirem (mrem), which is one-thousandth of a rem.

remediation-The correction of a problem. See Environmental Restoration.

Resource Conservation and Recovery Act (RCRA) - Federal legislation that regulates the transport, treatment, and disposal of solid and hazardous wastes.

RFI Program-RCRA Facility Investigation Program; U.S. Environmental Protection Agency-regulated investigation of a solid waste management unit with regard to its potential impact on the environment.

roentgen - A unit of exposure from $X$ rays or gamma rays. One roentgen equals $2.58 \times 10^{-4}$ coulombs per kilogram of air.

routine radioactive release-A planned or scheduled release of radioactivity to the environment.

screen zone-In well construction, the section of a formation that contains the screen, or perforated pipe, that allows water to enter the well.

sidegradient well $\mathrm{A}$ well that intercepts groundwater flowing next to a site; a sidegradient well is located neither upgradient nor downgradient to the monitored site. 
sievert (Sv)-The SI (International System of Units) unit of dose equivalent; I Sv $=100$ rem.

slurry-A suspension of solid particles (sludge) in water.

Solid waste disposal facility (SWDF) - A place for burying unwanted radioactive material to prevent escape of radioactivity. The surrounding water acts as a shield. Such material is placed in watertight, noncorrodible containers so that it cannot leach out and invade underground water.

source--A point or object from which radiation or contamination emanates.

specific conductance - The ability of water to conduct electricity; this ability varies in proportion to the amount of ionized minerals in the water.

stable-Not radioactive or not easily decomposed or otherwise modified chemically.

stack-A vertical pipe or flue designed to exhaust airborne gases and suspended particulate matter.

standard deviation-An indication of the dispersion of a set of results around their average.

storm water runoff-Surface streams that appear after precipitation.

strata-Beds, layers, or zones of rocks.

substrate-The substance, base, surface, or medium in which an organism lives and grows.

surface water-All water on the surface of the earth, as distinguished from groundwater.

suspended solids-Mixture of fine, nonsettling particles of any solid within a liquid or gas.

Sv-See sievert.

SWDF - See solid waste disposal facility.

terrestrial radiation - Ionizing radiation emitted from radioactive materials, primarily potassium- 40 , thorium, and uranium, in the earth's soils, Terrestrial radiation contributes to natural background radiation.

thermoluminescent dosimeter (TLD) -A device used to measure external gamma radiation.

TLD_See thermoluminescent dosimeter.

total activity - The total quantity of radioactive decay particles that are emitted from a sample.

total solids-The sum of total dissolved solids and suspended solids.

total suspended particulates-Refers to the concentration of particulates in suspension in the air irrespective of the nature, source, or size of the particulates. 
t-test-Statistical method used to determine if the means of groups of observations are equal.

turbidity - A measure of the concentration of sediment or suspended particles in solution.

upgradient - In the direction of increasing hydrostatic head.

vadose zone - Soil zone located above the water table.

volatile organic compounds-1,1,1-TCA, perclene, and triclene are common names for trichloroethane, tetrachloroethene, and trichloroethene, respectively. Used in many processes, the levels of these carcinogenic compounds must be kept to a minimum. They are measured by volatile organic analyses content.

watershed-The region draining into a river, river system, or body of water.

wetland-A lowland area, such as a marsh or swamp, inundated or saturated by surface or groundwater sufficiently to support hydrophytic vegetation typically adapted to life in saturated soils.

wind rose-A diagram in which statistical information concerning direction and speed of the wind at a location is summarized. 
POEF-LMES-85

\section{Internal Distribution}
D. Allen
F. J. Anderson
F. Bullock
S. Childers
C.D. Conner
J. Duling
R. C. Durfee
T.O. Early
J. M. Forstrom
M.W. Francis
D. $\dot{W}$. Frazier
C. D. Goins, Jr.
J. Goodbred
D. R. Guminski
C. S. Haase
D. D. Herr
D. A. Hill
J. Johnson
J. B. Johnson
V. W. Jones
D.T. Kendall
R. M. Keyser
B. L. Kimmel
R. H. Kingrea
C. R. Kirkpatrick
S. Y. Lee
R. C. Mason
J. C. Massey
T. W. Morris
M. E. Musolf
J. E. Powell
R. Richmond
J. G. Rogers
R. H. Snyder
P. A. Sperling
C. Stair
L. C. Stenzel
W. D. Strunk
F. J. Sweeney
H. Sydnor
T. D. Taylor
S. Turner
W. Walker
D. S. Wattier
DOE/PORTS Site Office
E. C. Document Center
PGDP Library
PORTS Library
Portsmouth Environmental Compliance-RC
Portsmouth Records Management

\section{External Distribution}

Department of Energy Information Center, 505 West Emmitt Ave., Waverly, Ohio 45690

Office of Assistant Manager for Energy Research and Development. U.S. Department of Energy Oak Ridge Operations, P.O. Box 2001, Oak Ridge, TN 37831-8600.

Office of Scientific and Technical Information, P.O. Box 62, Oak Ridge, TN 37831

This report is distributed widely by the Department of Energy's Oak Ridge Operations Office to local, state and federal government agencies; Congress; the public; and the news media. 


\section{Conversions}

\begin{tabular}{|c|c|c|}
\hline Multiply & by & to obtain \\
\hline in. & 2.54 & $\mathrm{~cm}$ \\
\hline $\mathrm{ft}$ & 0.305 & $\mathrm{~m}$ \\
\hline $\mathrm{mi}$ & 1.61 & $\mathrm{~km}$ \\
\hline lb & 0.4536 & $\mathrm{~kg}$ \\
\hline liq qt (U.S.) & 0.946 & $\mathrm{~L}$ \\
\hline $\mathrm{ft}^{2}$ & 0.093 & $\mathrm{~m}^{2}$ \\
\hline $\mathrm{mi}^{2}$ & 259 & $\mathrm{~km}^{2}$ \\
\hline $\mathrm{f}^{3}$ & 0.028 & $\mathrm{~m}^{3}$ \\
\hline $\mathrm{dpm}$ & 0.45 & $\mathrm{pCi}$ \\
\hline $\mathrm{pCi}$ & $10^{-6}$ & $\mathrm{Ci}$ \\
\hline $\mathrm{pCil}$ (water) & $10^{-9}$ & Cinl (water) \\
\hline $\mathrm{pCi} / \mathrm{m}^{3}$ (air) & $10^{-12}$ & $\mathrm{Ci} / \mathrm{mL}$ (air) \\
\hline $\mathrm{cm}$ & 0.394 & in. \\
\hline $\mathbf{m}$ & 3.28 & $\mathrm{ft}$ \\
\hline $\mathrm{km}$ & 0.621 & $\mathrm{mi}$ \\
\hline $\mathbf{k g}$ & 2.205 & b \\
\hline $\mathrm{L}$ & 1.057 & liq qt (U.S.) \\
\hline $\mathrm{m}^{2}$ & 10.764 & $\mathrm{ft}^{2}$ \\
\hline $\mathrm{km}^{2}$ & 0.386 & $\mathrm{mi}^{2}$ \\
\hline $\mathrm{m}^{3}$ & 35.31 & $\mathrm{f}^{3}$ \\
\hline $\mathrm{pCi}$ & 2.22 & $\mathrm{dpm}$ \\
\hline uCi & $10^{6}$ & $\mathrm{pCi}$ \\
\hline u Ci/mL (water) & $10^{9}$ & pCin (water) \\
\hline u Ci/mL (air) & $10^{12}$ & $\mathrm{pCi} \mathrm{m}^{3}$ (air) \\
\hline ha & 2.47 & acre \\
\hline
\end{tabular}

